NUREG/CR-5584

ORNL/TM-11575

RF

\title{
Results of Crack-Arrest Tests on Two Irradiated High-Copper Welds
}

Manuscript Completed: October 1990

Datc Published: December 1990

Prepared by

S. K. Iskander, W. R. Corwin, R. K. Nanstead

Oak Ridge National Laboratory

Operated by Martin Marietta Energy Systems, Inc.

Oak Ridge National Laboratory

Oak Ridge, TN 37831-6285

Prepared for

Division of Engineering

Office of Nuclear Regulatory Research

U.S. Nuclear Regulatory Commission

Washington, DC 20555

NRC FIN L1098

Under Contract No. DE-ACO5-84OR21400 
LIST OF TABLES . . . . . . . . . . . . . . . . . . . . . . . . . v

LIST OF FIGURES . . . . . . . . . . . . . . . . . . . . . . . . . vii

NOMENCLATURE . . . . . . . . . . . . . . . . . . . . . ix

FOREWORD . . . . . . . . . . . . . . . . . . . . . . . $\times 1$

ABSTRACT . . . . . . . . . . . . . . . . . . . . . . . . 1

1. INTRODUCTION . . . . . . . . . . . . . . . . . . . . . . . . . 2

2. DESCRIPTION OF MATERIALS AND PROCEDURES . . . . . . . . . . . 3

2.1 Testing Procedures . . . . . . . . . . . . . . . . . . . . 3

2.2 Analysis Procedures . . . . . . . . . . . . . . . . 12

3. RESULTS AND DISCUSSION . . . . . . . . . . . . . . . . . . . . 18

4. COMPARISON WITH OTHER DATA... . . . . . . . . . . . . . 36

5. SUMMARY . . . . . . . . . . . . . . . . . . . . . . . . . 37

6. ACKNOWLEDGMENTS . . . . . . . . . . . . . . . . . . . 38

REFERENCES . . . . . . . . . . . . . . . . . . . . . . . . . . 39

APPENDIX A: Detailed Crack-Arrest Specimen Data and

Test Results.............. . . . 41

APPENDIX B. Listing of Basic Computer Code CA_TEST . . . . . . 63

APPENDIX C. Young's Modulus used in the Evaluation of the Crack-Arrest Data . . . . . . . . . . . 77

APPENDIX D. Typical Output From CA_TEST for a Weldembrittled and Duplex Specimen . . . . . . . . . . 81

APPENDIX E. Strip Charts and Fracture Surfaces . . . . . . . . 87 


\section{LIST OF TABLES}

Page

1. Chemical composition of the two submerged-arc welds in

the HSSI Fifth and Sixth Irradiation Series . . . . . . . . . 5

2. Irradiated crack-arrest specimen complement for each of the $72 \mathrm{~W}$ and $73 \mathrm{~W}$ weldments. . . . . . . . . . . . 5

3. Nominal dimensions of weld-embrittled crackarrest specimens used in the Sixth Irradiation Series . . . . . . . . . . . . . . . . 7

4. Estimate of the average relative error in $f(x)$ (and thus in $\mathrm{K}_{\mathrm{a}}$ ) due to errors in the determination of initial and final crack lengths $x=a_{0} / W=0.33$ and $x=a_{a} / W-0.85$, respectively, for the various specimen sizes . . . . . . . . . . . . . 16

5. Summary of the irradiation temperature and fluence for Series $72 \mathrm{~W}$ and $73 \mathrm{~W}$ crack-arrest specimens . . . . . . . . 19

6. Initial, adjusted, and normalized reference temperatures $\mathrm{RT}_{\mathrm{NDT}}$ for the $72 \mathrm{~W}$ and $73 \mathrm{~W}$ weldments . . . . . 22

7. Unirradiated crack-arrest toughness data obtained

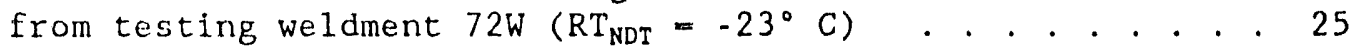

8. Unirradiated crack-arrest toughness data obtained from testing weldment $73 \mathrm{~W}\left(\mathrm{RT}_{\mathrm{NDT}}=-34^{\circ} \mathrm{C}\right)$. . . . . . . . . 27

9. Irradiated crack-arrest toughness data for the weld-embrittled type specimens from weld $72 \mathrm{~W}$ (normalized $\mathrm{RT}_{\mathrm{NDT}}=57^{\circ} \mathrm{C}$ ) . . . . . . . . . . . . . . . 29

10. Irradiated crack-arrest toughness data for the weld-embrittled type specimens from weld $73 \mathrm{~W}$ (normalized $\mathrm{RT}_{\mathrm{NDT}}=59^{\circ} \mathrm{C}$ ) . . . . . . . . . . . . . . . 30

A.1. Measured dimensions in millimeters of the unirradiated crack-arrest specimens from the $72 \mathrm{~W}$ and $73 \mathrm{~W}$ weldments . . . . . . . . . . . . . .

A.2. Measured dimensions in millimeters of the irradiated weld-embrittled crack-arrest specimens from the $72 \mathrm{~W}$ and $73 \mathrm{~W}$ weldments . . . . . . . . . . 50

A. 3. Postest values measured for unirradiated crack-arrest specimens from the $72 \mathrm{~W}$ and $73 \mathrm{~W}$ weldments. . . . 52 
A.4. Posttest values measured for irradiated

crack-arrest specimens from the $72 \mathrm{~W}$ and $73 \mathrm{~W}$ weldments . . . 55

A.5. Values measured during crack-arrest testing of the unirradiated weldments $72 \mathrm{~W}$ and $73 \mathrm{~W}$. . . . . . . . . . 56

A.6. Values measured during crack-arrest testing

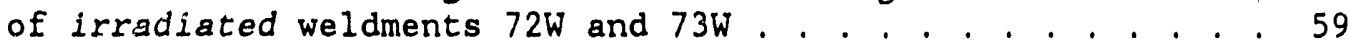

C.1. Comparison of Young's modulus calculated using values given in the ASME Code and Eq. (C.1) . . . . . . . . . 77 


\section{LIST OF FIGURES}

Page

1. Cross section of typical submerged-arc weld used in the $72 \mathrm{~W}$ and $73 \mathrm{~W}$ welds used in the Fifth and Sixth Irradiation Series . . . . . . . . . . . . . . . . . 4

2. Nominal dimensions in millimeters of weld-embrittled crack-arrest specimens used in the Sixth Irradiation Series . . . . . . . . . . . . . . . . . . . . . 6

3. Schematic drawing of equipment used to perform crackarrest testing of irradiated specimens before set-up in the hot-cell $500-\mathrm{kN}$ testing machine . . . . . . . . . 8

4. Photograph of equipment used to perform crack-arrest testing of irradiated specimens before set-up in the hot-cell. $500-\mathrm{kN}$ testing machine . . . . . . . . . . 9

5. Closeup view of the environmental chamber used for temperature conditioning of the crack-arrest specimens after installation in the hot-cell 500-kN tensile testing machine .. . . . . . . . . . . . . 11

6. General view of the test system as it is being prepared for a crack-arrest test . . . . . . . . . . . . . . 11

7. Chart produced on an X-Y plotter during a typical crack-arrest test of an irradiated specimen . . . . . . . . . 13

8. Photograph taken through a Kollmorgen periscope of the fracture surfaces of two typical crackarrest specimens after heat-tinting and splitting them open. The 2- or 3-mm, darker, transverse strips near the initial crack front are the brittle crack-starter weld beads . . . . . . . . . . . . . . . . . . 14

9. Calibration function for crack arrest specimens as given in ASTM E 1221-88 . . . . . . . . . . . . . . . . . 17

10. Distribution of fluence in the 18 irradiated weldembrittled-type crack specimens tested from the $72 \mathrm{~W}$ weld

11. Distribution of fluence in the 17 irradiated crack specimens of the $73 \mathrm{~W}$ weld that were tested successfully 
12. Yield and ultimate strengths vs test temperature for weld $72 \mathrm{~W}$ (a) unirradiated and (b) irradiated at a nominal temperature of $288^{\circ} \mathrm{C}$ to $1.57 \times 10^{19}$ neutrons $/ \mathrm{cm}^{2}(>1 \mathrm{MeV})$. . . . . . . . . . . .

13. Yield and ultimate strengths vs test temperature for weld $73 \mathrm{~W}$ (a) unirradiated and (b) irradiated at a nominal temperature of $288^{\circ} \mathrm{C}$ to $1.56 \times 10^{19}$ neutrons $/ \mathrm{cm}^{2}(>1 \mathrm{MeV})$. . . . . . . . . . . . . . 21

14. Charpy $V$-notch-impact energy vs test temperature for welds $72 \mathrm{~W}$ and $73 \mathrm{~W}$ (a) unirradiated (b) irradiated at a nominal temperature of $288^{\circ} \mathrm{C}$ to $1.51 \times 10^{19}$ neutrons $/ \mathrm{cm}^{2}(>1 \mathrm{MeV})$. . . . . . . . . . . . . . 23

15. Detailed crack-arrest toughness $K_{a}$ vs test temperature for the unirradiated $72 \mathrm{~W}$ weld showing the different specimen sizes and types used

16. Detailed crack-arrest toughness $K_{a}$ vs test temperature for the unirradiated $73 \mathrm{~W}$ weld showing the different specimen sizes and types used... . . . . . . . . . . . . . 32

17. Detailed crack-arrest toughness $K_{a}$ vs test temperature for the irradiated $72 \mathrm{~W}$ weld showing the different specimen sizes and types used . . . . . . . . . . . . . . . . 33

18. Detailed crack-arrest toughness $\mathrm{K}_{\mathrm{a}}$ vs test temperature for the irradiated $73 \mathrm{~W}$ weld showing the different specimen sizes and types used. . . . . . . . . . . . . . . . 33

19. Unirradiated and irradiated crack-arrest toughness $K_{a}$ vs test temperature for the $72 \mathrm{~W}$ weld. . . . . . . . . . . 34

20. Unirradiated and irradiated crack-arrest toughness $\mathrm{K}_{\mathrm{a}}$ vs test temperature for the $73 \mathrm{~W}$ weld.......... . 34

21. All crack-arrest toughness $K_{a}$ data for welds $72 \mathrm{~W}$ and $73 \mathrm{~W}$ plotted as a function of ( $\mathrm{T}-\mathrm{RT}_{\mathrm{NDT}}$ )

A.1. Comparison of values of Young's moduli as calculated from an American Society of Mechanical Engineers table and an Electric Power Research Institute expression 


\section{NOMENCLATURE}

\section{ACRONYMS}

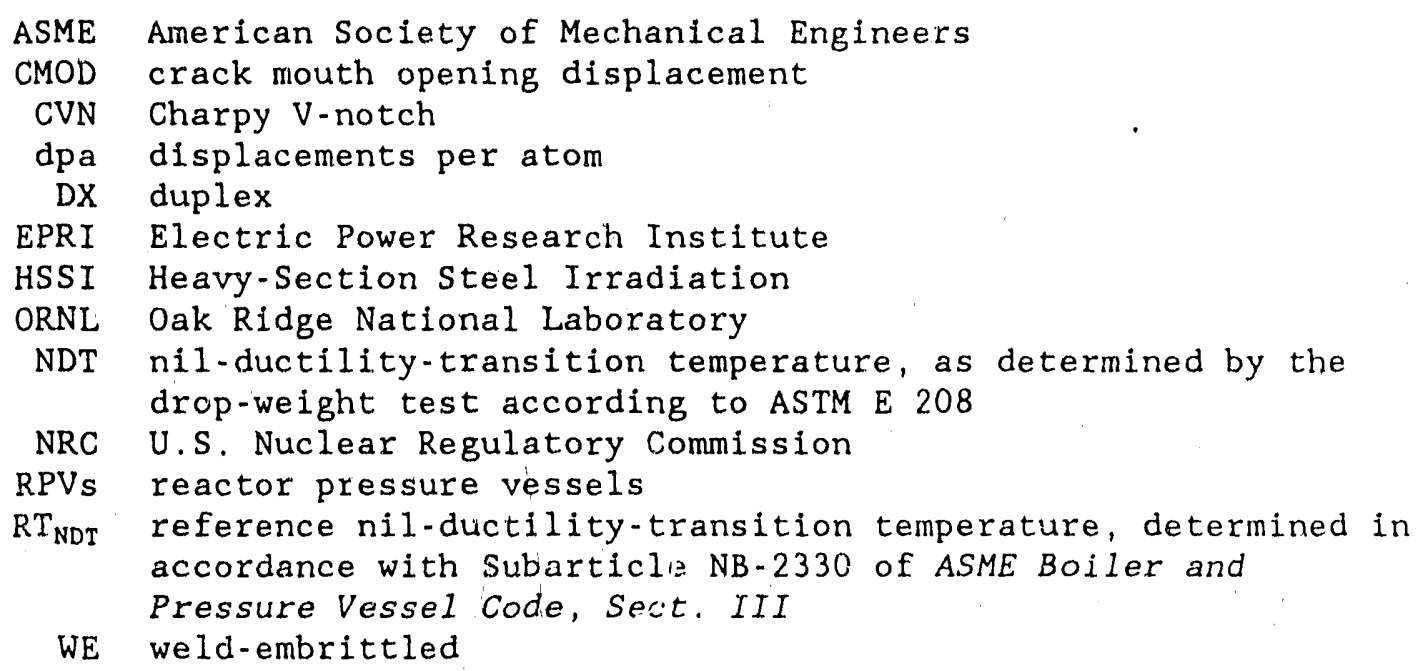

\section{SYMBOLS}

a initial slot length $a_{o}$ or final crack length $a_{a}$

$a_{a}$ arrested crack length

$a_{0}$ initial slot length

B specimen thickness (Fig. 2)

$B_{\mathrm{N}}$ specimen thickness at crack plane (Fig. 2)

D split-pin hole diameter (Fig. 2)

$\delta$ crack mouth opening displacement

$\Delta \mathrm{TT}_{41-\mathrm{J}}$ shift in the $41-\mathrm{J}$ CVN-impact energy leve1

E Young's modulus

$f(x)$ crack-arrest specimen calibration function [Eq. (2)]

$\phi$ fluence, neutrons $/ \mathrm{cm}^{2}$

$2 \mathrm{H}$ specimen height (Fig. 2)

$\mathrm{K}_{\mathrm{a}}$ value of the stress intensity factor shortly after arrest*

$k_{o}$ value of the stress intensity factor at crack initiation

$K_{I}$ stress intensity factor

$K_{I a}$ value of the crack-arrest fracture toughness $K_{a}$ for a crack that arrests under conditions of crack front plane-strain*

$\mathrm{K}_{\mathrm{Ic}}$ plane-strain fracture toughness

$\mathrm{K}_{\mathrm{Jc}}$ a measure of fracture toughness calculated from the $\mathrm{J}$-integral $\mathrm{J}_{0}$ at the point of cleavage using the relationship $\left(K_{\mathrm{Jc}}\right)^{2}=\mathrm{EJ}_{\mathrm{C}}$

$K_{0}$ value of the stress intensity factor at crack initiation

L, $L^{\prime} \quad$ (See Fig. 2)

\footnotetext{
*Excerpted from ASTM E $1221-88$.
} 


\section{SYABOLS}

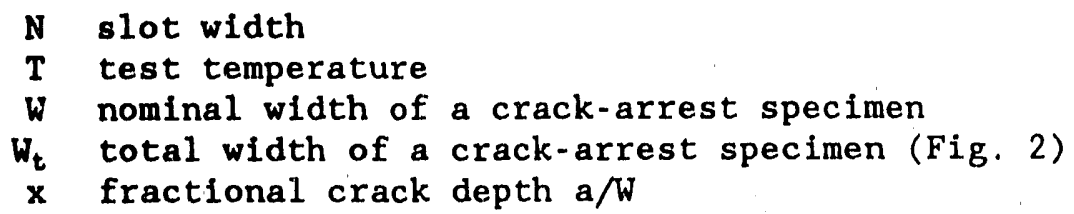




\section{FOREWORD}

The work reported here was performed at Oak Ridge National Laboratory (ORNL) under the Heavy-Section steel Irradiation (HSSI) Program, W. R. Corwin, Program Manager. The program is sponsored by the Office of Nuclear Regulatory Research of the U.S. Nuclear Regulatory Commission (NRC). The technical monitor for the NRC is A. Taboada.

This report is designated HSSI Report 3. Reports in this series are 11sted below:

1. F. M. Haggag, W. R. Corwin, and R. K. Nanstad, Martin Marietta Energy systems, Inc., Oak Ridge Nat1. Lab., Oak Ridge, Tenn., Irradiation Effects on Strength and Toughness of Three-Wire Series-Arc Stainless Steel Weld Overlay Cladding, NUREG/CR-5511 (ORNL/TM-11439), December. 1989.

2. L. F. Miller, C. D. Baldwin, F. W. Stallman, and F. B. K. Kom, Martin Marietta Energy Systems, Inc., Oak Ridge Nat] Lab., Oak Ridge, Tenn., Neutron Exposure Parameters for the Metallurgical Test Specimens in The Sixth Heavy-Section Steel Irradiation Series, NUREG/CR-5409 (ORNL/TM-11267), May 1990.

\section{This report.}

The HSSI Program includes both follow-on and the direct continuation of work that was performed under the Heavy-Section Steel Technology (HSST) Program. Previous HSST reports related to irradiation effects in pressure vessel materials and those containing unirradiated properties of materials used in HSSI and HSST irradiation programs are tabulated below as a convenience to reader.

C. E. Childress, Union Carbide Corp. Nuclear Div., Oak Ridge Natl. Lab., Oak Ridge, Tenn., Fabrication History of the First Two 12-in. -Thick A-533 Grade B, Class 1 Steel Plates of the Heavy Section Steel Technology Program, ORNL-4313, February 1969.

T. R. Mager and F. O. Thomas, Westinghouse Electric Corperation, PWR Systems Division, Pittsburgh, Pa., Evaluation by Linear Elastic Fracture Mechanics of Radiation Damage to Pressure Vessel Steels, WCAP-7328 (Rev.), October 1969.

P. N. Randa11, TRW Systems Group, Redondo Beach, Calif., Gross Strain Measure of Fracture Toughness of Steels, HSSTP-TR-3, Nov. 1, 1969.

L. W. Loeche1, Martin Marietta Corporation, Denver, Colo., The Effect of Testing Variables on the Transition Temperature in Steel, MCR-69-189, Nov. 20, 1969. 
W. O. Shabbits, W. H. Pryle, and E. T. Wessel, Westinghouse Electric Corporation, PWR Systems Division, Pittsburgh, Pa, , Heavy-Section Fracture Toughness Properties of A533 Grade B Class 1 steel Plate and Submerged Arc Weldment, WCAP-7414, December 1969.

C. E. Childress, Union Carbide Corp. Nuclear Div, , Oak Ridge Nat1. Lab., Oak Ridge, Tenn., Fabrication History of the Third and Fourth ASTM A-533 Steel Plates of the Heavy Section Steel Technology Program, ORNL 4313-2, February 1970.

P. B. Crosley and E. J. Ripling, Materials Research Laboratory, Inc., Glenwood, IIl., Crack Arrest Fracture Toughness of A533 Grade B Class 1 Pressure Vesse1 Stee1, HSSTP-TR-8, March 1970.

F. J. Loss, Naval Research Laboratory, Washington, D.C., Dynamic Tear Test Investigations of the Fracture Toughness of Thick-Section Stee1, NRL-7056, May 14, 1970.

T. R. Mager, Westinghouse Electric Corporation, PWR Systems Div., Pittsburgh, Pa., Post-Irradiation Testing of $2 T$ Compact Tension Specimens, WCAP-7561, August 1970.

F. J. Witt and R. G. Berggren, Union Carbide Corp. Nuclear Div., Oak Ridge National Laboratory, Oak Ridge, Tenn., Size Effects and Energy Disposition in Impact Specimen Testing of ASTM A533 Grade B Steel, ORNL/TM-3030, August 1970.

D. A. Canonico, Union Carbide Corp. Nuclear Div., Oak Ridge National Laboratory, Oak Ridge, Tenn., Transition Temperature Considerations for Thick-Wall Nuclear Pressure Vesse1s, ORNL/TM-3114, October 1970.

T. R. Mager, Westinghouse Electric Corporation, PWR Systems Div., Pittsburgh, Pa., Fracture Toughness Characterization Study of A533, Grade B, Class 1 Stee1, WCAP-7578, October 1970 .

W. 0. Shabbits, Westinghouse Electric Corp., PWR Systems Div., Pittsburg., Pa., Dynamic Fracture Toughness Properties of Heavy Section A533 Grade B Class 1 Steel Ylate, WCAP-7623, December 1970.

C. E. Childress, Union Carbide Corp. Nuclear Div., Oak Ridge Nati. Lab. Oak Ridge, Tenn., Fabrication Procedures and Acceptance Data for ASTM A-533 Welds and a 10-in. -Thick ASTM A-543 Plate of the Heavy Section Steel Technology Program, ORNL-TM-4313-3, January 1971.

D. A. Canonico and R. G. Berggren, Union Carbide Corp. Nuclear Div., Oak Ridge Natl. Lab., Oak Ridge, Tenn., Tensile and Impact Properties of Thick-Section Plaise and Weldments, ORNL/TM-3211, January 1971.

C. W. Hunter and J. A. Williams, Hanford Eng. Dev. Lab., Richland, Wash., Fracture and Tensile Behavior of Neutron-Irradiated A533-B Pressure Vessel Stee1, HEDL-TME-71-76, February 6, 1971. 
C. E. Childress, Union Carbide Corp. Nuclear Div., Oak Ridge Natl. Lab., Oak Ridge, Tenn., Manual for ASTM A533 Grade B Class 1 Steel (HSST Plate 03) Provided to the International Atomic Energy Agency, ORNL/TM-3193, March 1971.

P. N. Randa11, TRW Systems Group, Redondo Beach, Calif., Gross Strain Crack Tolerance of A533-B Stee1, HSSTP-TR-14, May 1, 1971.

C. L. Segaser, Union Carbide Corp. Nuclear Div., Oak Ridge Nat1. Lab., Oak Ridge, Tenn., Feasibility Study, Irradiation of Heavy-Section Steel Specimens in the South Test Facility of the Oak Ridge Research Reactor, ORNL/TM-3234, May 1971.

H. T. Corten and R. H. Sallors, University of Illinois, Urbana, I11., Relationship Between Material Fracture Toughness Using Fracture Mechanics and Transition Temperature Tests, T\&AM Report 346. August 1, 1971 .

L. A. James and J. A. Williams, Hanford Eng. Dev. Lab., Richland, Wash., Heavy Section Steel Technology Program Technical Report No. 21. The Effect of Itmperature and Neutron Irradiation Upon the Fatigue-Crack Propagation Behavior of ASTM A533 Grade B, Class 1 Steel, HEDL-TME 72-132, September 1972.

P. B. Crosley and E. J. Ripling, Materials Research Laboratory, Inc., Glenwood, I11., Crack Arrest in an Increasing K-Field, HSSTP-TR-27, January 1973.

W. J. Stelzman and R. G. Berggren, Union Carbide Corp. Nuclear Div., Oak Ridge Natl. Lab., Oak Ridge, Tenn., Radiation Strengthening and Embrittlement in Heavy-Section Steel Plates and Welds, ORNL-4871, June 1973.

J. M. Steichen and J. A. Williams, Hanford Eng. Dev. Lab., Richland, Wash., High Strain Rate Tensile Properties of Irradiated ASTM A533 Grade B Class 1 Pressure Vessel Stee1, HEDL-TME 73-74, July 1973.

J. A. Williams, Hanford Eng. Dev. Lab., Richland, Wash., The Irradiation and Temperature Dependence of Tensile and Fracture Properties of ASTM A533, Grade B, Class 1 Steel Plate and Weldment, HEDL-TME 73-75, August 1973 .

J. A. Williams, Hanford Eng. Dev. Lab., Richland, Wash., Some Comments Related to the Effect of Rave on the Fracture Toughness of Irradiated ASTM A553-B Steel Based on Yield Strength Behavior, HEDL-SA 797, December 1974.

J. A. Williams, Hanford Eng. Dev. Lab., Richland, Wash., The Irradiated Fracture Toughness of ASTM A533, Gracie B, Class 1 Steel Measured with a Four-Inch-Thick Compact Tension Specimen, HEDL-TME 75-10, January 1975. 
J. G. Merkle, G. D. Whitman, and R. H. Bryan, Union Carbide Corp. Nuclear Div., Oak Ridge Nat1. Lab., Oak Ridge, Tenn., An Evaluation of the HSST Program Intermediate Pressure Vessel Tests in Terms of LightWater-Reactor Pressure Vessel Safety, ORNL/TM-5090, November 1975.

J. A. Davidson, L. J. Ceschini, R. P. Shogan; and G. V. Rao, Westinghouse Electric Corporation, Pittsburgh, $\mathrm{Pa}$, , The Irradiated Dynamic Fracture Toughness of ASTM A533, Grade B, Class 1 Steel Plate and Submerged ArC Weldment, WCAP-8775, October 1976.

J. A. Williams, Hanford Eng, Dev. Lab., Richland, Wash., Tensile Properties of Irradiated and Unirradiated Welds of A533 Steel Plate and A508 Forgings, NUREG/CR-1158 (ORNL/SUB-79/50917/2), July 1979.

J. A. Williams, Hanford Eng. Dev. Lab., Richland, Wash., The Ductile Fracture Toughness of Heavy Section Steel Plate, NUREG/CR-0859, September 1979.

K. W. Carlson and J. A. Williams, Hanford Eng. Dev. Lab., Richland, Wash., The Effect of Crack Length and Side Grooves on the Ductile Fracture Toughness Properties of ASTM A533 Stee1, NUREG/CR-1171 (ORNL/SUB - 79/50917/3), October 1979.

G. A. Clarke, Westinghouse Electric Corp., Pittsburgh, Pa., An Evaluation of the Unloading Compliance Procedure for J-Integral Testing in the Hot Cell, Final Report, NUREG/CR-1070 (ORNL/Sub-7394/1), October 1979.

P. B. Crosley and E. J. Ripling, Materials Research Laboratory, Inc., Glenwood, I11., Development of a Standard Test for Measuring $K_{I a}$ with a Modified Compact Specimen, NUREG/CR-2294 (ORNL/SUB-81/7755/1), August 1981.

H. A. Domian, Babcock and Wilcox Company, Alliance, Ohio, Vessel V-8 Repair and Preparation of Low jpper-Shelf Weldment, NUREG/CR-2676 (ORNL/Sub/81-85813/1), June 1982.

R. D. Cheverton, S. K. Iskander, and D. G. Ball, Union Carbide Corp. Nuclear Div, , Oak Ridge Natl. Lab., Oak Ridge, Tenn., PWR Pressure Vessel Integrity Duing Overcooling Accidents: A Parametric Analysis, NUREG/CR-2895 (ORNL/TM-7931), February 1983.

J. G. Merkle, Union Carbide Corp. Nuclear Div., Dak Ridge Natl. Lab., Oak Ridge, Tenn., An Examination of the Size Effects and Data Scatter Observed in Smal1 Specimen Cleavage Fracture Toughness Testing, NUREG/CR-3672 (ORNL/TM-9088), April 1984.

W. R. Corwin, Martin Marietta Energy Systems, Inc., Oak Ridge Nat1. Lab., Oak Ridge, Tenn., Assessment of Radiation Effects Relating to Reactor Pressure Vessel Cladding, NUREG/CR-3671 (ORNL-5047), July 1984. 
W. R. Corwin, R. G. Berggren, and R. K. Nanstad, Martin Marletta Energy Systems, Inc., Oak Ridge Natl. Lab., Oak Kidge, Tenn., Charpy Toughness and Tensile Properties of a Neutron Irradiared Stainless Steel Submerged-Arc Weld Cladding Overlay, NUREG/CR-3927 (ORNL/TM-9709), September 1984.

J. J. McGowan, Martin Marietta Energy Systems, Ine., Oak Ridge Nat1. Lab., Oak Ridge, Tenn., Tensile Properties of Irradiated Nuclear Grade Pressure Vessel Plate and Welds for the Fourth HSST Irradiation Series, NUREG/CR-3978 (ORNL/TM-9516), January 1985.

J. J. McGowan, Martin Marietta Energy Systems, Inc., Oak Ridge Nat1. Lab., Oak Ridge, Tenn., Tensile Properties of Irradiated Nuclear Grade Pressure Vessel Welds for the Third HSST Irradiation Series, NUREG/CR-4086 (ORNL/TM-9477), March 1985.

W. R. Corwin, G. C. Robinson, R. K. Nanstad, J. G. Merkle, R. G. Berggren, G. M. Goodwin, R. L. Swain, and T. D. Owings, Martin Marietta Energy Systems, Inc., Oak Ridge Natl. Lab., Oak Ridge, Tenn., Effects of Stainless Steel Weld Overlay Cladding on the Structural Integrity of Flawed Steel Plates in Bending, Series 1, NUREG/CR-4015 (ORNL/TM-9390), April 1985.

W. J. Stelzman, R. G. Berggren, and T. N. Jones, Martin Maxietta Energy Systems, Inc., Oak Ridge Nat1. Lab., Oak Ridge, Tenn., ORNL Characterization of Heavy-Section Steel Technology Program Plates 01, 02, and 03, NUREG/CR-4092 (ORNL/TM-9491), April 1985.

G. D. Whitman, Martin Marietta Energy Systems, Inc., Oak Ridge Natl. Lab., Oak Ridge, Tenn., Historical Summary of the Heavy-Section Steel Technology Program and Some Related Activities ir Light-Water Reactor Pressure Vessel Safety Research, NUREG/CR-4489 (ORIL-6259), March 1986.

R. H. Bryan, B. R. Bass, S. E. Bolt, J. W. Bryson, J. G. Merkle, R. K. Nanstad, and G. C. Robinson, Martin Marietta Energy Systems, Inc., Oak Ridge Natl. Lab., Oak Ridge, Tenn,, Test of 6-in.-Thick Pressure Vessels. Series 3: Intermediate Test Vessel V-8A - Tearing Behavior of Low Upper-Shelf Material, NUREG-CR-4760 (ORNL-6187), May 1987.

D. B. Barker, R. Chona, W. L. Fourney, and G. R. Irwin, University of Maryland, College Park, Md., A Report on the Round Robin Program Conducted to Evaluate the Proposed ASTM Standard Test Method for Determining the Plane Strain Crack Arrest Fracture Toughness $\boldsymbol{K}_{I a}$, of Ferritic Materials, NUREG/CR-4966 (ORNL/Sub/79-7778/4), January 1988.

L. F. Miller, C. A. Baldwin, F. W. Stallman, and F. B. K, Kam, Martin Marietta Energy Systems, Inc., Oak Ridge Nat1. Lab., Oak Ridge, Tenn., Neutron Exposure Parameters for the Metallurgical Test Specimens in the Fifth Heavy-Section Steel Technology Irradiation Series Capsules, NUREG/CR-5019 (ORNL/TM-1058' '), March 1988. 
J. J. McGowan, R. K. Nanstad, and K. R. Thoms, Martin Marietta Energy Systems, Inc., Oak Ridge Nat1. Lab., Oak Ridge, Tenn., Characterization of Irradiated Current-Practice Welds and A533 Grade B Class 1 Plate for Nuclear Pressure Vessel Service, NUREG/CR-4880 (ORNL-6484/V1 and V2), July 1988.

R. D. Cheverton, W. E. Pennell, G. C. Robinson, and R. K. Nanstad, Martin Marietta Energy Systems, Oak Ridge Natl. Lab., Oak Ridge, Tenn., Impact of Radiation Embrittlement on Integrity of Pressure Vessel Supports for Two PWR Plants, NUREG/CR-5320 (ORNL/TM-10966), February 1989. 
S. K. Iskander

W. R. Corwin

R. K. Nanstad

The objective of this study was to determine the effect of neutron irradiation on the shift and shape of thi lower: bound curve to crack-arrest data. Two submerged-arc welds with copper contents of 0.23 and 0.31 wt 8 were commercially fabricated in $220-\mathrm{mm}$-thick plate. Crack-arrest specimens fabricated from these welds were irradiated at a nominal temperature of $288^{\circ} \mathrm{C}$ to an average fluence of $1.9 \times 10^{19}$ neutrons $/ \mathrm{cm}^{2}(>1 \mathrm{MeV})$. Evaluation of the results shows that the neutron-irradiation-induced crack-arrest toughness temperature shift is about the same as the Charpy V-notch impact temperature shift at the 41-J energy level. The shape of the lower-bound curves (for the range of test temperatures covered) dic iot seem to have been altered by irradiation compared to those of the ASME $K_{I a}$ curve.

${ }^{*}$ Research sponsored by the Office of Nuclear Regulatory Research, Division of Engineering Safety, U.S. Nuclear Regulatory Commission under Interage.ncy Agreement DOE 1886-8109-8L with the U.S. Department of Energy under contract DE-AC05-840R21400 with Martin Marietta Energy Systems, Inc. 


\section{INTRODUCTION}

In the fracture mechanics iategrity analysis of reactor pressure vessels (RPVs), the initiation and arrest fracture toughness curves as described in Sect. XI of ASME Boiler and Pressure Vessel Code are often used. These curves are used also for the normal operation of RPVs. The effects of neutron irradiation on toughness are accounted for by shifting the curves upward in temperature without change in shape by an amount equal to the temperature shift of the Charpy V-notch (CVN) impact energy curve at the $41-\mathrm{J}$ level $\left(\Delta \mathrm{TT}_{41-\mathrm{J}}\right)$. Such a procedure implies that the shifts in the fracture toughness curves are the same as that of the CVN $\Delta \mathrm{TT}_{41 \mathrm{~J}}$ and that irradiation does not change the shapes of the fracture toughness curves.

It is well known that irradiation of sorne RPV ferritic steels to fluences on the order of $2 \times 10^{19}$ neutrons $/ \mathrm{cm}^{2}(>1 \mathrm{MeV})$ can cause changes in the shape of the CVN impact energy curve. To determine whether similar changes in shape can occur in the fracture toughness curves, par.ticularly if such changes could lead to non-conservative determinations of the irradiated fracture toughness, research programs are sponsored by the U.S. Nuclear Regulatory Commission (NRC) within the Heavy-Section Steel Irradiation (HSSI) Program at Oak Ridge National Laboratory (ORNL).

Two of these programs are the Fifth and Sixth Irradiation Series. The objective of the Fifth Series was to determine the effect of neutron irradiation on the shift and shape of the $K_{I c} v s\left(T-R T_{N D T}\right)$ curve, where $\mathrm{K}_{\mathrm{Ic}}$ is the plane-strain fracture toughness, $\mathrm{T}$ is the temperature, and $\mathrm{RT}_{\mathrm{NDT}}$ is the reference nil-ductility-transition temperature. Although the objective is similar, the Sixth Series investigates the effect on $\mathrm{K}_{\mathrm{Ia}}$, the plane-strain crack-arrest fracture toughness. Both programs investigate the effects of irradiation on the fracture toughness of welds, since some pressure vessels in operation have welds with copper contents and end-oflife fluences which make them susceptible to severe degradation in toughness. The amount of experimental data on the effects of irradiation on crack-arrest fracture toughness is rather meager (Refs. [1] and [2]).

Two submerged-arc welds with copper contents of 0.23 and 0.31 wt 8 were commercially fabricated in $220-\mathrm{mm}$-thick plate. In the Fifth Irradiation Series, irradiated CVN impact, tensile, drop-weight, and compact specimens, made from the weldment were tested and the results are given in Refs. [3] and [4].

Crack-arrest specimens fabricated from these welds were irradiated at a nominal temperature of $288^{\circ} \mathrm{C}$ to an average fluence of $1.9 \times 10^{19}$ neutrons $/ \mathrm{cm}^{2}(>1 \mathrm{MeV})$. This report compares the results of crack-arrest tests on 36 irradiated weld-embrittled-type specimens with those from unirradiated control specimens. Since this is only the first phase of a two-phase program, the conclusions presented here are preliminary. 


\section{DESCRIPTION OF MATERIALS AND PROCEDURES}

The weld wire for both programs was produced commercially in one melt. The melt was split to allow for copper additions and resulted in two weld wires that were comparable in chemical composition except for copper. Several meters of weldment were commercially fabricated from each weld wire and were designated $72 \mathrm{~W}(0.23 \mathrm{wt} \& \mathrm{Cu})$ and $73 \mathrm{~W}(0.31 \mathrm{wt}$ $\& \mathrm{Cu})$. The welds were commercially fabricated in A 533, grade B, class 2 plate of $220-\mathrm{mm}$ ( 8 5/8-in.) thickness by using the submerged-arc weld process with one lot of Linde 0124 flux. A macrograph of weld $72 \mathrm{~W}$ is shown in Fig. 1, and the chemical compositions of both welds are given in Table 1. The welds were given a postweld heat treatment of $607^{\circ} \mathrm{C}$ for $40 \mathrm{~h}$, typical of that given commercial RPVs.

Two capsules, each containing 30 compact crack-arrest specimens of the two weldments, have been irradiated at a nominal temperature of $288^{\circ} \mathrm{C}$ to a fluence of approximately $1.9 \times 10^{19}$ neutrons $/ \mathrm{cm}^{2}(>1 \mathrm{MeV})$ in the Oak Ridge Research Reactor located at the ORNL. The irradiated specimen complement is given in Table 2, which gives the overall specimen dimensions. The complete nominal specimen dimensions are given in Fig. 2 and Table 3. For administrative purposes, the program was conducted in two phases. This report presents results of Phase 1 which consisted of crack-arrest tests on the 36 weld-embrittled-type specimens. In Phase 2 , the results from remaining 24 duplex-type crack-arrest specimens will be reported.

\subsection{Testing Procedures}

Testing was performed according to the ASTM "Test for Determining Plane-Strain Crack-Arrest Fracture Toughness, $\mathrm{K}_{\mathrm{Ia}}$, of Ferritic Steels" (E 1221-88). Crack-arrest testing of the irradiated specimens was performed in a hot cell by using a servohydraulic machine and the test chamber shown schematically in Fig. 3, and photcgraphically in Fig. 4. This equipment allows specimens to be tested with the split pins in either the so-called "normal" or "inverted" configuration at test temperatures ranging from -100 to $260^{\circ} \mathrm{C}$. * In the "normal" configuration, the lateral surfaces of the specimen are in contact with the test-machine platen and friction decreases the crack-driving force somewhat compared with the "inverted" configuration in which the specimen sits on the narrow shoulders of the split pin. The "inverted" configuration is used at testing temperatures above NDT. For further information on the "normal" and "Inverted" test configuration in crack-arrest testing, see Note 5 of ASTM E 1221-88.

*This temperature range was chosen during the design phase of the test chamber on the basis of the anticipated test temperature. The maximum temperature is limited by the Teflon ${ }^{\mathrm{m}}$ insert in the contact thermocouple. 


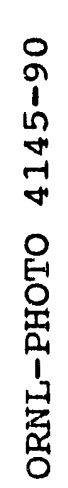

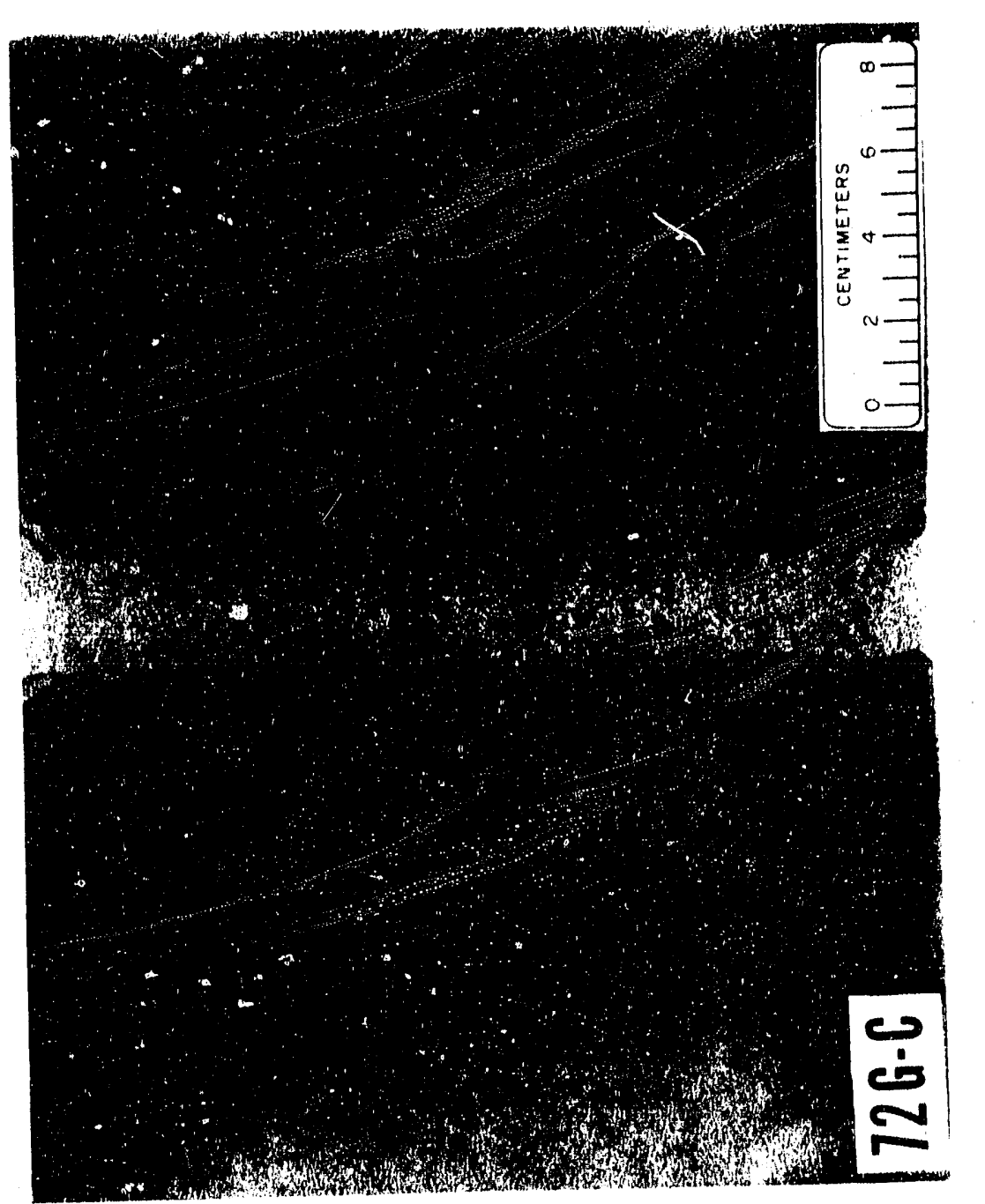

9 导

范出 C) 年 ऊิ 4 욤ำ 出 is

थ

\& 出 $r$ - -0 oo 被资 $N$ 总 
Table 1. Chemical composition of the two submerged-arc welds in the Fifth and Sixth Irradiation Series

\begin{tabular}{|c|c|c|c|c|c|c|c|c|c|c|}
\hline \multirow{2}{*}{ Materlal } & \multicolumn{10}{|c|}{ Composition (wt 8 ) } \\
\hline & C & Mn & $\mathbf{P}$ & S & Si. & $\mathrm{Cr}$ & $\mathrm{Ni}$ & Mo & $\mathrm{Cu}$ & $\mathrm{V}$ \\
\hline $72 W$ & 0.093 & 1.60 & 0.006 & 0.006 & 0.44 & 0.27 & 0.60 & 0.58 & 0.23 & 0.003 \\
\hline $73 W$ & 0.098 & 1.56 & 0.005 & 0.005 & $0.4 \%$ & 0.25 & 0.60 & 0.58 & 0.31 & 0.003 \\
\hline
\end{tabular}

Source: Values based on formula from R. K. Nanstad et al., "Effects of Irradiation on $\mathrm{K}_{\mathrm{Ic}}$ curves for High-Copper Welds," pp. 214-33 in Effects of Radiation on Material:, 14th International Symposium, ASTM STP 1046, Vol. II, ed. N. H. Packan, R. E. Stoller, and A. S. Kumar, American Society for Testing and Materials, Philadelphia, 1990.

Table 2. Irradated crack-arrest specimen complement for each of the $72 \mathrm{~W}$ and $73 \mathrm{~W}$ weldments

\begin{tabular}{lcc}
\hline Specimen type & $\begin{array}{c}\text { Dimensions } \\
(\mathrm{mm})\end{array}$ & $\begin{array}{c}\text { Quantity } \\
\text { per weld }\end{array}$ \\
\hline Weld embrittled & $25 \times 76 \times 76$ & 8 \\
Weld embrittled & $25 \times 152 \times 152$ & 7 \\
Weld embrittled & $33 \times 152 \times 152$ & 3 \\
Duplex & $33 \times 152 \times 152$ & 12 \\
\hline
\end{tabular}




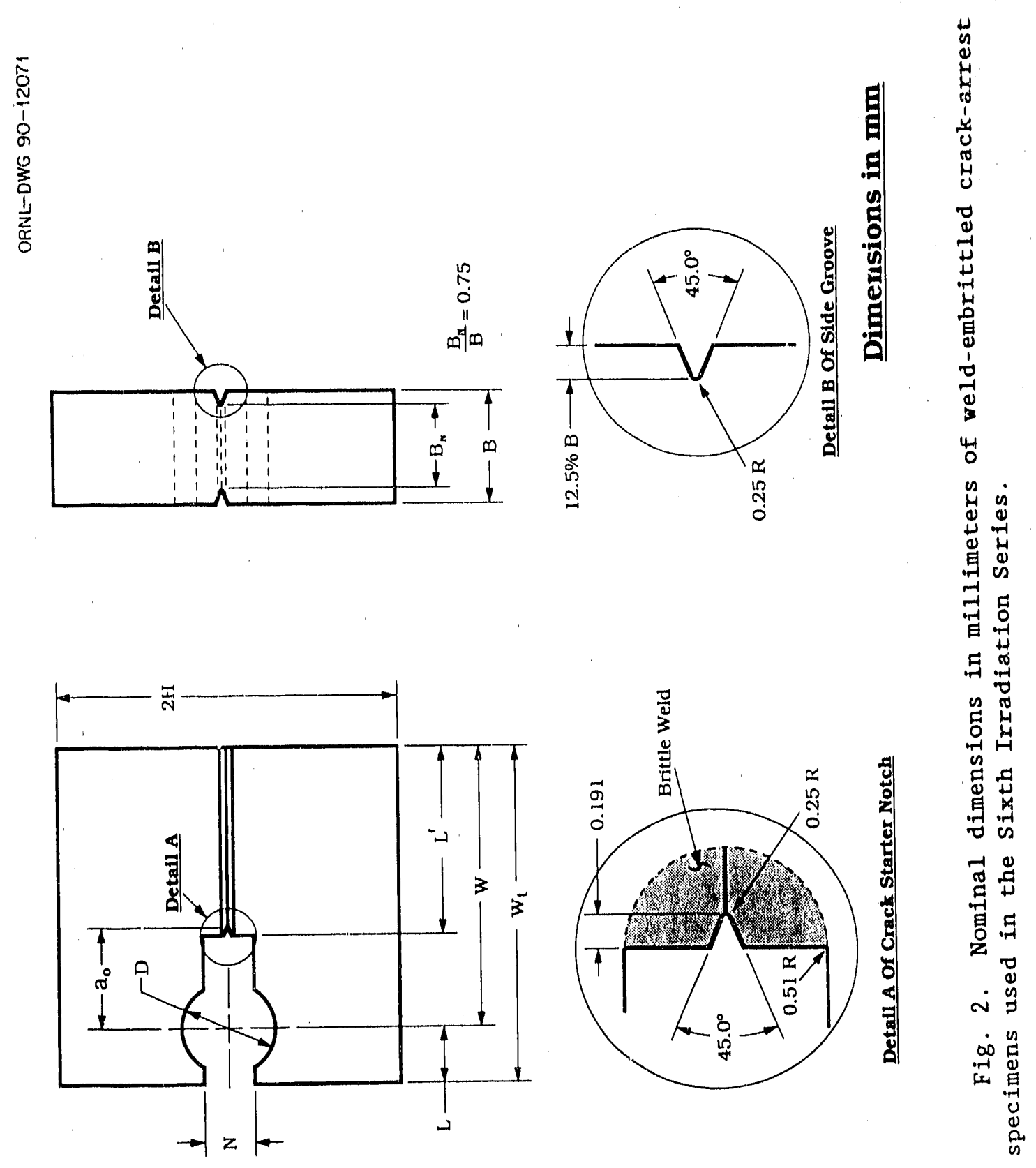




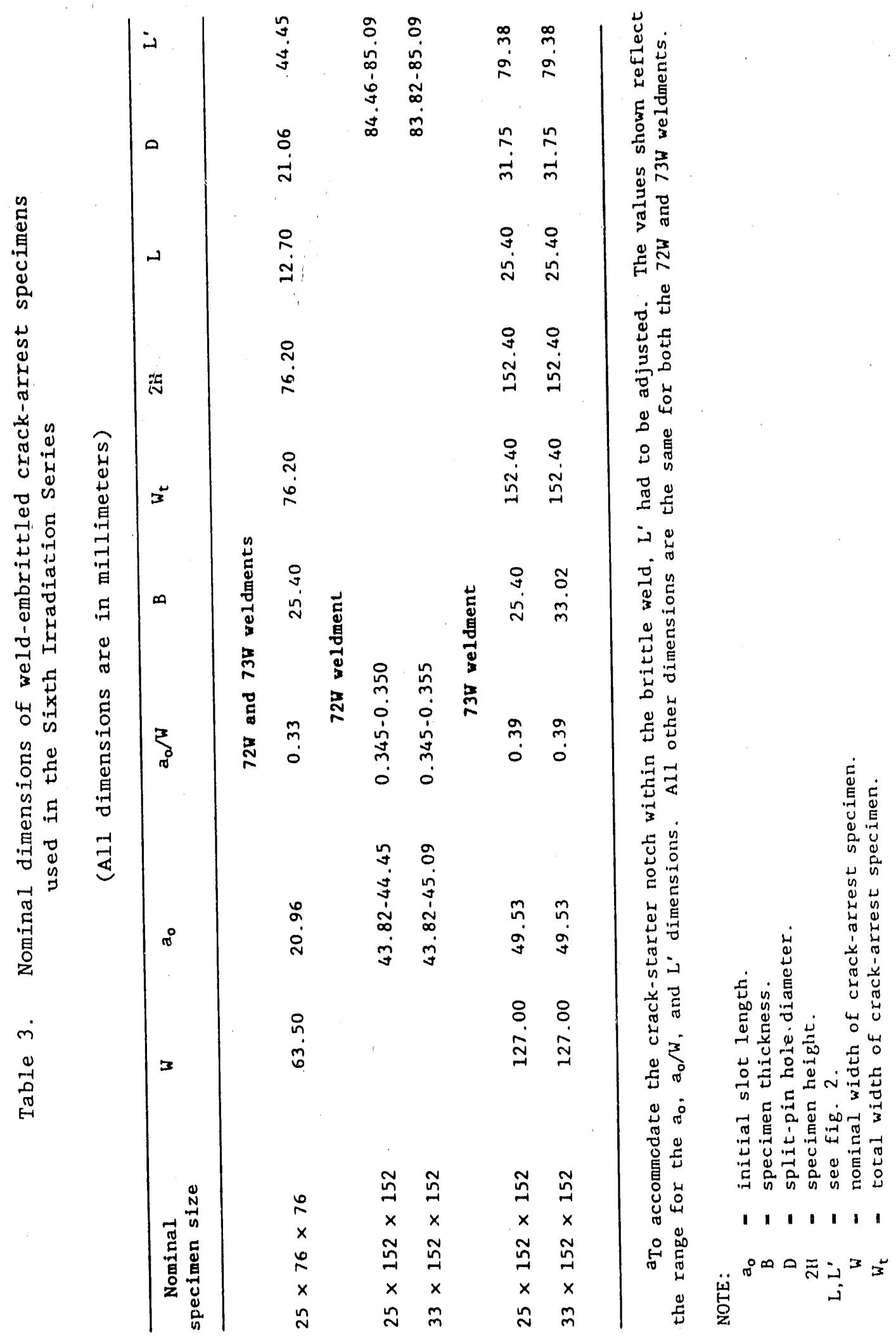




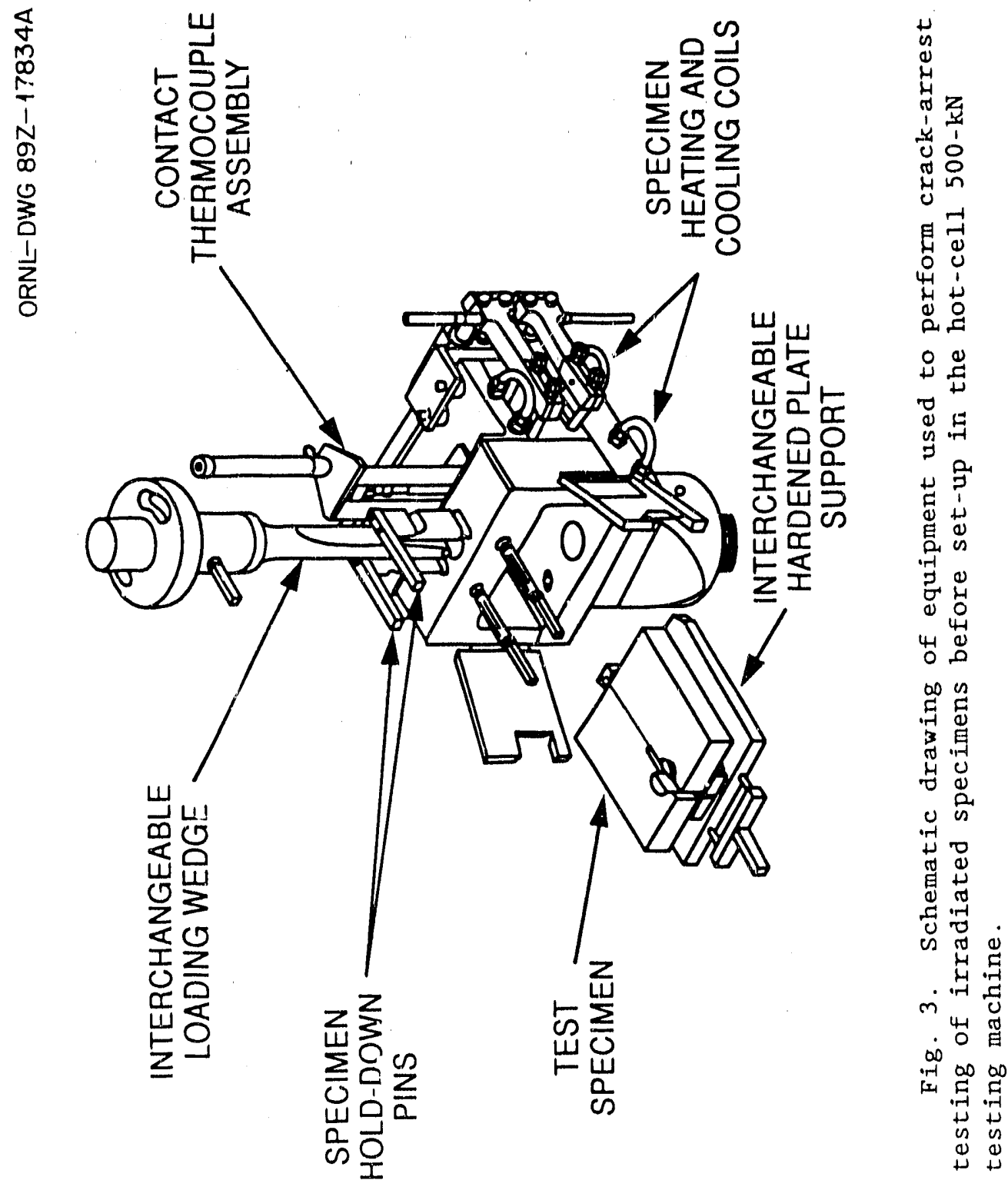




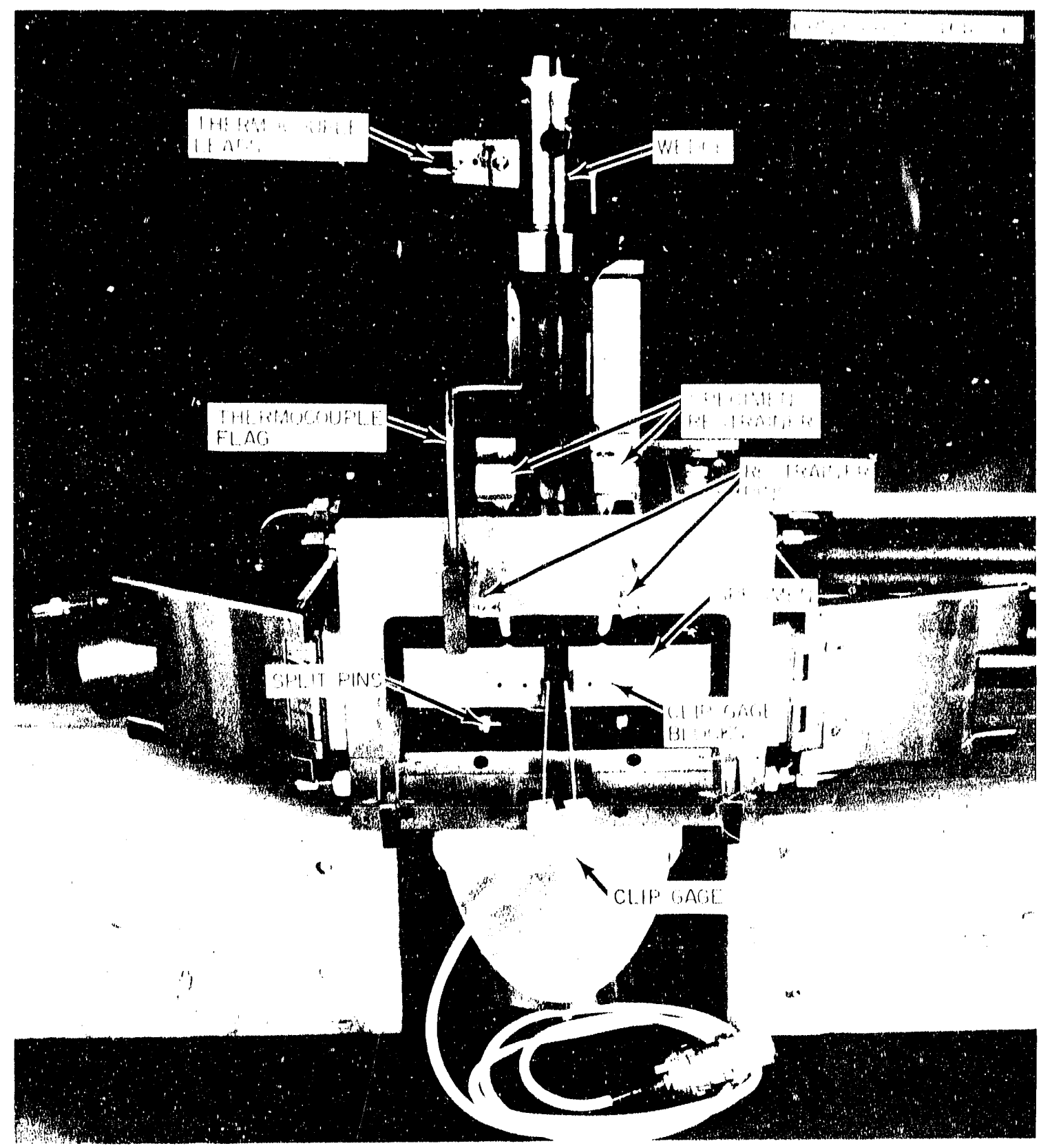

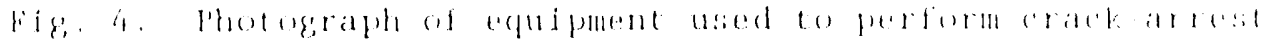

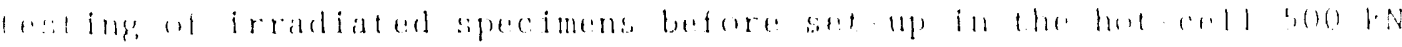
1,.el ing, mitr hion. 
Figure 5 shows a closeup view of the environmental chamber used for temperature conditioning of the crack-arrest specimens after it was installed in the hot cell $500 \mathrm{kN}$ tensile testing machine. Figure 6 gives a general view of the test system as it is being prepared for a crackarrest test.

Temperature conditioning below ambient is obtained by venting cold nitrogen gas inco the chamber containing the crack-arrest specimen. Above ambient, temperature control is achieved by means of $s$ ix heater elements. Four of these elements are cartridge type and are embedded in the base of the fixture. Two U-shaped heater elements can be moved into place below or above the specimen. After the specimen is positioned in the fixture, a contact thermocouple is lowered onto the specimen surface near the midpoint of the crack path to measure the specimen temperature.

Considerable effort was made to ensure temperature uniformity and accuracy in each crack-arrest specimen. Specimens of A $533 \mathrm{~B}$ steel and of the same three sizes as those to be tested were instrumented with thermocouples and thermally conditioned in the fixture over the relevant temperature range in both normal and inverted configurations. The uniformity and accuracy of the temperature throughout the spectinen were within $\pm 1^{\circ} \mathrm{C}$ when compared to the values measured by the contact thermocouple used during testing.

The clip gage used for the irradiated specimen tests was specially designed and fabricated at ORNL. Long clip-gage arms were incorporated in the design to measure the crack mouth opening displacement (CMOD) from outside the temperature conditioning chamber. The arms are instrumented with temperature-compensated electrical resistance strain gages Moreover, tests outside the hot cell have shown that the clip-gage temperature is $<35^{\circ} \mathrm{C}$ when the specimen temperature ${ }^{*}$ is $350^{\circ} \mathrm{C}$. Since the maximum test temperature for this series of tests is under $150^{\circ} \mathrm{C}$, the clip-gage is calibrated at room temperature with no significant loss in accuracy. The clip-gage was calibrated in the hot cell with a Boekler micrometer before and after every test since the CMOD (not the load) measured during the test is central to the determination of the crackarrest toughness $K_{a}$. The error in $K_{a}$ due to errors in the measurement of CMOD is estimated to be less than 28 .

An irradiat. specimen to be tested is placed in the conditioning chamber, and special "knives" are used to center the specimen beneath the loading wedge. The sides of the loading wedge were covered with a replaceable strip of Teflon ${ }^{\text {TM }}$ to reduce the friction between the wedge and the split pins. The testing machine ram was then raised until the loading wedge fust touches the split pins (a load of about $40 \mathrm{~N}$ ); then the ram is lowered until no-load is indicated. The centering "knives" were then removed since the proper position of the specimen is maintained by the inserted load wedge. The clip-gage is then seated in conical grooves of gage blocks welded (prior to irradiation) to the crack-arrest

"For the purposes of this test, thermocouples were tack-welded to the test specimen. 


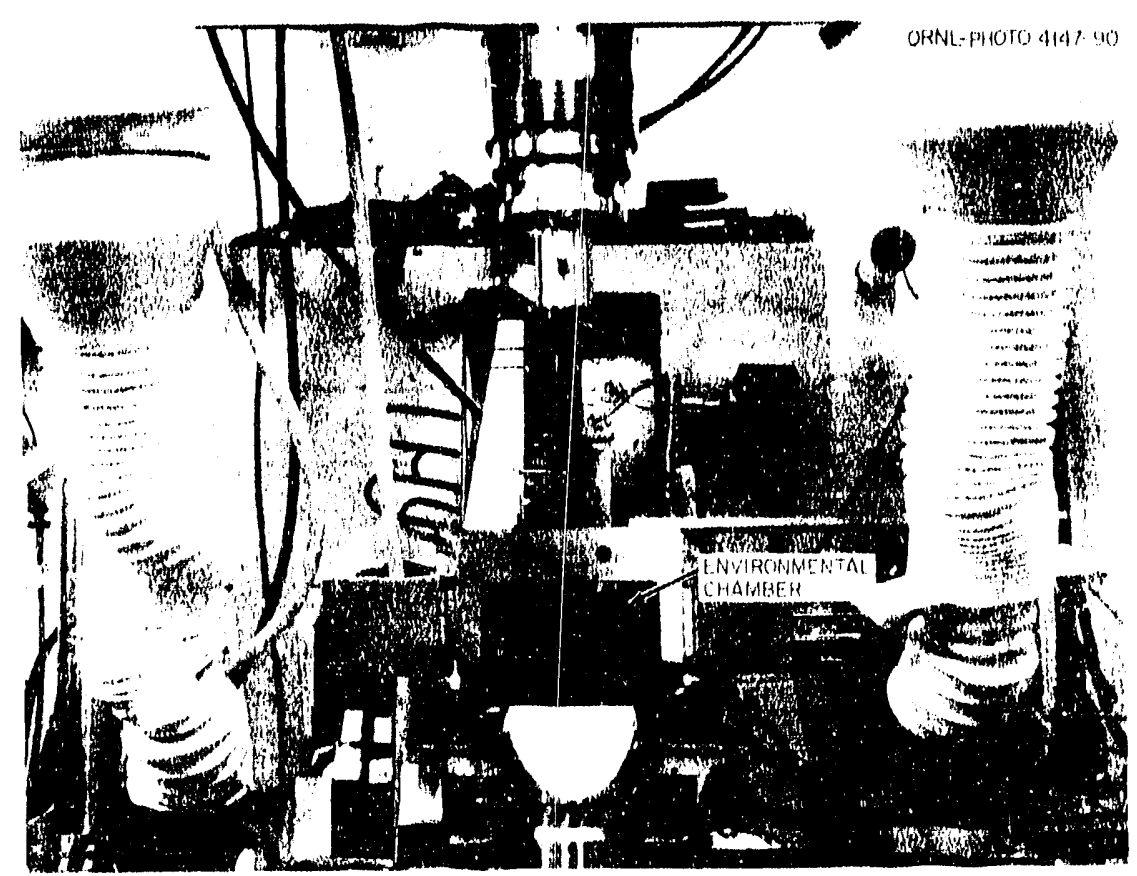

Fig, 5. cioseup view of the envirommental chamber used for temperature conditioning of the crack-arrest spectmens after installation in the hot-ce11 $500-\mathrm{kN}$ tronslje testing machlue.

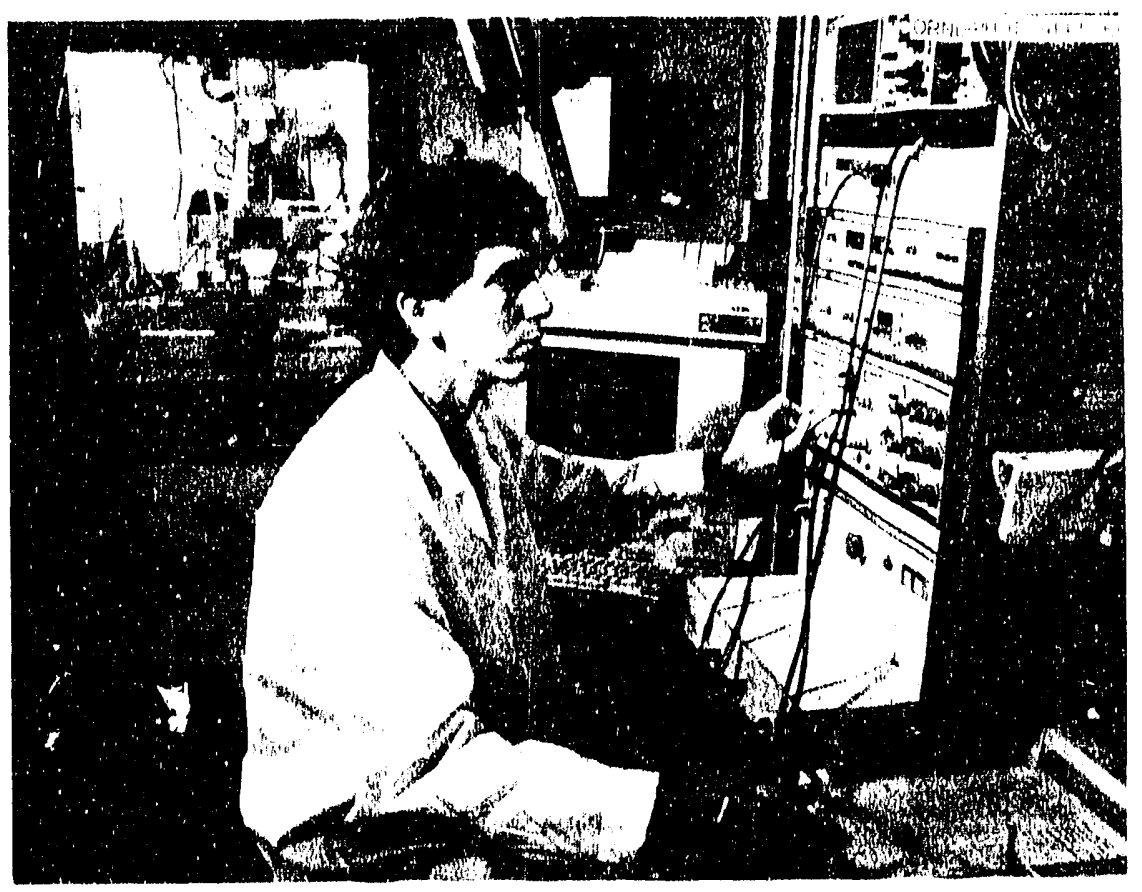

Fig. 6. Goneral view of the test system as it is being prepared for a crack-arrest test. 
specimen. The load vs CMOD is recorded on an X-Y plotter together with the clip-ligage calibration marks; a typical chart from a test is shown in Fig. 7. The clarts from all the irradiated tests are included in Appendix $E$. As mentioned above, the value of the load is not used in the calculattion of $K_{a}$. However, the plot of load vs CMOD is indispensable in the conduct of the test and determination of the CMOD at various points in the loading-unloading cycles (see ASTM E 1221-88).

\subsection{An/alys is Procedures}

The arrested crack front is marked by lisat-tinting the specimen after testing. The specimen is then cooled with liquid nitrogen and broker open. The length of the remaining ligament for each specimen is obtalined by measuring the position of the arrested crack front by using the averaging procedure prescribed in ASTM E 1221-88. In the case of irracliated specimens, a digitlzing tablet was used to measure the length of the remafning ligament on a photograph taken through a Kollmorgan periscope of the broken specimen half. Typical fracture surfaces for two 33- $\times 152-\mathrm{mm}$ specimens are shown in Fig. 8 (photographs of the fracture suritaces of all the specimens tested are given in Appendix E). Numerous unbroken ligaments, typical for pressure vessel steels at these test temperatures, can be observed on the fracture surface of the specimens. The known dimensions of the specimen serve as the scale for these measurements. In the case of the unirradiated specimens, the length of the remaining ligament is directly measuren by a digital. measuring inicroscope. The errors due to the measurement method are estimated to be less than those due to the shape of the crack front.

To estimate accuracy of the crack-arrest toughness, two values of the stress intensity factor $\left(K_{o}\right.$ and $K_{a}$ ) are calculated. The former is the stress intensity factor at crack initiation, and the latter is the value sholt ty after arrest. Both values are calculated by substituting appropriate values in the following expressions given in ASTM E 1221-88:

$$
\left.K=E \delta f(x) \sqrt{\left[B /\left(B_{N} W\right)\right.}\right] \text {, }
$$

where $f(x)=$ crack-arrest specimen calibration function defined as follows:

$$
f(x)=\frac{2.24\left(1.72-0.9 x+x^{2}\right) \sqrt{(1-x)}}{\left(9.85-0.17 x+11 x^{2}\right)},
$$

and

$$
\begin{aligned}
& x=a / W, \\
& E=y^{\prime} \text { oung's modulus, } \\
& a=\text { initial slot length } a_{0} \text { or arrested (final) crack length } a_{a}, \\
& W=\text { specimen width, } \\
& B=\text { specimen thickness, }
\end{aligned}
$$


ORNL-DWG 90-15134

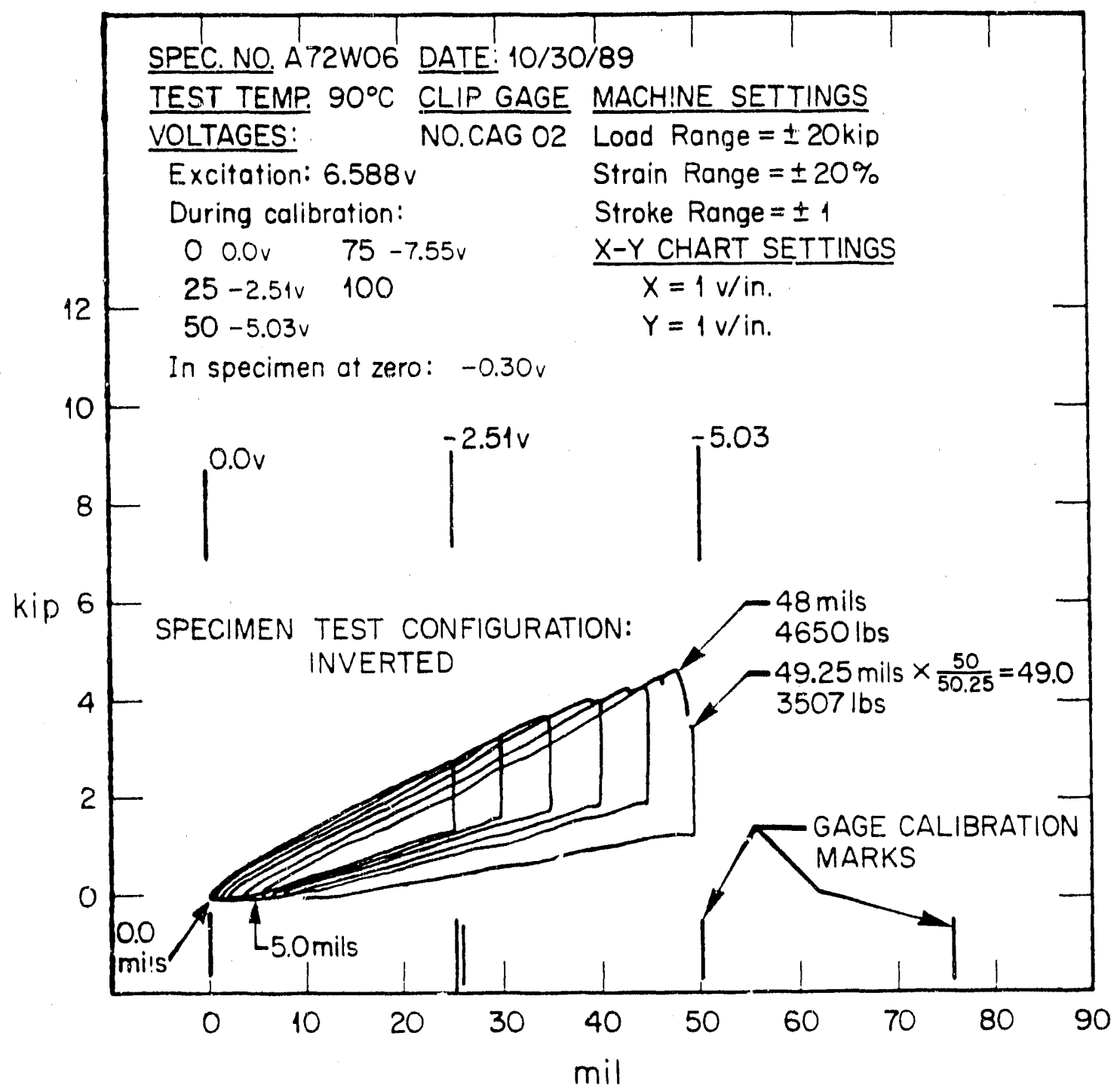

Fig. 7. Chart produced on an $X-Y$ plotter during a typical crackarrest test of an irradiated specimen. 


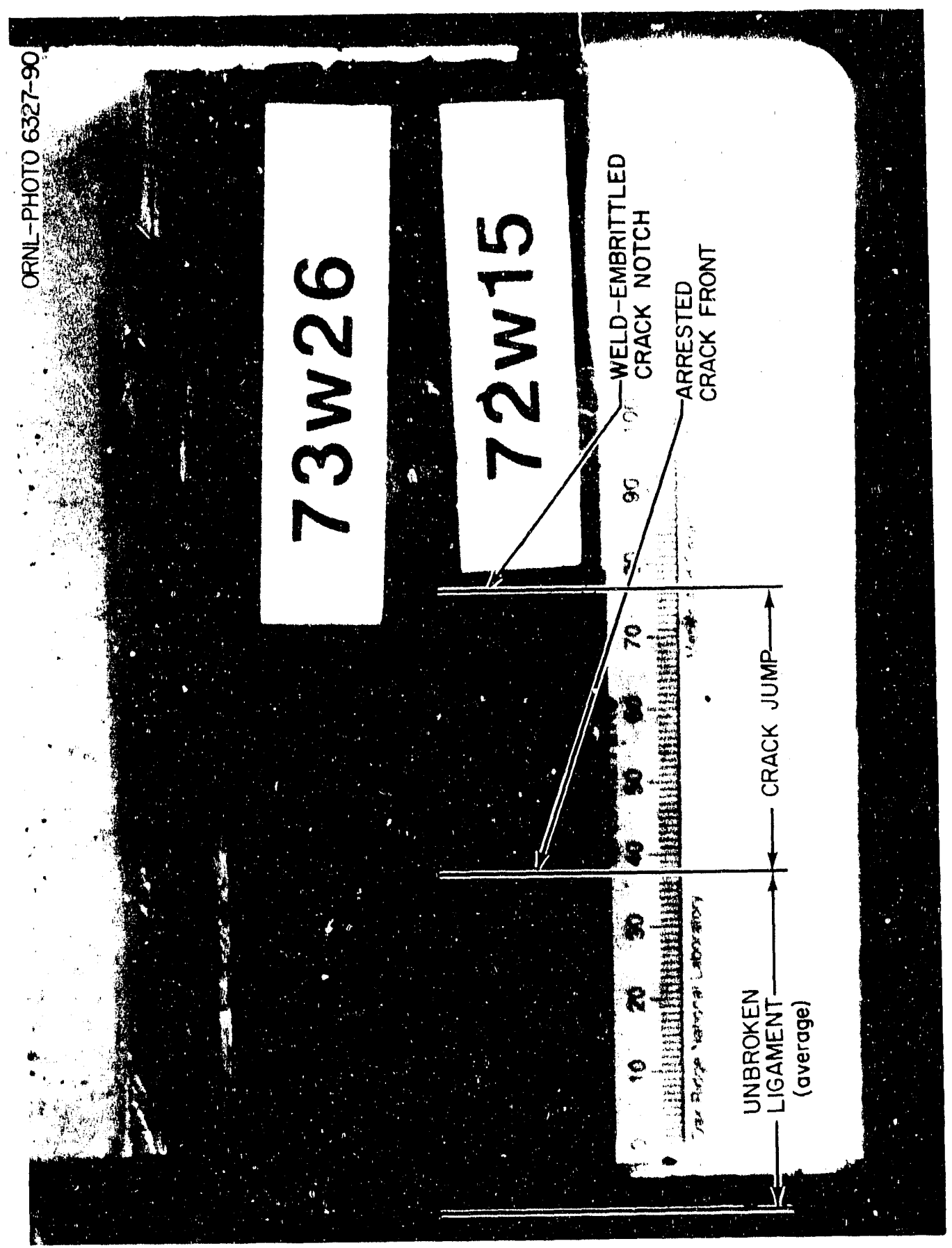
要

4

E

出

(1)

$\Phi$

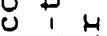

को

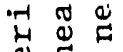

品

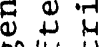

क्षै

क

舟。

卷

U

द疑苛

品

司范。

본

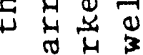

F

ปै

艺啠完

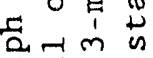

荧

D.

只先

至。

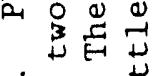

$\infty$ 㟧. 兽

of o 5

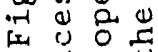

$\pi$

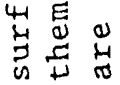


$\mathrm{B}_{\mathrm{N}}=$ specimen thickness at crack plane,

$\delta=$ CMOD.

If all other values are unchanged the error in $\mathrm{K}$ is directly proportional to the error in $\delta$ (given above). The error in $K$ due to errors in crack length is estimated as described below.

In Eq. (1), if all other values are constant, the error in $\mathrm{K}$ is equal to that of $f(x)$ due to the error in the fractional crack length $x$. Table 4 shows various estimates of the errors in $f(x)$ resulting from the measurement of the initial slot length $a_{0}$ and arrested crack length $a_{a}$ and for the various specimen sizes. A plot of $f(x)$ vs fractional crack length $x$, shown in Fig. 9, is nearly linear in $x$. However, because $f(x)$ decreases as $x$ increases, the absolute value of the average relative error in $f(x)$ increases as $x$ increases. The average relative error is defined as:

$$
1 / 2 \frac{f[(1+e) x]-f[(1-e) x]}{f(x)}
$$

Two relevant values of $x$ are 0.33 for the initial slot length and 0.85 for the final crack length. The former is the minimum value for the crack-arrest specimens manufactured for the Sixth Series program, and the latter is the maximum valid value allowed by ASTM E 1221-88. A \pm 18 change for $x=0.33$ results in a 70.58 change in $f(x)$, while the same +18 change for $x=0.85$ results in an approximately $\mp 38$ change in $f(x)$.

The determination of $a_{0}$ is performed with a digital measuring microscope, and the error is estimated to be $<0.2 \mathrm{~mm}$, irrespective of the specimen size. Hence the maximum error in $f(x)$ (and $k_{0}$ ) for the initial slot length is \pm 0.58 for a small specimen and even less for a large specimen. In both cases, the initial slot length is used to estimate $K_{o}$, which gives an estimate of $K$ at the onset of rapid fracture. It is an estimate at best because the crack at initiation is not a sharp one and has a finite root radius. Moreover, $\mathrm{K}_{0}$ is of interest to the experimenter only.

As mentioned, the measurement of the final crack length $a_{a}$ is performed according to ASTM E $1221-88$ by an averaging procedure. Since it is rare that the arrested crack front is square or straight (Fig. 8), it is difficult to estimate the error in such a determination. From the expression for $\mathrm{K}_{\mathrm{a}}$ given in ASTM E 1221-88, estimates of the error were made by using different values of the arrested crack length to obtain bounds on the error. A maximum value of $a_{a}$ is $54 \mathrm{~mm}$ for a small $25 \times 76$ $\times 76 \mathrm{~mm}$ specimen since this is the maximum length permitted in E 1221-88 for this specimen size. Errors of \pm 1 or $\pm 2 \mathrm{~mm}$ in $a_{a}$ for this case result in errors of 76.58 or $\mp 138$, respectively, in $K_{a}$. A similar procedure was followed for the large $(33 \times 152 \times 152 \mathrm{~mm})$ specimen. The error estimates are summarized in Table 4. The total maximum error in $\mathrm{K}_{\mathrm{a}}$ from all sources is estimated to be approximately \pm 10 o for the small specimens and $\pm 5 \%$ for the large ones. 


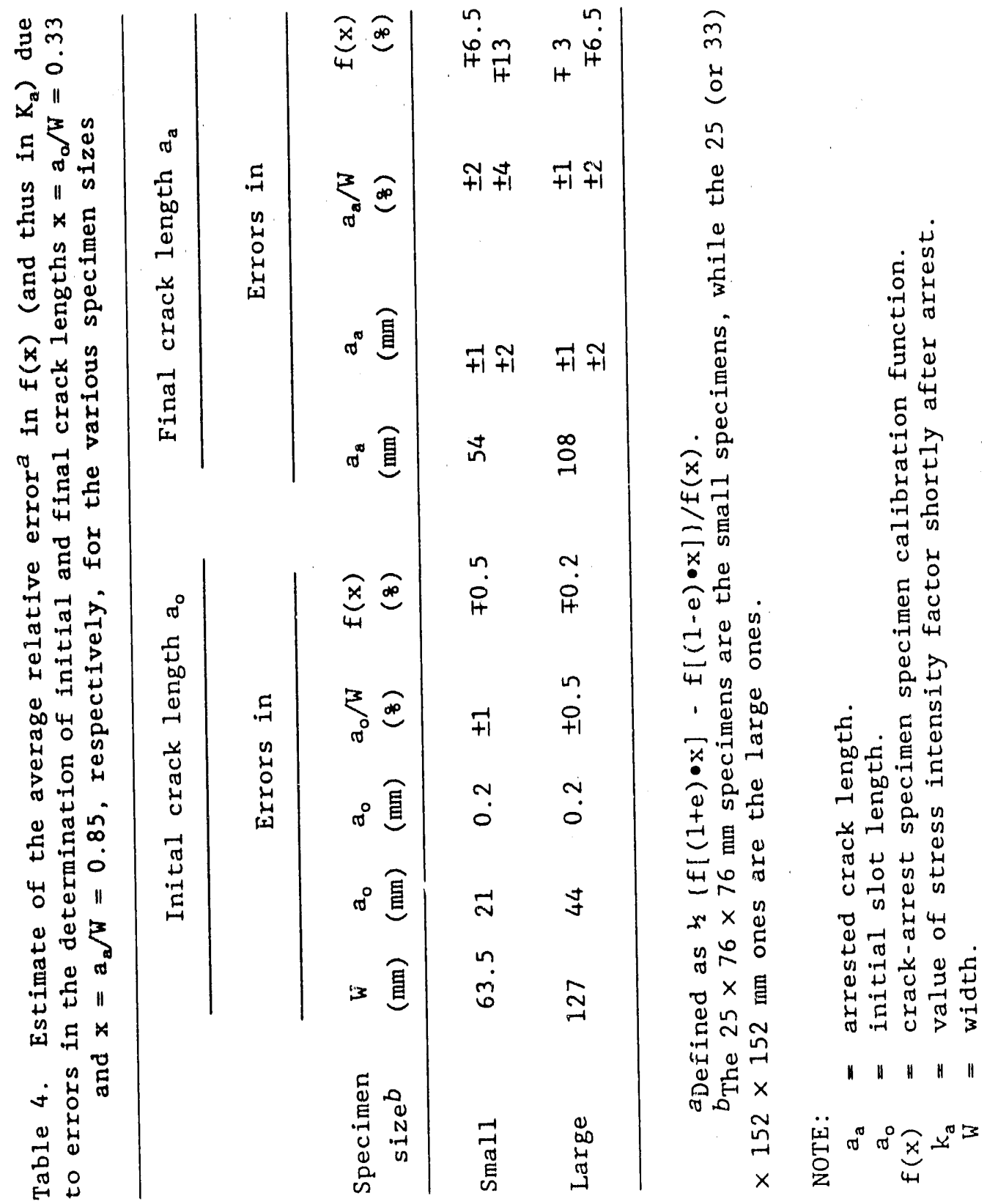




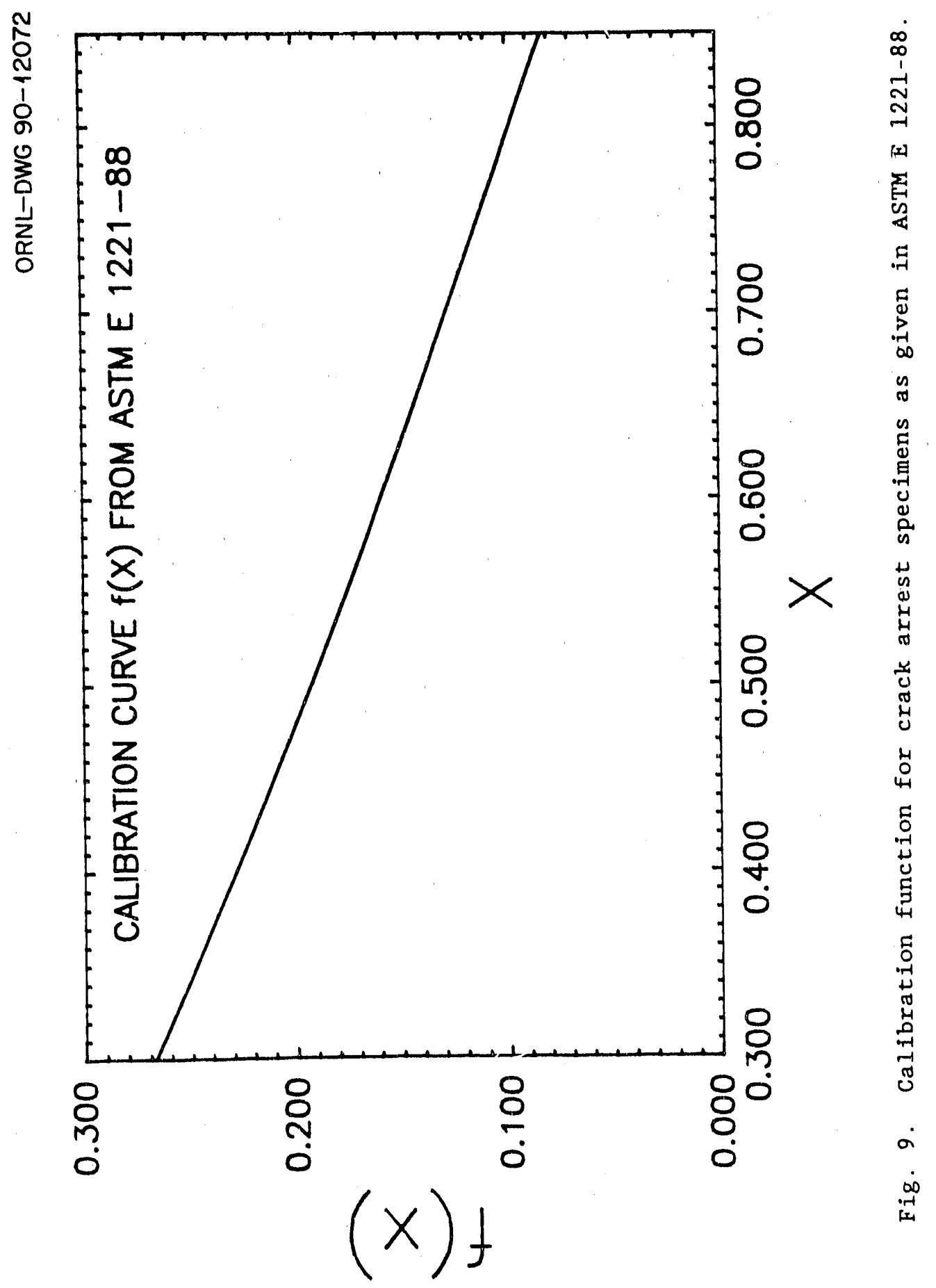




\section{RESULTS AND DISCUSSION}

The temperature control for the two irradiation capsules, each containing 30 specimens, was excellent. The temperature most of both weld-embrittled and duplex-type specimens (22 in one capsule and 23 in the other) ranged from 286 to $290^{\circ} \mathrm{C}$, while the few remaining specimens were irradiated at temperatures ranging from 280 to $286^{\circ} \mathrm{C}$. The average irradiation temperature of the weld-embrittled-type crack-arrest specimens is 286 and $285^{\circ} \mathrm{C}$ for the $72 \mathrm{~W}$ and $73 \mathrm{~W}$ specimens, respectively. For both $72 \mathrm{~W}$ and $73 \mathrm{~W}$ specimens, the fluences to which the weldembrittled-type crack-arrest specimens were irradiated ranged from approximately 1.4 to $2.4 \times 10^{19}$ neutrons $/ \mathrm{cm}^{2}(>1 \mathrm{MeV})$, and the average fluence and standard deviation is aporoximately 1.9 and $0.3 \times 10^{18}$ neutrons $/ \mathrm{cm}^{2}(>1 \mathrm{MeV})$, respectively. Bar charts showing the distribution of fluence of the specimens successfully tested, 18 and 17 from the $72 \mathrm{~W}$ and $73 \mathrm{~W}$ weldments, respectively, are given in Figs. 10 and 11 , respectively. The average irradiation temperature and the exposure values of each specimen are given later in this report. A summary of the irradiation data for the weld-embrittled specimens tested in Phase 1 is given in Table 5. Detailed reports on the dosimetry and operating history of the two capsules will be published separately.

The yield strength and Young's modulus of the test material are required in crack-arrest testing. Young's modulus is calculated from the following expression, from Ref. [5]: $E=207.2-0.0571 \mathrm{~T}$, where $E$ - Young's modulus in $\mathrm{GPa}$, and $\mathrm{T}$ - temperature in ${ }^{\circ} \mathrm{C}$ (discussed also in Appendix $C$ ). The unirradiated and irradiated tensile strengths have been reproduced from Ref. [3] in Figs. 12 and 13 for welds $72 \mathrm{~W}$ and $73 \mathrm{~W}$, respectively. The average fluence of the tensile samples, approximately $1.6 \times 10^{9}$ neutrons $/ \mathrm{cm}^{2}(>1 \mathrm{MeV})$, is about 158 less than that for the crack-arrest specimens. This difference will not affect the values of the crack-arrest toughnesses $K_{a}$ but could have a small effect on the validity of each specimen as it is prescribed in ASTM E 1221-88. The observations in this report are preliminary.

The $\mathrm{RT}_{\mathrm{NDT}}$ values for both weldments in the unirradiated and irradiated conditions are given in Table 6 (from Refs. [3] and [4]). The initial $\mathrm{RT}_{\mathrm{NDT}}$ values were determined in accordance with Subarticle NB-2330 of ASME Boiler and Pressure Vessel Code, Sect. III, and are the same as the drop-weight NDT values. The "adjusted" $\mathrm{RT}_{\mathrm{NDT}}$ values were determined according to paragraph 10.2 .2 of ASTM E 185-82 by adding the CVN $\triangle T_{41-J}$ values to the initial $\mathrm{RT}_{\mathrm{NDT}}$ values. The $\mathrm{CVN} \Delta \mathrm{TT}_{42-\mathrm{J}}$ shifts have been determined from a relatively large number of specimens, as shown in Fig. 14 (also from Refs. [3] and [4]). Approximately 84 and 56 unirradiated and irradiated CVN specimens were tested from each of the $72 \mathrm{~W}$ and $73 \mathrm{~W}$ welds respectively. The average fluence of CVN-impact energy specimens for both the $72 \mathrm{~W}$ and $73 \mathrm{~W}$ weldments is $1.51 \times 10^{19}$ neutrons $/ \mathrm{cm}^{2}$, 


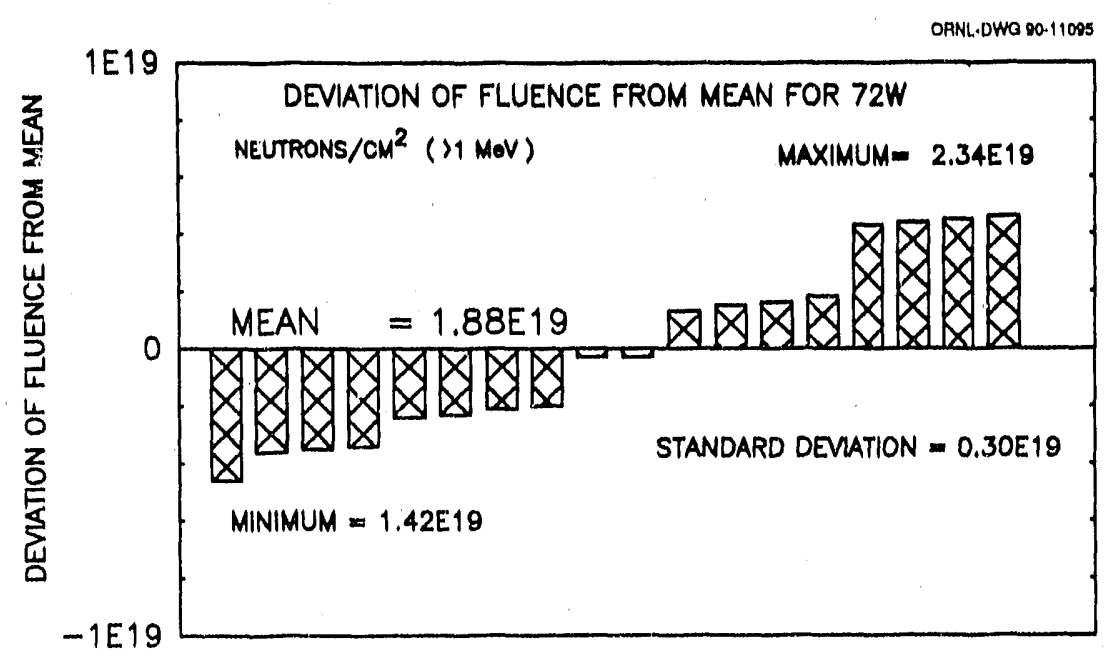

Fig. 10. Distribution of fluence in the 18 irradiated weld-embrittled-type crack specimens tested from the $72 \mathrm{~W}$ weld.

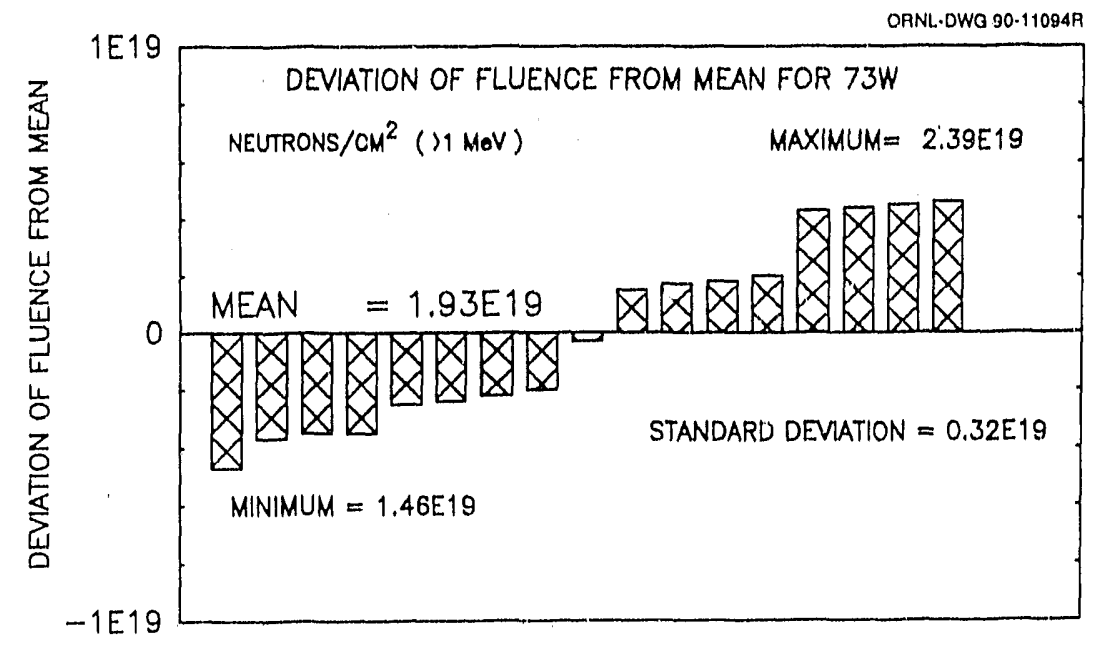

Fig. 11. Distribution of fluence in the 17 irradiated crack specimens of the $73 \mathrm{~W}$ weld that were tested successfully.

Table 5. Summary of the irradiation temperature and fluence for Series $72 \mathrm{~W}$ and $73 \mathrm{~W}$ crack-arrest specimens

\begin{tabular}{|c|c|c|c|c|}
\hline & \multicolumn{2}{|c|}{$72 \mathrm{~W}$ (18 specimens) } & \multicolumn{2}{|c|}{$73 \mathrm{~W}$ (17 specimens) } \\
\hline & $\begin{array}{l}\text { Temperature } \\
\left({ }^{\circ} \mathrm{C}\right)\end{array}$ & Fluence ${ }^{a}$ & $\begin{array}{c}\text { Temperature } \\
\left({ }^{\circ} \mathrm{C}\right)\end{array}$ & Fluence ${ }^{a}$ \\
\hline Mean & 286 & 1.88 & 285 & 1.93 \\
\hline Standard Deviation & 3 & 0.30 & 3 & 0.32 \\
\hline Minimum & 281 & 1.42 & 280 & 1.46 \\
\hline Maximum & 289 & 2.34 & 289 & 2.39 \\
\hline
\end{tabular}

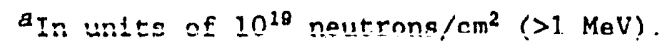


ORNL-DWG 90-15463

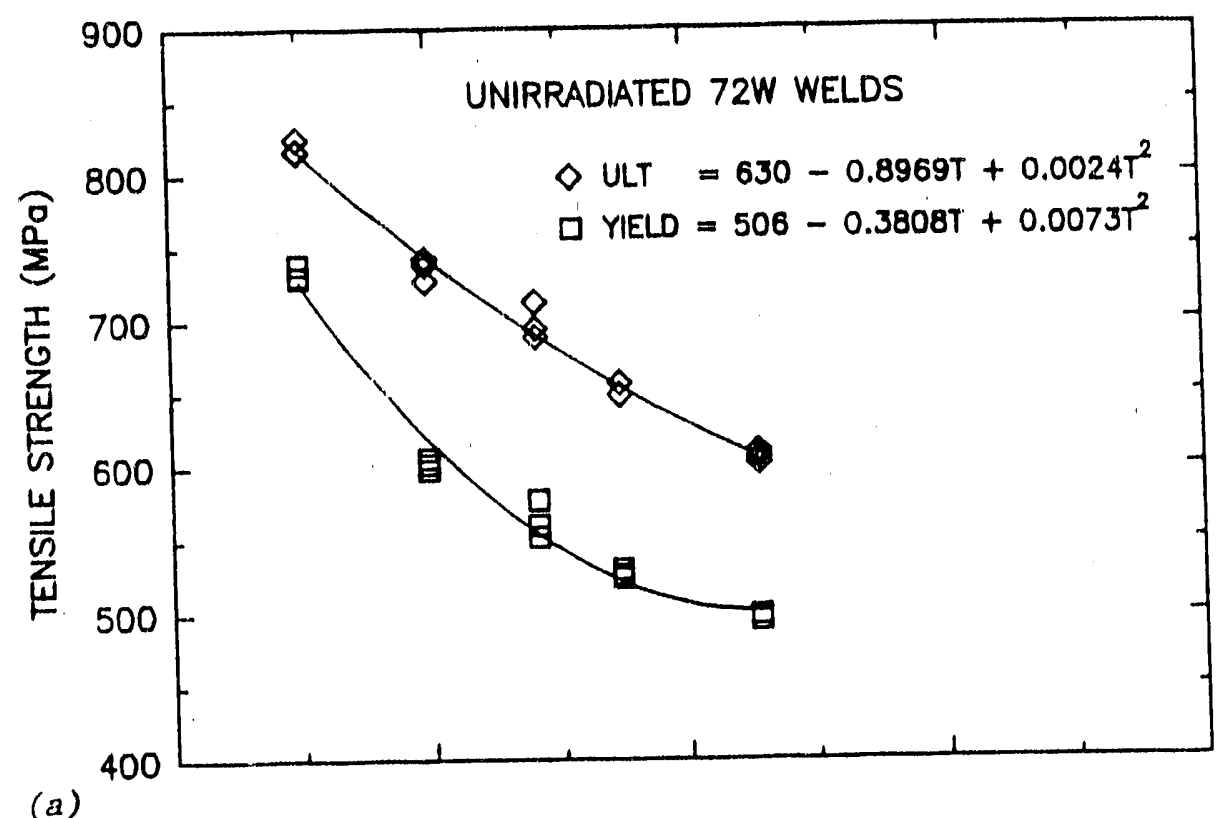

(a)

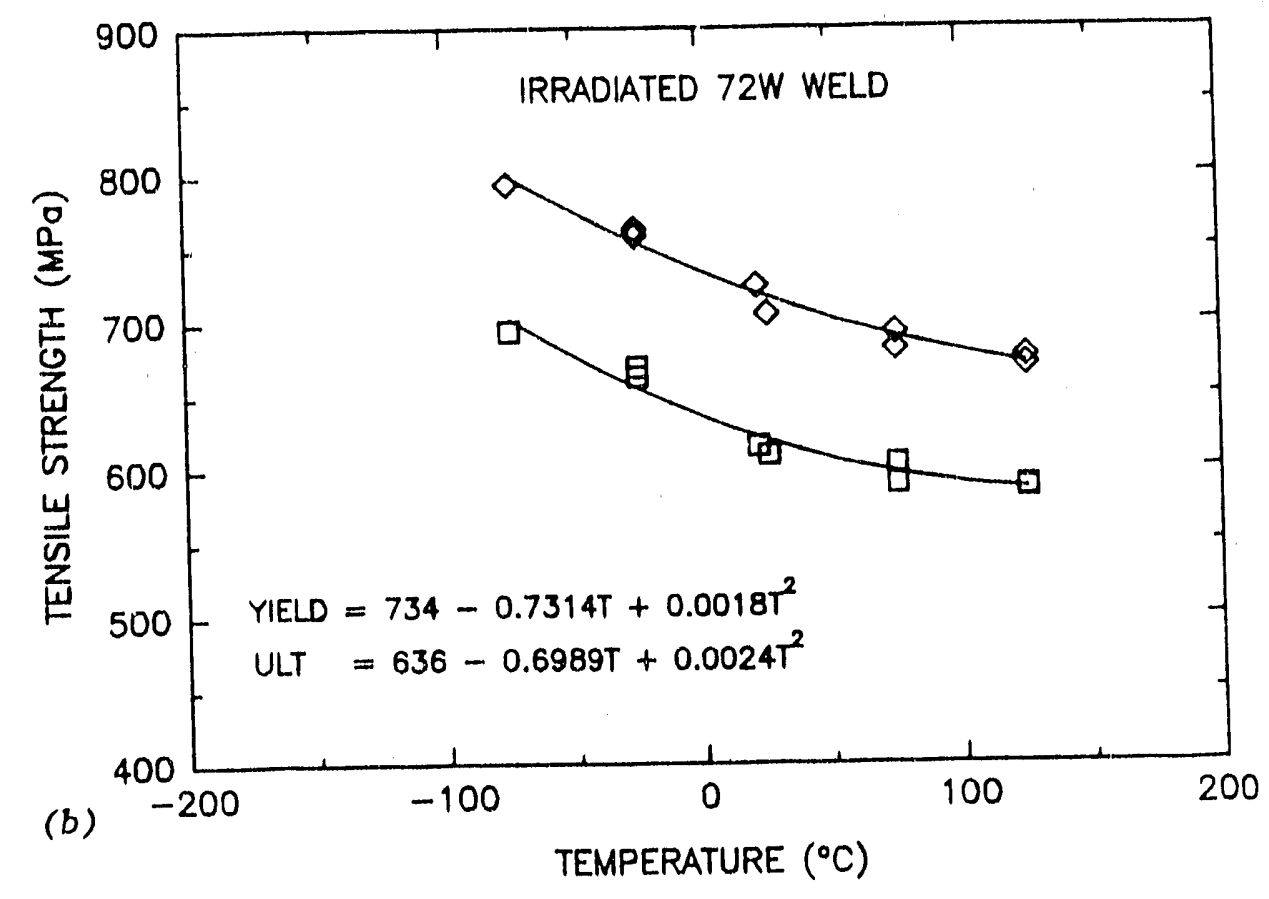

Fig. 12. Yield and ultimate strengths vs test temperature for weld $72 \mathrm{~W}$ (a) unirradiated and (b) irradiated at a nominal temperature of $288^{\circ} \mathrm{C}$ to $1.57 \times 10^{18}$ neutrons $/ \mathrm{cm}^{2}(>1 \mathrm{MeV})$. 

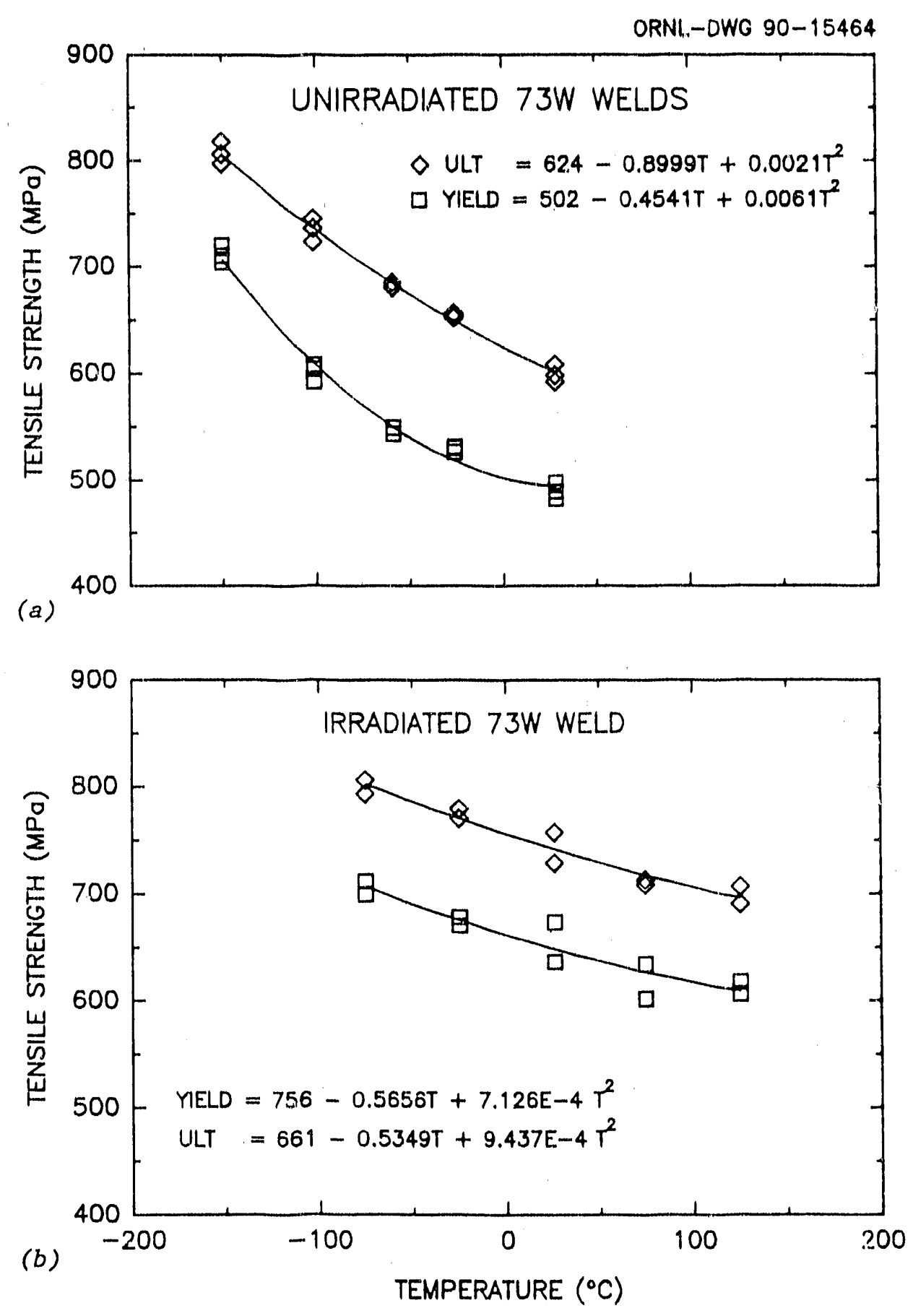

Fig. 13. Yield and ultimate strengths vs test temperature for weld $73 \mathrm{~W}$ (a) unirradiated and (b) irradiated at a nominal temperature of $288^{\circ} \mathrm{C}$ to $1.56 \times 10^{19}$ neutrons $/ \mathrm{cm}^{2}(>1 \mathrm{MeV})$. 


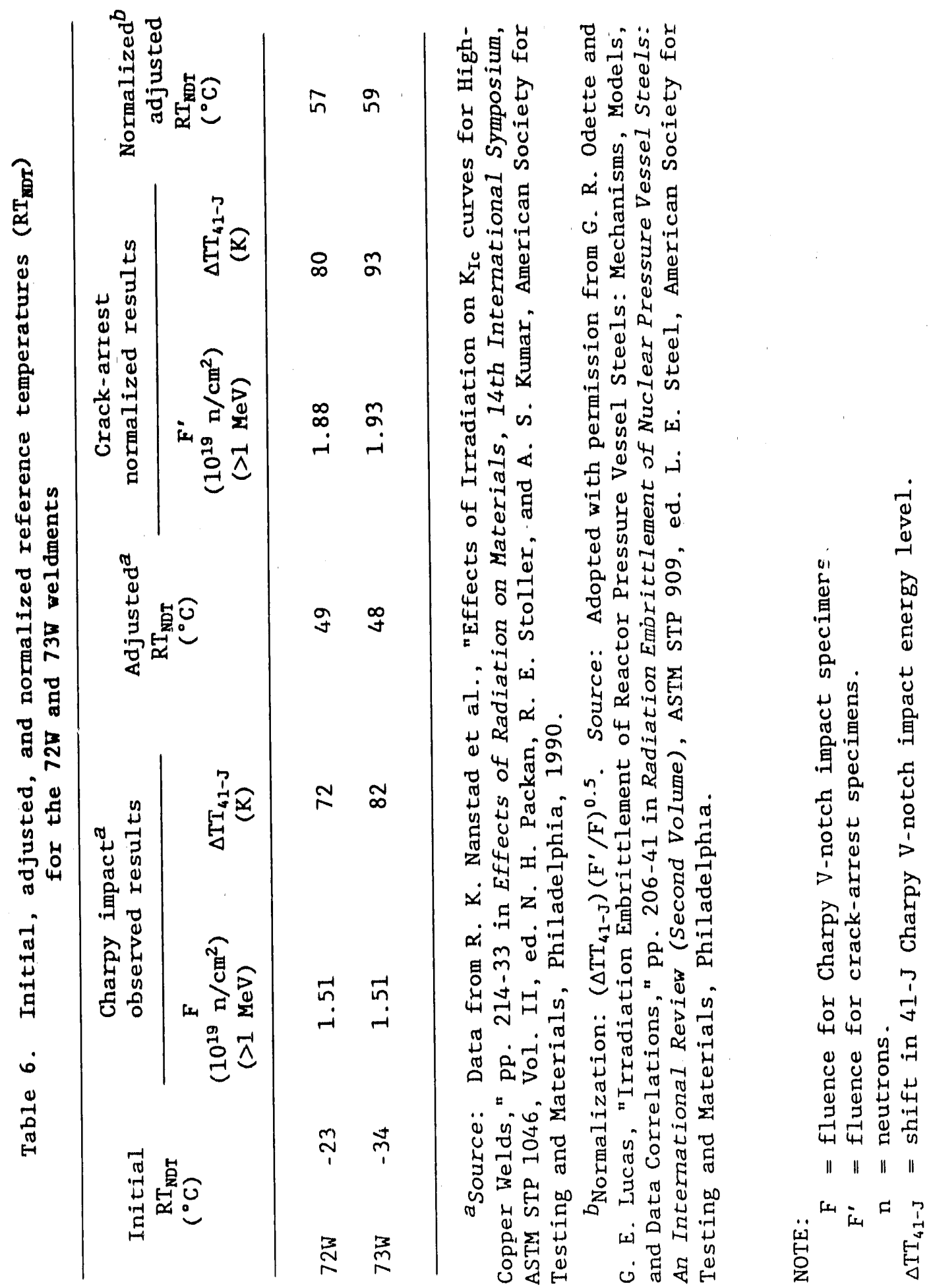


OKNI.*DWG $89 C \cdot \cdot 19510$

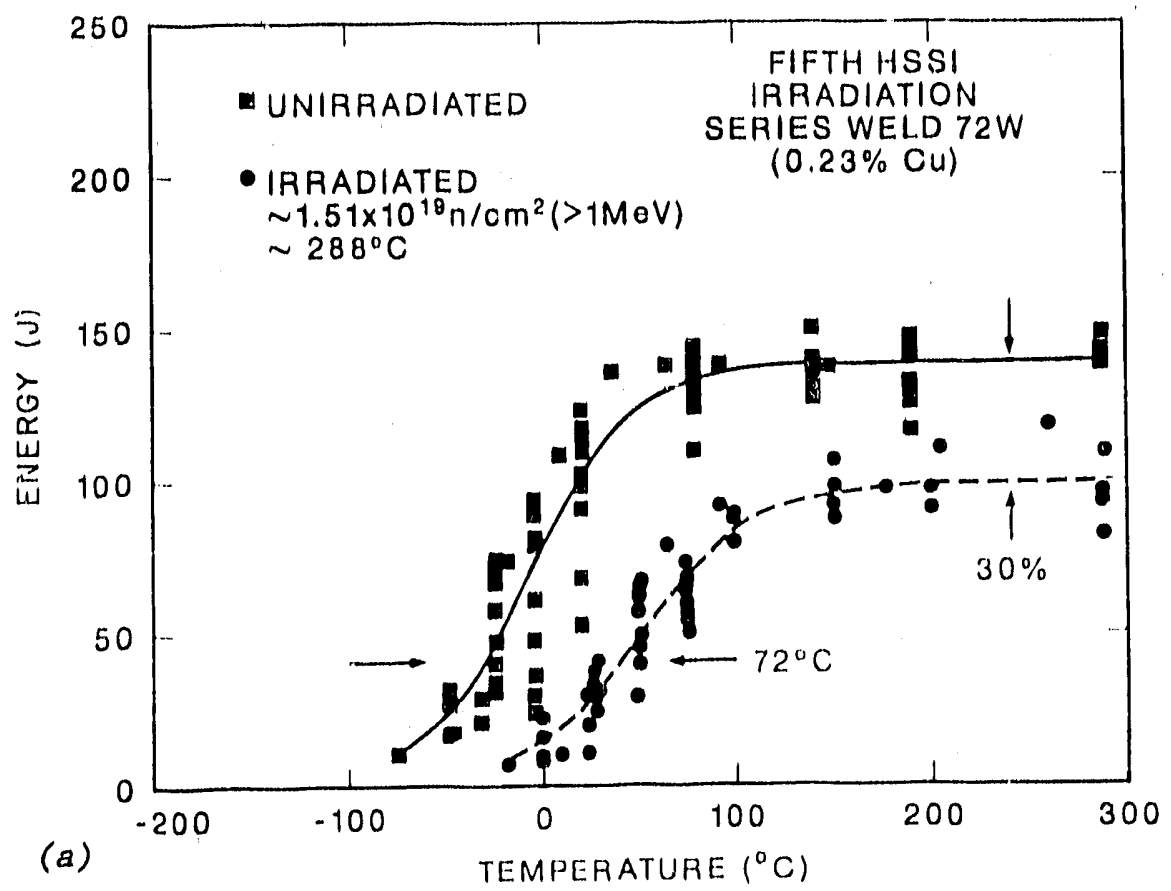

ORN11-13WO $800-196014$

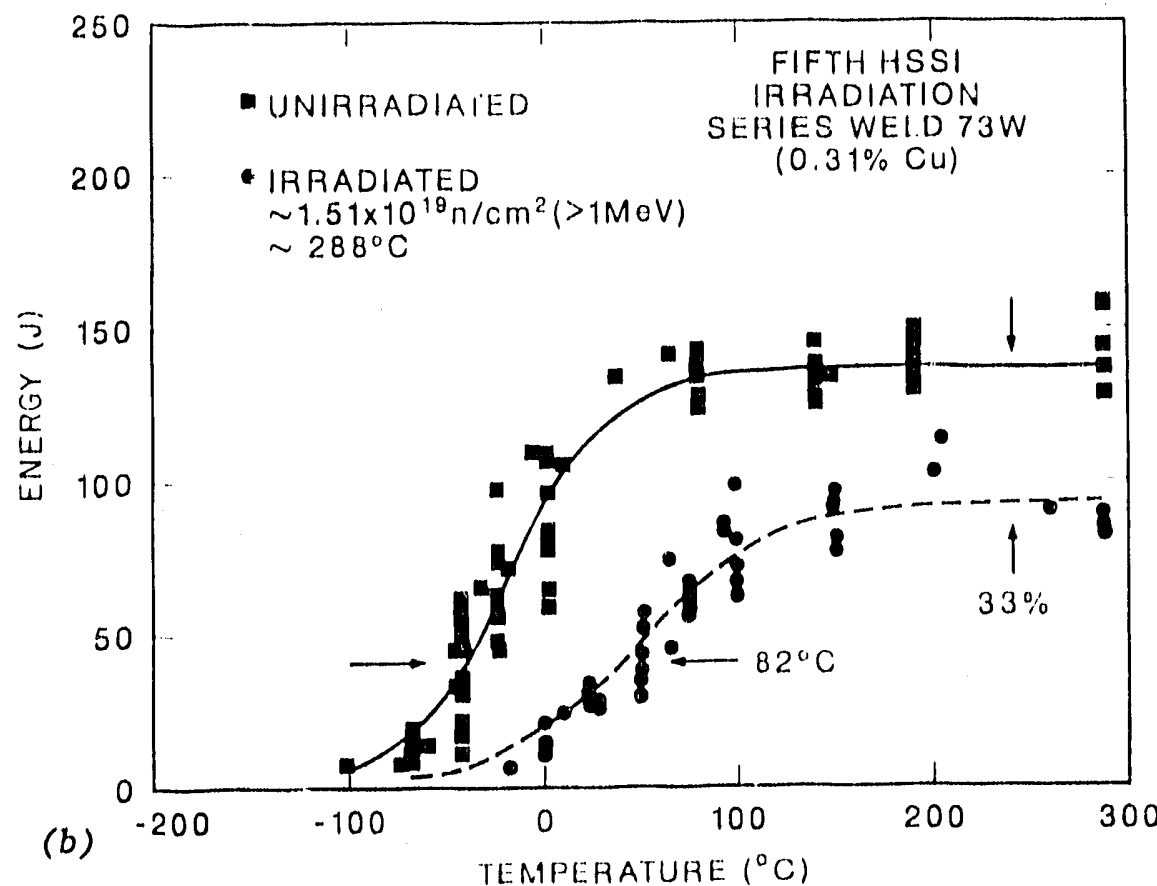

Fig. 14. Charpy V-notch-impact energy vs test temperature for welds $72 \mathrm{~W}$ and $73 \mathrm{~W}$ (a) unirradiated (b) irradiated at a nominal temperature of $288^{\circ} \mathrm{C}$ to $1.51 \times 10^{19}$ neutrons $/ \mathrm{cm}^{2}(>1 \mathrm{MeV})$. 
while that for the crack-arrest specimens is approximately $1.9 \times 10^{18}$ neutrons $/ \mathrm{cm}^{2}$. To normalize the $\mathrm{RT}_{\mathrm{NDT}}$ shift, an average trend curve applicable to the behavior of test reactor data and having a slope of 0.5 was used (Ref. [6]). It is of the form:

$$
\text { Normalized } \Delta \mathrm{TT}_{41-\mathrm{J}}=\left(\Delta \mathrm{TT}_{41-\mathrm{J}}\right)\left(\phi^{\prime} / \phi\right)^{0.5},
$$

where $\phi^{\prime}$ and $\phi$ are the average fluences for the crack-arrest and the CVINimpact specimens, respectively, in neutrons per square centimeter $(>1 \mathrm{MeV})$. Both shifts for each weldment are given in Table 6 . The normalized $\mathrm{RT}_{\mathrm{NDT}}$ values were used to shift the ASME $\mathrm{K}_{I_{a}}$ curves shown later in this report.

Tables 7 and 8 give the results of testing the unirradiated crackarrest specimens of the $72 \mathrm{~W}$ and $73 \mathrm{~W}$ Series, respectively, and Tables 9 and 10 give data for the irradiated specimens of these two series. These tables also give for each specimen the irradiation temperature and the exposure value [fluence for energies $>1 \mathrm{MeV}$ and $>0.1 \mathrm{MeV}$ as well as displacements per atom (dpa)]. The $K_{a}$ values have not been normalized to a single average fluence to account for the variation of fluence from one specimen to another.

In testing of one specimen, A73W17 (11sted in Table 10), the crack falled to initiate in a cleavage mode and exhibited tearing. It was retested at $30^{\circ} \mathrm{C}$, but the crack did not arrest, and the specimen broke. The $K_{a}$ value from specimen $A 73 W 37$ (tested at $-25^{\circ} \mathrm{C}$ ) is recognized as too low because the arrested crack length $a_{a}$ is 968 of the nominal specimen width $W$. The expression in ASTM E 1221-88 used to calculate $K_{a}$ is 1 imited to $a_{a} / W \leq 0.85$. While other specimens may be slightly invalid and hence may or may not necessarily represent plane-strain behavior, the authors belleve this specimen to be so far beyond the validity limits as to be clearly nonrepresentative of plane-strain crack-arrest toughness of the weld. Hence, its position below the ASME $K_{I a}$ curve is of no significance. In general, even though some of the other individual specimens may not strictly meet all of the ASTM validity criteria, the authors believe the data to be representative of the arrest toughness that would exist within a thick-walled RPV.

The task group responsible for crack-arrest test procedure ASTM E 1221-88 recognized the need for the data to represent plain-strain conditions. Conservative validity criteria were selected on the basis of existing analytical and experimental results (Ref. [7]) to ensure that specimens meeting those criterla would indeed be representative of planestrain conditions. Even at the time ASTM E 1221-88 was written, however, it was recognized that those criteria might be overly restrictive; they were, nonetheless, chosen to be used until more evidence justifying their relaxation could be amassed. More data are now avallable; for example, Ref. [8] shows crack-arrest test results clearly violating the size criteria of ASTM E 1221-88, that still accurately predict the arrest behavior of a thick-walled pressure vessel under simulated pressurizedthermal-shock loading. On the bases of these and other considerations, the ASTM task group will be asked to reconsider relaxation of the validity criteria. 
Table 7. Unirradiated crack-arrest toughness data obtained from testing weldment $72 \mathrm{~W}$ $\left(R T_{\text {NDT }}=-23^{\circ} \mathrm{C}\right)$

\begin{tabular}{|c|c|c|c|}
\hline Specimen & $\begin{array}{c}\text { Test } \\
\text { temperature } \\
\left({ }^{\circ} \mathrm{C}\right)\end{array}$ & $\begin{array}{c}\mathrm{K}_{\mathrm{a}} \\
(\mathrm{MPa} \cdot \sqrt{\mathrm{m}})\end{array}$ & Validitya \\
\hline
\end{tabular}

Weld-embrittled $25 \times 76 \times 76 \mathrm{~mm}$ specimens

$\begin{array}{llrl}\text { A72W37 } & -61 & 66 & \\ \text { A72W35 } & -60 & 53 & \\ \text { A72W38 } & -59 & 57 & \\ \text { A72W36 } & -47 & 71 & \\ \text { A72W34 } & -45 & 73 & \\ \text { A72W24 } & -30 & 61 & \\ \text { A72W28 } & -30 & 60 & \text { B } \\ \text { A72W25 } & -30 & 79 & \text { B, E } \\ \text { A72W31 } & -15 & 108 & \end{array}$

Weld-embrittled $25 \times 152 \times 152 \mathrm{~mm}$ specimens

$\begin{array}{lrrr}\text { A72W44 } & -60 & 76 & \\ \text { A72W39 } & -60 & 45 & \text { A } \\ \text { A72W20 } & -47 & 67 & \\ \text { A72W41 } & -45 & 74 & \\ \text { A72W46 } & -45 & 92 & \\ \text { A72W43 } & -32 & 92 & \\ \text { A72W08 } & -30 & 104 & \\ \text { A72W05 } & -30 & 107 & \\ \text { A72W48 } & -30 & 98 & \\ \text { A72W01 } & -16 & 97 & \text { C } \\ \text { A72W03 } & -14 & 128 & \end{array}$

Weld-embrittled $33 \times 152 \times 152 \mathrm{~mm}$ specimens

$\begin{array}{lrrr}\text { A72W45 } & -45 & 76 & \\ \text { A72W47 } & -30 & 91 & \\ \text { A72W07 } & -15 & 103 & \\ \text { A72W04 } & -15 & 94 & \\ \text { A72W19 } & -15 & 94 & \\ \text { A72W02 } & 0 & 93 & \\ \text { A72W12 } & 0 & 114 & \\ \text { A72W40 } & 0 & 114 & \text { B }\end{array}$


Table 7. (continued)

\begin{tabular}{|c|c|c|c|}
\hline Specimen & $\begin{array}{l}\text { Test } \\
\text { temperature } \\
\left({ }^{\circ} \mathrm{C}\right)\end{array}$ & $\begin{array}{c}\mathrm{K}_{\mathrm{a}} \\
(\mathrm{MPa} \cdot \sqrt{\mathrm{m}})\end{array}$ & Validitya \\
\hline
\end{tabular}

Duplex $33 \times 152 \times 152 \mathrm{~mm}$ specimens

$\begin{array}{lrrr}\text { A72W71 } & -14 & 91 & \\ \text { A72W66 } & -2 & 103 & \\ \text { A72W63 } & -1 & 125 & \\ \text { A72W64 } & 1 & 108 & \\ \text { A72W65 } & 4 & 125 & \\ \text { A72W68 } & 5 & 115 & \\ \text { A72W73 } & 5 & 142 & \text { C, D } \\ \text { A72W62 } & 10 & 136 & \text { B, C } \\ \text { A72W57 } & 21 & 146 & \text { C, D }\end{array}$

Weld-embrittled $51 \times 203 \times 203 \mathrm{~mm}$ specimens

$\begin{array}{rrr}\text { A72W83 } & -30 & 85 \\ \text { A72W85 } & -15 & 95 \\ \text { A72W84 } & 0 & 107\end{array}$

${ }^{a}$ One or more letters for a specimen indicate that the results did not meet one of the ininimum lengths of the ASTM E 1221-88 validity criteria. The letters correspond to those in Table 2 of ASTM E 1221-88, which can be paraphrased as:
$A, B=$ unbroken ligament too short.
$\mathrm{C}=$ specimen too thin.
$D, \Gamma=$ insufficient crack-jump length.

NOTE :

$$
\begin{aligned}
\mathrm{K}_{\mathrm{a}}= & \text { value of stress intensity factor } \\
& \text { shortly after arrest. } \\
\mathrm{RT}_{\mathrm{NDT}}= & \text { reference nil-ductility-transition } \\
& \text { temperature. }
\end{aligned}
$$


Table 8. Unirradiated crack-arrest toughness data obtained from testing weldment $73 \mathrm{~W}$ $\left(\mathrm{RT}_{\mathrm{KDT}}=-34^{\circ} \mathrm{C}\right)$

\begin{tabular}{lccc}
\hline Specimen & $\begin{array}{c}\text { Test } \\
\text { temperature } \\
\left({ }^{\circ} \mathrm{C}\right)\end{array}$ & $\mathrm{K}_{\mathrm{a}}$ & Validity \\
& $(\mathrm{MPa} \cdot \sqrt{\mathrm{m}})$ & \\
\hline
\end{tabular}

Weld-embrittled $25 \times 76 \times 76 \mathrm{~mm}$ specimens

$\begin{array}{llll}\text { A73W38 } & -62 & 50 & \text { A } \\ \text { A73W42 } & -60 & 58 & \\ \text { A73W32 } & -59 & 56 & \text { A } \\ \text { A73W36 } & -59 & 72 & \\ \text { A73W01 } & -45 & 52 & \\ \text { A73W02 } & -45 & 75 & \\ \text { A73W03 } & -45 & 64 & \text { A, B } \\ \text { A73W06 } & -35 & 83 & \text { B } \\ \text { A73W04 } & -30 & 67 & \\ \text { A73W05 } & -30 & 70 & \text { A, B }\end{array}$

Weld-embrittled $25 \times 152 \times 152 \mathrm{~mm}$ specimens

$\begin{array}{llrl}\text { A73W28 } & -61 & 69 & \\ \text { A73W43 } & -45 & 73 & \\ \text { A73W47 } & -45 & 85 & \\ \text { A73W30 } & -44 & 71 & \\ \text { A73W11 } & -32 & 85 & \\ \text { A73W48 } & -31 & 75 & \\ \text { A73W50 } & -30 & 80 & \\ \text { A73W16 } & -29 & 89 & \\ \text { A73W52 } & -29 & 77 & C \\ \text { A73W20 } & -16 & 126 & \text { B,C } \\ \text { A73W25 } & -15 & 141 & \end{array}$

Weld-embrittled $33 \times 152 \times 152 \mathrm{~mm}$ specimens

$\begin{array}{lrrr}\text { A73W29 } & -30 & 100 & \\ \text { A73W10 } & -16 & 77 & \text { A } \\ \text { A73W22 } & -16 & 110 & \\ \text { A73W46 } & -15 & 124 & \\ \text { A73W44 } & -15 & 123 & \\ \text { A73W49 } & -15 & 117 & \\ \text { A73W24 } & -13 & 89 & \text { A, B } \\ \text { A73W27 } & -12 & 111 & \end{array}$


Table 8. (continued)

\begin{tabular}{|c|c|c|c|}
\hline Specimen & $\begin{array}{l}\text { Test } \\
\text { temperature } \\
\left({ }^{\circ} \mathrm{C}\right)\end{array}$ & $\begin{array}{c}\mathrm{K}_{\mathrm{a}} \\
(\mathrm{MPa} \cdot \sqrt{\mathrm{m}})\end{array}$ & Validity ${ }^{a}$ \\
\hline
\end{tabular}

$\begin{array}{lrrr}\text { A73W86 } & -5 & 101 & \\ \text { A73W07 } & 5 & 129 & \text { B } \\ \text { A73W08 } & 5 & 119 & \\ \text { A73W09 } & 5 & 112 & \\ \text { A73W85 } & 5 & 137 & \text { C, D } \\ \text { A73W87 } & 5 & 113 & \\ \text { A73W88 } & 15 & 132 & \end{array}$

Duplex $51 \times 203 \times 203 \mathrm{~mm}$ specimen

\begin{tabular}{l} 
A73W75 507 \\
\hline Oone or inore letters for a specimen \\
indicate that the test results did not met one \\
of the minimum lengths of the ASTM E 1221-88 \\
validity criteria. The letters correspond to \\
those in Table 2 of ASTM E 1221-88, which can \\
be paraphrased as:
\end{tabular}
$A, B=$ unbroken ligament too short.
$C$ - specimen too thin.
$D, E=$ insufficient crack-jump length.

NOTE:

$K_{a}=$ value of stress intensity factor shortly after arrest.

$\mathrm{RT}_{\mathrm{NDT}}=$ reference nil-ductility-transition temperature. 


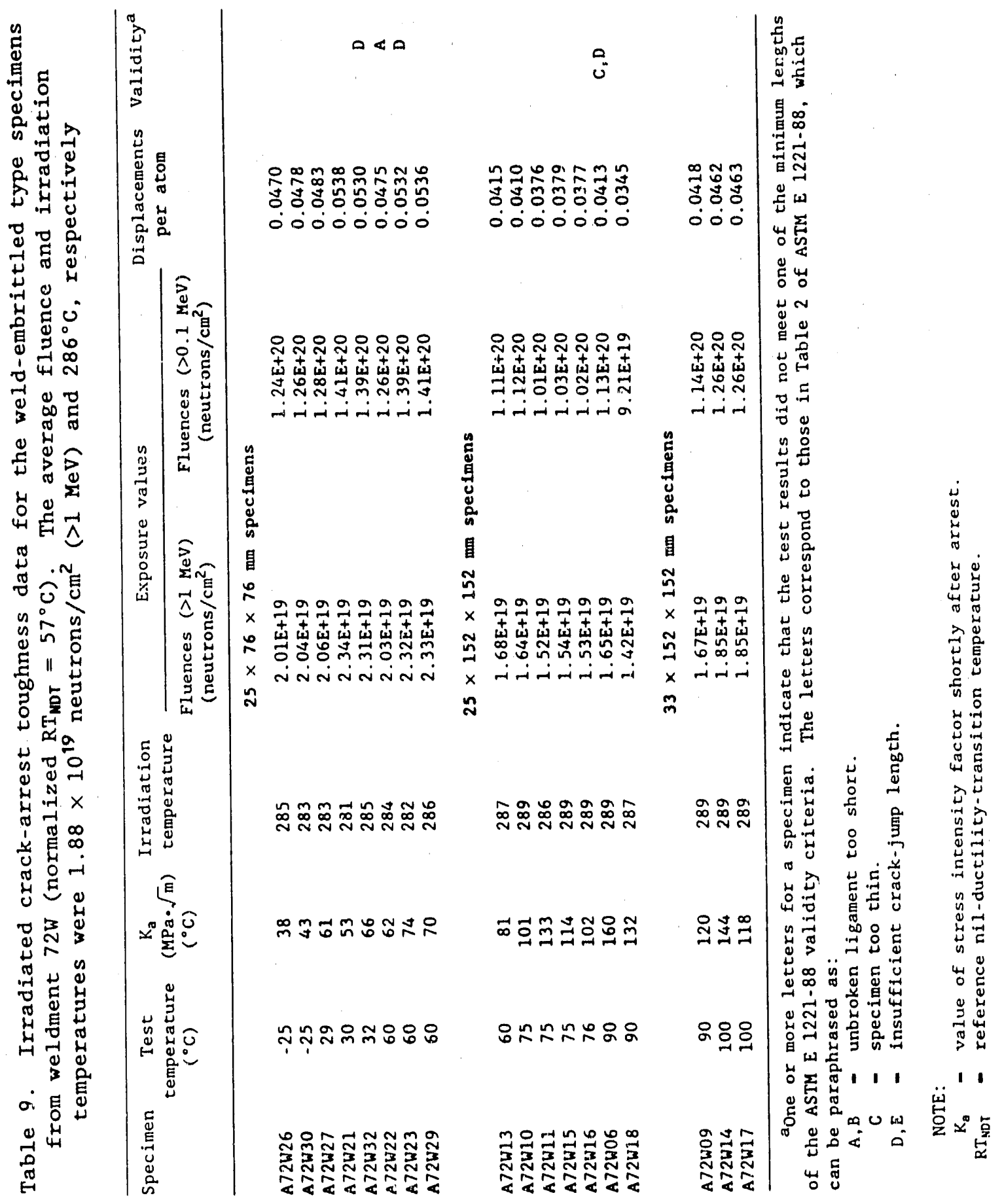




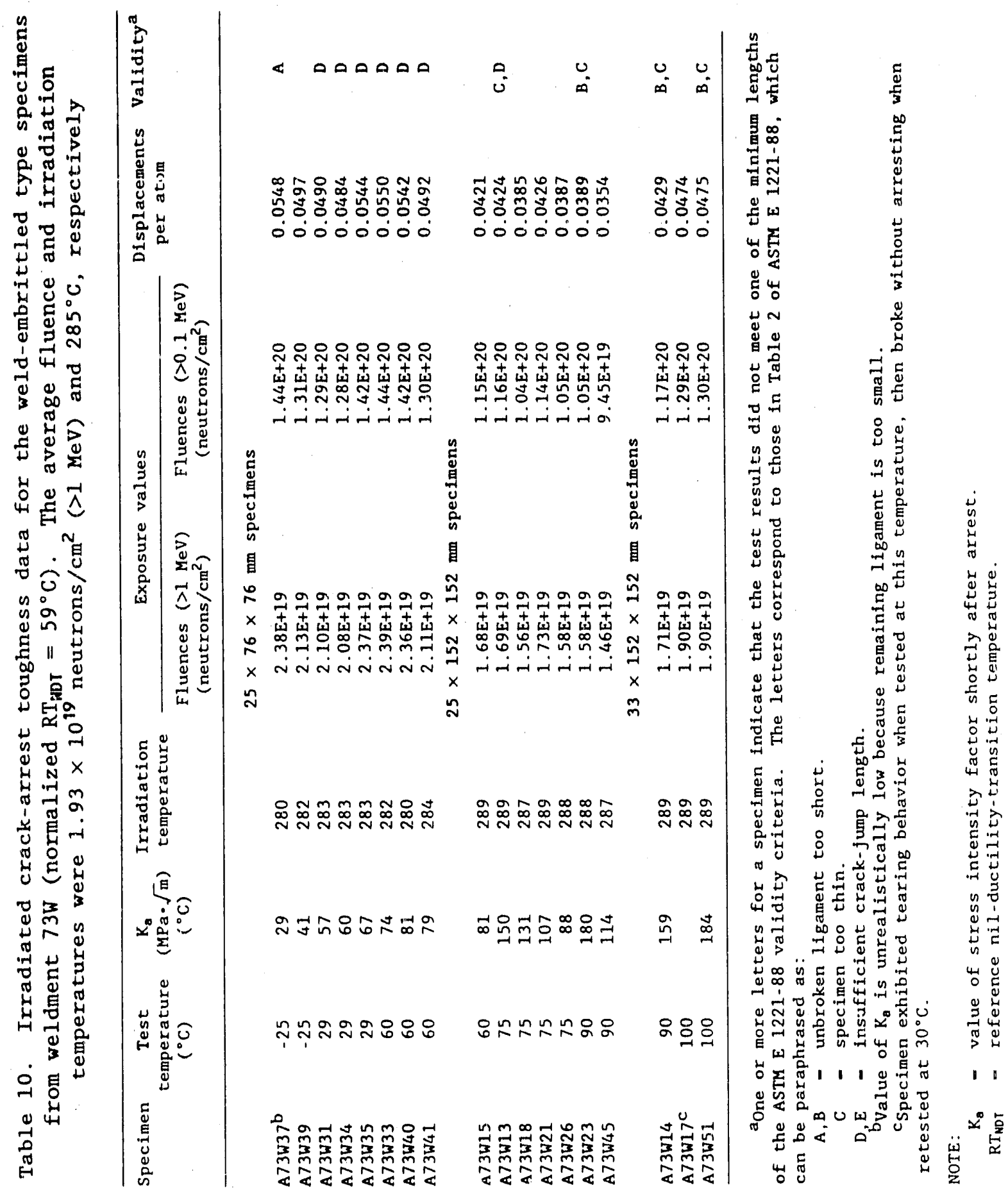


In Tables 7 through 10, the results of the crack-arrest tests that were "invalid" relative to the requirements of ASTM E 1221-88 are indicated by one or more letters, a blank implying a "valid" result. To judge the degree of "invalidity," see the detailed results given in Appendix A.

The crack-arrest toughnesses, $K_{a}$, as a function of test temperature for the different materials, specimen sizes, and specimen types are plotted in Figs. 15 through 18. Comparisons of the unirradiated and irradiated crack-arrest toughnesses for each of the $72 \mathrm{~W}$ and $73 \mathrm{~W}$ welds are shown in Figs. 19 and 20, respectively. These figures also show the unirradiated and irradiated ASME $\mathrm{K}_{\mathrm{I}}$ curves for each weldment indexed to their respective $\mathrm{RT}_{\mathrm{NDT}}$ values. In the plots showing the results of the irradiated crack-arrest testing for weldment $73 \mathrm{~W}$, the data point at $-25^{\circ} \mathrm{C}$ below the ASME $K_{I a}$ curve is that of specimen A73W37, described above.

Lower-bound curves to the test results have been plotted as dotted curves in Figs. 19 through 21. The dotted curves are ASME curves that have been shifted downward in temperature until the first data point is encountered. The amount of the shift is shown for both the unirradiated and irradiated conditions. In the case of $72 \mathrm{~W}$, the temperature shift downward from the normalized curve for the irradiated specimens is $8 \mathrm{~K}$ smaller than that for unirradiated specimens. For the $73 \mathrm{~W}$ specimens, however, the opposite is cbtained; the downward shift for the irradiated specimens results is $11 \mathrm{~K}$ greater than that for the unirradiated specimens. With all the uncertainties involved, the differences between the downward shifts are not deemed to be significant. Thus, the preliminary observation is that the shift in $k_{a}$ due to irradiation is about the same as the shift in the CVN-impact energy at the $41-\mathrm{J}$ energy level, as can be judged by the dotted curves in Figs. 19 and 20 .

All the crack-arrest toughnesses, both unirradiated and irradiated, for both welds have been plotted as a function of $T-R T_{N D T}$ in Fig. 21. The irradiated specimen A73W17 described above (whose remaining ligament was too small to yield an accurate result) is not included in this figure. Figure 21 includes a total of 77 unirradiated and 34 irradiated data points, many of which overlap. This figure indicates that the results form a reasonable trend when indexed to $\mathrm{RT}_{\mathrm{NDT}}$. The normalized $\mathrm{RT}_{\mathrm{NDT}} \mathrm{S}$ (Table 6) have been used to index the irradiated data. When shifted by the normalized CVN $\triangle \mathrm{TT}_{41-\mathrm{J}}$, the ASME curve is a conservative estimate of the irradiated crack-arrest toughness of the $72 \mathrm{~W}$ and $73 \mathrm{~W}$ weldments in the transition region to approximately $40 \mathrm{~K}$ above $\mathrm{RT}_{\mathrm{NDT}}$. At temperatures below $\mathrm{RT}_{\mathrm{NDT}}$, there seems to be a smaller $\mathrm{K}_{\mathrm{Ia}}$ margin between the lower-bound curves and the ASME $K_{I a}$ curves.

The shape of the lower-bound curves shown dotted in Figs. 19 and 20 for the data obtained in Phase 1 of the Sixth Irradiation Series do not seem to have been altered by irradiation. The CVN-impact energy curve for both welds, especially for $73 \mathrm{~W}$, changed shape when irradiated to a 


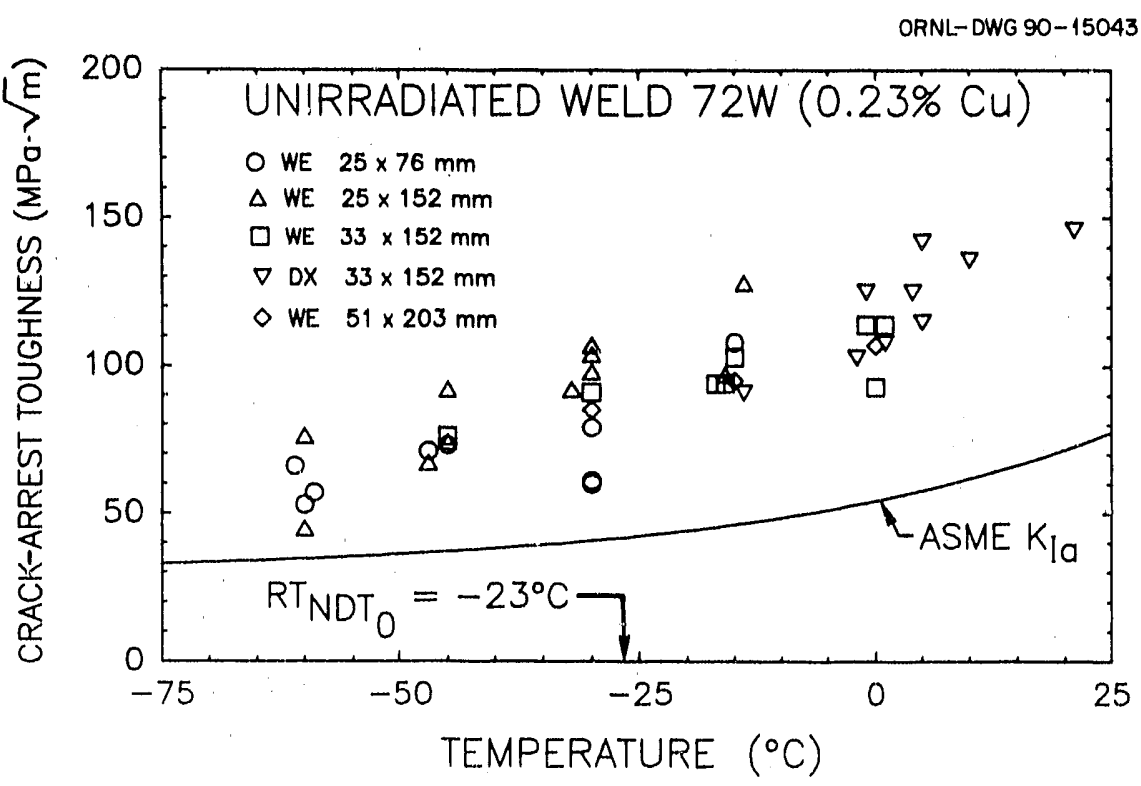

Fig. 15. Detailed crack-arrest toughness $\mathrm{K}_{\mathrm{a}}$ vs test temperature for the unirradiated $72 \mathrm{~W}$ weld showing the different specinen sizes and types used.

DRNL-DWG 90-45044

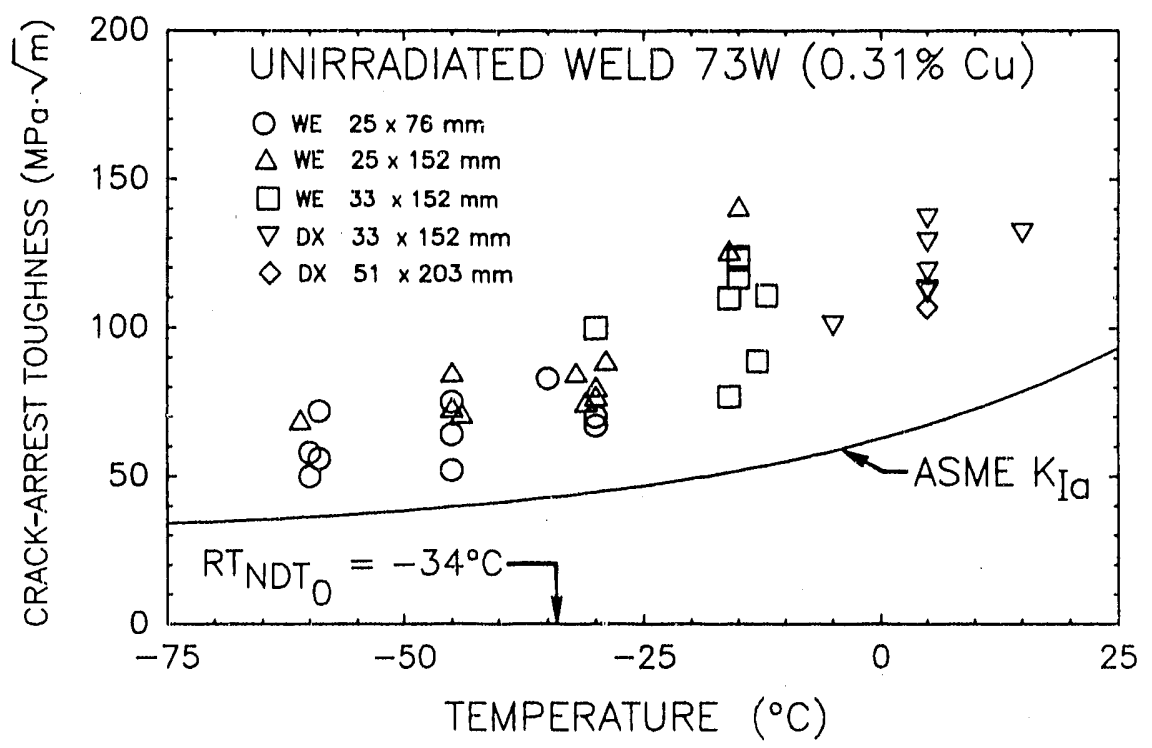

Fig. 16. Detailed crack-arrest toughness $K_{a}$ vs test temperature for the unirradiated $73 \mathrm{~W}$ weld showing the different specimen sizes and types used. 


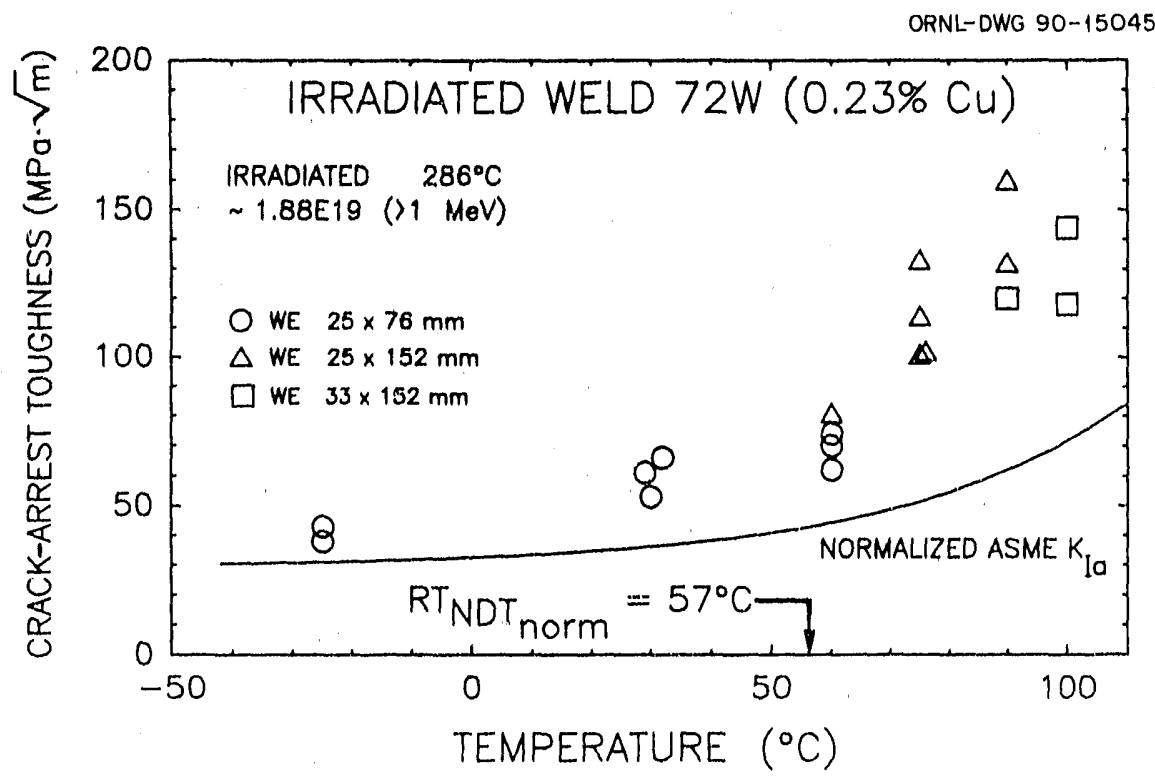

Fig. 17. Detailed crack-arrest toughness $K_{a}$ vs test temperature for the irradiated $72 \mathrm{~W}$ weld showing the different specimen sizes and types used.

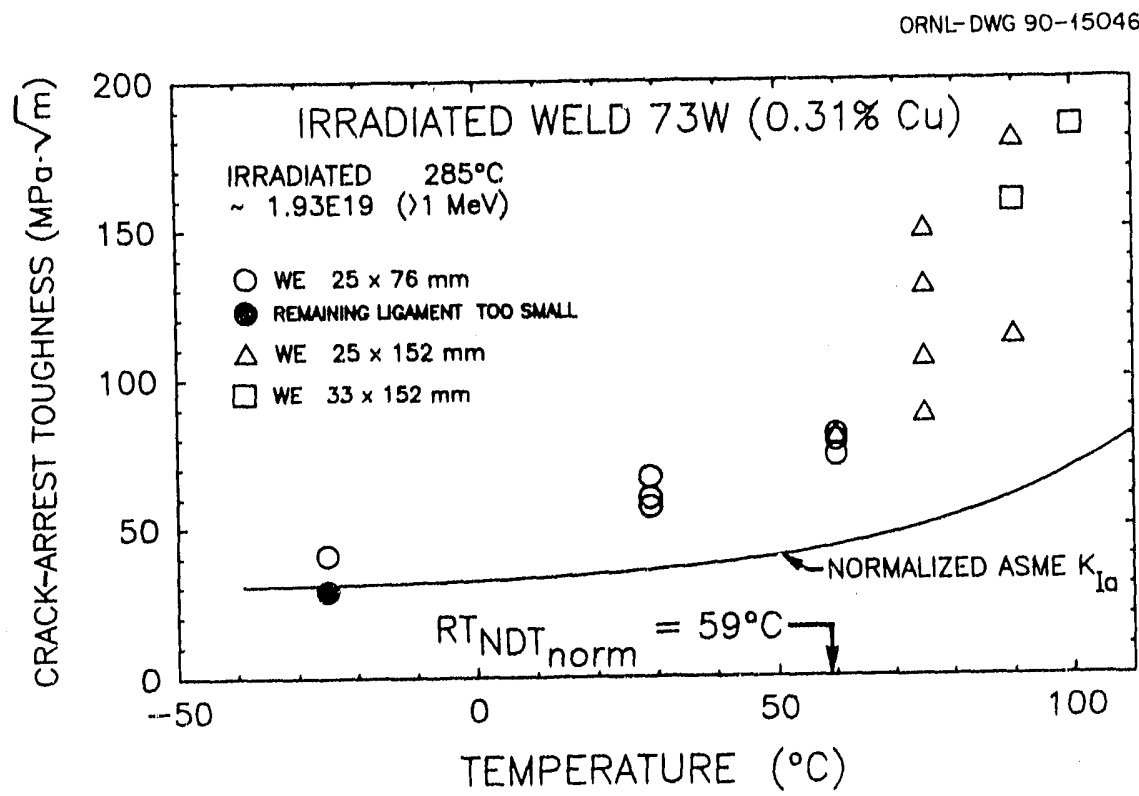

Fig. 18. Detailed crack-arrest toughness $K_{a}$ vs test temperature for the irradiated $73 \mathrm{~W}$ weld showing the different specimen sizes and types used. 
ORNL-DWG 90-11089A

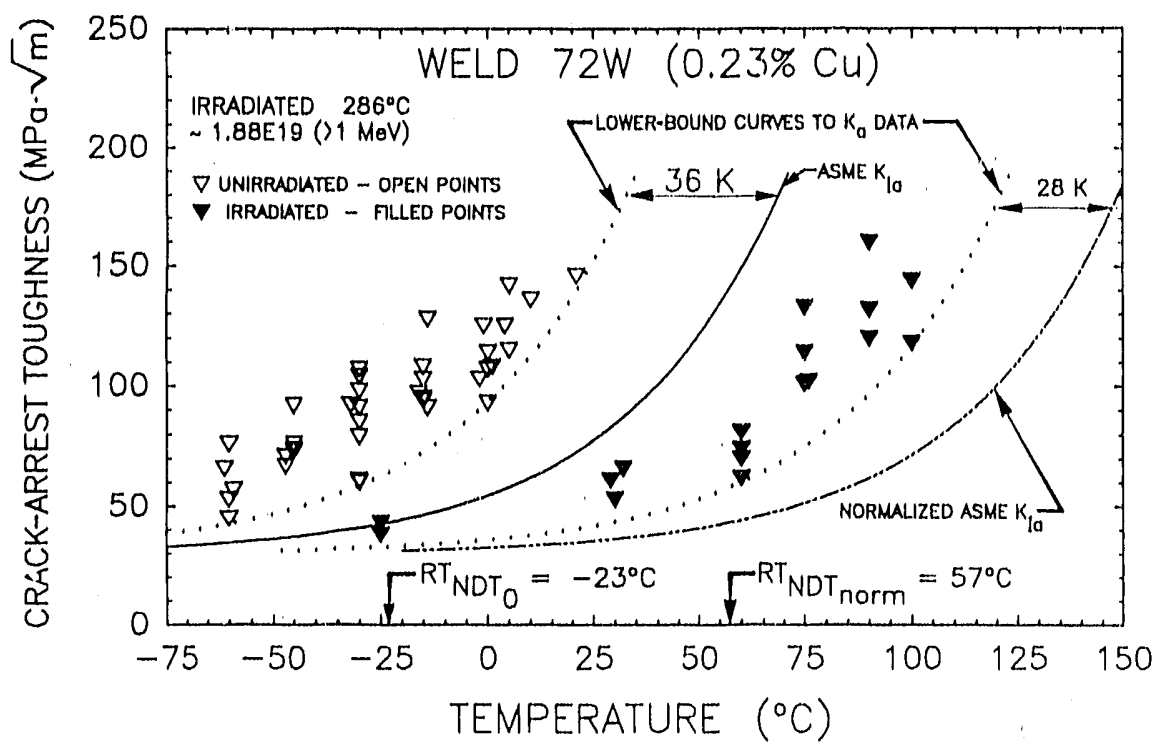

Fig. 19. Unirradiated and irradiated crack-arrest toughness $\mathrm{K}_{\mathrm{a}}$ vs test temperature for the $72 \mathrm{~W}$ weld.

ORNL-DWG 90-11090A

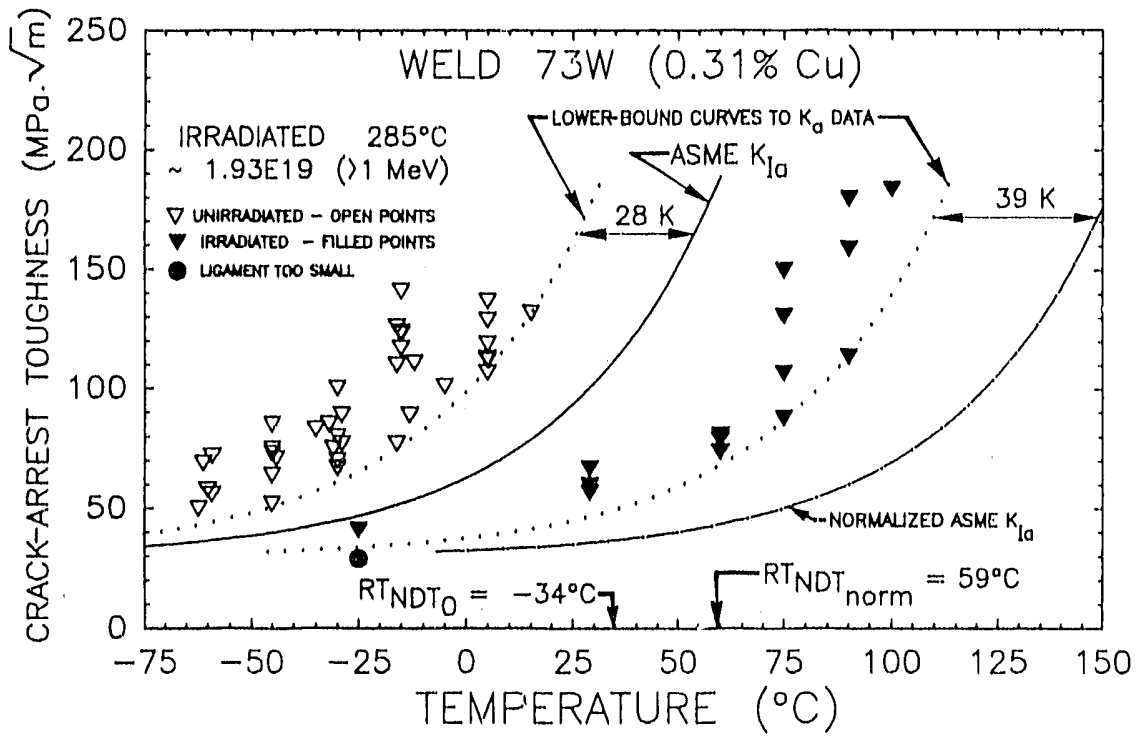

Fig. 20. Unirradiated and irradiated crack-arrest toughness $K_{a}$ vs test temperature for the $73 \mathrm{~W}$ weld. 


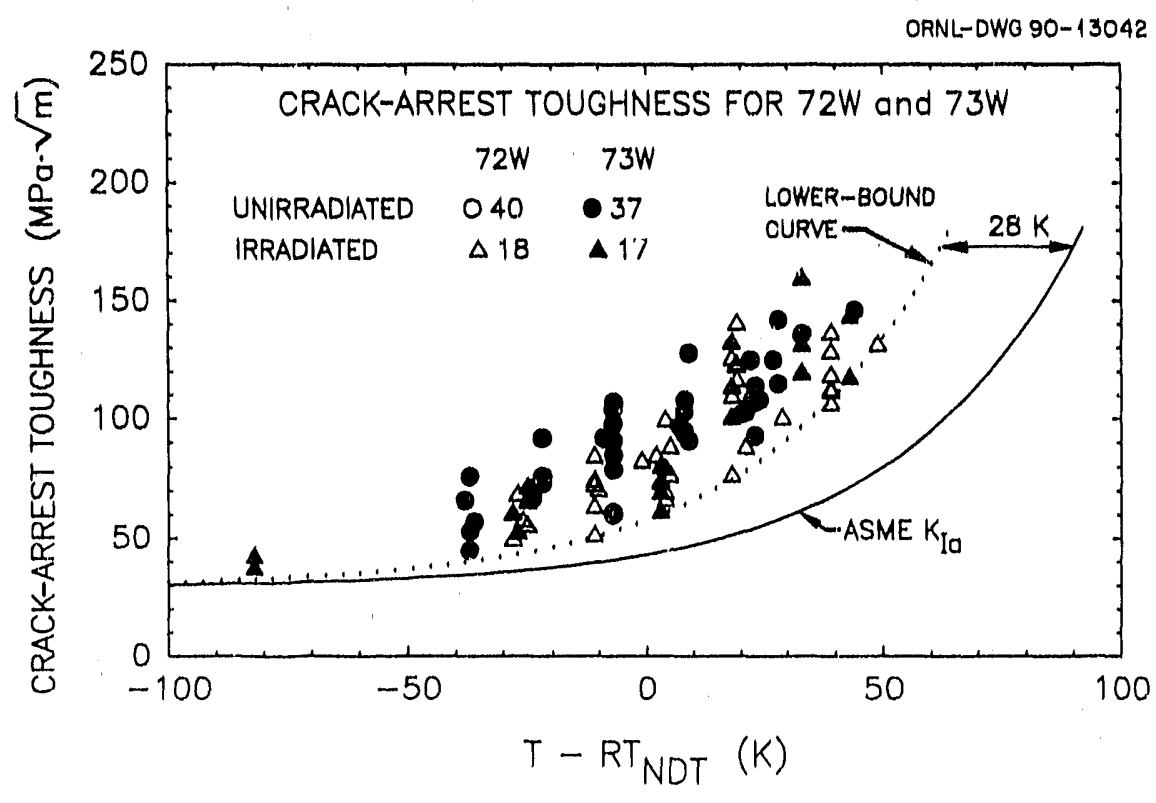

Fig. 21. Al1 crack-arrest toughness $K_{a}$ data for welds $72 \mathrm{~W}$ and $73 \mathrm{~W}$ plotted as a function of $\left(\mathrm{T}-\mathrm{RT}_{\mathrm{NDT}}\right)$.

fluence level of $1.51 \times 10^{19}$ neutrons $/ \mathrm{cm}^{2}$ ( $>1 \mathrm{MeV}$ ), (see Ref, [3] and Fig. 14) Many empirical correlations exist between the CVN-impact energy and fracture toughness of unirradiated ferritic steels (Ref. [9]). If such a relationship also exists for irradiated ferritic steels and if the irradiated CVN curve changes shape, then the irradiated fracture toughness curve may also change shape correspondingly. One of the objectives of the Fifth and Sixth Irradiation Series research programs is to investigate whether irradiation can induce such a shape change in the toughness curves. Indeed, such a change has been observed in the lowerbound curve to the irradiated initiation toughness $K_{J 0}$ data for the $73 \mathrm{~W}$ weldment. Although no such change in shape has been observed in the $k_{a}$ data obtained in tests to approximately $40 \mathrm{~K}$ above $\mathrm{RT}_{\mathrm{NDT}}$, further tests at higher temperatures are needed to ascertain whether a similar change in shape occurs in the arrest toughness curve. Moreover, statistical analyses of all the results will be performed to examine that question.

Successful cleavage crack initiation occurred in 35 of the 36 specimens tested. Such a success rate is unusual even for testing unirradiated specimens. Moreover, successful unstable crack initiation occurred in weld-embrittled-type specimens at test temperatures $40 \mathrm{~K}$ above NDT. A test temperature of approximately $20 \mathrm{~K}$ above NDT is generally considered to be the upper limit for a successful unstable crack to initiate in unirradiated weld-embrittled-type crack-arrest specimens for the steels and specimen thicknesses used here. It is likely that the radiation-induced increases in strength of the test material. and the brittle-weld crack-starter material allows for a higher crack-driving force to enable testing at higher temperatures. 


\section{COMPARISON WITH OTHER DATA}

Reference [2], which describes an Electric Power Regearch Institute (EPRI) project, contains almost all the published data on the effect of irradiation on crack-arrest toughness. Four steels were tested in the EPRI profect: two welds and two plate materlals. Both the plates and the welds included a low-copper as well as a high-copper steel. The total number of irradiated data points from all materials is 34 . The results of the irradiated crack-arrest toughness tests were compared with the unirradiated data by shifting the irradiated data downward in temperature to achieve an approximate data colncidence. The EPRI downward shift is approximately comparable to the lower-bound shift that we used (obtained by shifting the ASME $K_{I_{\text {a }}}$ curve downwards in temperature until the first. data point was encountered). The EPRI shift in $K_{I a}$ due to irradiation for high-copper materials is less than $\Delta \mathrm{TT}_{41-J}$, whereas the shift in $\mathrm{K}_{\mathrm{I}}$ for the low-copper materials is slightly greater or equal to $\Delta \mathrm{TT}_{41-\mathrm{J}}$ (in the EPRI program, the CVN shifts were also evaluated in several other ways). A similar trend is obtained in this study, although the range of copper contents is quite different. In the EPRI program, the copper contents ranged from approximately 0.03 to 0.23 by weight. In our study, the copper contents for the two materials were 0.23 and 0.318 and the normalized $\Delta \mathrm{TT}_{41-\mathrm{J}}$ values were 80 and $93 \mathrm{~K}$, the shifts of the lower-bound $K_{a}$ curves were 88 and $82 \mathrm{~K}$ for the $72 \mathrm{~W}$ and $73 \mathrm{~W}$ welds respectively. We also increased the maximum values of frradiated crack-arrest toughness obtained when compared with those of the EPRI program from approximately 130 to $185 \mathrm{MPa} \cdot \sqrt{\mathrm{m}}$. Irradiated crack-arrest toughness data for both welds in our study were also obtained at higher temperatures with respect to the normalized adjusted $\mathrm{RT}_{\mathrm{KDT}}$ (up to $40 \mathrm{~K}$ above $\mathrm{RT}_{\mathrm{NDT}}$ ) than were the EPRI data for the high-copper weld (up to approximately the adjusted $\mathrm{RT}_{\mathrm{NDT}}$ ). 


\section{SUMMARY}

Cxack-arrest testing of high-copper, submerged-arc welds wass performed on unfrradiated and irradiated weld-embrittled-type specimens 25. and $33 \mathrm{~mm}$ thick. Most of the crack-arrest test results are oither valid or only marginally invalid according to ASTM E 122.1.88. The 35 data polnts obtained by testing the irradiated crack-arrest specimens have approximately doubled the known data base of irradiated crack-arrest toughness and extended the data base coverage to higher levels of crackarrest toughness and temperature relative to $\mathrm{RT}_{\text {NDT }}$. Preliminary observa. tions are:

1. Values of irradiated crack-arrest toughness $K_{I a}$ were obtained at temperatures $40 \mathrm{~K}$ above the irradiated $\mathrm{RT}_{\mathrm{NDT}}$ of the welds. This accomplishment is experimentally significant because a tempexature of $20 \mathrm{~K}$ above $\mathrm{RT}_{\mathrm{NDT}}$ is generally considered to be the linit for obtaining useful results with the unirradiated weld-embrittled type of crack-arrest specimen.

2. The shifts of the lower-bound $K_{a}$ curves for the $72 \mathrm{~W}$ and $73 \mathrm{~W}$ welds are approximately the same as the corresponding $41-\mathrm{J}$ CVN-impact. energy level shifts.

3. The ASME $K_{I a}$ curve, when shifted by $\triangle \mathrm{TT}_{41-J}$, is a conservative estimate of the irradiated crack arrest toughness for welds $72 . \mathrm{W}$ and $73 \mathrm{~W}$ in the transition region $40 \mathrm{~K}$ above $\mathrm{R}^{\mathrm{T}} \mathrm{ND}_{\mathrm{ND}}$. At temperatures below $\mathrm{RT}_{\mathrm{NDT}}$, a smaller margin of toughness is apparent between the lowerbound curves and the ASME $K_{I a}$ curves.

4. The shape of the lower-bound curves compared to those of the ASME $K_{1 a}$ curves were apparentiy unaltered by irradiation for the temperature range covered by the tests. 


\section{ACKNOWLEDGMENTS}

In a project of this magnitude, it is difficult to acknowledge the contribution of the large number of individuals involved. The following Individuals not only contributed to the various tasks mentioned but also mad" many useful suggestions. The authors acknowledge Eri.c T. Manneschmidt, J. Hoyt Mason, Jr, and John J, Henry, Jr, for testing; Thomas D. OwIngs for specimen fabrication and test fixture assembly and shakedown; Ronald L. Swain and David Thomas for assistance with equipment; Lloyd Turner for coordination of activities in the hot cell; Kenneth $W$. Boling for the origlnal design and Bill H. Grubb for modifications of the test fixture durlng shakedown and for the design and manufacture of a $\mathrm{jig}$ for transporting irradiated specimens; Holly Neu and Donna Balltrip for manuscript preparation; and David J. Alexander and Roger E. Stoller for thedr helpful reviews. The authors would like to acknowledge the support and encouragement of Milton Vagins during the initial phases of this project.

The authors also acknowledge Frank B. Kam for dosimetry and Ken R. Thoms and Bill $\mathrm{H}$. Montgomery for capsule design and operation respectively.

The authors are also grateful for the financial support and encouragement from the Nuclear Regulatory Commission (NRC) and Alfied Taboada, the current NRC technical monitor. 


\section{REFIURENCES}

1. C. W. Marschall and A, R, Rosenfleld, "Crack-Arrest Tests of Irradiated High-Copper ASTM A508 Submerged-Arc Weld Metal," pp. 2467-75 in Internationa1 Conference on Fracture, Advances in Fracture Research, Vol. 5, Apri1 1981.*

2. T. R. Mager and C. W. Marschal1, Electric Power Research Institute, Palo Alto, Calif, , Development of Crack Arrest Toughness Data Bank for Irradiated Reactor Pressure Vessel Materials, EPRI NP.3616, July 1984.

3. R. K. Nanstad et al, "Effects of Irradiation on $K_{I}$ Curves for High-Copper Welds," pp. 214-33 in Effects on Radiation on Materials, 14 th International Symposium, ASTM STP 1046, Vo1. II, ed. N. H. Packan, R. E. Stoller, and A. S. Kumar, American Soclety for Testing and Materials, Philadelphia, 1990.

4. R. K. Nanstad, F. M. Haggag, and S. K. Iskander, "Radiation-Induced Temperature Shift of the ASME $K_{I 0}$ Curve," pp. 143-48 in Transactions of the 10th International Conference on Structural Mechanics in Reactor Technology (SMiRT), Vol. S, ed. H. Hadgjian, Anaheim, Cal1f., August 1989.*

5. W. L. Server, J. W. Sheckherd, and R. A. Wullaert, Electric Power Research Institute, Palo Alto, Calif., Fracture Toughness Data for Ferritic Nuclear Pressure Vessel Materials, EPRI NP-119, April 1976.

6. G. R. Odette and G. E. Lucas, "Irradiation Embrittlement of Reactor Pressure Vessel Steels: Mechanisms, Models, and Data Correlations," pp. 206-41 in Radiation Embrittlement of Nuclear Pressure Vessel Steels: An International Review, Second Volume, ASTM STP 909, ed. L. E. Steel, American Society for Testing and Materials, Philadelphia, 1986.

7. D. B. Barker et al., Martin Marietta Energy Systems, Inc., Oak Ridge Nat1. Lab., Oak Rildge, Tenn., A Report on the Round Robin Program Conducted To Evaluate the Proposed ASTM Standard Test Method for Determining the Plane-Strain Crack-Arrest Fracture Toughness, $K_{\text {Ia }}$, of Ferritic Materials, USNRC Report NUREG/CR-4996 (ORNL/Sub/79.7778/4), January 1988. $\dagger^{\dagger}$

8. R. H. Bryan et al., Martin Marietta Energy Systems, Inc, , Oak Ridge Nat1. Lab., Oak Ridge, Tenn., "Pressurized-Thermal-Shock Test of 6in.-Thick Pressure Vesse1s. PTSE-2: Investigation of Low Tearing Resistance and Warm Prestressing," USNRC Report NUREG/CR-4888 (ORNL-6377), December 1987, $\dagger$ 
40

9. S. T. Role and J. M. Barsom, Chap, 6 in Fracture and Fatigue Control in Structures, Prentice-Ha11, Englewood Cliffs, N.J., 1977.

*Available in public technical libraries.

Available for purchase from National Technical Information Service, Springfield, VA 22161. 
APPENDIX A

DETAILED CRACK-ARREST SPECIMEN DATA AND TEST RESULTS 


\section{Flow and Processing of Crack-Arrest Data}

The appendices document for archival and quality assurance purposes various aspects of the crack-arrest data. Appendix A traces the flow and processing of data on the crack-arrest specimens and also gives detailed crack-arrest specimen dimensions and results. The BASIC computer code "CA TEST" used to process the test data is listed in Appendix $B$, and the Young's moduli used are discussed in Appendix $C$. Typical output from CA_TEST for weld-embrittled and duplex-type crack-arrest specimens is shown in Appendix D. The load vs crack mouth opening displacement (CMO:) charts obtained during the test and a photograph of the fracture surfact for each irradiated specimen is reproduced in Appendix E.

It is not p'ssible to legibly present the voluminous data abol each specimen in oire table without orting to coldout pages. Thus, to limit table widths to a single pag-, the data are logically grouped ausl the specimen adentification is used to tie the tables together. To facilitate the: $r$ use, the crack-arrest data tables given in the appendices are sorted by specimen identification (in the main body of the text they are sorted by test temperature).

The dimensions of each crack-arrest specimen are measured and recorded on data sheets, a sample of which is shown in Fig. A.1. The data on crack-arrest specimens are then recorded on a Hewlett packaru Series 200/300 computer. The BASIC computer code used for this purpose is CA_TEST, (çrack arrest test), which was specifically written to process the crack-arrest test data. A listing of CA_TEST is included in Appendix $B$. The pretest input data consist of the measured specimin dimensions, test temperature, yield strength, and Young's modulus at the test temperature. The measured specimen dimensions, for the unirradiated and irradiated crack arrest tests are given in Tables A-1 and A-2, respectively. The yield strength and Young's moduli used have not been included in these tables. The yield strength for each of the $72 \mathrm{~W}$ and $73 \mathrm{~W}$ weldments are presented as Figs. 10 and 11 in the main body of the tes:., and Young's moduli are given in Appendix $C$.

The ASTM E 1221-88 test procedure prescribes for weld-embrittled. type specimens only a series of loading and unloading cycles. The yield strength and Young's modulus are used to calculate the load increment for the loading and unloading cycles for weld-embrittled-type specimens as well as the validity criteria. Young's modulus is also used to evaluate the stress intensity factors.

The pretest output for CA TEST is an echo of the input data. CA TEST also calculates and prints the load increments for the loading and unloading stefs in terms of clip-gage CMOD. For duplex specimens, no loading and unloading cycles are prescribed in ASTM E 1221-88, but a single cycle with a CMOD approximately equal to that for weld-embrittled specimens is performed to seat the clip gage and generally shake down the test equipment. 
After the rapid crack propagation and arrest event, the specimen is heat-tinted, chilled, and broken open. The length of the remaining 1.igament is measured at three locations by the procedure given in paragraph 8.6.2 of E 1221-88. These three lengths as well as the clipgage CMODs at the four points on the load vs CMOD chart as prescribed in ASTM E 1221-88 are provided as posttest input to CA_TEST.

The maximum and minimum loads registered just before and after the rapid crack propagation event are also recorded. During the development of ASTM E 1.221.88, the ratio of these loads was one of the validity requirements. Although the latest revision of ASTM E 1221-88 does not prescribe this ratio, it is still recorded for consistency with the large number of existing files. Experience has also shown that the relative load drop is an approximate indicator of the crack-jump length at the time of the test. A small drop in load is an indication that the crack has not propagated a significant amount. At the other extreme, if the load drops to almost zero, it is likely that the remaining ligament is sma11. All the posttest data are given in Tables A-3 and A-4 for the unirradiated and irradiated specimens respectively.

The output of CA TEST echoes the posttest data input and calculates $\mathrm{K}_{\mathrm{a}}$ and $\mathrm{K}_{\mathrm{o}}$ as we $\bar{l} 1$ as all the validity criteria prescribed in ASTM E 1221.-88. The output also indicates which of the criteria have been met or not met. Typical output from CA_TEST for both a weld-embrittled and a duplex specimen is given in Appendix D.

The detailed values used to determine the validity of the crackarrest results are given in Tables A-5 through A-8. Tables A-5 and A-6 are for the unirradiated $72 \mathrm{~W}$ and $73 \mathrm{~W}$ weldments respectively, and the corresponding information for the irradiated weldments is in Tables A-7 and $A-8$. In these four tables, the first row for each specimen contains the measured values required to judge the validity of the results. Below these values are the corresponding minimum values as prescribed in ASTM E 1221-88. Validity criteria are evaluated for weld-embrittled specimens (4 criteria) and duplex-type specimens ( 5 criteria).

In the right-hand column, the presence of one or more letters indicates that the specimen did not meet the validity criteria of ASTM E 1221-88. The arrested crack front is rarely straight or square. Thus, to allow for uncertainties in the measurement of the remaining ligarient, the measured values were increased by $10 \%$ before they were compared with the ASTM criteria.

Other values included in the tables are the specimen type (whether weld embrittled or duplex) and nominal specimen thickness $B$ and overall width (the height is equal to the width). Other parameters included are test temperature and stress intensity factors just before the rapid crack propagation event $K_{o}$ (a measure of the crack-driving force) and that shortly after arrest $K_{a}$. 
During the processing of the data, it was not clear how the information will be eventually presented. To maintain some flexibility, the data are maintained in the relational data base computer code PARADOX. Such a data base allows any of the information stored in it to be selected, sorted, and formatted for presentation. All data (including that from the Hewlett Packard Series 200/300 computers) are maintained in PARADOX on an IBM-compatible computer. The tables in this report have been prepared by using a RDB computer code. The RDB code has also proven useful in the evaluation of the data. When the data are examined from different viewpoints, input data errors are often noticed. 


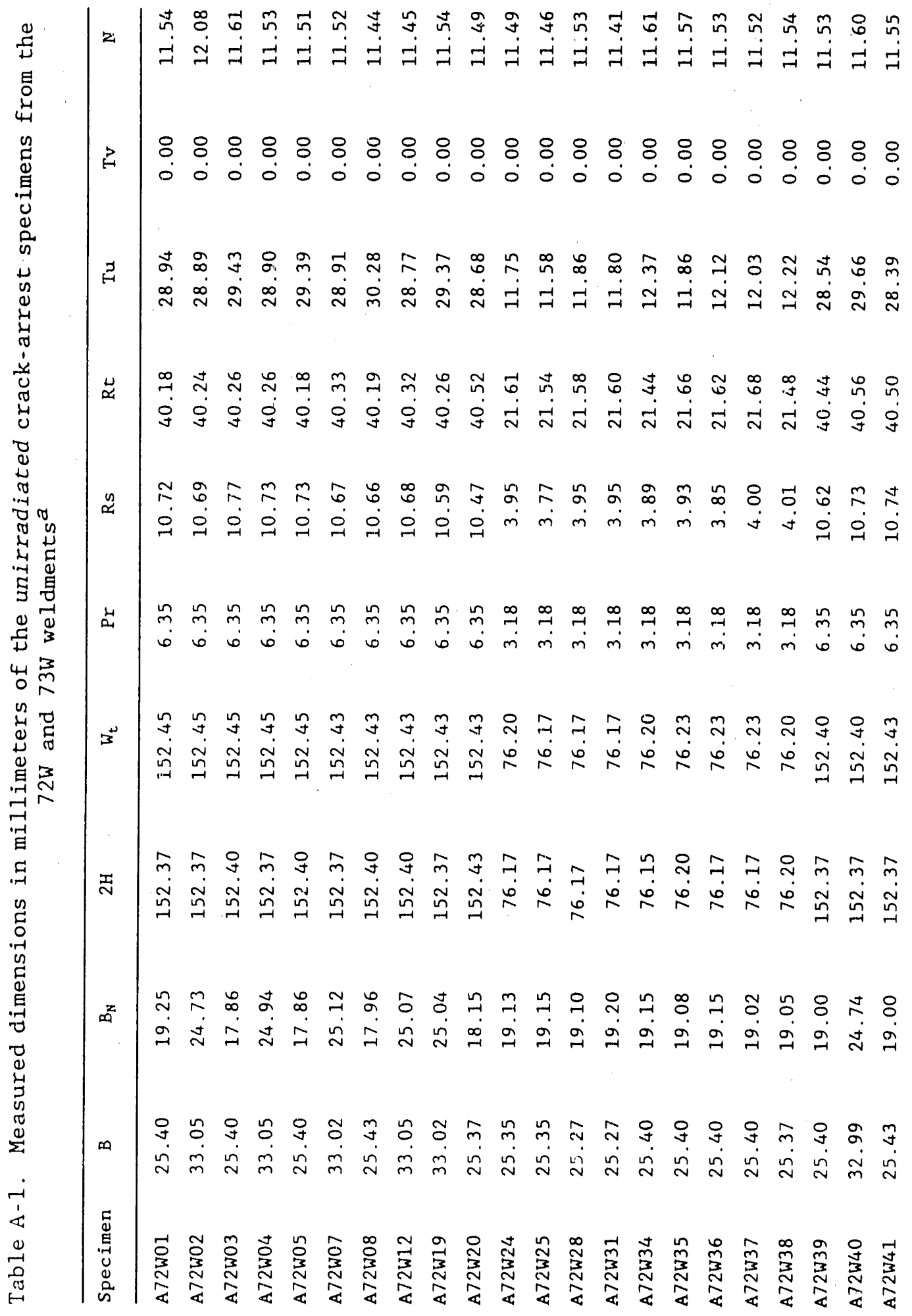




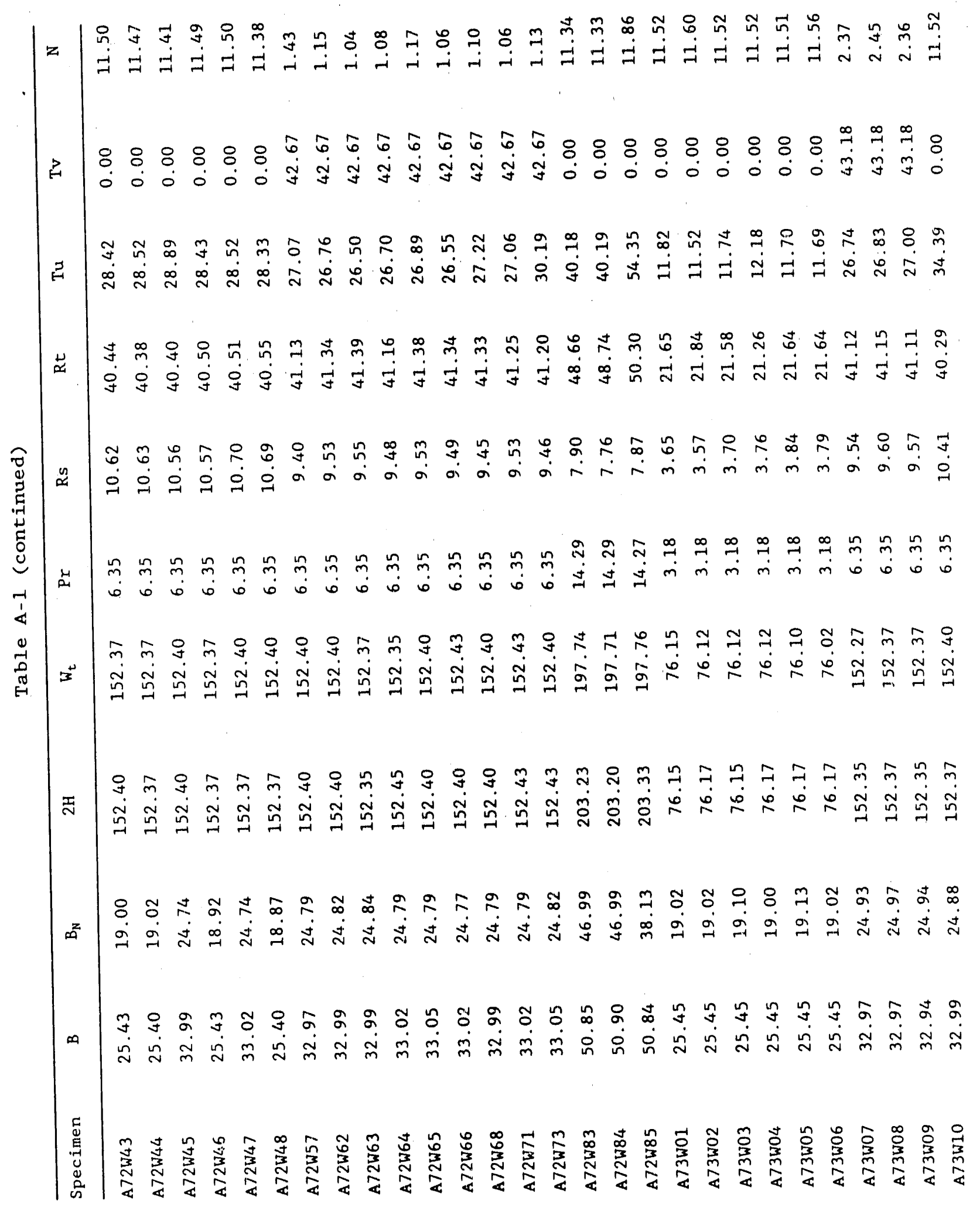




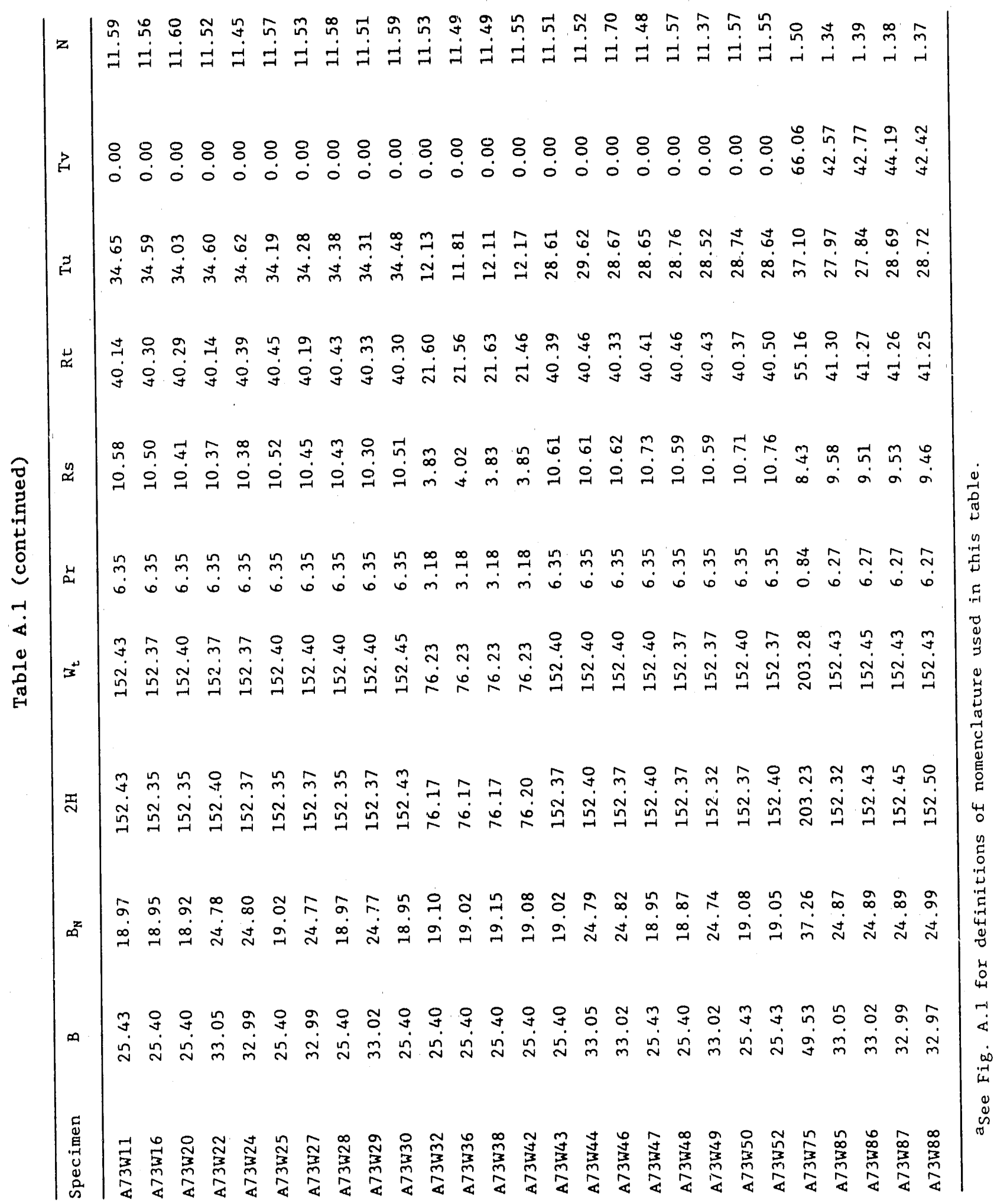




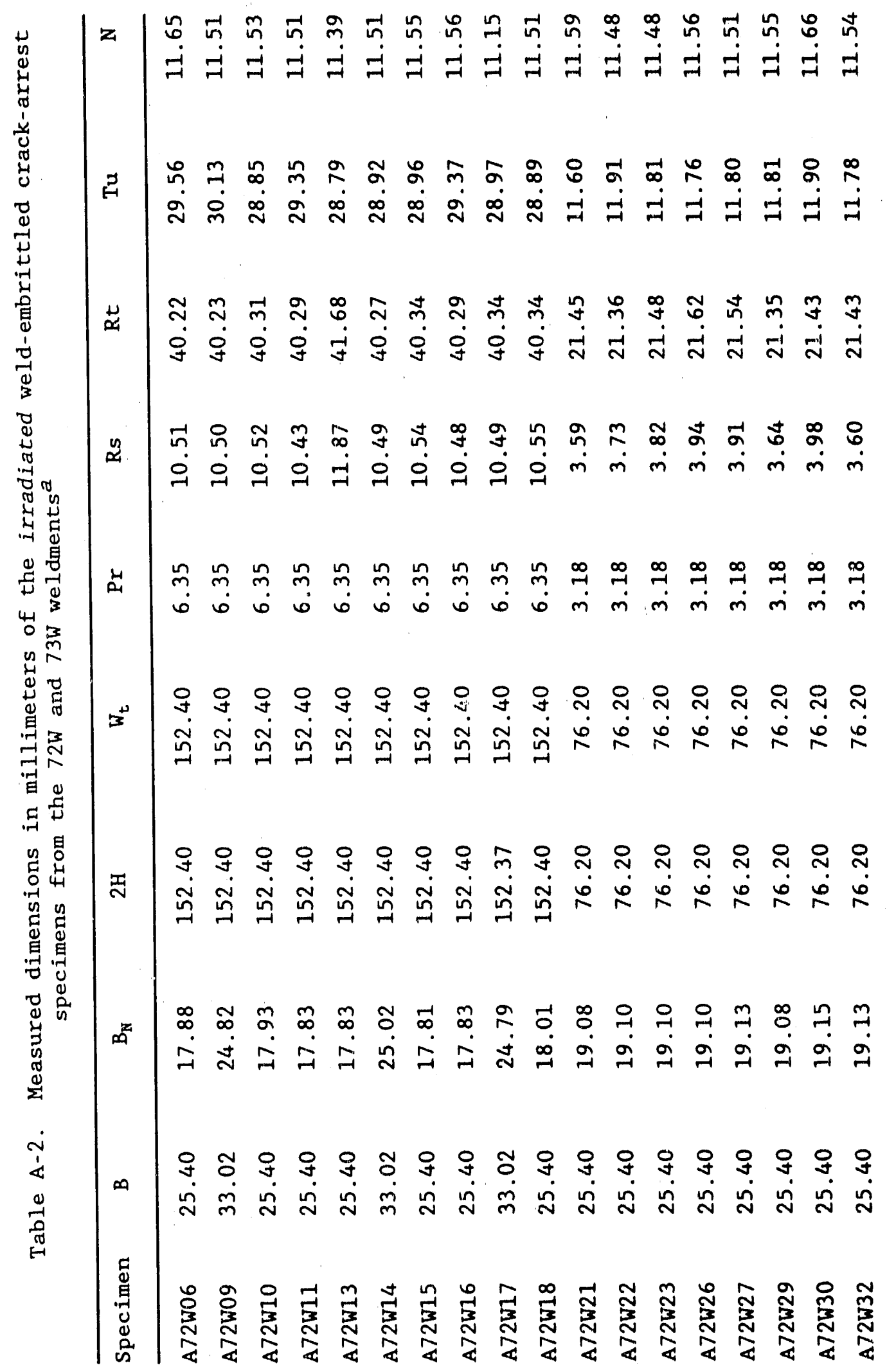




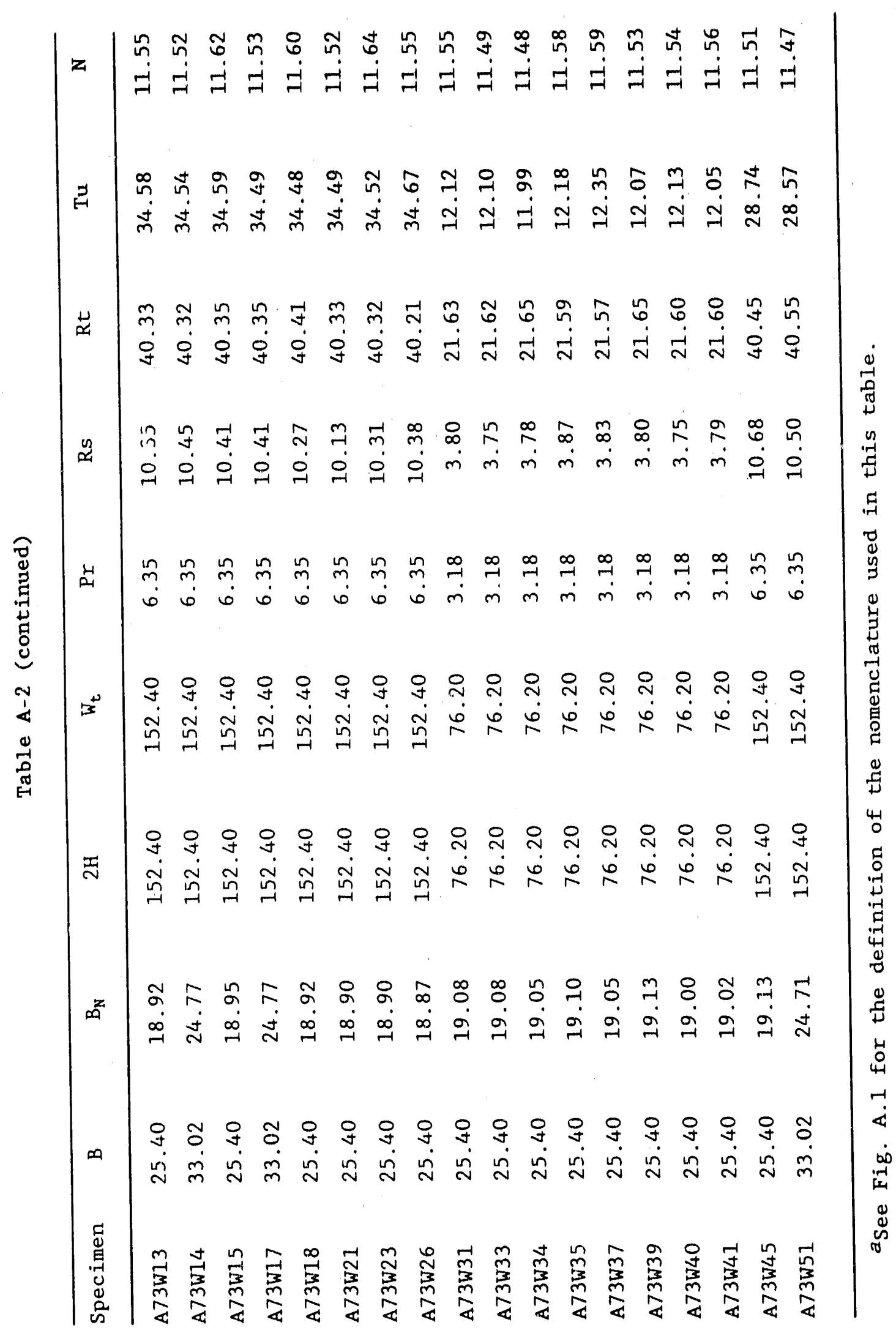


Table A-3. Posttest values measured for unirradlated crack-arrest specimens from the $72 \mathrm{~W}$ and $73 \mathrm{~W}$ weldments

\begin{tabular}{|c|c|c|c|c|c|c|c|c|c|}
\hline specimen & $W 1$ & $W 2$ & W3 & $\mathrm{P} 1$. & $P 2$ & 83 & $P 4$ & $P_{\max }$ & $P_{\min }$ \\
\hline$\Delta 72 W 01$ & 33.01 & 30.94 & 33.66 & 0.056 & 0.163 & 1.351 & 1.369 & 52 & 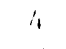 \\
\hline$\$ 72 W 02$ & 28.64 & 27.53 & 29.22 & 0.038 & 0.147 & 1.369 & 1.443 & 11 & 1) \\
\hline A72W03 & 42.67 & 42.52 & 42.70 & 0.051 & 0.165 & 1.405 & 1.455 & $5 / 6$ & 11 \\
\hline A. $2 W 04$ & 27.80 & 25.65 & 31.22 & 0.025 & 0.122 & 1.367 & 1.1445 & 6,8 & $\therefore$ \\
\hline A/2WOS & 36.73 & 36.13 & 42.57 & 0.0146 & 0.165 & 1.265 & 1.326 & 54 & 11 \\
\hline$\therefore / 2 W 07$ & 34.68 & 34.73 & 34.43 & 0.061 & 0.163 & 1.367 & $1 .: 3$ & 73 & $u$ \\
\hline A72W08 & 35.86 & 34.64 & 34.81 & 0.030 & 0.145 & 1.283 & 1.346 & 52 & $i$ \\
\hline$A / 2 W 12$ & 33.03 & 34.23 & 33.78 & 0.038 & 0.312 & 1.600 & 1.651 & 77 & 1 \\
\hline A)2W19 & 33.09 & 36.33 & 33.54 & 0.051 & 0.142 & 1.224 & 1.326 & 11 & 0 \\
\hline$\wedge 72 W 20$ & 39.10 & 35.34 & 42,45 & 0.000 & 0.000 & $0.71 / 4$ & 0.767 & 29 & 0 \\
\hline A72W2.4 & 10.58 & 1.0 .37 & 10.35 & 0.020 & 0.058 & 0.742 & 0.815 & 27 & 0 \\
\hline$\wedge / 2 W 25$ & 12.50 & 11.65 & 14.60 & 0.046 & 0.109 & 0.889 & 0.932 & 26 & $\therefore$ \\
\hline A) $2 W 28$ & 9.82 & 1.0 .54 & 9.45 & 0.018 & 0.079 & 0.762 & 0.828 & 33 & 0 \\
\hline A72W31 & 13.26 & 13.46 & 15.78 & 0.020 & 0.208 & 1.168 & 1.21 .9 & 51 & 1 \\
\hline$\therefore 72 W 34$ & 14.77 & 13.69 & 15.95 & 0.013 & 0.043 & 0.732 & 0.737 & 28 & $?$ \\
\hline$\lambda / 2 W 35$ & 12.02 & 12.56 & 12.14 & 0.008 & 0.020 & 0.554 & 0.630 & 25 & b) \\
\hline$A 72 W 36$ & 13.67 & 14.84 & 11.82 & 0.010 & 0.069 & 0.737 & 0.800 & 31 & $\therefore$ \\
\hline A72W37 & 14.20 & 14.47 & 14.15 & 0.008 & 0.015 & 0.610 & 0.709 & 26 & 1) \\
\hline A72W38 & 11.65 & 11.74 & 11.15 & 0.020 & 0.028 & 0.620 & 0.699 & 2.8 & () \\
\hline$A / 2 W 39$ & $13.8 \%$ & 14.46 & 13.79 & 0.030 & 0.030 & 0.879 & 1.095 & 34 & $" 1$ \\
\hline$\Delta 72 W 40$ & 24.79 & 27.18 & 23.77 & 0.051 & 0.320 & 1.892 & 1.956 & 87 & 1) \\
\hline$A>2 W 41$ & 34.88 & 34.19 & 33.12 & 0.056 & 0.056 & 0.927 & 1.016 & 30 & 1) \\
\hline $172 W 43$ & 33.35 & 31.12 & $3 / 4.07$ & 0.025 & 0.066 & 1.184 & 1.245 & 49 & 11 \\
\hline A72W44 & 34.18 & 34.21 & 33.34 & 0.018 & 0.043 & 0.925 & 1.019 & 144 & 2 \\
\hline$A 72 W 45$ & 38.29 & 38.93 & 36.84 & 0.058 & 0.058 & 0,889 & 0.980 & 38 & $?$ \\
\hline$\Delta 72 W 46$ & 46.44 & 48.73 & 42.19 & 0.056 & 0.056 & 0.958 & 0.980 & 36 & 8 \\
\hline A72W47 & 33.36 & 38.38 & 29.52 & 0.061 & 0.097 & 1.189 & 1.255 & 56 & $?$ \\
\hline$A 72 W 48$ & 34.57 & 35.19 & 33.04 & 0.038 & 0.076 & 1.214 & 1.306 & 33 & 3 \\
\hline A72W57 & 54.48 & 54.34 & 56.69 & 0.018 & 0.000 & 1.283 & 1.316 & 78 & i \\
\hline$A / 2 W 62$ & 37.13 & 37.39 & 36.83 & 0.000 & 0.000 & 1.577 & 1.659 & 107 & 8 \\
\hline$\wedge 72 W G 3$ & 39.81 & 40.04 & 41.37 & 0.005 & 0.000 & 1.361 & 1.42 .7 & 143 & 1 \\
\hline $172 W 64$ & 37.49 & 35.73 & 39.64 & 0.036 & 0.000 & 1.275 & 1.306 & 75 & 10 \\
\hline A72W65 & 34.33 & 34.35 & 38.15 & 0.010 & 0.000 & 1.509 & 1.554 & 84 & 8 \\
\hline
\end{tabular}


Table A-3. (continued)

\begin{tabular}{|c|c|c|c|c|c|c|c|c|c|}
\hline spoctmon & $w 1$ & $W / 2$ & W3 & P1 & $P 2$ & 13 & $p / 4$ & $P_{\max }$ & $I_{\text {InI!n }}$ \\
\hline$\Lambda 12 W 66$ & 31.37 & 32.20 & 30.64 & 0.01 .8 & 0.000 & 1.346 & 1.402 & 87 & 3 \\
\hline A72WG8 & 35.12 & 35.53 & 38.25 & 0,020 & 0.000 & 1.359 & 1.443 & 89 & 1) \\
\hline$A / 2 W 71$ & 23.22 & 22,16 & 25.71 & 0.025 & 0.000 & 1.392 & 1.504 & 106 & 1) \\
\hline$A 72 W 73$ & 48.18 & 50.45 & 43.83 & 0.046 & 0.000 & 1.415 & 1.448 & 6,4 & $i$ \\
\hline A72W83 & 59.33 & 60.56 & 56.02 & 0.079 & 0.079 & 1.209 & 1.2 .2 .4 & 66 & $\because 6$ \\
\hline A) $2 W 84$ & 53.72 & 55.41 & 60.47 & 0.086 & 0.178 & 1.570 & 1.651 & $1: 1$ & $\therefore$ \\
\hline A72WBS & 32.98 & 39.89 & 2.8 .27 & 0.102 & 0.163 & $1.74,5$ & 1.816 & 76 & (1) \\
\hline A\%3W01 & 10.14 & 10.87 & 9.47 & 0.051 & 0.038 & 0.650 & 0.699 & 18 & 0 \\
\hline A73WO2 & 14.24 & 12.53 & 15.76 & 0.025 & 0.038 & 0.732 & 0.808 & 2.7 & 0 \\
\hline ^73WO3 & 7.76 & 7.89 & 8.08 & 0.030 & 0.097 & 0.919 & 0,998 & 26 & 0 \\
\hline A73w04 & 10.36 & 9.00 & 11.43 & 0.030 & 0.102 & 0.838 & 0.909 & 38 & 0 \\
\hline A73WOS & 8.04 & 9.48 & 7.29 & 0.038 & 0.193 & 1.021 & 1.125 & 38 & 0 \\
\hline A73WOG & 12.99 & 1.3 .00 & 12.67 & 0.043 & 0.254 & 0.996 & 1.052 & 37 & ") \\
\hline A73WOT & 30.21 & 34.74 & 31.51 & 0.025 & 0.000 & 1.636 & 1.783 & 119 & 1) \\
\hline A/3WO8 & 39.08 & 38.93 & 40.81 & 0.025 & 0.000 & 1.313 & 1.417 & 88 & 1 \\
\hline A) 3609 & 37.24 & 39.62 & 37.05 & 0.025 & 0.000 & 1.283 & 1.372 & 97 & () \\
\hline A73W10 & 16.62 & 16,62 & 16.31 & 0.030 & 0.229 & 1.605 & 1.671 & 66 & 11 \\
\hline A $73 W 11$ & 34.95 & 33.74 & 36.70 & 0.051 & 0.079 & 1.085 & $1.10 \%$ & 31 & 12 \\
\hline$A / 3 W 16$ & 32.55 & 34.35 & 31.80 & 0.013 & 0.051 & 1.143 & 1.186 & 1.8 & 11 \\
\hline A/3W2O & 140.31 & 40.56 & 39.90 & 0.051 & 0.262 & 1.542 & 1.565 & 49 & ' \\
\hline A73W22. & 2.7 .44 & 26.80 & 29.91 & 0.013 & 0.173 & 1.651 & $1.6 \% 1$ & 54 & () \\
\hline A) $3 W 24$ & 14.07 & 14.66 & 11.93 & 0.038 & 0.361 & 2. 108 & 2.200 & 688 & 1) \\
\hline 173W25 & 35.53 & 35.93 & 39,76 & 0.038 & $0.2 ? 3$ & 1.781 & 1.819 & 48 & $1 \%$ \\
\hline$\wedge 73 W^{\prime} 27$ & 34.23 & 38.29 & 34.82 & 0.025 & $0.12:$. & 1.407 & 1.433 & 61 & 0 \\
\hline A73W:8 & 29.54 & 30.73 & 28.66 & 0.051 & $0.05:$ & 0.968 & 1.003 & 30 & ? \\
\hline$\wedge 73 w 29$ & 31.24 & 26.85 & 34.02 & 0.064 & i). 099 & 1,402 & 1.4 .33 & 66 & 0 \\
\hline Aา3W36 & 25.60 & 28.52 & 23.98 & 0.025 & 0.053 & 1.067 & 1.118 & 31 & 0 \\
\hline A) $3 W 32$ & 6.60 & 6.91 & 6.93 & 0.013 & 0.058 & 0.841 & 0.927 & 37 & () \\
\hline A736? & 13.84 & 13.75 & 12.90 & 0.013 & 0.043 & 0.110 & 0.792 & 31 & 1 \\
\hline A73W38 & 6.98 & 6.83 & 6.81 & 0.020 & 0.048 & 0.699 & 0.876 & 2.3 & 1) \\
\hline A73 3642 & 8,80 & 8.09 & 9.36 & 0.025 & 0.053 & 0.726 & 0.874 & 34 & () \\
\hline A73W4 3 & 35.72 & 36.16 & 36.54 & 0.056 & 0.056 & 0.892 & 0.968 & 43 & 0 \\
\hline A) $3 W 44$ & 111.77 & 44.87 & 42.95 & 0.064 & 0.150 & 1.372 & 1.433 & 75 & 18 \\
\hline A73W46 & 41.28 & 39.15 & 42.24 & 0.030 & 0.137 & 1.433 & 1.473 & 73 & 0 \\
\hline A73W47 & 39.58 & $1,1.03$ & 39.26 & 0.056 & 0.056 & 0.968 & 1.031 & 38 & 9 \\
\hline A73W48 & 28.27 & 26.48 & 29,53 & 0.051 & 0.091 & 1.090 & 1.166 & 40 & 3 \\
\hline 173649 & 35.39 & 33.42 & 38.65 & 0.030 & 0.206 & 1.516 & 1.539 & 6,34 & 11 \\
\hline
\end{tabular}


Table A-3, (continued)

\begin{tabular}{|c|c|c|c|c|c|c|c|c|c|}
\hline speolmen & $W L$ & W2 & W3 & $P 1$ & $1+1$ & 83 & $\mathrm{pl}$ & $P_{\text {max }}$ & $I_{\min }$ \\
\hline Ä3WS & 18,05 & 18.28 & 22,52 & 0.036 & 0,232 & 1.435 & 1,560 & 67 & 1) \\
\hline A7:452 & 18.32 & 18.84 & 17,84 & 0.051 & 0.135 & 1.448 & 1.567 & 66 & () \\
\hline A73:175 & 40,84 & 37.67 & 45.12 & 0.000 & 0.000 & 1.613 & 1,765 & 181 & () \\
\hline $173 k 85$ & 50.63 & 50.28 & 49,94 & 0.000 & 0.000 & 1.280 & 1,313 & 82 & 1 \\
\hline A7 JWA 6 & 34,19 & 35.10 & 32.86 & 0.000 & 0.000 & 1.245 & 1.285 & 83 & 1 \\
\hline A73W87 & 30.58 & 30,94 & 30.74 & 0,000 & 0.000 & 1.491 & 1.554 & 91 & $\%$ \\
\hline A73W68 & 42.81 & 46,58 & 42,56 & 0.000 & 0.0011 & 1.387 & 1.407 & 82 & 3 \\
\hline
\end{tabular}

NOTES:

W1, W2, and W3 - Lengths in m1l1Lneters of the romalning LIgament measurod accordlng, to ASTM E 1221.88

P1 through $P A$ - displacoments in ml111meters measured from the load va CMOD traca, see $F[g, A, 3$.

$P_{\max }, P_{\min }=$ maximum and minimum loads regiatered fust before and fust after the rapid crack. propagation event. 
Table A-4. Posttest values measured for unfrradlated crack arrest specimens from the $72 \mathrm{~W}$ and $73 \mathrm{~W}$ weldments

\begin{tabular}{|c|c|c|c|c|c|c|c|c|c|}
\hline Spaciman & $W 1$ & W'2 & W' & $\mu 1$ & $\mathrm{PL}$ & $\mathrm{P3}$ & $11 / 4$ & $I_{\max }$ & $P_{m+11}$ \\
\hline$\Lambda \div 2 W 06$ & $0,6.1$ & 67.45 & $0,8.33$ & 1) & 0.127 & 1.213 & 1.2415 & $\therefore 1$ & 16) \\
\hline A/2W09 & 166.34 & 45,59 & 52.86 & 1) & 13.152 & 1. 2446 & 1.308 & 511 & (6) \\
\hline A72W1O & $1,9,31$ & $1,9.94$ & 48.44 & 0 & 0.051 & 0.965 & 1.003 & 16 & i) \\
\hline A72W11 & 60,43 & 60,25 & 62.5 & 0 & 0.159 & 1.12 .4 & 1.149 & 18 & 12 \\
\hline$\Lambda / 2 W 13$ & 43.86 & $1,5.26$ & 43.38 & () & 0.051 & 0.81 & 0.879 & 2.8 & 7 \\
\hline$A / 2 W 14$ & 59.19 & 68.53 & 36.84 & 0 & 0.14 & 1.232 & 1.283 & 58 & 2.9 \\
\hline A72W15 & 46.14 & 19.14 & 45.93 & 0 & 0.089 & 1.13 & 1.186 & 18 & 3 \\
\hline$A / 2 W 16$ & 54,8 & 57.81 & 52.31 & 0 & 0.102 & 0.919 & 0.958 & 15 & 8 \\
\hline A $12 W 17$ & 50.94 & 59.45 & 50.96 & () & 0.064 & 1.095 & 1.138 & 214 & 12 \\
\hline$A / 2 W 18$ & 52.18 & 66.86 & 52.02 & 0 & 0.038 & 1.138 & 1.138 & 39 & 1 \\
\hline A72W21 & 20.35 & 20.48 & 19 & 0 & 1) & 0.4014 & 0.1652 & 8 & ? \\
\hline A $12 W 22$ & 6.682 & 1.145 & 1.406 & 0 & 0 & $0.95 \%$ & $0.9 \%$ & $\therefore$ & 1 \\
\hline A72W23 & 21.77 & 22,11 & 22.23 & 1) & 0 & 0.538 & 0.572 & 10 & 3 \\
\hline A72W26 & 15.5\% & 14.19 & 15.03 & 0 & 0.013 & 0.34 & 0.406 & 1 & $?$ \\
\hline$\wedge / 2 W 2 \%$ & 18,13 & 19.6 & 17.3 & 1) & 0 & 0.498 & 0.549 & 11 & 3 \\
\hline A12W29 & 20.23 & 22.09 & 19.94 & 0 & 0 & 0.538 & $0.5 \%$ & 11 & 3 \\
\hline$\wedge 72 W 30$ & 15.84 & 15.11 & 15.29 & 0 & 0 & $0.39 / 1$ & 0.1614 & ', & ? \\
\hline N72W32 & 24.17 & 24.78 & 24.97 & () & () & 0.434 & 10.142 & 10 & 's \\
\hline A IJW13 & 0.1 .214 & 70.09 & $6,0.19$ & 0 & 0,051 & 1.121 & 1.189 & 0 & 114 \\
\hline$A / 36 / 14$ & 29.69 & 24.59 & 33.03 & 0 & 0.218 & $\therefore 355$ & 2.398 & ' & 1 \\
\hline A1315 & 49.23 & 41.6 & 144.04 & 0 & 0.013 & 0.82 .8 & 0.859 & 16 & ' \\
\hline A) $3 W 1 \%$ & 0 & 0 & 0 & 0 & 0 & 0 & 0 & 0 & 0 \\
\hline$A>3 W 18$ & 48,12 & 54.82 & 50.23 & 0) & 0.083 & 1.273 & 1.285 & 13 & 5 \\
\hline A 7321 & 52.97 & 53.16 & $56.0 ?$ & 0 & $0.1) 32$ & 0.972 & 0.997 & 12 & 7 \\
\hline A $/ 3 W 23$ & 133.73 & 50.62 & 41.69 & 0) & 0.286 & 2.007 & 2.045 & 60 & 9 \\
\hline A/3W26 & 56.14 & 55.85 & 54.27 & ) & 0.02 & 0.77 & 0.813 & 12 & 6 \\
\hline A/3W31 & 19.97 & 22.84 & 21.64 & 0 & () & 0.408 & 0.464 & 8 & 3 \\
\hline $1 / 3633$ & 26.34 & 26.68 & 26.6 & (1) & 0 & 0.464 & 0.495 & 10 & 4 \\
\hline A73W34 & 2.2 .15 & 21.2 & 22.88 & 0 & 0 & 0.414 & 0.48 & 10 & 3 \\
\hline A 73635 & 27.82 & 25.31 & 30.01 & 0 & 0 & 0.411 & 0.424 & 9 & 4 \\
\hline A 13 WI & 2.738 & 3.18 & 2.556 & 0 & 0.025 & 0.732 & 0.732 & 1 & 0 \\
\hline$\wedge / 3 W 39$ & 13.66 & 13.86 & $1 / 4.39$ & 0 & 0 & 0.362 & 10.46 .4 & 13 & 1 \\
\hline $\mathrm{A} / 3 \mathrm{~W} / \mathrm{O} O$ & 25.99 & 26.32 & 26.62 & 0 & 0 & i). 500 & 1). 546 & 10 & 4 \\
\hline A) $3 W 41$ & 31.13 & 32.23 & 29.41 & 0 & 0 & 0.432 & 0.412 & 9 & ; \\
\hline A) $3 W 45$ & 52.69 & 22.84 & 60.23 & 0 & 0.07 & 1.034 & 1.082 & 2.6 & 10 \\
\hline A73451 & 47.38 & 51.28 & 42.7 & .0 .013 & 0.343 & 2.019 & 2.057 & 41 & 16 \\
\hline
\end{tabular}

NO'TES:

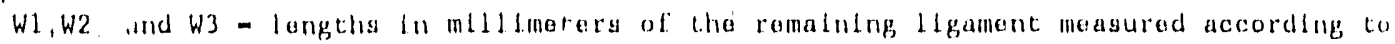
ASTM \& 1221-88.

Pl through $P$ - displacomants in inlll Lmoters masurad trom tho load vs crack mouth opentng, dlsplacoment trace, sae Flg. A.L.

$P_{\text {max }}, P_{m a n} \quad-$ maxlmum and mindmum loads roglsterod fust boloro and fusit after the rapid erack propapation avont 
Table A-5. Values measured during crack-arrest testing of the unlrradiated weldment $72 \mathrm{~W}$ and $73 \mathrm{~W}$

\begin{tabular}{|c|c|c|c|c|c|c|c|c|c|c|c|c|}
\hline spoe L Imon & 'Type & 3 & $W_{t}$ & $1+$ & 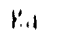 & Ro & $\Lambda$ & B & i: & D) & $\because:$ & 4.111114 \\
\hline \multirow[t]{2}{*}{$N / 2 W(0)$} & $W F_{1}$ & $\eta \dot{\prime}$ & 1,2 & .16 & 11 & 199 & 11 & 11 & $\therefore$ & s & 11 & \\
\hline & & & & & & & 19 & 13 & 18 & 2.3 & $\therefore$ & \\
\hline \multirow{2}{*}{ N/2W0\%? } & Wl: & 13 & 1,2 & 11 & 113 & joj & $\therefore 9$ & .!! & B1 & נر & $\because$ & \\
\hline & & & & & & & 19 & $\because 1$ & 11 & 2.4 & i' & \\
\hline \multirow[t]{2}{*}{ Al2WOS } & $W E$ & 25 & 1่2. & $1 / 4$ & 128 & $: 14$ & 11) & 1,3 & 2.5 & 40 & $i_{11} 1$ & i: \\
\hline & & & & & & & 19 & 40 & 32 & 23 & 28 & \\
\hline \multirow[t]{2}{*}{ N/2WO4 } & WE & 13 & 152 & . & $11 / 4$ & $: 09$ & $\therefore 8$ & 2.8 & 33 & S & 1.5 & \\
\hline & & & & & & & 19 & 21 & 11 & 23 & in & \\
\hline \multirow[t]{2}{*}{$N / 2 W 0 S$} & $W E$ & 25 & 12 & .30 & 101 & 191 & 39 & 30 & 25 & 1,4 & 1,4 & \\
\hline & & & & & & & 19 & 37 & 2.2 & 23 & $\therefore 1$ & \\
\hline \multirow[t]{2}{*}{$A / 2 W 0 \%$} & $W E$ & 33 & 152 & . & 103 & 201 & 15 & 35 & 33 & 49 & 19 & \\
\hline & & & & & & & 19 & 26 & $? \mathrm{~L}$ & 23 & 25 & \\
\hline \multirow[t]{2}{*}{ N/2WOB } & $W E$ & 25 & 152 & 31) & $101 / 4$ & 195 & 35 & 35 & 2.5 & 47 & 41 & \\
\hline & & & & & & & 19 & 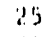 & 20 & 23 & 22 & \\
\hline \multirow[t]{2}{*}{ N/2W12 } & WE & 33 & 12\% & 1) & 111 & $\therefore 15$ & $3 / 4$ & $3 / 6$ & 33 & 50 & (1) & \\
\hline & & & & & & & 19 & 32 & $\therefore 6$ & 23 & $2 y$ & \\
\hline \multirow[t]{2}{*}{ N/2W19 } & WE & 33 & 1'? & .' & $11 / 1$ & 180 & 34 & $3 / 4$ & 31 & 1 & in & \\
\hline & & & & & & & 19 & $\because \%$ & 11 & & $\therefore 0$ & \\
\hline \multirow[t]{2}{*}{$1 / 2 W 20$} & WE: & 25 & $15 \%$ & 41 & 1,1 & $1 \% 4$ & 31) & 39 & ' & .4 & $m$ & \\
\hline & & & & & & & 19 & 10 & $"$ & 21 & 8 & \\
\hline \multirow[t]{2}{*}{ M/LWL } & $W E$ & נינ: & 16 & .311 & 11 & 16,8 & 11 & 10 & , & 32 & $3: ?$ & \\
\hline & & & & & & & 10 & 11 & ' & 2.3 & 16 & \\
\hline \multirow[t]{2}{*}{ M'W'W' } & we. & 25 & $i 6$ & 11) & .1 & 192 & 13 & 13 & $\therefore$ & 30 & $!(1)$ & $1:$ \\
\hline & & & & & & & 10) & 13 & $1 !$ & 23 & $\because 1$ & \\
\hline \multirow[t]{2}{*}{ N/2W28 } & WE: & $\therefore$ & 16 & .311 & 1,11 & 168 & 10 & 10 & $\because$ & 33 & ;1 & \\
\hline & & & & & & & 10 & 11 & i & 23 & 16 & \\
\hline \multirow[t]{2}{*}{$N / 2 W 31$} & WL: & "' & 16 & 's & 1118 & $\therefore 3 / 4$ & $1 / 4$ & 14 & נ' & 29 & ' & F. l: \\
\hline & & & & & & & 10 & $\therefore 8$ & $\therefore$ & 2.3 & 13 & \\
\hline $1 / 2 W 34$ & $W E$ & 21 & 16 & 161 & is & 168 & は & 13 & $\therefore$ & 28 & $\therefore B$ & \\
\hline & & & & & & & 10 & $1 \%$ & 10) & $\because 3$ & 16 & \\
\hline N/2W35 & W'E & .95 & 16 & $(1,1)$ & is & 132 & $1:$ & $1 \%$ & ' & 31 & 31 & \\
\hline & & & & & & & 10 & l. & , & 23 & 1 & \\
\hline N/2W36 & WE & ?' & 16 & $\therefore$ & il & $|1,1|$ & 13 & $! 3$ & $\therefore$ & (1) & $\therefore 1$ & \\
\hline & & & & & & & 10 & 11 & $" 1$ & 13 & 1' & \\
\hline N/2W3 & $W E$ & 25 & 16 & 11 & 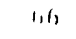 & 141 & 14 & $1 / 4$ & $: 5$ & 2.83 & $\therefore 8$ & \\
\hline & & & & & & & 10 & y & $y$ & 13 & 11 & \\
\hline$N / 2 W 38$ & W'L: & :'S & 16 & $\cdot 1, y$ & .1 & $1 / 46$ & $1 \%$ & 12 & $\therefore$ & 11 & 11 & \\
\hline & & & & & & & 10 & 1 & 1 & 13 & 11 & \\
\hline$N / 2 W 39$ & $W E$ & 2.' & 1つ2 & $\cdot(, 1)$ & i' & 161 & $1 / 1$ & $1 / 1$ & $\because$ & 64 & 1,11 & $\dot{\Lambda}$ \\
\hline & & & & & & & 19 & 4 & $\therefore$ & 23 & 11 & \\
\hline$M / 2 W 40$ & 'n'l: & 33 & 152 & 11 & 114 & .61 & $\therefore$ & 2.' & 13 & ') & 'ו & in \\
\hline & & & & & & & 19 & 32 & 16 & 33 & 'i' & \\
\hline$N / 2 W 41$ & WE: & 25 & 132 & .419 & $/ / 1$ & $1 / 19$ & $3 / 1$ & 34 & ' & ') & $\therefore(1)$ & \\
\hline & & & & & & & 19 & $1 \%$ & 10 & 23 & $1: 1$ & \\
\hline NiRW/3 & WiE & 23 & 1,2 & $\cdot 12$ & $4 \%$ & 190 & 33 & j3 & 15 & 31 & 11 & \\
\hline & & & & & & & 19 & $\because 0$ & 16 & 23 & $\therefore 1$ & \\
\hline$N / 2 W / 4$ & WE: & 23 & 152 & $(, 1)$ & $\therefore 1$ & 151 & $3 / 1$ & $3 / 1$ & $\therefore$ & ') &, 11 & \\
\hline & & & & & & & 19 & 13 & 10 & $\therefore 3$ & $1:$ & \\
\hline$N / 2 W / 4$ & WE & 33 & 152 & (') & 11 & $1 / 11$ & 18 & 38 & !) & 45 & 't & \\
\hline & & & & & & & 19 & 13 & 11 & 13 & 11 & \\
\hline $1 / 2 \mathrm{~W} / 6 \mathrm{G}$ & 'WE & 25 & 132 & $\ldots 1$ & $\because !$ & 134 & $i 6$ & $\therefore 6$ & 15 & 38 & 13 & \\
\hline & & & & & & & 19 & $1 !$ & 13 & i) & 11 & \\
\hline$N / 2 W_{4} /$ & 'WE & 33 & 152 & $\cdot 11)$ & 11 & 186 & 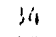 & $3 / 1$ & 13 & ') & 311 & \\
\hline & & & & & & & 19 & $\because 0$ & 16 & 13 & il & \\
\hline $1 / 2 W / 48$ & $W E$ & 2.5 & 122 & 30 & $1 H$ & 194 & $1 / 4$ & 3 & 15 & $(19$ & 11 & \\
\hline & & & & & & & 19 & 22 & 18 & 23 & $\because a$ & \\
\hline
\end{tabular}


Table A-5. (continued)

\begin{tabular}{|c|c|c|c|c|c|c|c|c|c|c|c|c|}
\hline Specimen & Type & B & $w_{1}$ & $\mathrm{~T}$ & $k a$ & ko & $\wedge$ & H & :: & D & : & Whl iditi \\
\hline$A / 2 W 57$ & $\mathrm{DX}$ & 33 & 152 & 21 & $1 / 46$ & 216 & $\begin{array}{l}55 \\
19\end{array}$ & $\begin{array}{l}5,5 \\
5,6\end{array}$ & $\begin{array}{l}33 \\
1.3\end{array}$ & $\begin{array}{l}13 \\
2.5\end{array}$ & 13 & $(\because, 1)$ \\
\hline N/2W6? & $\mathrm{DX}$ & 33 & 1,2 & 10 & 136 & 267 & $\begin{array}{l}37 \\
19\end{array}$ & $\begin{array}{l}37 \\
1.6\end{array}$ & $\begin{array}{l}33 \\
37\end{array}$ & $\begin{array}{l}31 \\
25\end{array}$ & $\because 1$ & 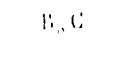 \\
\hline$A / 2 W 63$ & DX & 33 & 152 & .1 & 125 & 232 & $\begin{array}{l}140 \\
19\end{array}$ & $\begin{array}{l}40 \\
39\end{array}$ & $\begin{array}{l}33 \\
11\end{array}$ & $\begin{array}{l}28 \\
25\end{array}$ & 28 & \\
\hline A72W64 & DX & 33 & 152 & 1 & 108 & 2.17 & $\begin{array}{l}38 \\
1.9\end{array}$ & $\begin{array}{l}38 \\
29\end{array}$ & $\begin{array}{l}13 \\
23\end{array}$ & $\begin{array}{l}31 \\
25\end{array}$ & 31 & \\
\hline A $72 W 65$ & DX & 33 & 152 & 4 & 125 & 256 & $\begin{array}{l}36 \\
19\end{array}$ & $\begin{array}{l}36 \\
39\end{array}$ & $\begin{array}{l}33 \\
31\end{array}$ & $\begin{array}{l}33 \\
25\end{array}$ & 33 & \\
\hline$\wedge / 2 W 66$ & DX & 33 & 152 & -2 & 103 & 229 & $\begin{array}{l}31 \\
19\end{array}$ & $\begin{array}{l}31 \\
26\end{array}$ & $\begin{array}{l}33 \\
2.1\end{array}$ & $\begin{array}{l}37 \\
25\end{array}$ & 37 & \\
\hline$A 72 W 68$ & DX & 33 & 152 & 5 & 115 & 229 & $\begin{array}{l}36 \\
19\end{array}$ & $\begin{array}{l}36 \\
33\end{array}$ & $\begin{array}{l}33 \\
27\end{array}$ & $\begin{array}{l}32 \\
25\end{array}$ & 32 & \\
\hline Aา2W71 & $\mathrm{DX}$ & 33 & 152 & .14 & 31 & 237 & $\begin{array}{l}24 \\
19\end{array}$ & $\begin{array}{l}24 \\
20\end{array}$ & $\begin{array}{l}33 \\
16\end{array}$ & $\begin{array}{l}45 \\
25\end{array}$ & 45 & \\
\hline$A / 2673$ & $D X$ & 33 & 152 & 5 & $1 / 12$ & 230 & $\begin{array}{l}148 \\
19\end{array}$ & $\begin{array}{l}1,8 \\
50\end{array}$ & $\begin{array}{l}33 \\
1,6\end{array}$ & $\begin{array}{l}21 \\
25\end{array}$ & 21 & $\because . \mathrm{D}$ \\
\hline $172 W 83$ & WE & 3 & 2013 & .30 & 85 & $1 / 16$ & $\begin{array}{l}2,9 \\
25\end{array}$ & $\begin{array}{l}1,9 \\
17\end{array}$ & $\begin{array}{l}31 \\
14\end{array}$ & $\begin{array}{l}50 \\
23\end{array}$ & $\begin{array}{l}30 \\
12\end{array}$ & \\
\hline A12W84 & WE & 51 & $: 03$ & 0 & 107 & 178 & $\begin{array}{l}57 \\
25\end{array}$ & $\begin{array}{l}17 \\
28\end{array}$ & $\begin{array}{l}31 \\
23\end{array}$ & $\begin{array}{l}32 \\
23\end{array}$ & $\begin{array}{l}52 \\
20\end{array}$ & \\
\hline A $/ 2 W 85$ & WE & 'l & $? 03$ & .15 & 95 & 195 & $\begin{array}{l}34 \\
25\end{array}$ & $\begin{array}{l}3 / 4 \\
22\end{array}$ & $\begin{array}{l}11 \\
11\end{array}$ & $\begin{array}{l}29 \\
24\end{array}$ & $\begin{array}{l}19 \\
13\end{array}$ & \\
\hline A) 3W01 & WE & 23 & 16 & .145 & 32. & 151 & $\begin{array}{l}10 \\
10\end{array}$ & $\begin{array}{l}10 \\
r_{1}\end{array}$ & 26 & $\begin{array}{l}33 \\
23\end{array}$ & $\begin{array}{l}13 \\
13\end{array}$ & \\
\hline A/3W02 & WE & 25 & 16 & .45 & 15 & 172 & $\begin{array}{l}1 / 4 \\
10\end{array}$ & $\begin{array}{l}14 \\
13\end{array}$ & $\begin{array}{l}16 \\
10\end{array}$ & $\begin{array}{l}29 \\
23\end{array}$ & $\begin{array}{l}.9 \\
16\end{array}$ & \\
\hline$\therefore / 3603$ & $W E$ & 25 & 16 & .45 & 6,14 & 203 & $\begin{array}{r}8 \\
10\end{array}$ & $\begin{array}{l}8 \\
19\end{array}$ & 26 & $\begin{array}{l}35 \\
23\end{array}$ & $\begin{array}{l}15 \\
23\end{array}$ & $\therefore . H$ \\
\hline $173 W_{04}$ & WE & $2 i$ & 16 & .30 & 67 & 181 & $\begin{array}{l}10 \\
10\end{array}$ & $\begin{array}{l}10 \\
11\end{array}$ & $\begin{array}{l}26 \\
8\end{array}$ & $\begin{array}{l}32 . \\
23\end{array}$ & $\begin{array}{l}32 \\
19\end{array}$ & \\
\hline A73WOS & WE & 25 & 16 & .30 & 10 & $? n_{4}^{\prime}$ & $\begin{array}{r}8 \\
10\end{array}$ & $\begin{array}{r}8 \\
12\end{array}$ & 16 & $\begin{array}{l}35 \\
23\end{array}$ & $\begin{array}{l}3 \\
3\end{array}$ & $\therefore . M$ \\
\hline$A / 3 W 06$ & WE & 25 & 16 & .35 & 83 & $18 / 4$ & $\begin{array}{l}13 \\
10\end{array}$ & $\begin{array}{l}13 \\
16\end{array}$ & $\begin{array}{l}26 \\
13\end{array}$ & $\begin{array}{l}30 \\
23\end{array}$ & $\begin{array}{l}10 \\
19\end{array}$ & B \\
\hline A $/ 3 W 07$ & DX & 13 & 1,2 & 5 & 129 & 277 & $\begin{array}{l}32 \\
19\end{array}$ & $\begin{array}{l}32 \\
1.2\end{array}$ & $\begin{array}{l}33 \\
34\end{array}$ & $\begin{array}{l}36 \\
25\end{array}$ & 36 & is \\
\hline$A 73608$ & $D X$ & 33 & 152 & 5 & 119 & 222 & $\begin{array}{l}160 \\
19\end{array}$ & $\begin{array}{l}1.0 \\
16\end{array}$ & $\begin{array}{l}33 \\
.99\end{array}$ & $\begin{array}{l}28 \\
25\end{array}$ & 28 & \\
\hline N/3609 & $\mathrm{DX}$ & 33 & 152 & ') & $11 ?$ & 2.16 & $\begin{array}{l}38 \\
19\end{array}$ & $\begin{array}{l}38 \\
32 .\end{array}$ & $\begin{array}{l}13 \\
2.5\end{array}$ & $\begin{array}{l}30 \\
25\end{array}$ & 30 & \\
\hline$\therefore 73 w 10$ & $w_{i}$ & 33 & 152 & .16 & 17 & 216 & $\begin{array}{l}17 \\
19\end{array}$ & $\begin{array}{l}17 \\
15\end{array}$ & $\begin{array}{l}13 \\
12\end{array}$ & $\begin{array}{l}61 \\
23\end{array}$ & $\begin{array}{l}51 \\
28\end{array}$ & $\therefore$ \\
\hline$A / 3 W 11$ & WE & 25 & 152 & .32 & 85 & 159 & $\begin{array}{l}35 \\
19\end{array}$ & $\begin{array}{l}35 \\
17\end{array}$ & $\begin{array}{l}25 \\
1 / 4\end{array}$ & $\begin{array}{l}43 \\
23\end{array}$ & $\begin{array}{l}143 \\
13\end{array}$ & \\
\hline $1 / 3 W 16$ & WE & 25 & 152 & .29 & 89 & 172 & $\begin{array}{l}33 \\
19\end{array}$ & $\begin{array}{l}33 \\
19\end{array}$ & $\begin{array}{l}25 \\
15\end{array}$ & $\begin{array}{l}1.5 \\
23\end{array}$ & $\begin{array}{l}\therefore 5 \\
17\end{array}$ & \\
\hline$\therefore / 3 W 20$ & WE & 25 & 152 & .16 & 126 & 203 & $\begin{array}{l}140 \\
19\end{array}$ & $\begin{array}{l}10 \\
33\end{array}$ & $\begin{array}{l}25 \\
31\end{array}$ & $\begin{array}{l}38 \\
23\end{array}$ & $\begin{array}{l}38 \\
25\end{array}$ & (: \\
\hline A/3W22 & $W E$ & 33 & 152 & 16 & 110 & 232 & $\begin{array}{l}28 \\
19\end{array}$ & $\begin{array}{l}28 \\
10\end{array}$ & $\begin{array}{l}13 \\
\therefore 6\end{array}$ & $\begin{array}{l}10 \\
\therefore 3\end{array}$ & $\begin{array}{l}30 \\
33\end{array}$ & \\
\hline Nisw24 & WE. & 33 & 152 & .13 & 89 & 273 & $\begin{array}{l}1 / 4 \\
19\end{array}$ & $\begin{array}{l}1 / 4 \\
20\end{array}$ & $\begin{array}{l}33 \\
16\end{array}$ & $\begin{array}{l}6,4 \\
23\end{array}$ & $\begin{array}{l}6,4 \\
146\end{array}$ & $A, B$ \\
\hline A 73 W25 & WE & 25 & 152 & 15 & $1 / 41$ & $: 143$ & $\begin{array}{l}37 \\
19\end{array}$ & $\begin{array}{l}37 \\
19\end{array}$ & $\begin{array}{l}25 \\
39\end{array}$ & $\begin{array}{l}41 \\
23\end{array}$ & $\begin{array}{l}11 \\
36\end{array}$ & 1:. C: \\
\hline
\end{tabular}


Table A-5. (continued)

\begin{tabular}{|c|c|c|c|c|c|c|c|c|c|c|c|c|}
\hline Specimen & Type & $B$ & $w_{t}$ & $\mathrm{l}$ & ra & ko & $\wedge$ & r & 1: & D & l: & ¿allulle \\
\hline \multirow[t]{2}{*}{ A 73 W27 } & WE & 33 & 152 & $\cdot 12$ & 111 & $\therefore 02$ & 36 & 36 & 33 & 42 & 42 & \\
\hline & & & & & & & 19 & 30 & $x^{1 / 4}$ & 23 & 25 & \\
\hline \multirow{2}{*}{ A 73 W2 8} & WE & 25 & 132 & 61 & 1,9 & 146 & 10 & $: 0$ & (5) & 1.8 & 48 & \\
\hline & & & & & & & 19 & (1) & $y$ & 23 & 11 & \\
\hline \multirow[t]{2}{*}{ A 73 W29 } & WE & 33 & 152 & 30 & 100 & 205 & 31 & 31 & 33 & 47 & 41 & \\
\hline & & & & & & & 19 & $2 / 4$ & 19 & 23 & 25 & \\
\hline \multirow[t]{2}{*}{ A73W30 } & WE & 25 & 152 & .44 & 11 & 161 & 26 & 26 & 25 & 52 & 32 & \\
\hline & & & & & & & 19 & 12 & 9 & 23 & $1 / 4$ & \\
\hline \multirow[t]{2}{*}{ A73W32 } & WE & 25 & 76 & $-1,9$ & 26 & 192 & 1 & 1 & 25 & 36 & 36 & $\therefore$ \\
\hline & & & & & & & 10 & 1 & 5 & 23 & 20 & \\
\hline \multirow[t]{2}{*}{ A73w36 } & WE & 25 & 76 & .59 & 12 & 168 & 14 & $1 / 4$ & 25 & 29 & 29 & \\
\hline & & & & & & & 10 & 11 & 9 & 23 & 15 & \\
\hline \multirow[t]{2}{*}{ A73W38 } & $W E$ & 25 & 16 & .62 & bo & 160 & 1 & 1 & 25 & 36 & 36 & $\wedge$ \\
\hline & & & & & & & 10 & 5 & 4 & 23 & 13 & \\
\hline \multirow[t]{2}{*}{ A73W4 2} & WE & 25 & 16 & .60 & ' 8 & 166 & 3 & 9 & 25 & 34 & 34 & \\
\hline & & & & & & & 10 & 1 & 6 & 23 & $1 / 4$ & \\
\hline \multirow[t]{2}{*}{ A73W4 3.} & $W E$ & 25 & 152 & . 15 & 13 & $1 / 42$ & 36 & 36 & 25 & 1.7 & 47 & \\
\hline & & & & & & & 19 & 12 & 10 & 23 & 11 & \\
\hline \multirow[t]{2}{*}{ A73W44 } & $W E$ & 33 & 152 & $\therefore 13$ & 123 & $\therefore 04$ & is & 43 & 33 & 39 & 39 & \\
\hline & & & & & & & 19 & 37 & 30 & 23 & 25 & \\
\hline \multirow[t]{2}{*}{ A73W4 6} & $W E$ & 33 & 152 & .15 & 124 & 219 & 11 & 11 & 33 & 43 & 43 & \\
\hline & & & & & & & 19 & 38 & 30 & 23 & 29 & \\
\hline \multirow[t]{2}{*}{ A73647 } & WE & 25 & 152 & -145 & 85 & 156 & $1,0)$ & 1,0 & .25 & 143 & 43 & \\
\hline & & & & & & & 19 & 11 & 13 & 23 & $1 / 4$ & \\
\hline \multirow[t]{2}{*}{ A73W4 8} & WE & 25 & 152 & .31 & 15 & $1 / 0$ & $: 8$ & $\therefore 8$ & 23 & 55 & b' & \\
\hline & & & & & & & 19 & 13 & 11 & 23 & 17 & \\
\hline \multirow[t]{2}{*}{ A73W49 } & $W E$ & 33 & 1 '2 & .15 & 117 & 222 & 16 & 36 & 33 & 1.8 & 148 & \\
\hline & & & & & & & 19 & 33 & 27 & 23 & 30 & \\
\hline \multirow[t]{2}{*}{ A73W50 } & WE & 25 & 152 & $\cdot 30$ & 80 & 221 & $? 0$ & 20 & 25 & $6 \%$ & 6,4 & \\
\hline & & & & & & & 19 & 13 & 12 & 23 & 29 & \\
\hline \multirow[t]{2}{*}{ A73W5 2} & $W E$ & 25 & 1,2 & $\cdot .79$ & 11 & 219 & 18 & 18 & is & 63 & 65) & \\
\hline & & & & & & & 19 & $1 / 4$ & 11 & 23 & 28 & \\
\hline \multirow[t]{2}{*}{ A/3W75 } & $D X$ & $\therefore 1$ & $: 03$ & ') & 107 & .29 & 41 & $i t$ & (נ, & 14 & $\because 1$ & \\
\hline & & & & & & & &.$i$ & $\therefore$ & $\therefore ?$ & $!^{\prime}$ & \\
\hline \multirow[t]{2}{*}{ A73W8 5} & $D X$ & 33 & $1 s 2$ & ') & 137 & 214 & 50 & ') & 3 & 18 & 18 & $\therefore, D$ \\
\hline & & & & & & & & 19 & 41 & 38 & は & \\
\hline \multirow[t]{2}{*}{ A73W86 } & $D X$ & 33 & 152 & - 'j & 101 & 209 & $3 / 4$ & $3 / 4$ & 33 & 34 & $3 / 4$ & \\
\hline & & & & & & & & 19 & is & 20 & נ' & \\
\hline \multirow[t]{2}{*}{ A $73 W 87$} & DX & 33 & 132 & ') & 113 & 247 & 31 & 31 & 33 & 36 & 36 & \\
\hline & & & & & & & & 19 & 32 & 26 & 25 & \\
\hline \multirow[t]{2}{*}{ A $73 W 88$} & DX & 33 & 152 & 15 & 132 & 228 & 144 & 1,4 & 33 & 25 & $2 b$ & \\
\hline & & & & & & & & 19 & 1.4 & 36 & 25 & \\
\hline
\end{tabular}

NOTES:

Type: " either WE (weld-embrittled) or DX (duplex)

$B, W_{t}$ nominal overall specimen size, ill millimeters, see fig, 2

$T$ - test temperature in ${ }^{\circ} \mathrm{C}$

$K_{0}, K_{0}$ - stress intensicy factor at crack arrest and at crack Initiation, respectively, in MPa.Jin

The letters A, B, ... E are the letters used in the Asim E $1221-88$ validity criterla. The top row of numbers are the measured values for each criterion, and those below are the minimuns specified in the standard. The retnaining, lipament has to tulfill two criteria, and thus the same value is repeated for $A$ and $B$. The same is true tor the cract. jump.

$A, B$ - Length of remaining 11 gament, millineters.

(; - sperimen width, inillimeters.

D.E - crack jump, inillimeters. For duplex specimens, only D is applicable.

Validity : On or more letters in this column indicates that the specimen did not meet the

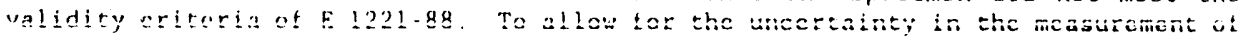
the crack front, the incasured values were increased by 10 before comparing thein with the criteria in the standard 
Table A-6. Velues measured during crack-arrest testing of irradiated weldment $72 \mathrm{~W}$ and $73 \mathrm{~W}$

\begin{tabular}{|c|c|c|c|c|c|c|c|c|c|c|c|c|}
\hline Specimen & Type & B & $w_{t}$ & $T$ & $k_{0}$ & $k_{0}$ & A & B & C & D & $E$ & I1dity \\
\hline A72W06 & WE & 25 & 152 & 90 & 160 & 182 & $\begin{array}{l}67 \\
19\end{array}$ & $\begin{array}{l}67 \\
50\end{array}$ & $\begin{array}{l}25 \\
40\end{array}$ & $\begin{array}{l}15 \\
23\end{array}$ & $\begin{array}{l}15 \\
15\end{array}$ & $C, D$ \\
\hline A72W09 & WE & 33 & 152 & 90 & 120 & 176 & $\begin{array}{l}48 \\
19\end{array}$ & $\begin{array}{l}48 \\
28\end{array}$ & $\begin{array}{l}33 \\
23\end{array}$ & $\begin{array}{l}34 \\
23\end{array}$ & $\begin{array}{l}34 \\
14\end{array}$ & \\
\hline A72W10 & WE & 25 & 152 & 75 & 101 & 155 & $\begin{array}{l}49 \\
19\end{array}$ & $\begin{array}{l}49 \\
20\end{array}$ & $\begin{array}{l}25 \\
16\end{array}$ & $\begin{array}{l}34 \\
23\end{array}$ & 11 & \\
\hline A72W11 & WE & 25 & 152 & 75 & 133 & 163 & $\begin{array}{l}61 \\
19\end{array}$ & $\begin{array}{l}61 \\
35\end{array}$ & $\begin{array}{l}25 \\
28\end{array}$ & $\begin{array}{l}22 \\
23\end{array}$ & 22 & \\
\hline A $72 W 13$ & WE & 25 & 152 & 60 & 81 & 130 & $\begin{array}{l}19 \\
44\end{array}$ & $\begin{array}{l}35 \\
44\end{array}$ & $\begin{array}{l}20 \\
25\end{array}$ & $\begin{array}{l}23 \\
38\end{array}$ & $\begin{array}{l}12 \\
38\end{array}$ & \\
\hline A72W14 & WE & 33 & 152 & 100 & 144 & 177 & $\begin{array}{l}19 \\
62\end{array}$ & $\begin{array}{l}13 \\
62\end{array}$ & $\begin{array}{l}10 \\
33\end{array}$ & $\begin{array}{l}23 \\
22\end{array}$ & $\begin{array}{l}7.3 \\
22 .\end{array}$ & \\
\hline A72W15 & WE & 25 & 152 & 75 & 114 & 177 & $\begin{array}{l}19 \\
47\end{array}$ & $\begin{array}{l}41 \\
47\end{array}$ & $\begin{array}{l}33 \\
25\end{array}$ & $\begin{array}{l}23 \\
36\end{array}$ & $\begin{array}{l}14 \\
36\end{array}$ & \\
\hline A72W16 & WE & 25 & 152 & 76 & & & 19 & 25 & $\begin{array}{l}20 \\
25\end{array}$ & $\begin{array}{l}23 \\
28\end{array}$ & $\begin{array}{l}36 \\
14\end{array}$ & \\
\hline A $72 W 17$ & WE & 33 & 152 & 10 & 102 & 138 & $\begin{array}{l}55 \\
19\end{array}$ & $\begin{array}{l}35 \\
20\end{array}$ & $\begin{array}{l}23 \\
16\end{array}$ & $\begin{array}{l}28 \\
23\end{array}$ & $\begin{array}{l}28 \\
8.5\end{array}$ & \\
\hline A72W18 & WE & 25 & 152 & 100 & 118 & 168 & $\begin{array}{l}54 \\
19\end{array}$ & $\begin{array}{l}54 \\
28\end{array}$ & $\begin{array}{l}33 \\
22\end{array}$ & $\begin{array}{l}29 \\
22\end{array}$ & $\begin{array}{l}29 \\
13\end{array}$ & \\
\hline A72W21 & WE & 25 & 152 & 90 & 132 & 185 & $\begin{array}{l}57 \\
19\end{array}$ & $\begin{array}{l}57 \\
34\end{array}$ & $\begin{array}{l}25 \\
27\end{array}$ & $\begin{array}{l}26 \\
23\end{array}$ & $\begin{array}{l}26 \\
16\end{array}$ & \\
\hline A72W22 & WE & 25 & 76 & 30 & 53 & 99 & $\begin{array}{l}20 \\
9.6\end{array}$ & $\begin{array}{l}20 \\
5.2\end{array}$ & $\begin{array}{l}25 \\
4.2\end{array}$ & $\begin{array}{l}23 \\
23\end{array}$ & $\begin{array}{l}23 \\
4\end{array}$ & \\
\hline A72W26 & WE & 25 & 76 & 60 & 74 & 129 & $\begin{array}{l}22 \\
9.5\end{array}$ & $\begin{array}{l}22 \\
10\end{array}$ & $\begin{array}{l}25 \\
8.3\end{array}$ & $\begin{array}{l}21 \\
23\end{array}$ & $\begin{array}{l}21 \\
7.3\end{array}$ & $D$ \\
\hline A72W27 & WE & 25 & 76 & -25 & 38 & 81 & $\begin{array}{l}15 \\
9.5 \\
18\end{array}$ & $\begin{array}{l}15 \\
2.5 \\
1.8\end{array}$ & $\begin{array}{l}25 \\
2 \\
25\end{array}$ & $\begin{array}{l}28 \\
? 3\end{array}$ & $\begin{array}{l}28 \\
2.4\end{array}$ & \\
\hline A72W29 & WE & 25 & 76 & 29 & 61 & 121 & $\begin{array}{l}18 \\
9.5 \\
21\end{array}$ & $\begin{array}{r}7 \\
21\end{array}$ & $\begin{array}{l}25 \\
5.6 \\
25\end{array}$ & $\begin{array}{l}25 \\
23\end{array}$ & $\begin{array}{l}25 \\
6.1\end{array}$ & \\
\hline A73W13 & WE & 25 & 152 & 75 & 150 & 168 & $\begin{array}{l}9.6 \\
66\end{array}$ & & $\begin{array}{l}6.5 \\
25\end{array}$ & $\begin{array}{l}23 \\
12\end{array}$ & $\begin{array}{l}18 \\
4.6 \\
12\end{array}$ & $D$ \\
\hline A73W1.4 & WE & 33 & 152 & 90 & 159 & 325 & 29 & $\begin{array}{l}19 \\
29\end{array}$ & $\begin{array}{l}41 \\
33\end{array}$ & $\begin{array}{l}33 \\
48\end{array}$ & $\begin{array}{l}12 \\
23 \\
48\end{array}$ & $\begin{array}{l}C, D \\
12\end{array}$ \\
\hline A73W15 & WE & 25 & 152 & 60 & & & 46 & $\begin{array}{l}19 \\
46\end{array}$ & $\begin{array}{l}46 \\
25\end{array}$ & 37 & $\begin{array}{l}48 \\
23\end{array}$ & $\begin{array}{l}B, C \\
44\end{array}$ \\
\hline A73W17 & WE & 33 & 152 & 230 & 01 & 120 & 46 & $\begin{array}{l}46 \\
19\end{array}$ & $\begin{array}{l}25 \\
12\end{array}$ & $\begin{array}{l}32 \\
9.4\end{array}$ & $\begin{array}{l}32 \\
23\end{array}$ & 6.3 \\
\hline A73W18 & WE & 25 & 152 & 75 & 131 & & & & & & & \\
\hline A73W21 & WE & 25 & 152 & 75 & 107 & 144 & 54 & $\begin{array}{c}51 \\
19 \\
54\end{array}$ & $\begin{array}{c}25 \\
31 \\
25\end{array}$ & $\begin{array}{l}26 \\
25\end{array}$ & $\begin{array}{l}26 \\
23\end{array}$ & 14 \\
\hline A73W23 & WE & 25 & 152 & 90 & 180 & & 45 & $\begin{array}{l}54 \\
19 \\
45\end{array}$ & $\begin{array}{l}21 \\
25\end{array}$ & $\begin{array}{l}24 \\
17\end{array}$ & $\begin{array}{l}24 \\
23\end{array}$ & 8.4 \\
\hline A73W26 & WE & 25 & 152 & 75 & 88 & 115 & 45 & $\begin{array}{l}45 \\
19 \\
55\end{array}$ & $\begin{array}{l}60 \\
25\end{array}$ & $\begin{array}{l}32 \\
48 \\
22\end{array}$ & $\begin{array}{l}32 \\
23\end{array}$ & $\begin{array}{l}\text { B, C } \\
29\end{array}$ \\
\hline A73W31 & WE & 25 & 76 & 29 & 57 & 98 & & $\begin{array}{l}19 \\
22\end{array}$ & $\begin{array}{l}1.4 \\
25\end{array}$ & $\begin{array}{l}11 \\
21\end{array}$ & $\begin{array}{l}22 \\
2.3 \\
21\end{array}$ & 5.4 \\
\hline A73W33 & $W E$ & 25 & 76 & 60 & & 110 & 27 & $\begin{array}{l}9.5 \\
27\end{array}$ & $\begin{array}{l}5.7 \\
25\end{array}$ & $\begin{array}{l}4.6 \\
16\end{array}$ & $\begin{array}{l}21 \\
23 \\
16\end{array}$ & $\begin{array}{l}\text { D } \\
3.7\end{array}$ \\
\hline A73W34 & WE & 25 & 76 & 29 & 60 & 100 & 22 & $\begin{array}{l}9.5 \\
22\end{array}$ & $\begin{array}{l}9.7 \\
25\end{array}$ & $\begin{array}{l}7.8 \\
21\end{array}$ & $\begin{array}{l}23 \\
21\end{array}$ & $\begin{array}{l}D \\
\dot{4} .8\end{array}$ \\
\hline & & & & & & & & 9.5 & 6.2 & 5 & $\begin{array}{l}21 \\
23\end{array}$ & $\begin{array}{l}\text { D } \\
3.8\end{array}$ \\
\hline
\end{tabular}


iable A.6 (continued)

\begin{tabular}{|c|c|c|c|c|c|c|c|c|c|c|c|c|}
\hline Specimen & Type & B & $w_{t}$ & $\mathrm{~T}$ & $K_{a}$ & $k_{0}$ & A & B & C & D & E & Validity \\
\hline A.73W35 & WE & 25 & 76 & 29 & 67 & 99 & 28 & $\begin{array}{l}28 \\
9.5\end{array}$ & $\begin{array}{l}25 \\
7.8\end{array}$ & $\begin{array}{l}15 \\
6.2\end{array}$ & $\begin{array}{l}15 \\
2.3\end{array}$ & $\begin{array}{l}D \\
3.7\end{array}$ \\
\hline A73W37 & WE & 25 & 76 & -25 & 29 & 171 & 2.8 & $\begin{array}{l}2.8 \\
9.5\end{array}$ & $\begin{array}{l}25 \\
1.4\end{array}$ & $\begin{array}{l}40 \\
1.1\end{array}$ & $\begin{array}{l}40 \\
23\end{array}$ & $\begin{array}{l}\text { A } \\
10\end{array}$ \\
\hline A73W39 & WE & 25 & 76 & .25 & 41 & 88 & 14 & $\begin{array}{l}14 \\
9.5\end{array}$ & $\begin{array}{l}25 \\
2.7\end{array}$ & $\begin{array}{l}29 \\
2.2\end{array}$ & $\begin{array}{l}29 \\
23\end{array}$ & 2.7 \\
\hline A73W40 & WE & 25 & 76 & 60 & 81 & 121 & 26 & $\begin{array}{l}26 \\
9.5\end{array}$ & $\begin{array}{l}2.5 \\
12\end{array}$ & $\begin{array}{l}16 \\
9.3\end{array}$ & $\begin{array}{l}16 \\
23\end{array}$ & $\begin{array}{l}D \\
5.8\end{array}$ \\
\hline A73W41 & WE & 25 & 76 & 60 & 79 & 103 & 31 & $\begin{array}{l}31 \\
9.5\end{array}$ & $\begin{array}{l}25 \\
11\end{array}$ & $\begin{array}{c}12 \\
9\end{array}$ & $\begin{array}{l}12 \\
23\end{array}$ & $\begin{array}{l}\mathrm{D} \\
4.2\end{array}$ \\
\hline A73W45 & WE & 25 & 152 & 90 & 114 & 158 & 55 & $\begin{array}{l}55 \\
19\end{array}$ & $\begin{array}{l}25 \\
24\end{array}$ & $\begin{array}{l}28 \\
19\end{array}$ & $\begin{array}{l}28 \\
23\end{array}$ & 10 \\
\hline A73W51 & WE & 33 & 152 & 100 & 184 & 274 & 47 & $\begin{array}{l}47 \\
19\end{array}$ & $\begin{array}{l}33 \\
63\end{array}$ & $\begin{array}{l}36 \\
50\end{array}$ & $\begin{array}{l}36 \\
23\end{array}$ & $\begin{array}{l}\text { B, C } \\
31\end{array}$ \\
\hline
\end{tabular}

NOTES :
Type: = either WE (weld-embrittled) or DX (duplex)
$B, W_{t}$ - nominal overall. specimen size, in millimeters, see Fig. 2
$T$ - test temperalise in ${ }^{\circ} \mathrm{C}$
$K_{a}, K_{0}$ - stress intenst ty tactor ar crack arrcst end at crack inftiation, respectively, in $M P_{a} \cdot i \cdot s$.

The letters A, B, ... E are the letters used in the ASTM E 1221-88 validity cititeria. The top row of numbers are the measured values for each criterion, and those below are the minimums specifled in the standard. The remaining ligament has to fulfill two criterla, and thus the same value is repeated for $A$ and $B$. The same is true for the crack jump.

$A, B$ - length of remaining ligament, millimeters.

C specimen width, millimeters.

$D, E=$ crack jump, millimeters. For duplex specimens, only $D$ is applicable.

Validity - On or more letters in this column indicates that the specimen did not meet the validity criteria of E 1221-8. To allow for the uncertainty in the measurement of the crack front, hte measured values were increased by 108 before comparing them with the criteria in the standard. 
Crack arrest hata sheet

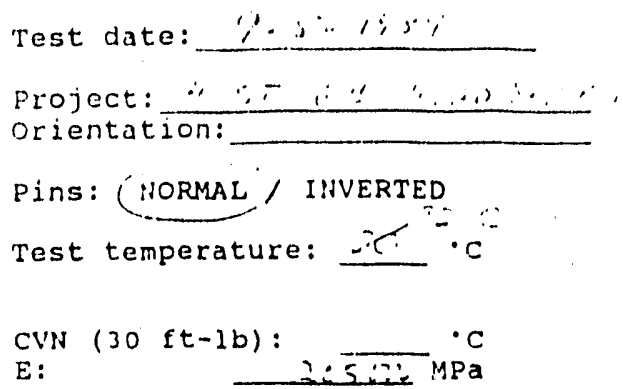

(1) Average of 2 measurements (2) Diameter of starter hole POST-TEST

Crack face:

Measure (W-Aa) at 3 poipts: at $+B N / 4$ at midline at $-B N / 4$

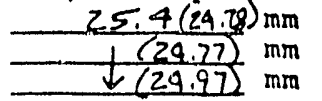

Load/COD chart:

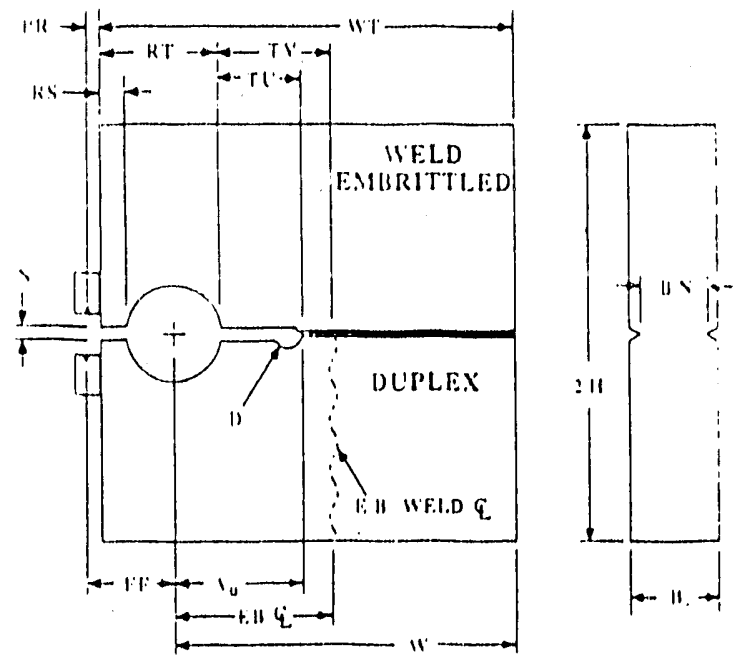

$\mathrm{R}_{1}=\frac{a}{a}$ mils
$\mathrm{R}_{3}=\frac{a}{17.0}$ mils 17.1
$\mathrm{P}_{1}=\frac{18.5}{\mathrm{mils}} 18.6$

$P_{\text {max }} 2220$ ib

$P_{\min } \frac{222 a}{104 a} 1 b$

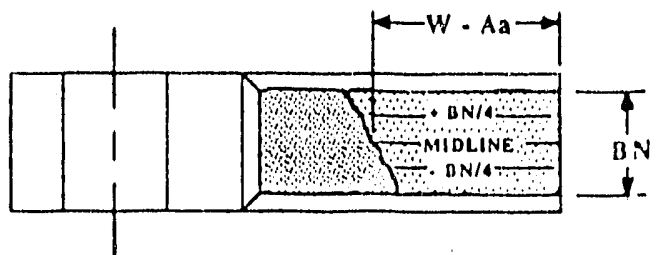

Fig. A-1. Comparison of values of Young's modull as calculated from an American Soclety of Mechanical Engineers table and an Electric Power Research Institute expression. 
APPENDIX B

IISTING OF BASIC COMPUTER CODE CA_TEST 
Documentation of Computer Code CA TEST

The listing of the computer code CA_TEST has been included solely for purposes of QA. It details in a concise manner the computational details that were performed with the crack arrest data. Moreover, the methodology in crack-arrest testing is still evolving. The standard test method used in this work, ASTM Test for Determining Plane-Strain CrackArrest Fracture Toughness, $K_{I a}$, of Ferritic Steels (E 1221-88), is in its first issue and will probably be modified. It is therefore important that the precise details of the algorithms used to calculate $k_{a}$ as well as the validity criteria be documented. If crack-arrest methodology does change, that data can be re-evaluated using the new methodology. 


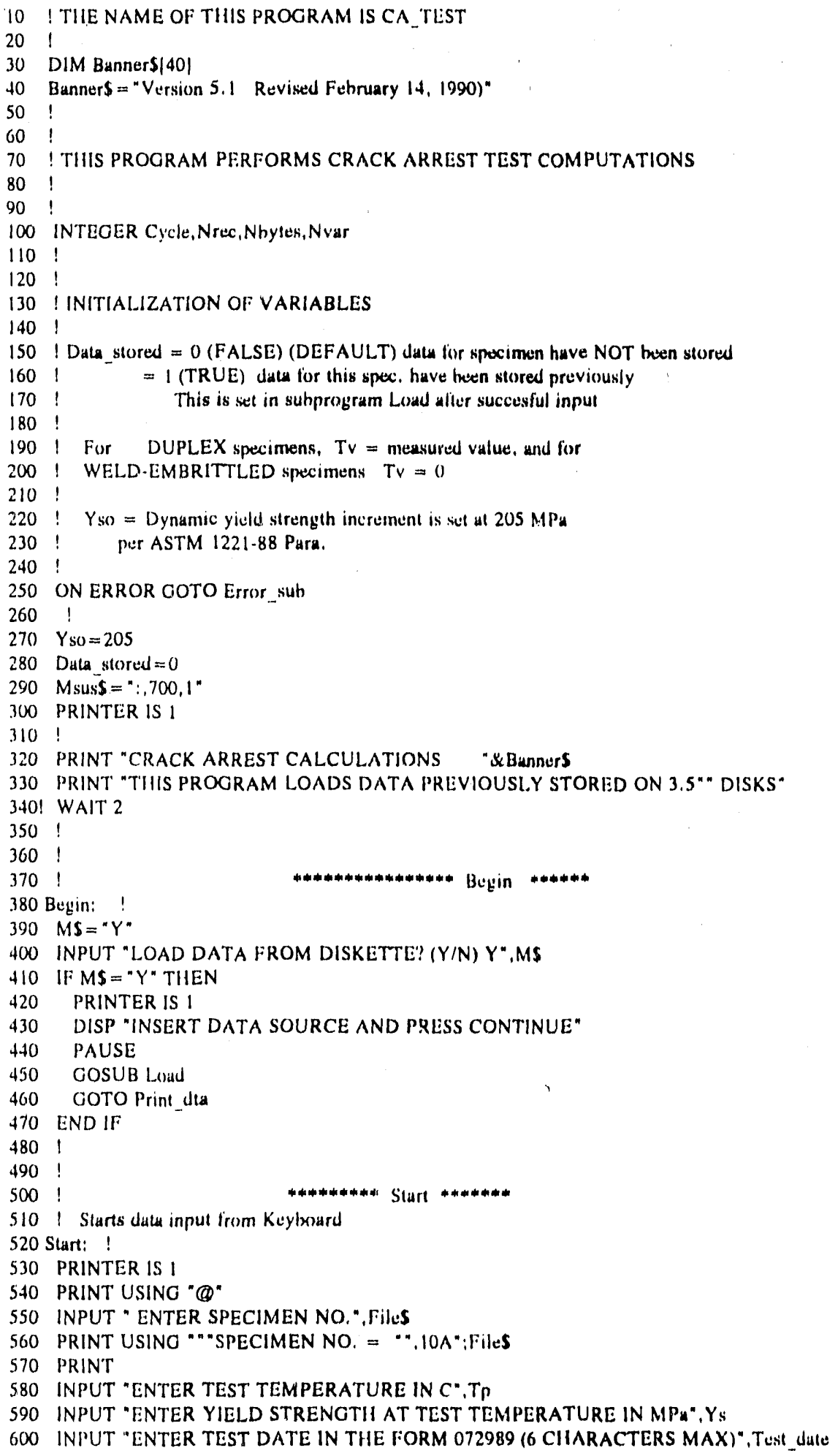




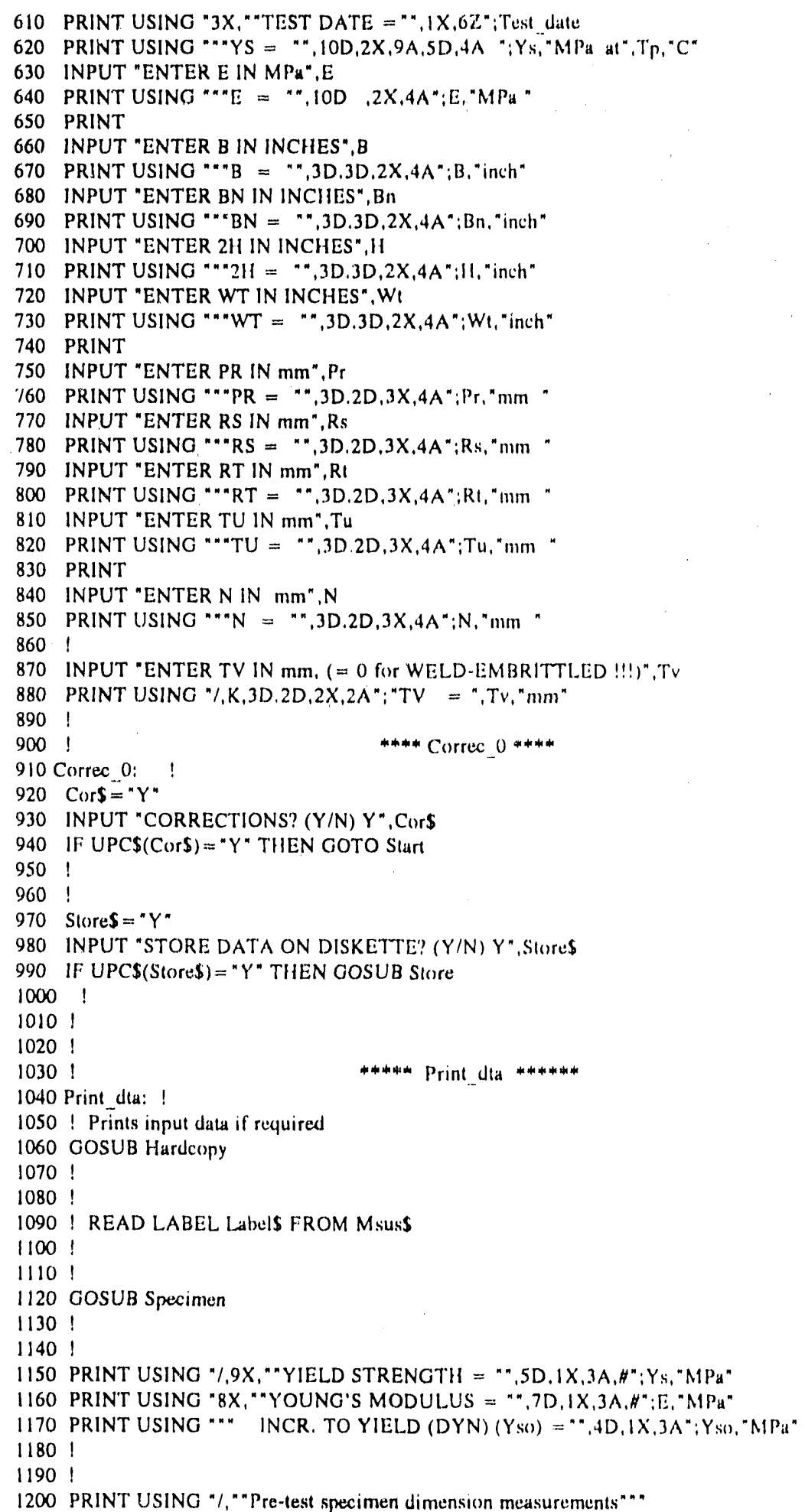




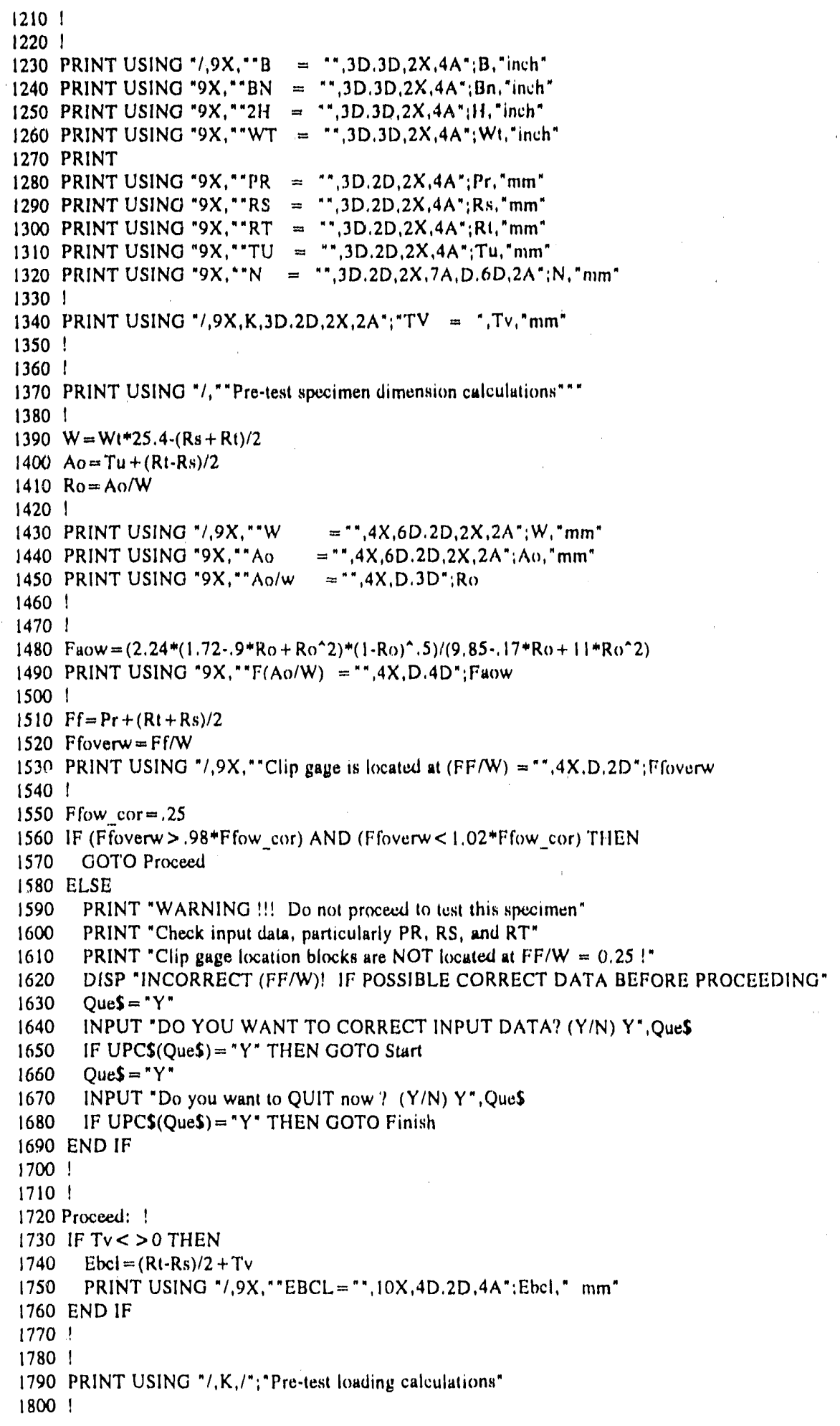




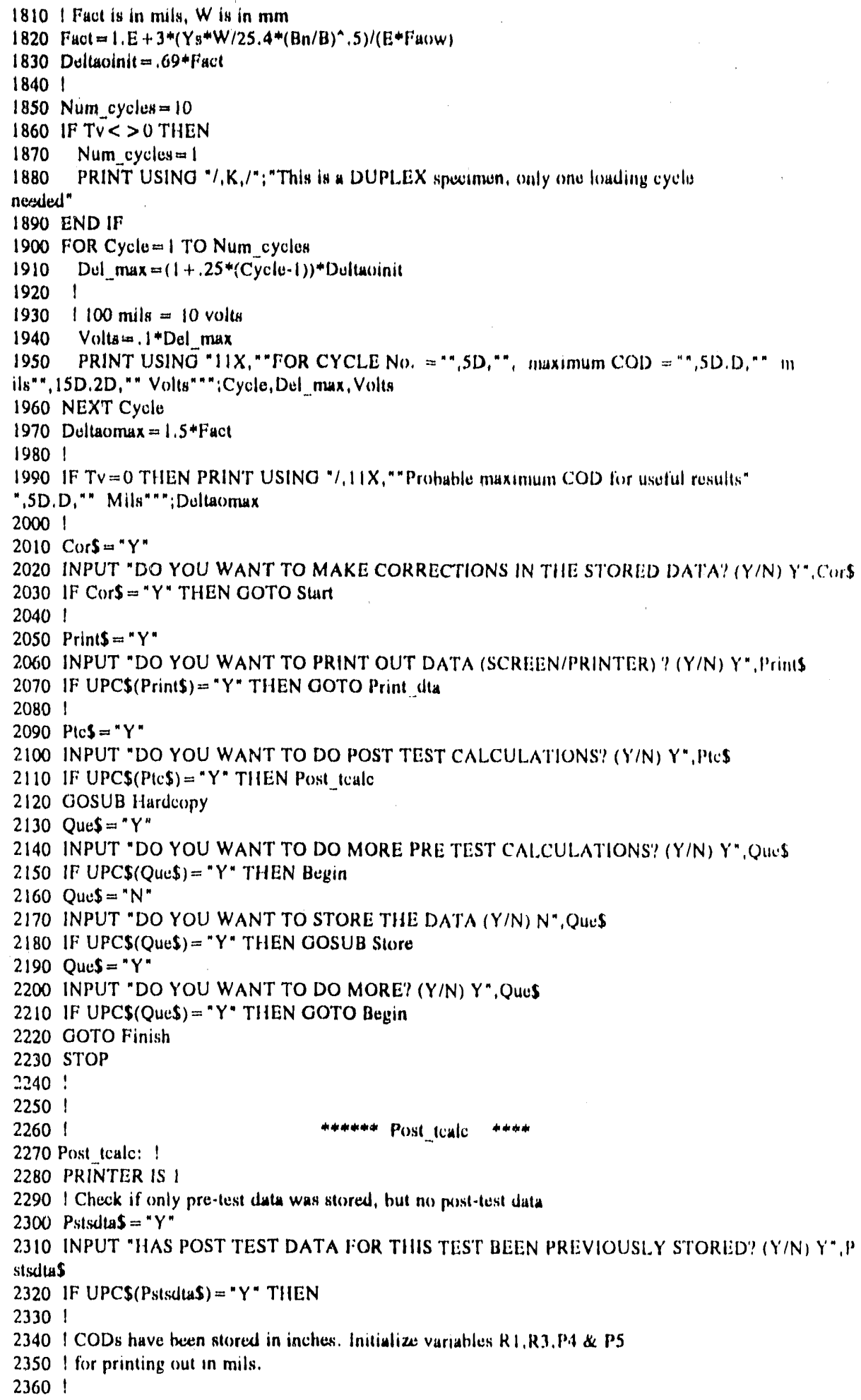




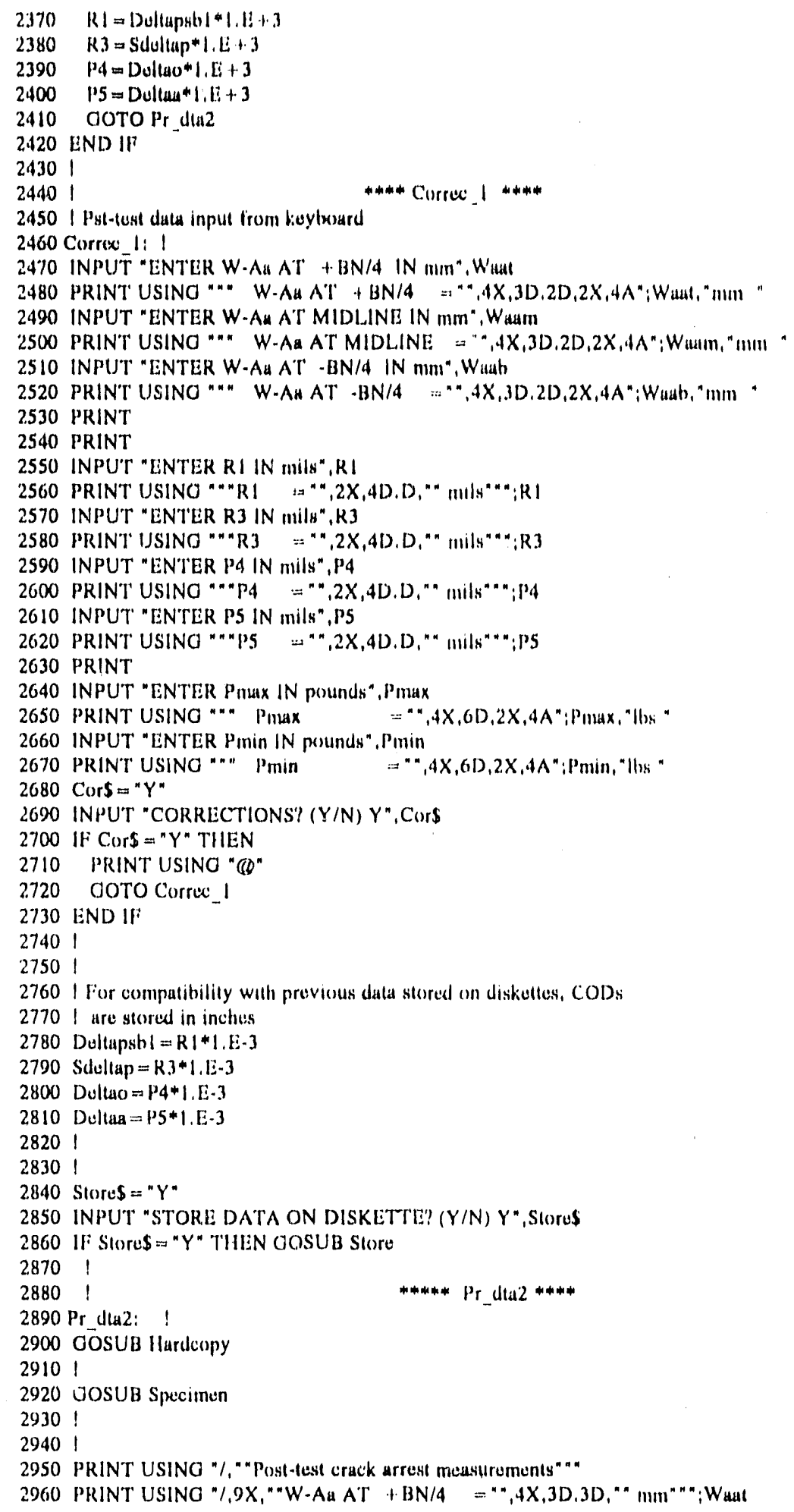


2970 PRINT USINO "9X," "W-Au AT MIDLINE "a ",4X,3D,3D," "mm" "iWHaIn 2980 PRINT USING "9X," "W.Au AT -BN/4 r: " "4X,3D,3D," " mm" "iWush

29901

30001

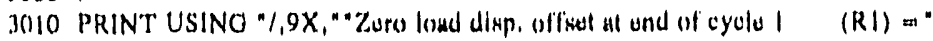

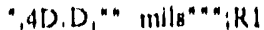

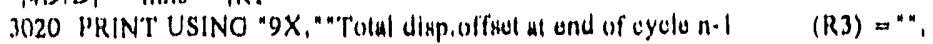

iIJ. D, " milla" ":R3

1030 PRINT USINC "9X," "Displacument at onsel of unstablo crack growith (PA) $=$ ", 4D.D," "mils" "iP4

I040 PRINT USING "9X," "Dlsplacement approx, I a afler arrest $\quad$ (P5) $=$ " ",

HD, D," " mila" "*;PJ

30501

$30 \times 0)$

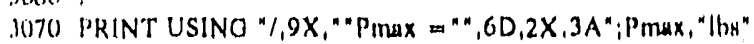

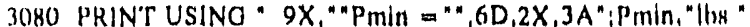

$3090 \mathrm{Rp} \Rightarrow\left(\mathrm{P}_{\max }-\mathrm{P}_{\min } \mathrm{n}\right) / \mathrm{P}_{\max }$

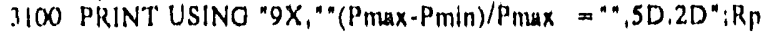

3110 IF RP $>.5$ THEN

3120 PRINT USINO "9X, "Load drop guiduline mul " "

3130 B:LSE

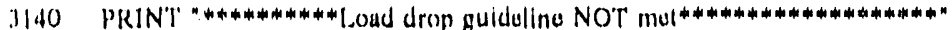

3150 IIND IF

$3160 !$

31701

$.3180 !$

3190 PRINT USINC "/ " "Post-4est crack arrost calculations" " *

$32(0) !$

3210 W

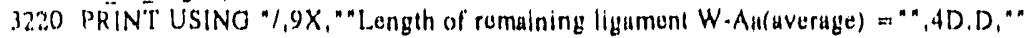
IiHI" " "iW Ha_ "MVg

3230

1240 1 Aa $=$ arrested crack length per AST'M Paragr, 8.6

$3250 \quad \wedge a=W \cdot W_{\text {an_avg }}$

3260 Crukjmp $\Rightarrow$ Aa-Ao

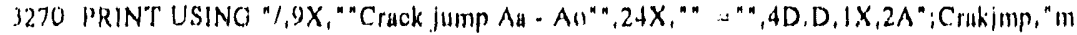
iII"

32801

$32190 !$

3300 I Do and Da are "nel" CODs per ASTM (in m)

$3310 \mathrm{DO}=$ (Deltao-Sdeltap) $* 25,4 * 1, \mathrm{E}-3$

3320 I For duplex specimens, there is only one unload cycle

3330 ! S Dultupsbl (RI) is equal to Sdultap (R3)

33401

$3350 D_{a}=.5 *($ Deltao + Dellata-Dultapsb $1-$ Sdeltap $) * 25.4 * 1, E \cdot 3$

$3360 \mathrm{Rf}=\mathrm{Aa} / \mathrm{W}$

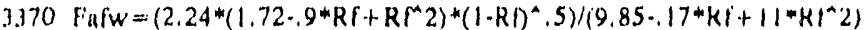

$3380 \mathrm{Fac}=\mathrm{E} *(\mathrm{~B} /(8 \mathrm{~B} * \mathrm{~W} * .001))^{\wedge} .5$

$\left.3390 \mathrm{~K}_{0}\right)=\mathrm{D}_{0} * \mathrm{Fach}^{*} \mathrm{Fac}$

$3400 \mathrm{Kf}=\mathrm{Da} \mathrm{F}^{*} \mathrm{afw} * \mathrm{Fac}$

34101

$342.0 !$

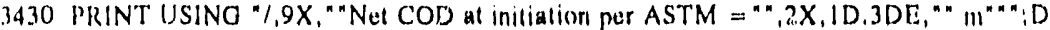
1

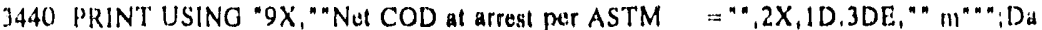

34501

34601

$34 \%$ PRINT USINO "/,9X," Arrested crack length (Aa) $\quad="$, SD.D, " mm

$\cdots$ " Aa

380 PRINT USING "9X," "Fractional arrested crack length $(A a / w)=", 4 X, D, 3 D " ; R f$ 


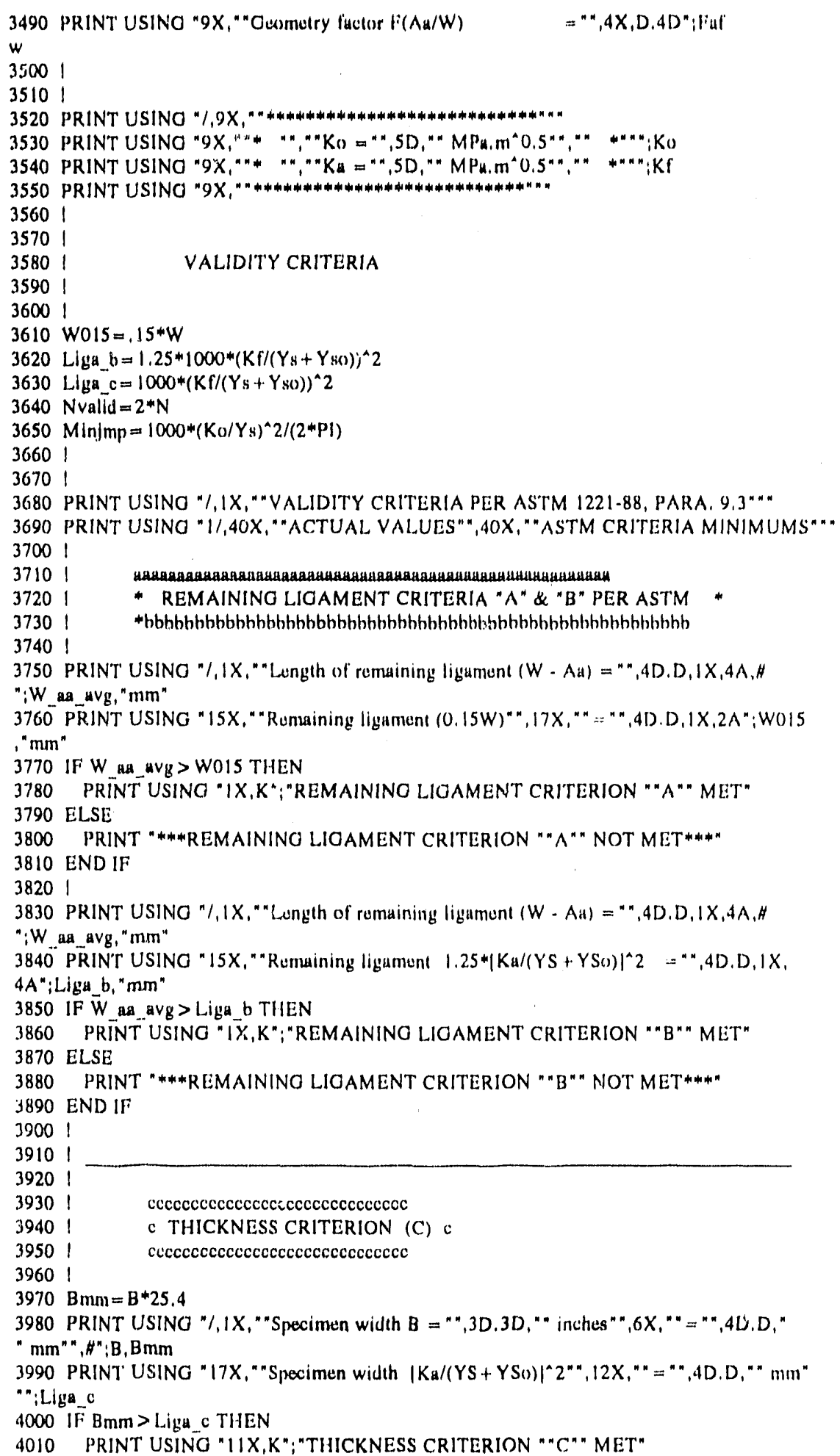




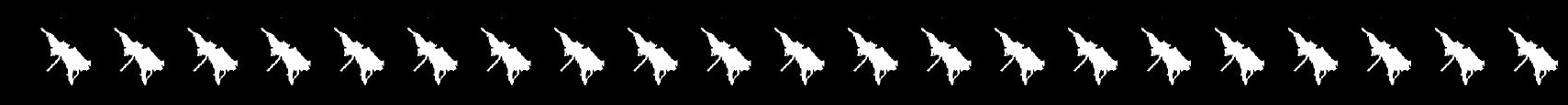




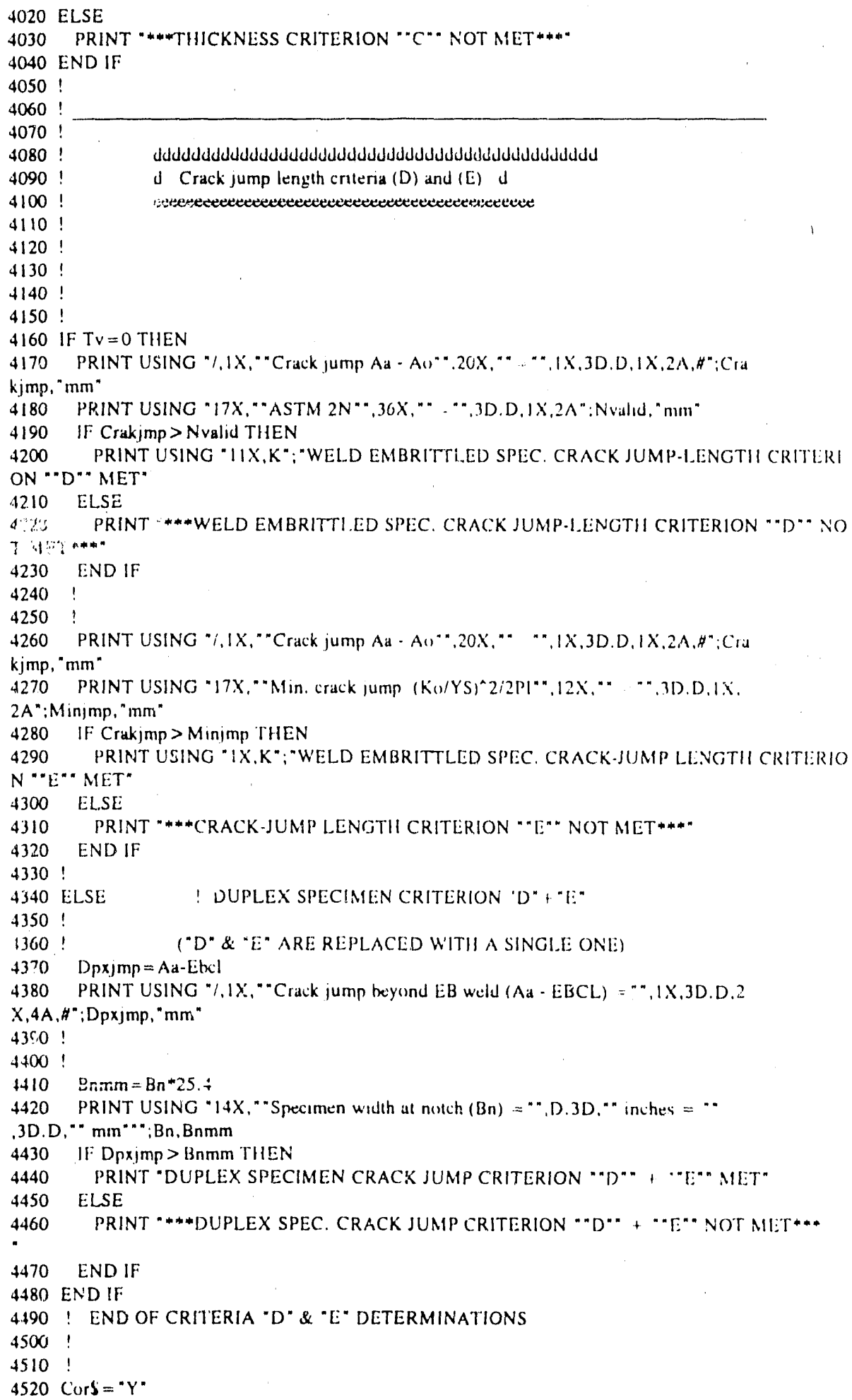




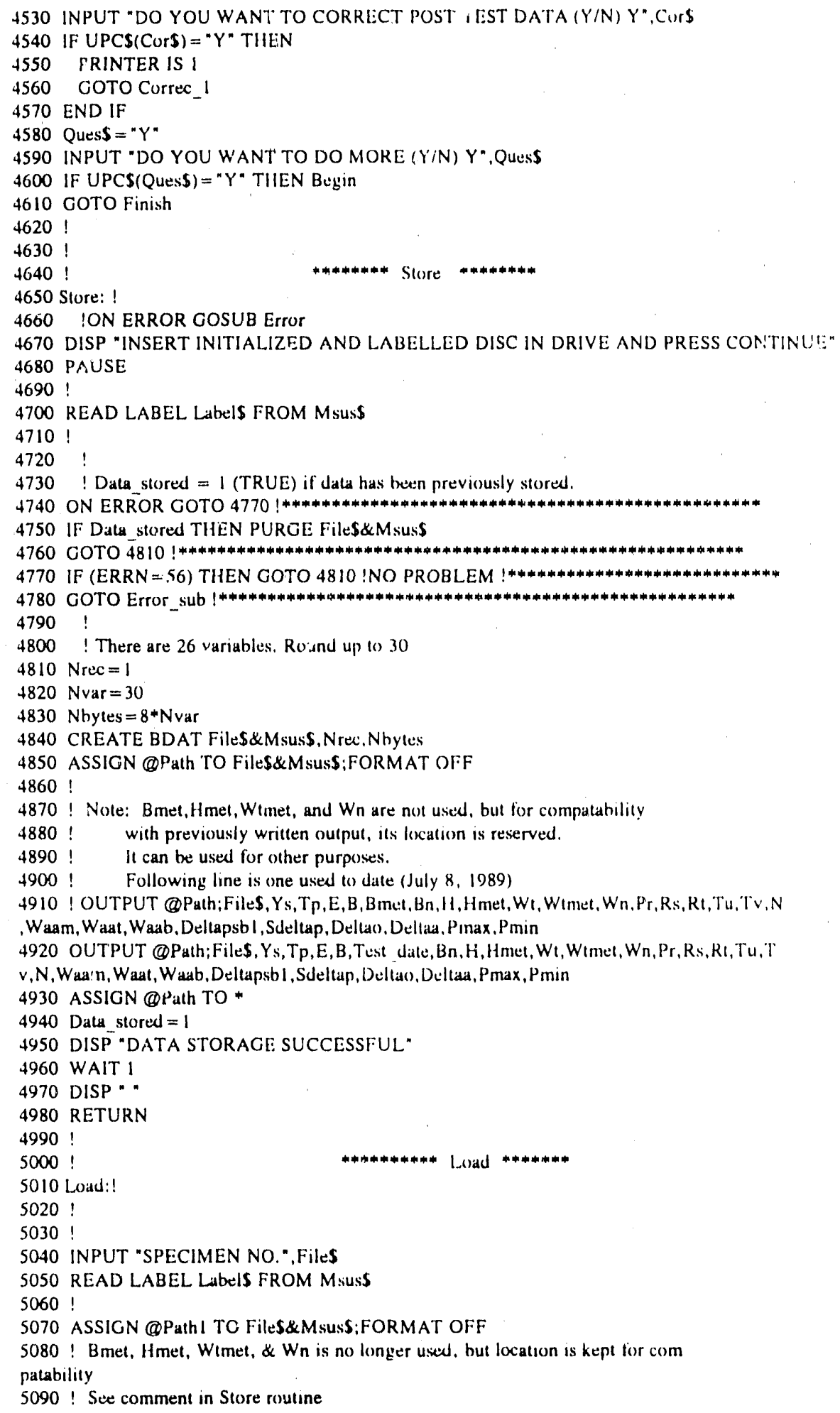


5100 READ LABEL LubelS FROM Mssss:

5110 ENTER @Path1:FileS,Ys,Tp,E,B,Test_Jate,Bn,H,Hmul,Wt,WImu,Wn,Pr,Rs, Rt,Tu,T

$\checkmark, N$, Waam. Waat, Waah, Deltupsbl, Sdeltup, Deiltao, Deltata.Pmux, P'min

5120 ASSIGN @Pathi TO *

5130 ! If data input from storage was successful, the:a data is actually

5140 ! there. Initialize Data stored = I (TRUE)

5150 Data_stored $=1$

5160 DISP "DATA LOAn FROM DISK "\&MAUSS.K" "\&LAbelS\&" SUCCESSFUL"

5170 WAIl' 3

5180 RETURN

$5190 !$

$5200 !$

****** Advance ******

5210 Advance: !

$5220 \mathrm{PS}=$ " $\mathrm{N} "$

5230 INPUT "ADVANCE PAPER? (Y/N) N",PS

5240 IF UPCS(PS) $=$ " $Y$ " THEN PRINT USING "(Q)"

5250 RETURN

$5260 !$

$5270 !$

$5280 !$

5290 Hardcopy:

$5300 \mathrm{HS}=" \mathrm{~N} "$

5310 INPUT "NEED HARDCOPY? (Y/N) N".11S

5320 IF UPCS $(H \$)=" Y "$ THEN

5330 PRINTER IS 9

5340 GOSUB Advance

5350 PRINT USINO " $K, 2 X, K, 3 X, K, 2 X, K$ "; "CRACK ARREST COMPUTER CODE CA TIEST " $\$ B a$

nners, "Time of this run: "DATES(TIMEDATE), TIMES(TIMEDATE)

5360 ELSE

5370 PRINTER IS I

5380 END IF

5390 RETURN

$5400 !$

$5410 !$

**** Error_suh ****

5420 Error sub: !

5430 PRINT ERRMS

S440 PRINT "PGSSIBLE INPUT DATA ERROR: CHECK INPUT"

5450 DISP "HIT CONTINUE"

5460 PAUSE

5470 GOTO Begin

5480 !

$5490 !$

5500 Specimen: !

5510 PRINT USING "2/,1X," "SPECIMEN NO, " ",7A,4"; FiluS

5520 IF TV $<>0$ THEN

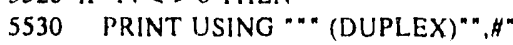

5540 ELSE

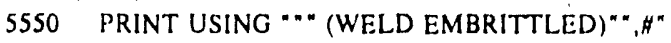

5560 END IF

$5570 !$

$5580 !$

5590 PRINT USING "9X." "TEST TEMPERATURE $=" *, 4 D, 1 X, A, \# " ; T_{p}, \mathrm{C}^{*}$

5600 PRINT USING "3X.K.H";" from disk "\&Lubels

5610 PRINT USING "3X." "TEST DATE $=" n, 1 X, 6 Z^{n}:$ Test_late

5620 RETURN

5630 !

$5640 !$

5650 ! Dpx we: ! This subprogam prints out whether specumen

$5660 \quad !$ is a duplex or weld-embrittled trpe and value of $T$.

$5670 \quad$ Note that $T V$ is set equal to zero for weld-embrittled 


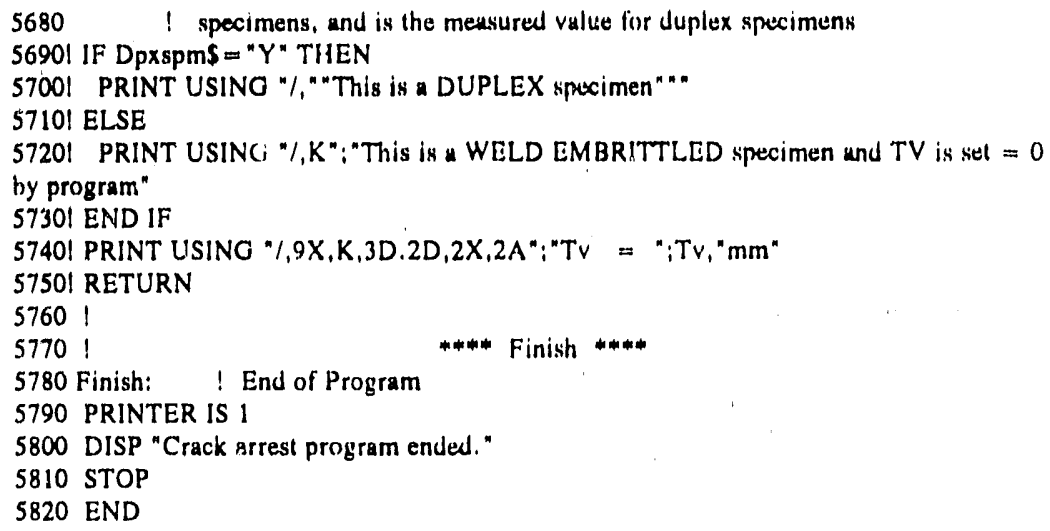


APPENDIX C

YOUNG'S MODULUS

USED IN THE EVALUATION OF THE CRACK ARREST DATA 
Young's modulus is used to calculate the stress intensity factors $K_{o}$ and $K_{a}$, both of which are directly proportinnal to the value of $E$ lised [see Eq. (C..1)]. Young, "s modulus together with the yield strength are used to calculate the had fnctement for the loading and unloading cycles for weld-embrittled type specimens as well as the validity criteria.

The Young's modulus used to evaluate both unirradiated and irradiated crack arrest data is calculated from the following expression [1]:

$$
E=207.2-0.0571 \mathrm{~T}
$$

where $\mathrm{E}$ - Young's modulus in $\mathrm{GPa}$, and $\mathrm{T}$ - temperature in ${ }^{\circ} \mathrm{C}$. Reference [1] in turn cites Subsection NB 2300, ASME Boiler and Pressure Vessel Code, Sect. III. The current version of NB 2300 does not give this equation, so it is of interest to compare it with values in the recent edition of the ASME Code [2]. Figure C.1 and Table C.1 compare Young's modulus calculated at the tabular temperatures given in the American Society of Mechanical Engineers Code. In the temperature range used for testing both the unirradiated and irradiated crack arrest specimens, -75 to $100^{\circ} \mathrm{C}, \mathrm{Eq}$. (C.1) gives values that are about 28 higher than those in Ref. [2]. It is planned to measure Young's modulus for the weldments and reanalyze the crack-arrest data.

Table C.1. Comparison of Young's modulus calculated using values given in the ASME Code and

Eq. (C.1)

\begin{tabular}{cccc}
\hline $\begin{array}{c}\text { Temperature } \\
\left({ }^{\circ} \mathrm{C}\right)\end{array}$ & \multicolumn{2}{c}{ Young's modulus (GPa) } & \multirow{2}{*}{$\begin{array}{r}\text { Difference } \\
{[(\mathrm{E}-\mathrm{A}) / \mathrm{A}]}\end{array}$} \\
\cline { 2 - 3 } & ASME (A) & EPRI (E) & \\
\hline-198 & 216.5 & 218.5 & 1 \\
-129 & 212.4 & 214.6 & 1 \\
-73 & 208.2 & 211.4 & 2 \\
21 & 203.4 & 206.0 & 1 \\
93 & 198.6 & 201.9 & 2 \\
169 & 195.1 & 198.7 & 2 \\
204 & 191.0 & 195.5 & 2 \\
260 & 188.2 & 192.4 & 2 \\
316 & 184.1 & 189.2 & 3 \\
371 & 175.8 & 186.0 & 6 \\
427 & 166.9 & 182.9 & 10
\end{tabular}

NOTE:

ASME = Anerican Society of Mechanical Engineers EPRI = Electric Power Research Institute 
1. W. L. Server, J. W. Sheckherd, and R. A. Wullaert, Electric Power Research Institute, Palo Alto, Calif., Fracture Toughness Data for Ferritic Nuclear Pressure Vessel Materials, EPRI NP-119, Apri1 1976.

2. ASME Boiler and Pressure Vessel Code, Sect. 'II, Div. 1, Appendix I, Tabl I-6.0, American Society of Mechanical Engineers, July 1, 1989. 
APPENDIX D

TYPICAL OUTPUT FROM CA TEST

FOR A WELD-EMBRITTLED AND DUPLEX SPECIMEN 
CRACK ARREST COMPUTER CODE CA_TEST Vursion S.1 Ruvised Fubruary 14, 1990) Timu of this run: 12 Sup 1990 16:02:48 SPECIMEN NO. A72WAR (WELD EMBRITTLED) TEST TEMPERATURE $=.30 \mathrm{C}$ from disk CANO1 TEST DATE $=$ OCO YIELD STRENOTH $=539 \mathrm{MPa}$ "YOUNO'S MODULUS $=208900 \mathrm{MPa}$ INCR. TO YITLD (DYN) $(Y$ s(1) $=205 \mathrm{MPa}$

Pre-test specimen dimension measurements

$$
\begin{aligned}
& B=1.000 \text { inch } \\
& B N=.743 \text { inch } \\
& 2 H=5.999 \text { inch } \\
& W T=6.000 \text { inch } \\
& P R=6.35 \mathrm{~mm} \\
& R S=10.69 \mathrm{~mm} \\
& R T=40.55 \mathrm{~mm} \\
& T U=28.33 \mathrm{~mm} \\
& N=11.38 \mathrm{~mm} \\
& T V=0.00 \mathrm{~mm}
\end{aligned}
$$

Pre-test specimen dimension calculations

$$
\begin{aligned}
& W=126.78 \mathrm{~mm} \\
& \text { Ao }=43.27 \mathrm{~mm} \\
& A 0 / W=.341 \\
& F\left(A O / W^{\prime}\right)=.2511 \\
& \text { Clip gage is located at }(\mathrm{FF} / \mathrm{W})=.25
\end{aligned}
$$

Pre-test loading calculations

FOR CYCLE NO, $=1$, maximum COD $=30.5$ mils FOR CYCLE No. $=2$, maximum COD $=38.1$ mils FOR CYCLE NO, $=3$, maximum COD $=45.8$ mils FOR CYCLE No, $=4$, maximum COD $=53.4$ mils FOR CYCLE No, $=5$, maximum COD $=61.0$ mils FOR CYCLE No. $=6$, maximum COD $=68.6$ mils FOR CYCLE No $=7$, maximum COD $=76.3$ mils FOR CYCLE No. $=8$, maximum COD $=83.9$ mils FOR CYCLE No, $=9$, maximum COD $=91.5$ mils FOR CYCLE No, $=10$, maximum COD $=99.1 \mathrm{mils}$ Probable maximum COD for useful results 66.3 Mils
3.05 Volts 3.81 Volts 4.58 Volts 5.34 Volts $0.10 \mathrm{Volits}$ $6.86 \mathrm{Volts}$ 7.63 Volts $8.39 \mathrm{Volts}$ 9.15 Volts 9.91 Volls 
CRACK ARREST COMPUTER CODE CA..TEST Version 5.1 Ruviked Fubruary 14, 1990) Time of this run: 12 Súp 1990 16:03:09 SPECIMEN NO, A72W48 (WELD EMBRITTLED) TEST TEMPERATURE $=-30 \mathrm{C}$ from disk CANOI TI:ST DATE: $\because$ (KWO Pust-test crack arrest measurements

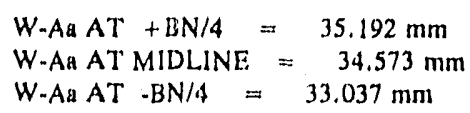

VALIDITY CRITERIA PER ASTM 1221-88, PARA. 9.3

ACTUAL VALUES

Length of remaining ligament $(W-A a)=34.3 \mathrm{~mm}$ REMAINING LIGAMENT CRITERION "A" MET

Length of remaining ligament $(W \cdot A a)=34.3 \mathrm{~mm}$ REMAINING LIGAMENT CRITERION "B" MET

Specimen width $B=1.000$ inches $\quad=25.4 \mathrm{~mm}$ THICKNESS CRITERION "C" MET

\section{ASTM CRITERIA MINIMIUMS}

Remuining ligument $(0.15 \mathrm{~W})$

$=19.0 \mathrm{~mm}$

Remaining ligument $1.25 * \mid K a /\left(Y S+\left.Y S(1)\right|^{\wedge} 2=21.5 \mathrm{~mm}\right.$

Specimen width $\mid \mathrm{Ka} /\left(Y S+\left.Y S(1)\right|^{\wedge} 2=17.2 \mathrm{~mm}\right.$
Crack jump $A a-A o$
$=49.2 \mathrm{~mm}$
ASTM $2 \mathrm{~N}$
WELD EMBRT
ITTLED SPEC.
$=49.2 \mathrm{~mm}$
$22.8 \mathrm{~mm}$
Crack jump Aa - Ao $=49.2 \mathrm{~mm}$
Min. crack jump $\left(k^{*} u / Y S\right)^{\wedge} 2 / 2 P I$
$=20.7 \mathrm{~mm}$
WELD EMBRITTLED SPEC, CRACK-JUMP LENGTII CRITERION "E" MET 
CRACK ARREST COMPUTER CODE CA_TEST Varuion 5.1 Ruvised Fubruary 14, 1990) Time wh his run: 12 Sup 1990) 10:06107

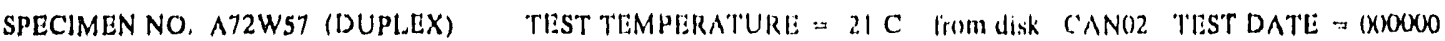

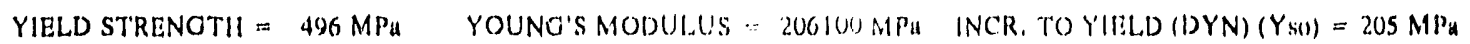

Pre-test specimen dimension medsurements

$$
\begin{aligned}
& B=1.298 \text { inch } \\
& B N=676 \text { inch } \\
& 2 H=6.000 \text { inch } \\
& W T=6.000 \text { inch } \\
& P R=6.35 \mathrm{~mm} \\
& R S=9.40 \mathrm{~mm} \\
& R T=41.13 \mathrm{~mm} \\
& T U=27.07 \mathrm{~mm} \\
& N=1.43 \mathrm{~mm} \\
& T V=42.66 \mathrm{~mm}
\end{aligned}
$$

Pre-lest specimen dimension calculations

$$
\begin{aligned}
& W=127.14 \mathrm{~mm} \\
& \mathrm{AO}_{\mathrm{A}}=42.94 \mathrm{~mm} \\
& \mathrm{~F} / \mathrm{W}=1 \mathrm{~W})=.338 \\
& \text { Clip gage is located al }(\mathrm{FF} / \mathrm{W})=.2525 \\
& \mathrm{EBCL}==\quad 5.53 \mathrm{~mm}
\end{aligned}
$$

Pre-test loading calculations

This is a DUPLEX specimen, only one Joading cycle needed

FOR CYCLE NO, $=1$, maximum COD $=28.5 \mathrm{muls} \quad 2.85$ Vollts 
CRACK ARREST COMPUTER CODE CA_TEST Vurviun 3.1 Ruvimed Futhruary 14, 1990) Timu of thin run: 12 Sup 1990 10105103

SPECIMEN NO, AT2WS7 (DUPLEX) TEST TEMPERATURE $=21 \mathrm{C}$ from dilkK CANO2 TEST DATE $=000000$

Post-test orack arrest meusurements

$W$-Aa AT +BN/4 $=54.341 \mathrm{~mm}$
$W-A_{a}$ AT MIDLINE $=54.484 \mathrm{~mm}$
$W-A_{a}$ AT -BN/4 $=56.693 \mathrm{~mm}$

Zero load disp, offset at end of cycle 1

Total disp, offset at end of oycle $n-1 \quad(R 3)=0.0$ mils

$(R 1)=.7 \mathrm{mils}$

Displacement at onset of unstatilo cruck grow/h $(\mathrm{PA})=50.5$ mils

Dlsplacement upprox. I \& after arrest $\quad(P 5)=51.8$ mils

$P \max =17600 \mathrm{lbs}$

$P \min =1000 \mathrm{lbs}$

$(P \max -P \min ) / P \max =.94$

Load drop guideline mot

Post-test crack arrest calculations

Length of remaining ligament W-Au(averages) $=55.2 \mathrm{~mm}$

Crack jump $A a-A O$

$=29.0 \mathrm{~mm}$

Net COD at initiation per ASTM $=1.283 \mathrm{E}-03 \mathrm{~m}$

Net COD at arrest per ASTM $=1.290 \mathrm{E}-03 \mathrm{~m}$

Arrested crack length $(A a) \quad=72.0 \mathrm{~mm}$

Fractional arrested crack length $(\mathrm{Aa} / \mathrm{W})=\quad .55,6$

Ceometry factor $\mathrm{F}(\mathrm{A} a / \mathrm{W})$

$=.1701$

* $\mathrm{Ko}_{0}=216 \mathrm{MPa} \cdot \mathrm{m}^{\wedge} 0.5$ *

* $\mathrm{Ka}_{\mathrm{a}}=146 \mathrm{MPa} \cdot \mathrm{m}^{\wedge} 0.5$ *

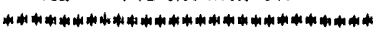

VALIDITY CRITERIA PER ASTM 1221-88, PARA. 9.3

ACTUAL VALUES

ASTM CRITE:IIA MINIMUMS

Length of remaining ligament $(W-A a)=55.2 \mathrm{~mm}$ REMAINING LIOAMENT CRITERION "A" MET

\author{
Remaining ligament $(0.15 \mathrm{~W}) \quad=19.1 \mathrm{~mm}$ \\ Kemainung ligament $1.25 *|\mathrm{Ka} /(Y S+Y S())|^{\wedge} 2=54.5 \mathrm{~mm}$ \\ Specimen width $|\mathrm{Ka} /(Y S+Y S())|^{\wedge} 2 \quad=43.6 \mathrm{~mm}$
}

Length of remaining ligament $(W-A A)=55.2 \mathrm{~mm}$

REMAINING LIGAMENT CRITERION "B" MET

Specimen width $B=1298$ ir.shes $=33.0 \mathrm{~mm}$
***THICKNESS CRITERION "C" NOT MET**+*

Spocimen width at notch $(B n)=.976$ inches $=24.8 \mathrm{~mm}$

Crack jump theyond $E B$ weld $(A a-E B C L)=13.4 \mathrm{~mm}$ * *DUPL.EX SPEC. CRACK JUMP CRITERION "D" + "I:" NOT MET*** 
APPENDIX E

S'TRTY CHAR'IS AND FRAC'IURE SURFACES 


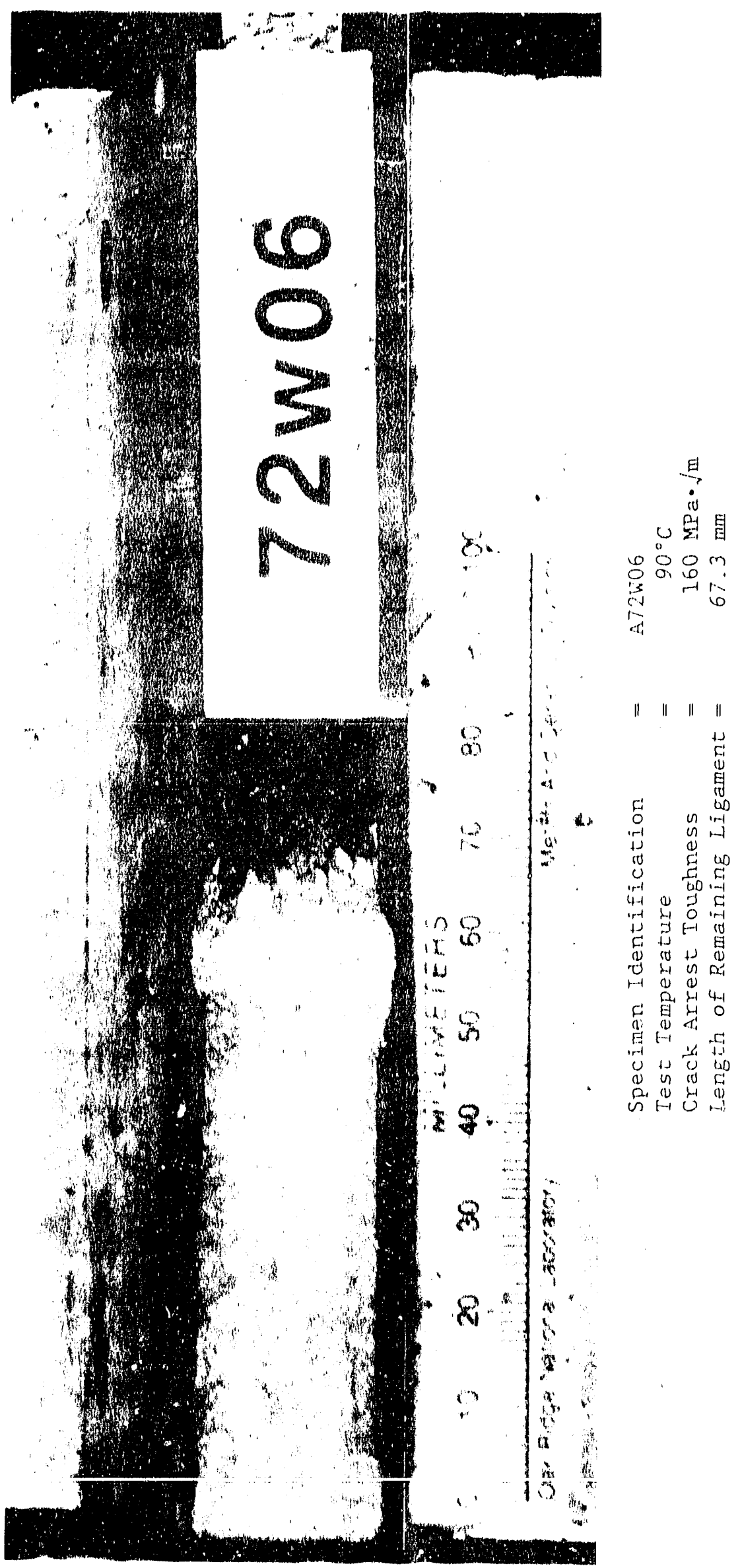



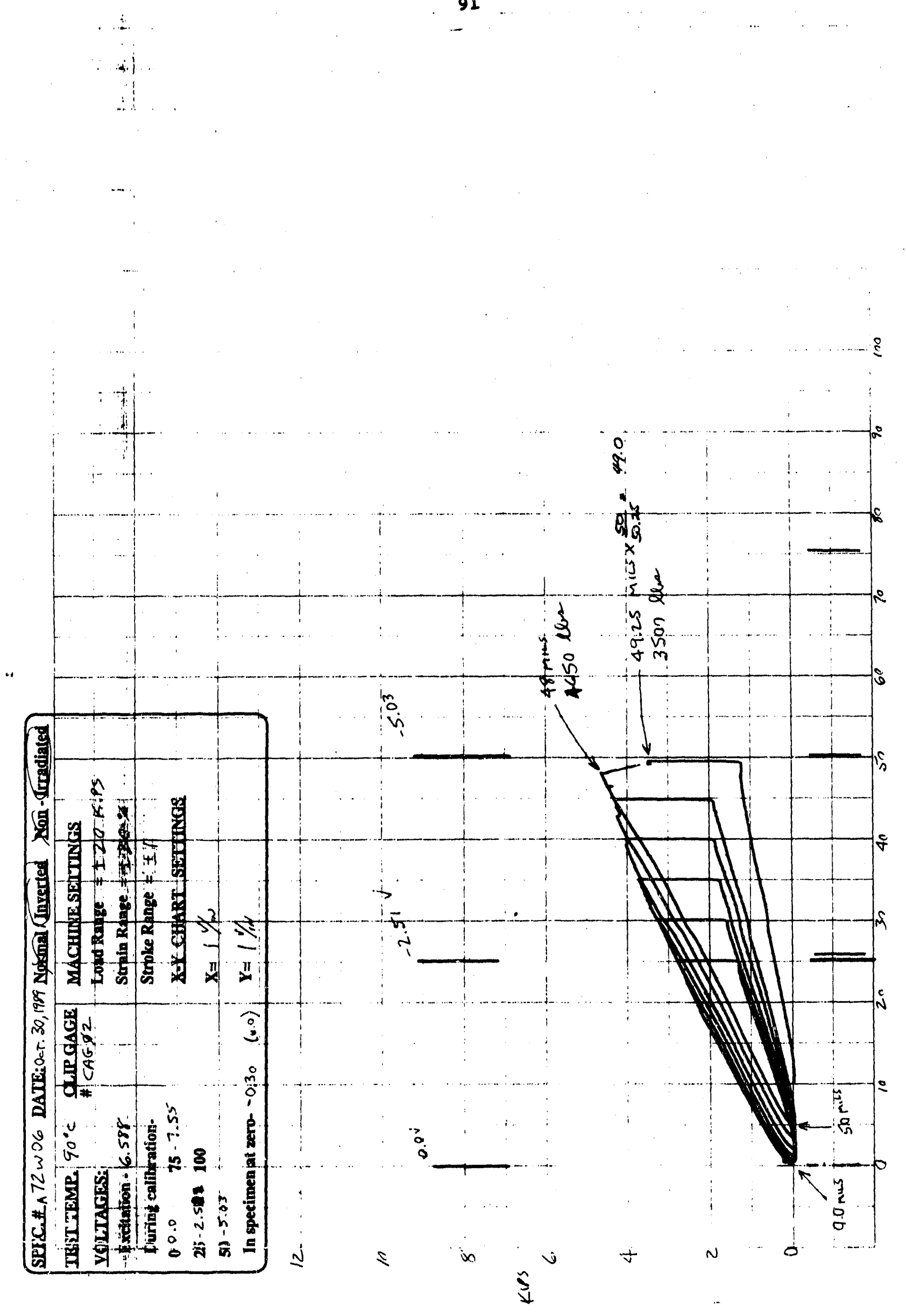


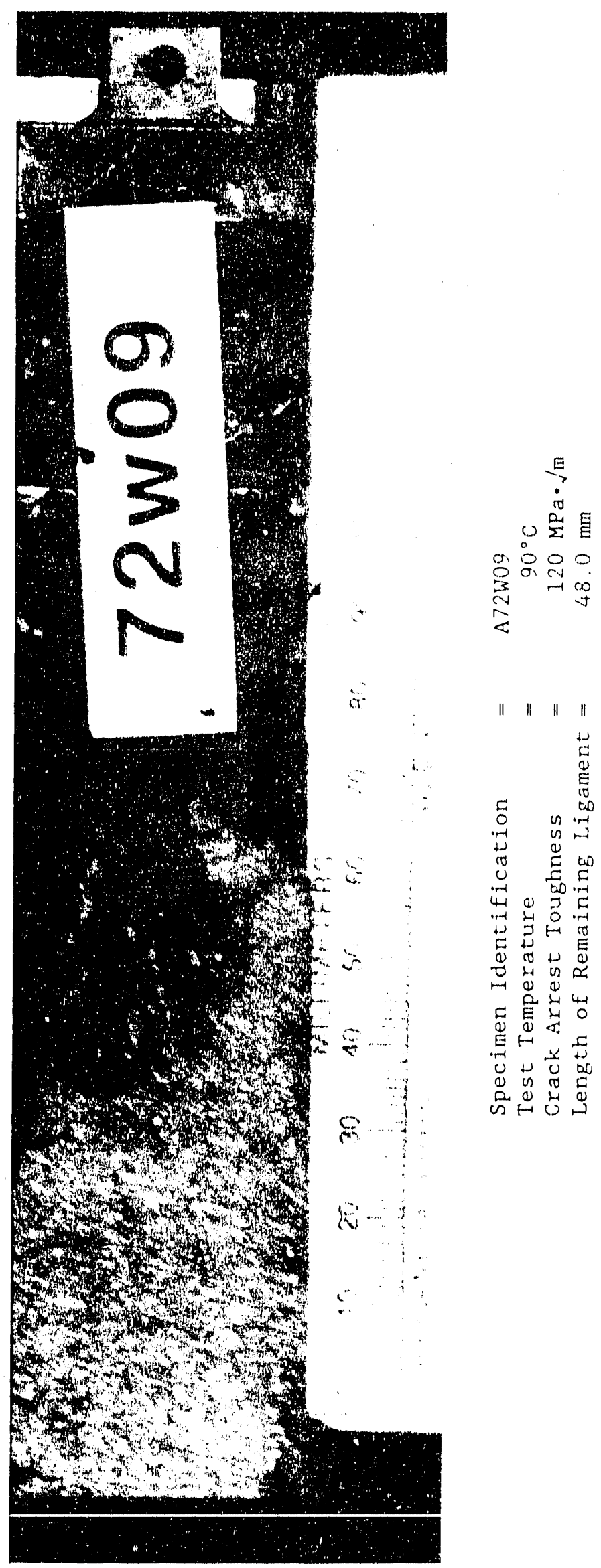




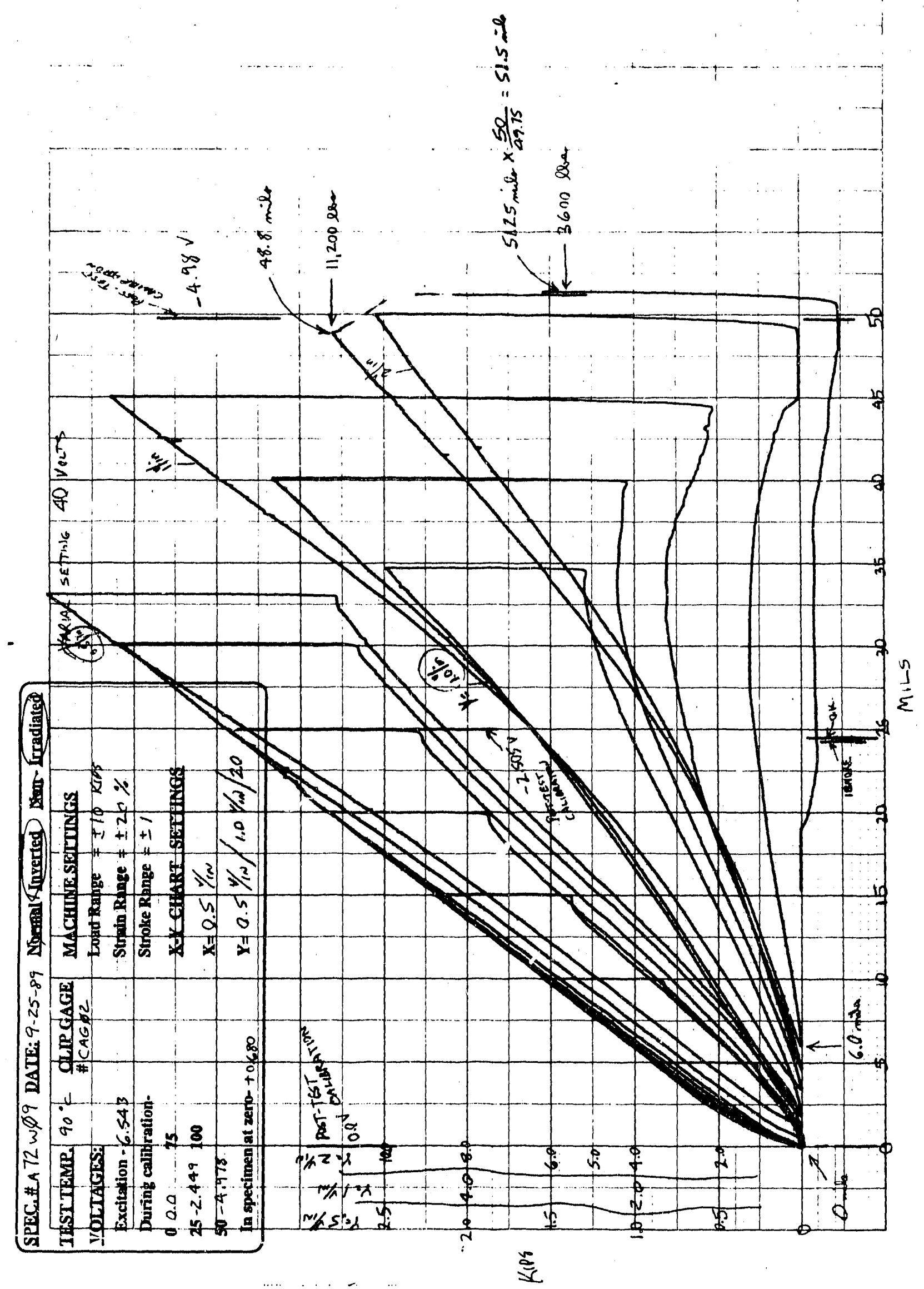




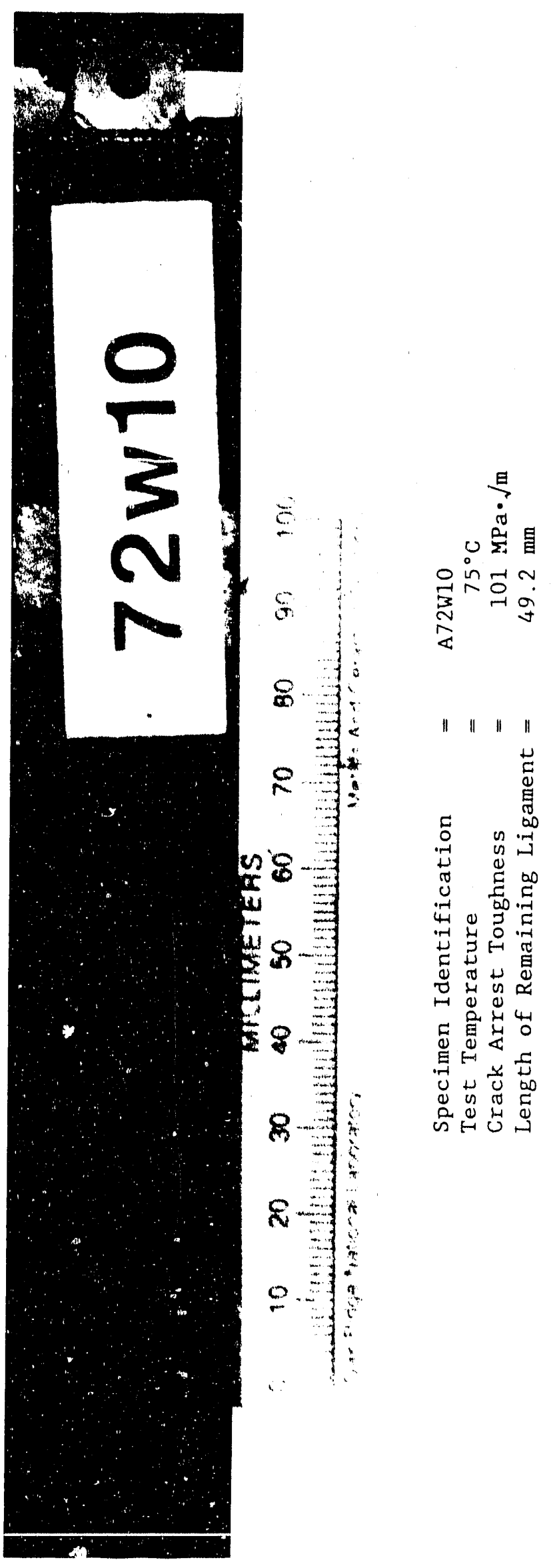



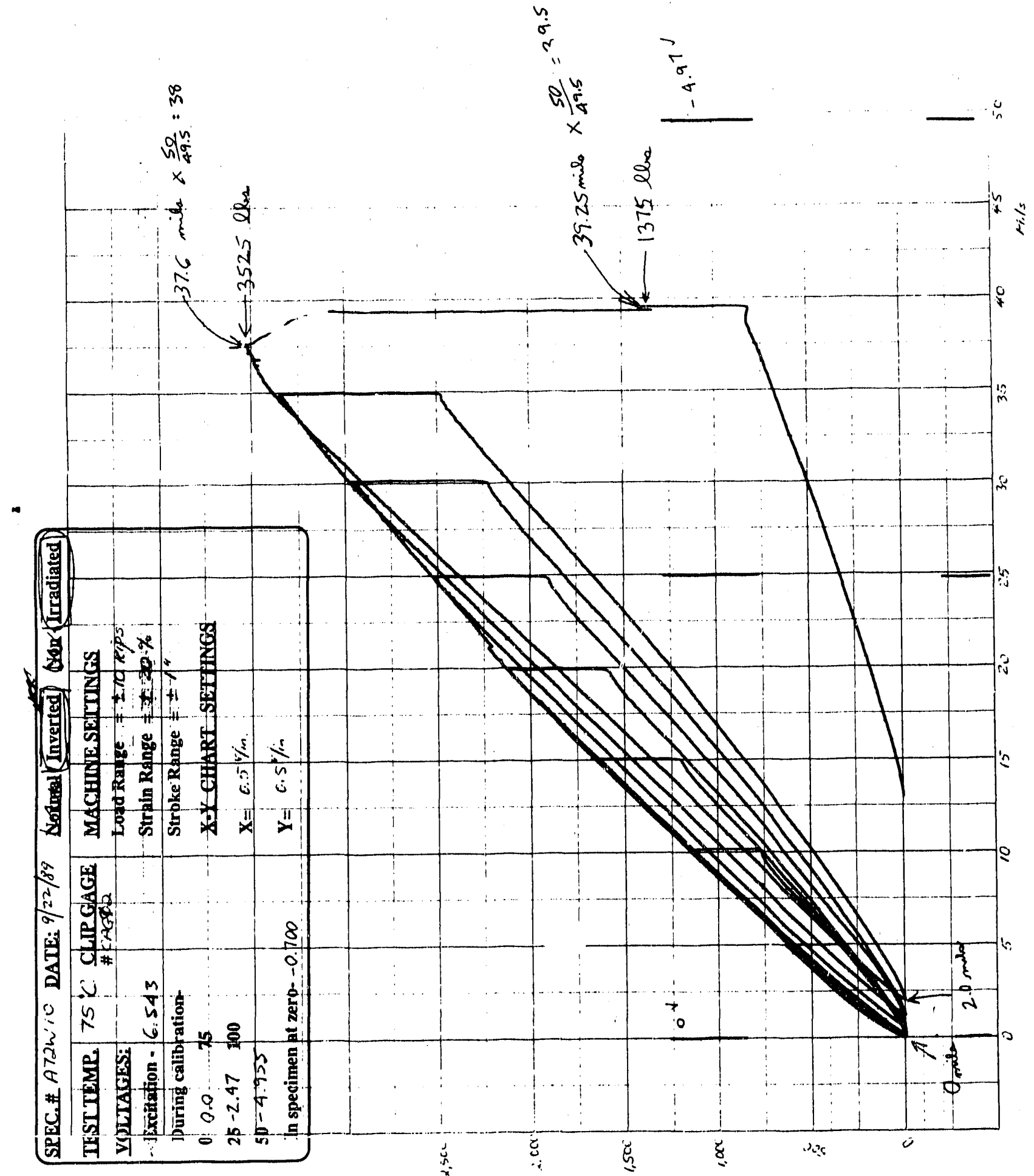


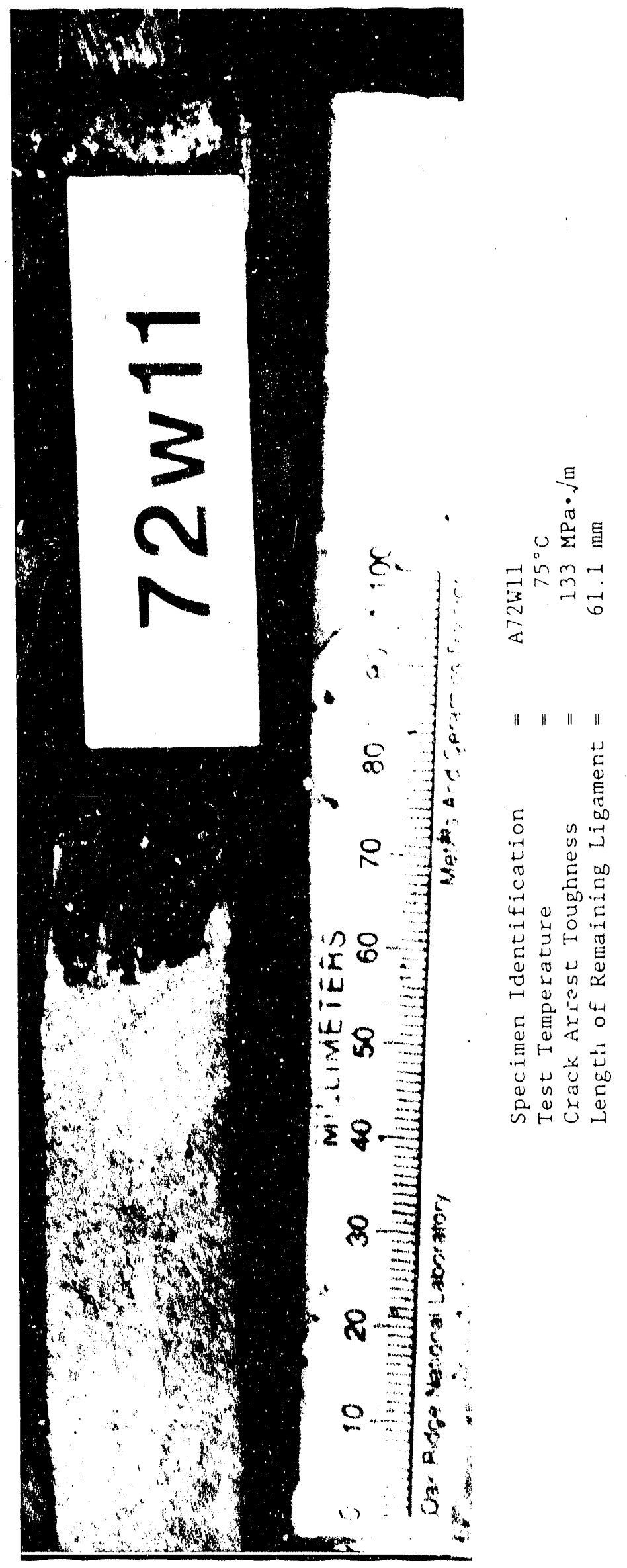



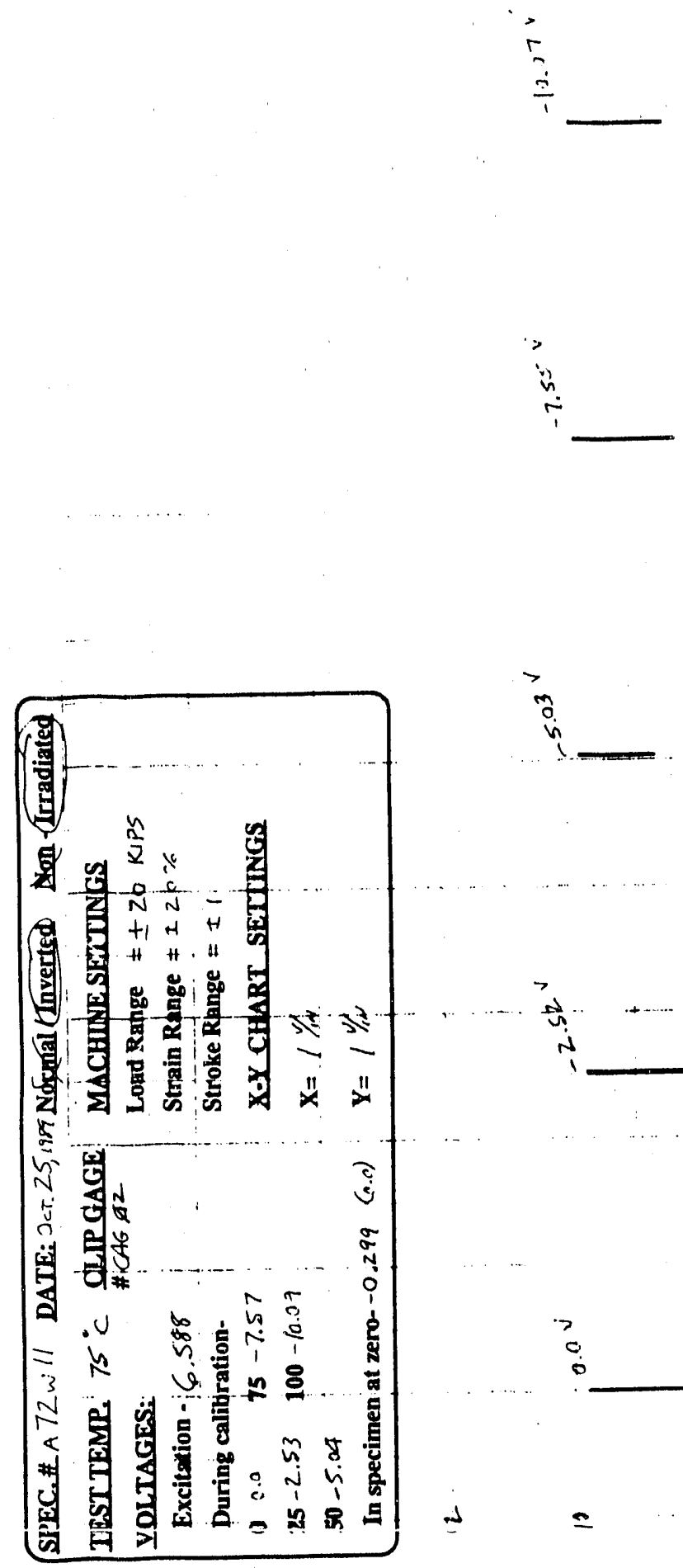

3
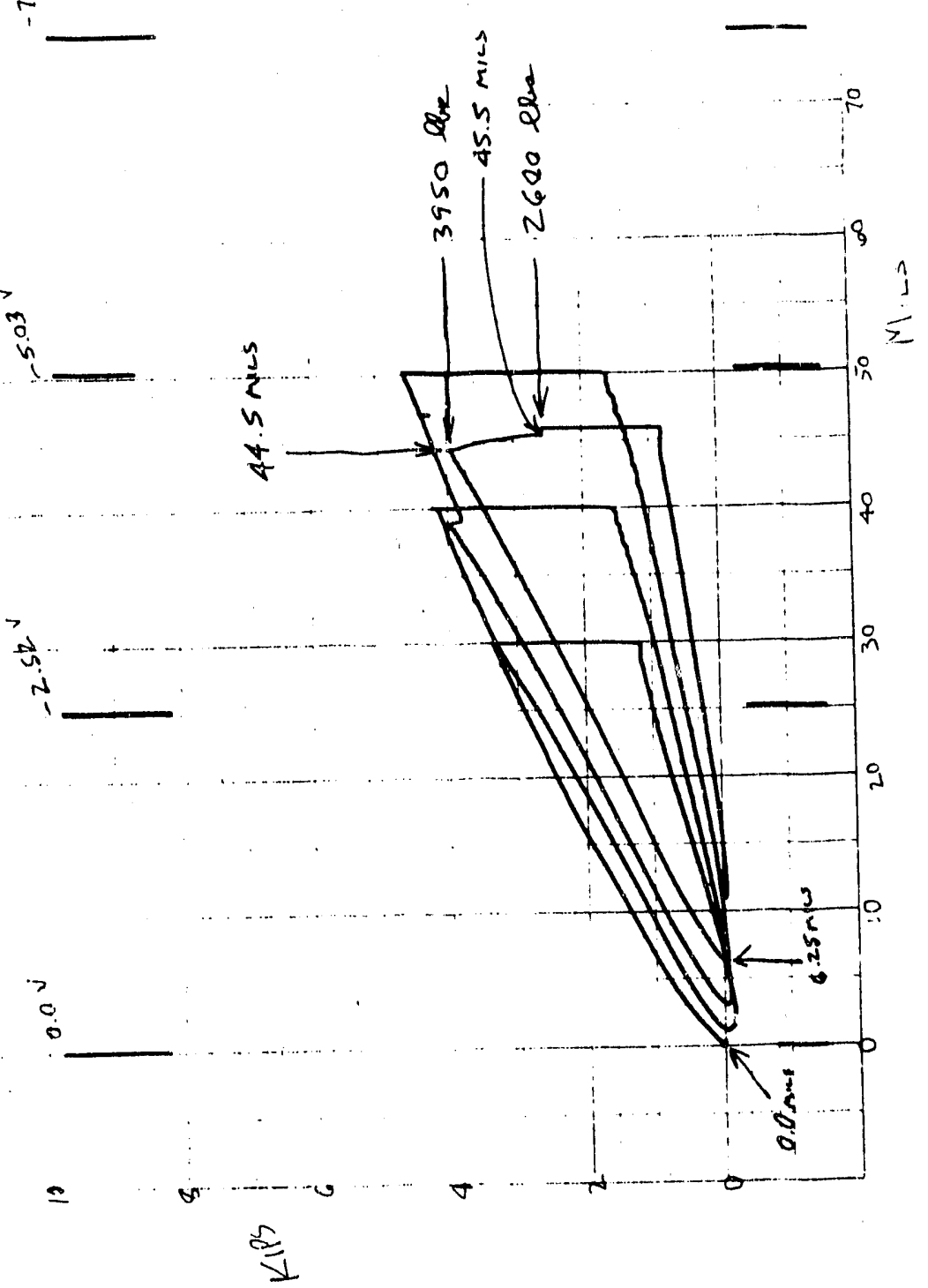


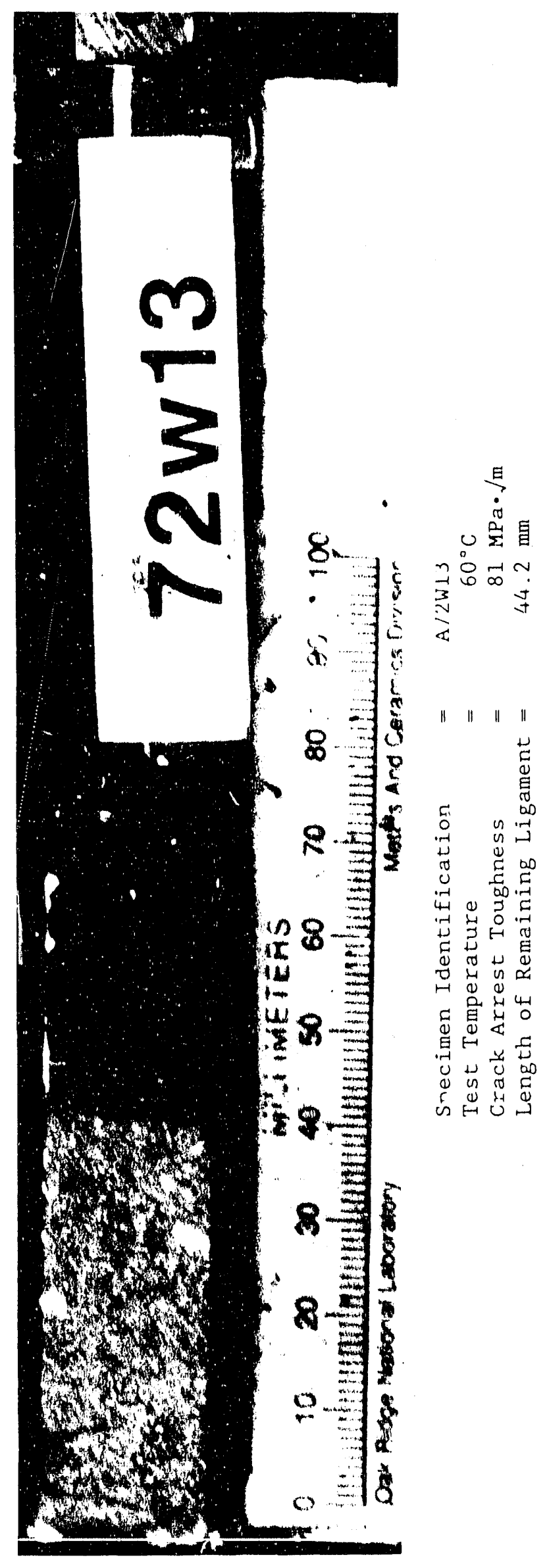




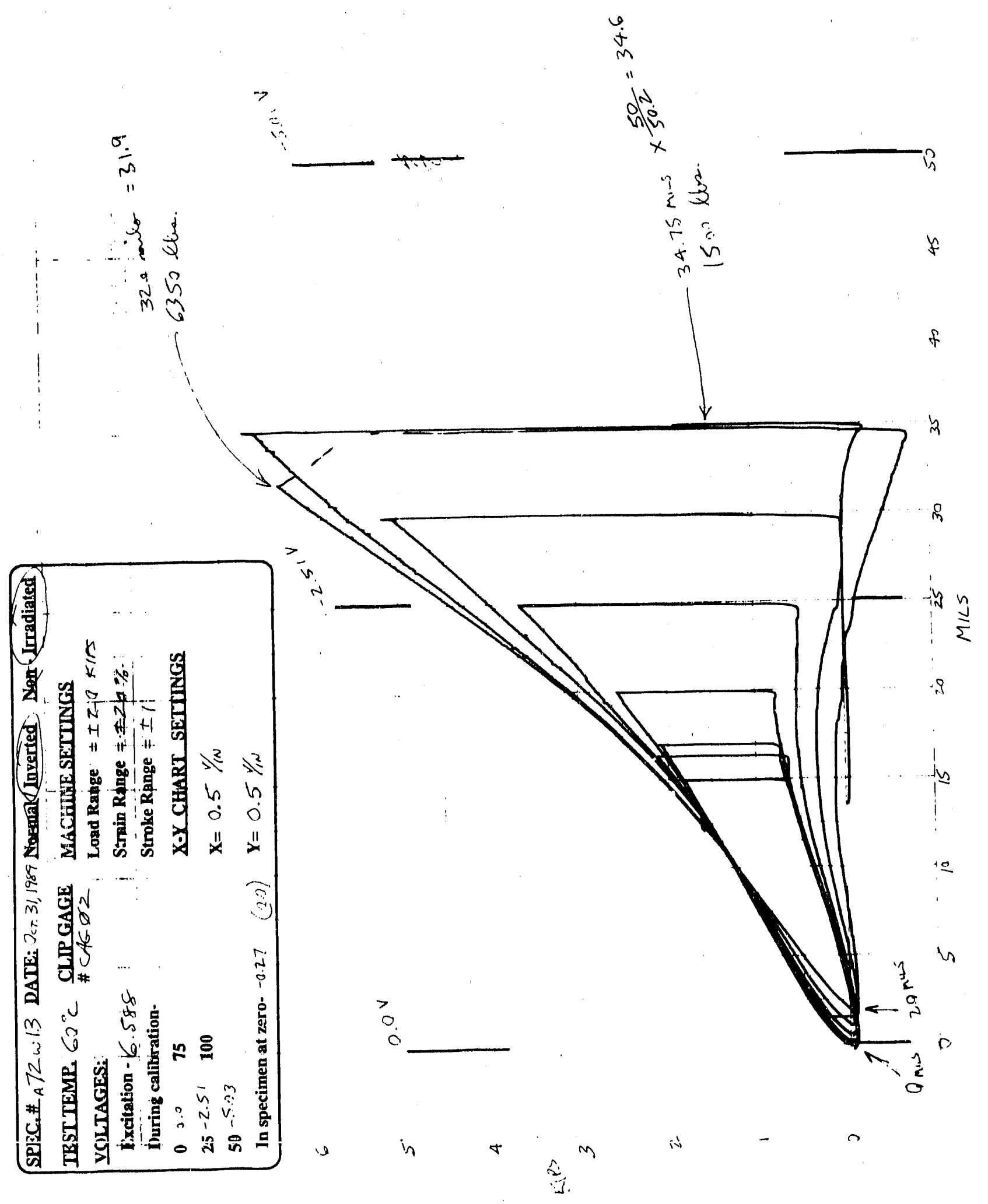




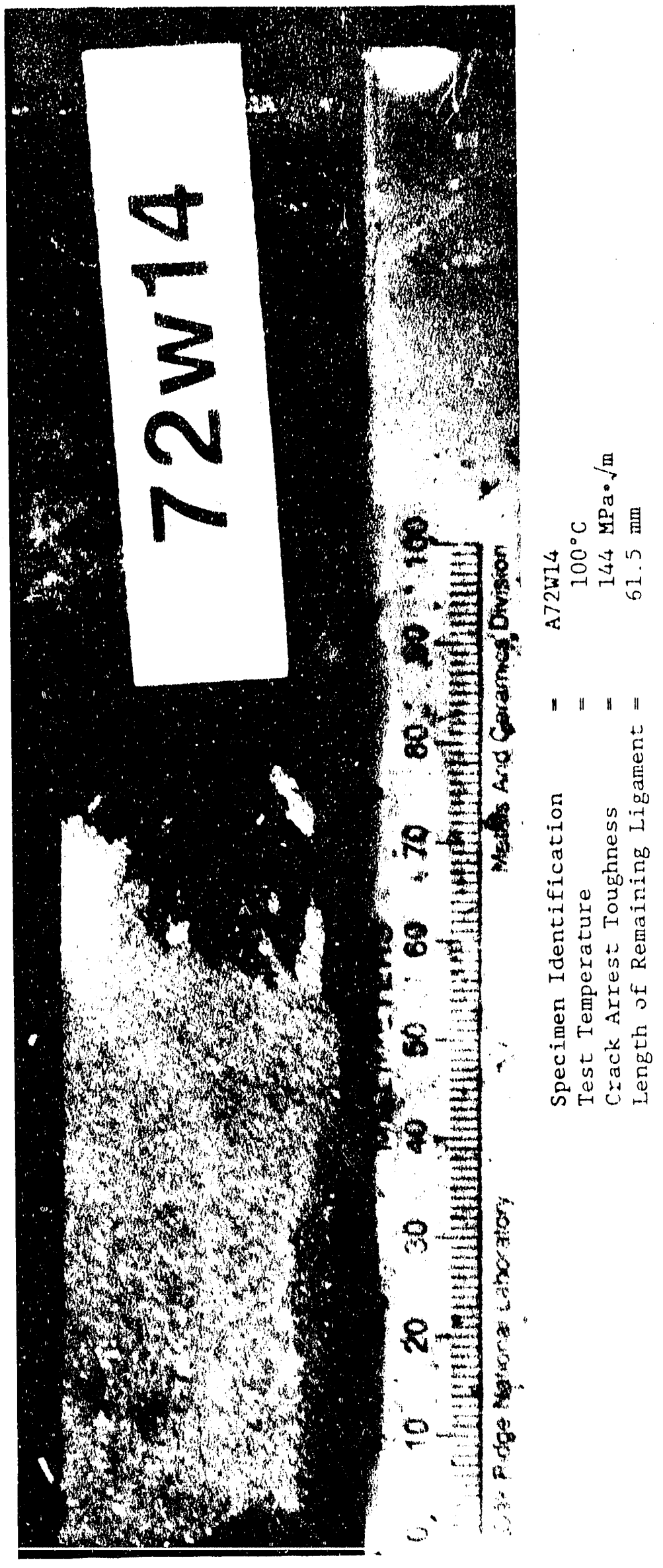




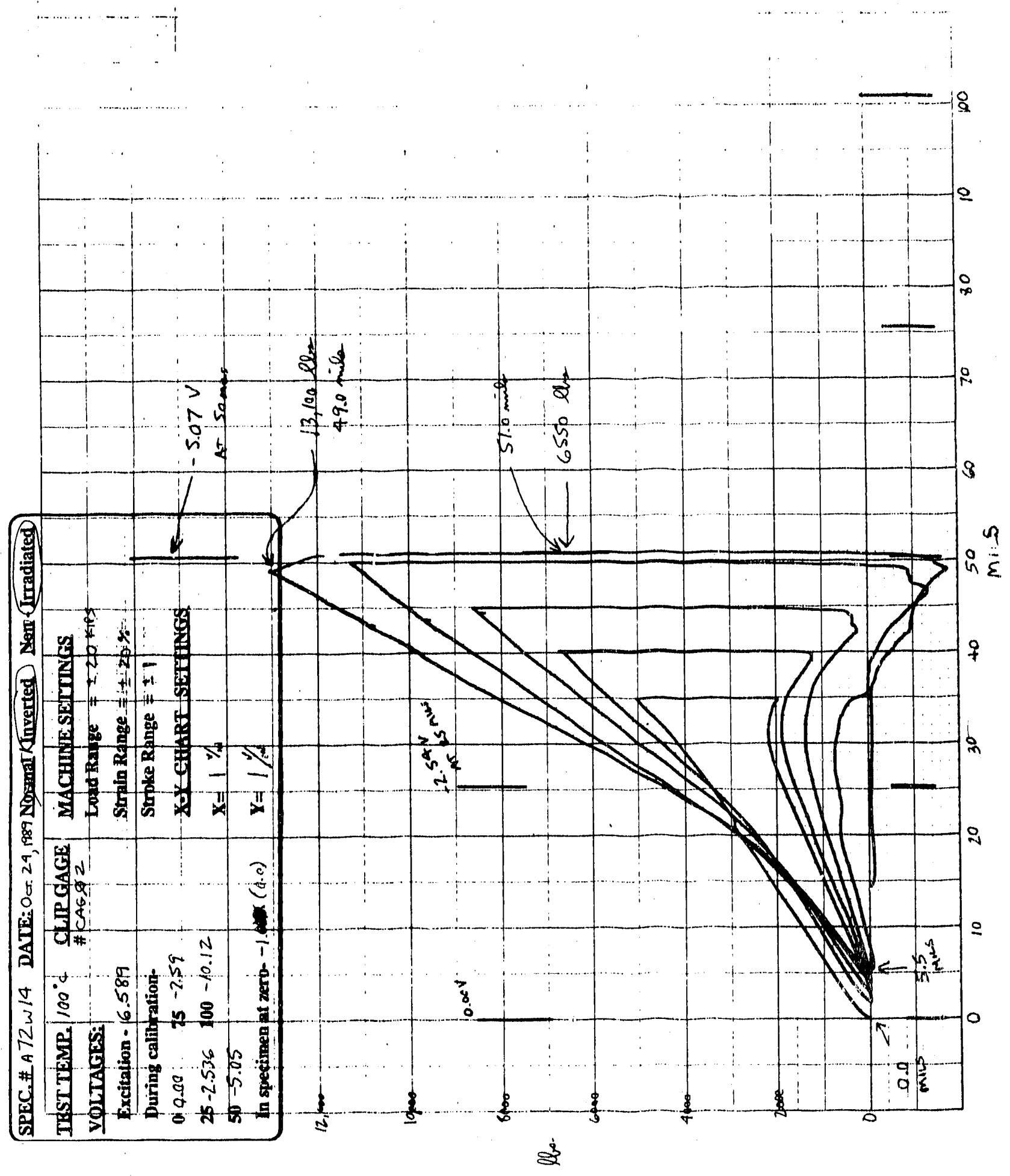




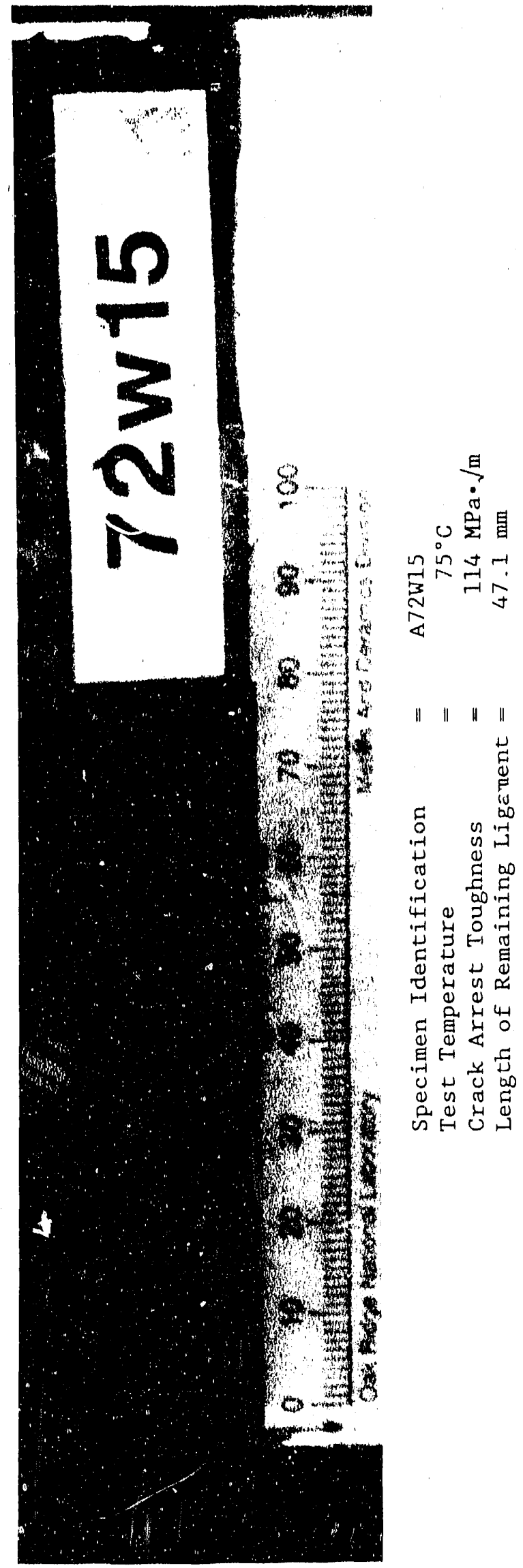



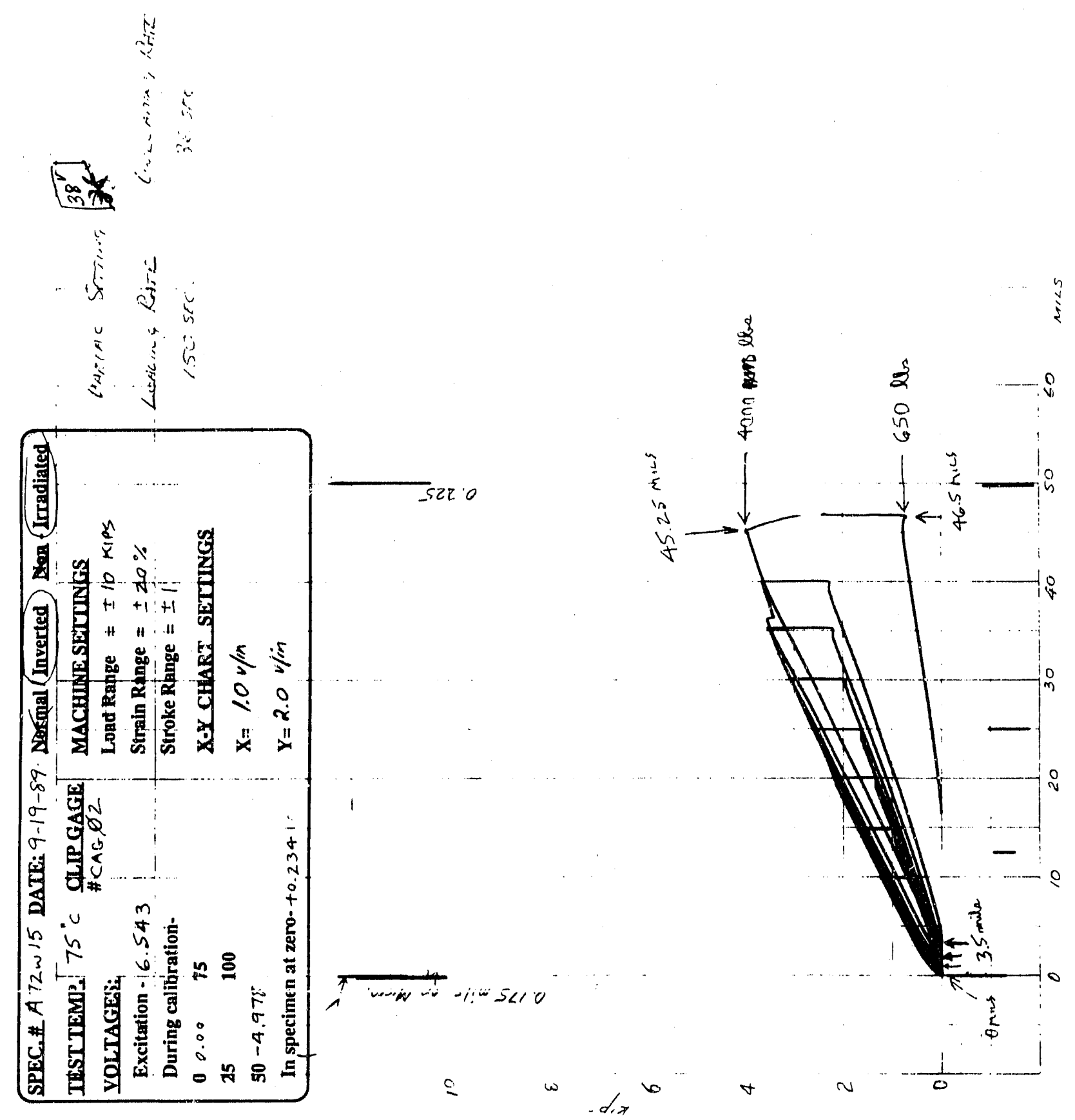


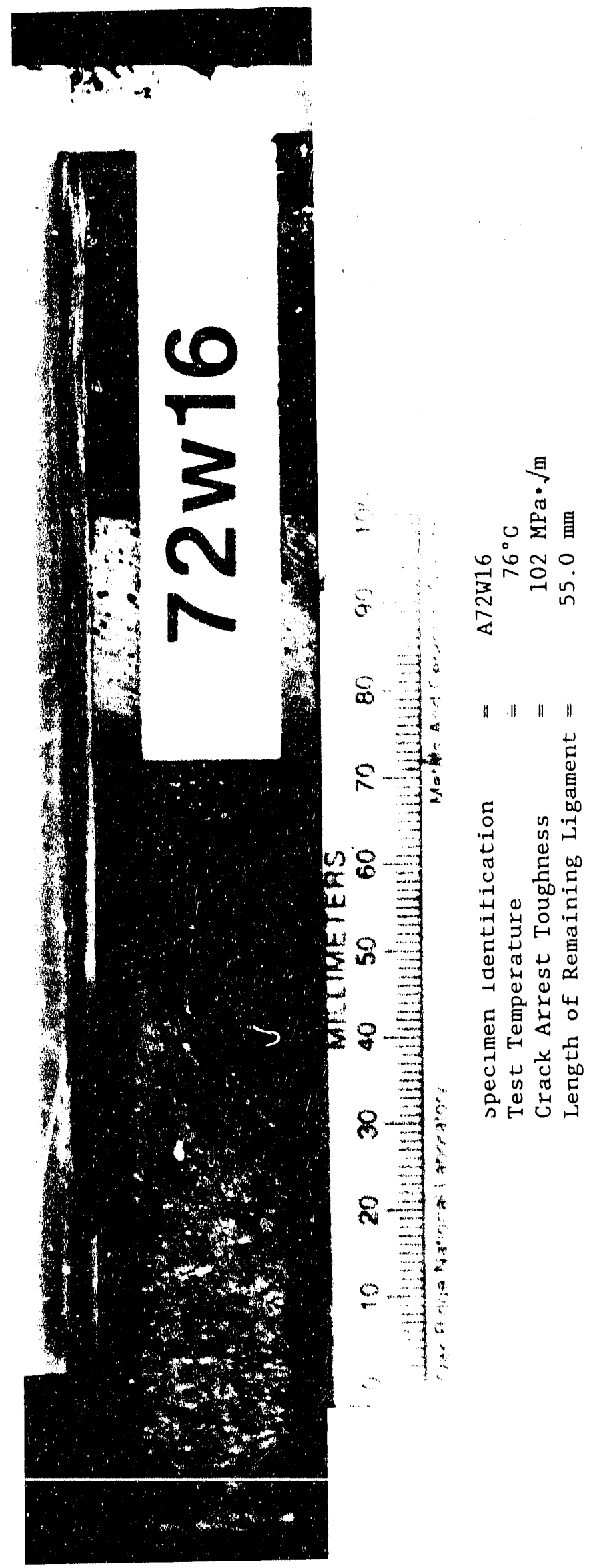




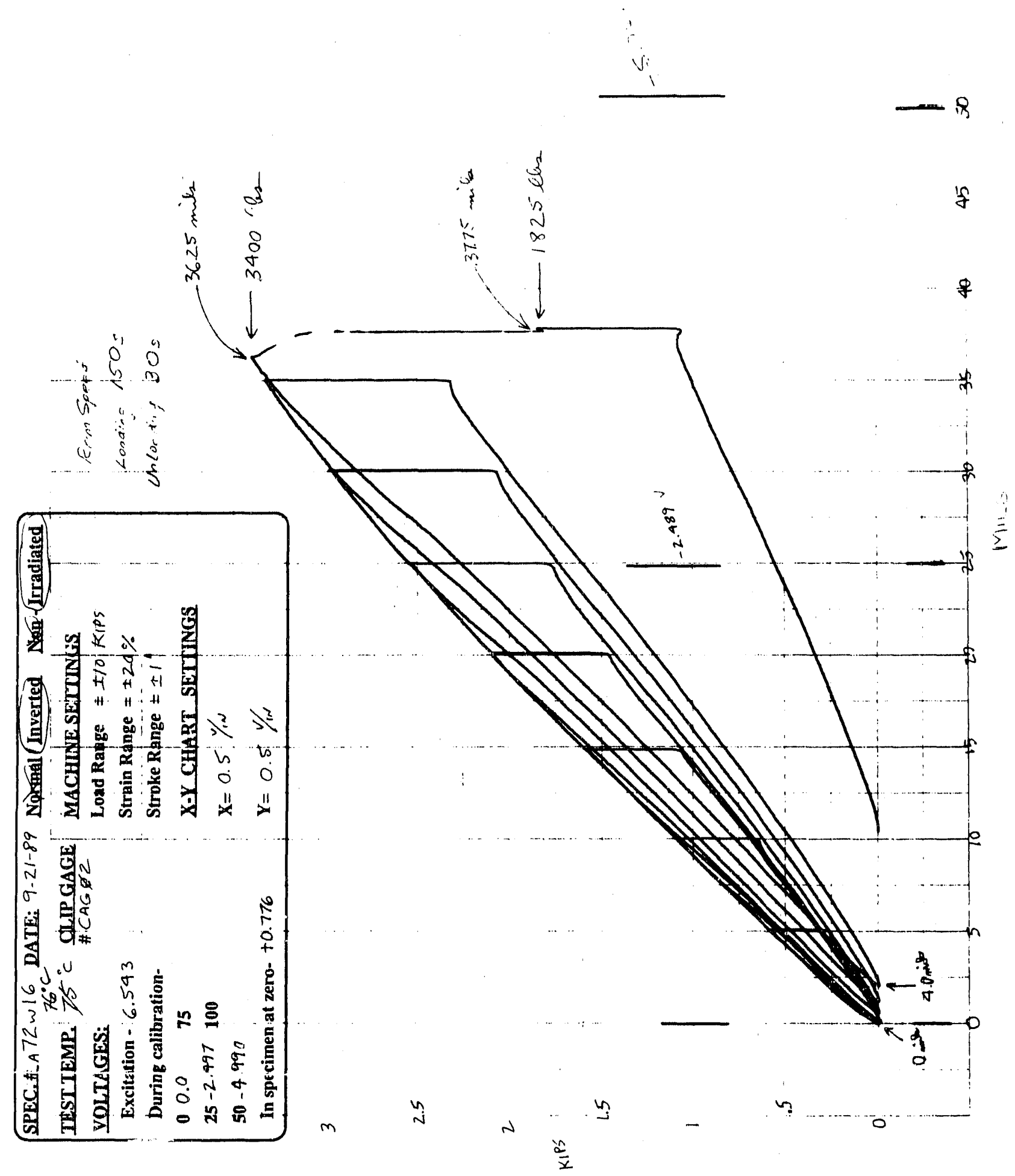




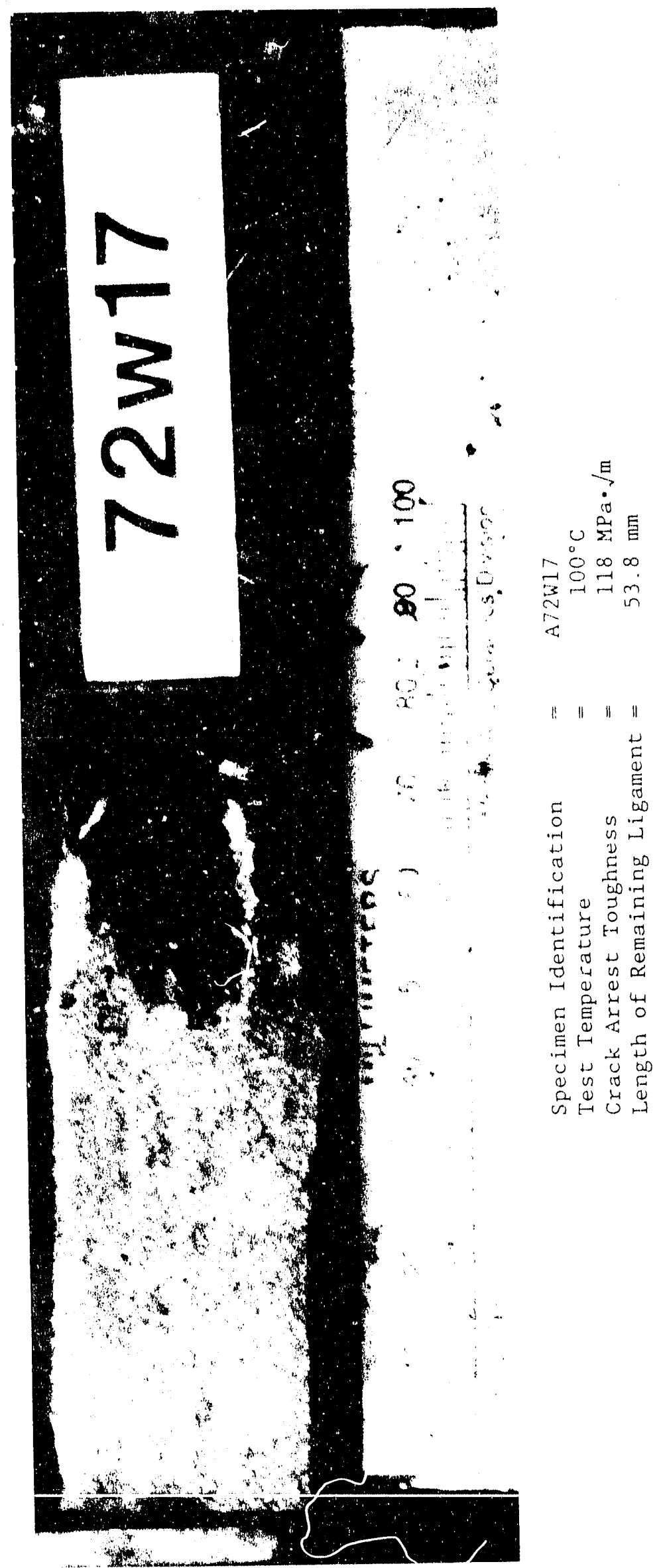



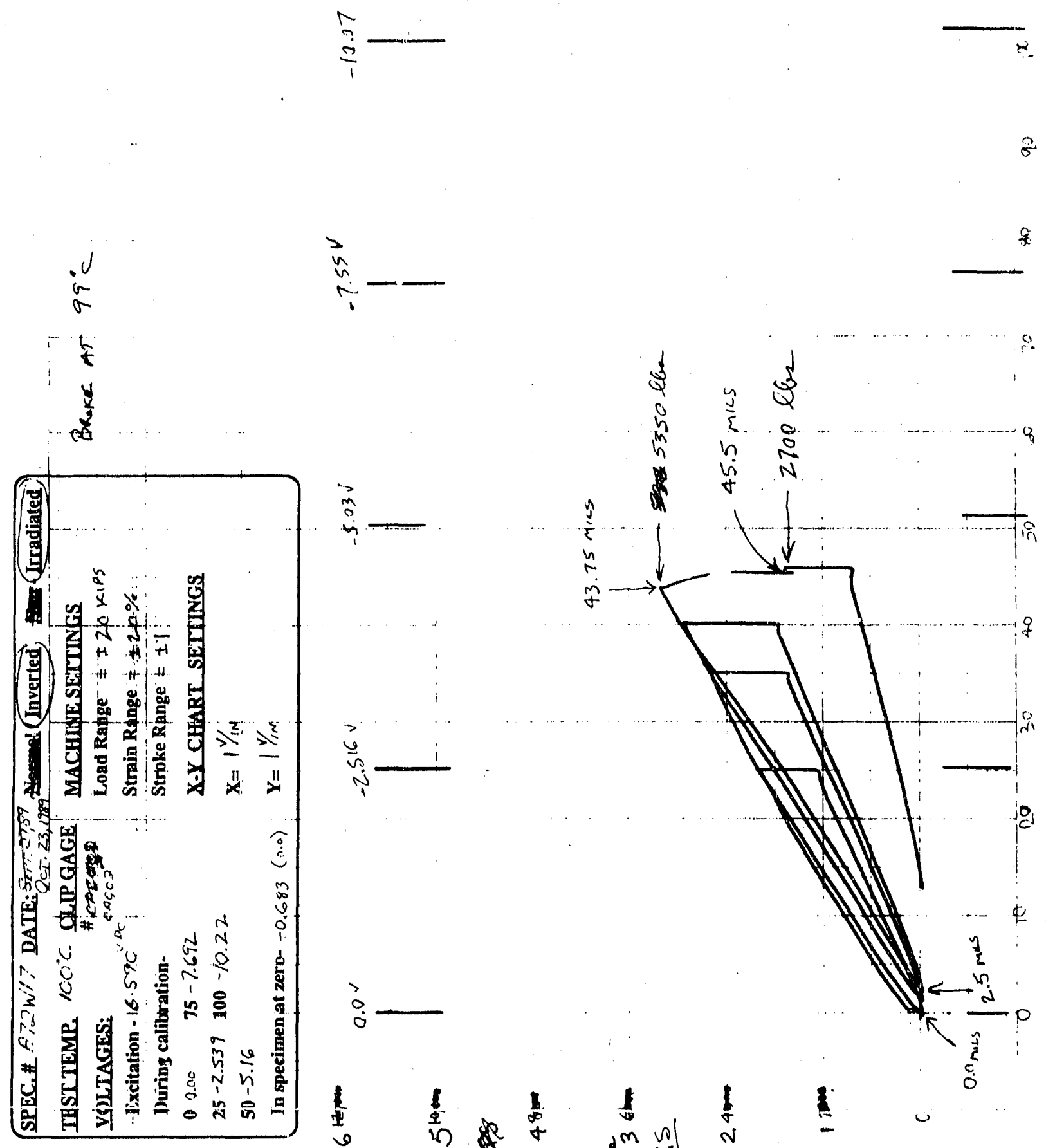

4

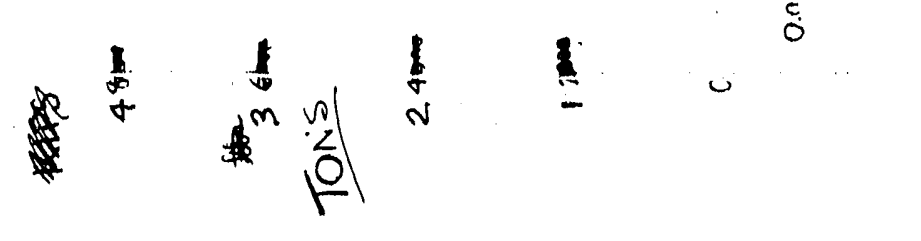




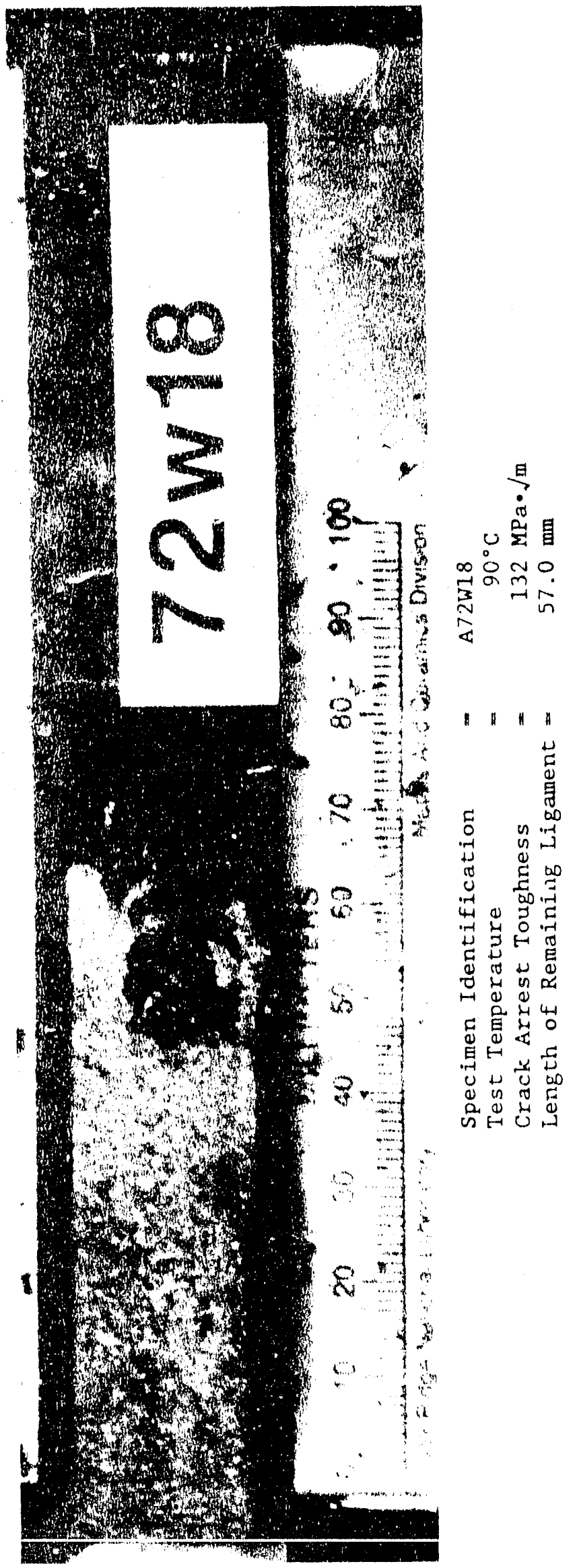



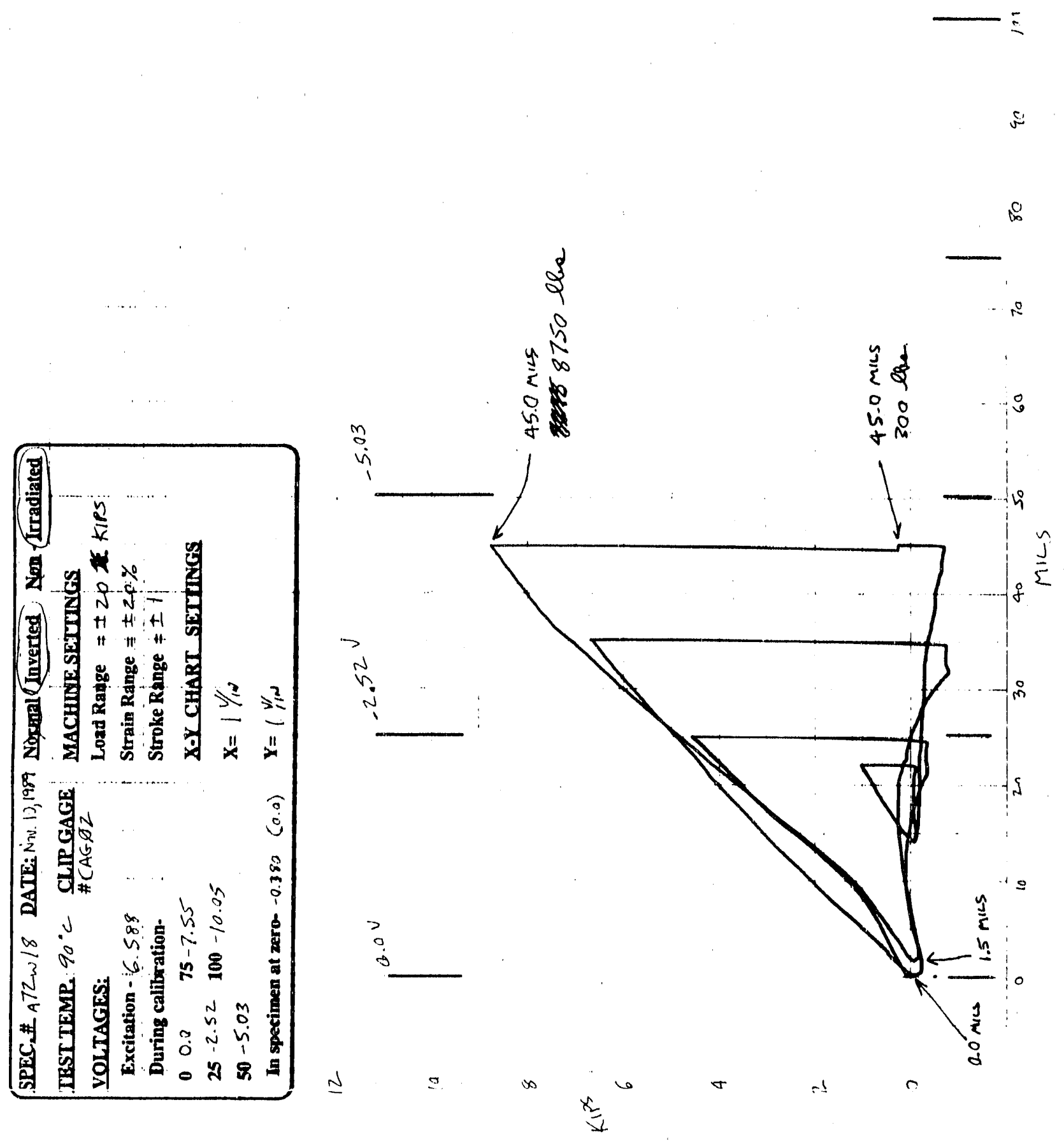


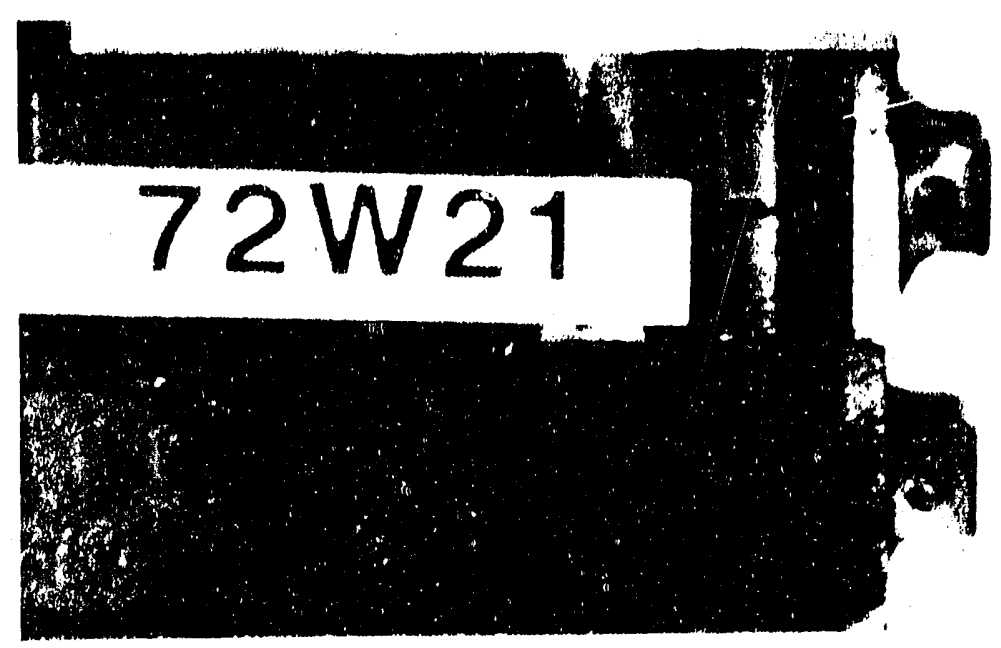

Specimen Jdentification Test lemperature

Crack Arrest Toughnoss

Leng,th of Remaining ligament =
A) 2W21

$30^{\circ} \mathrm{C}$

$53 \mathrm{MPa} \cdot \sqrt{\mathrm{m}}$

$19.9 \mathrm{~mm}$ 

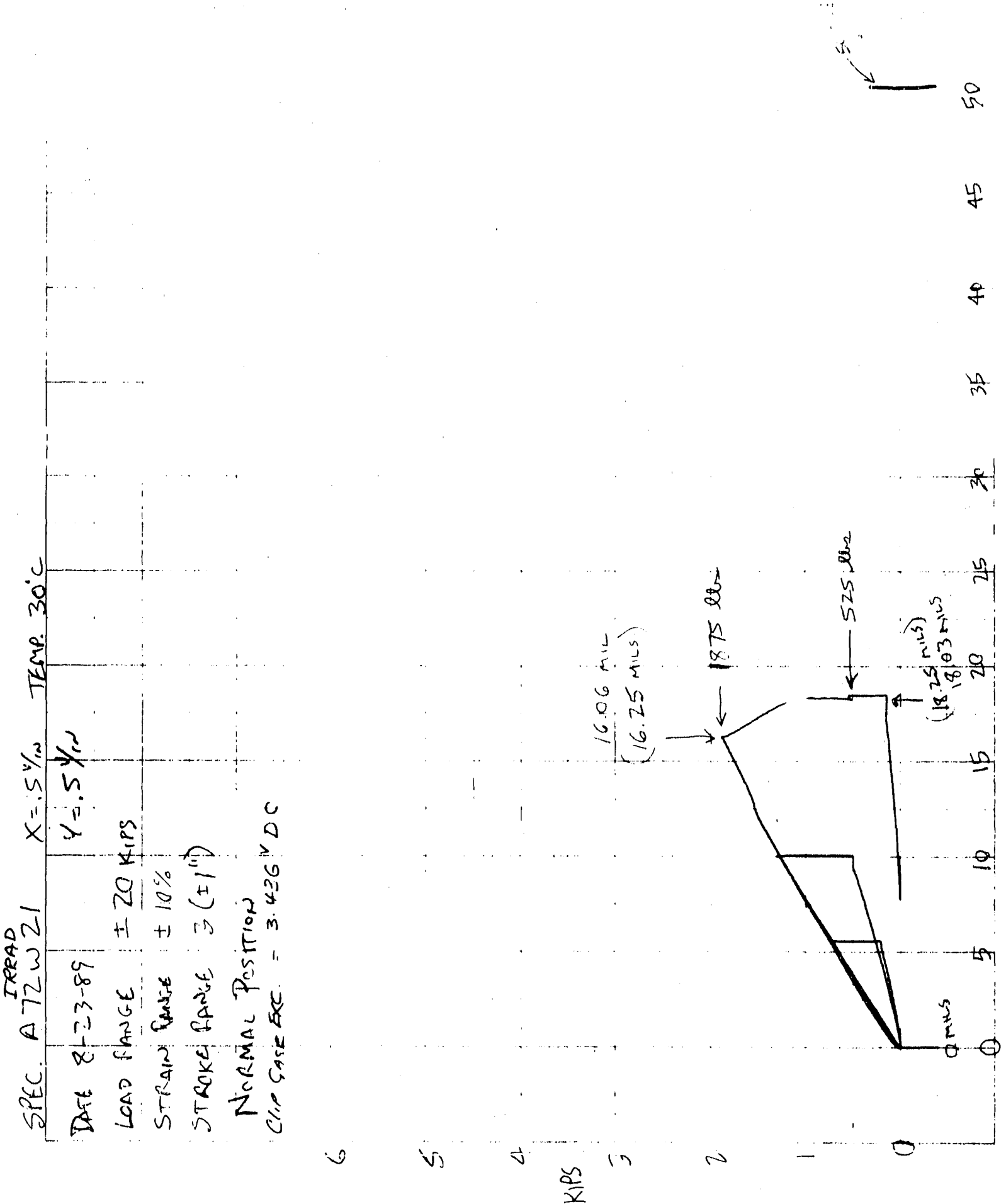


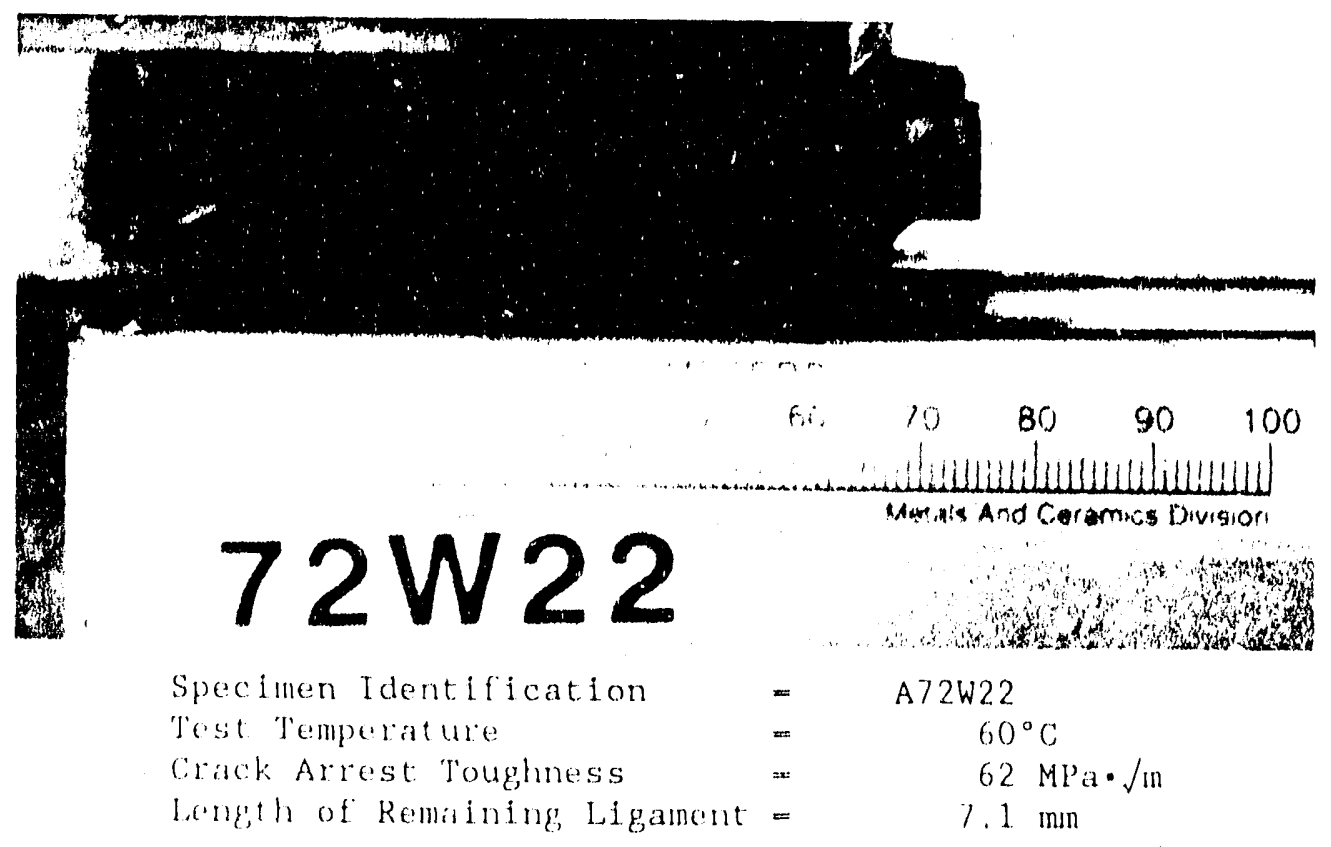



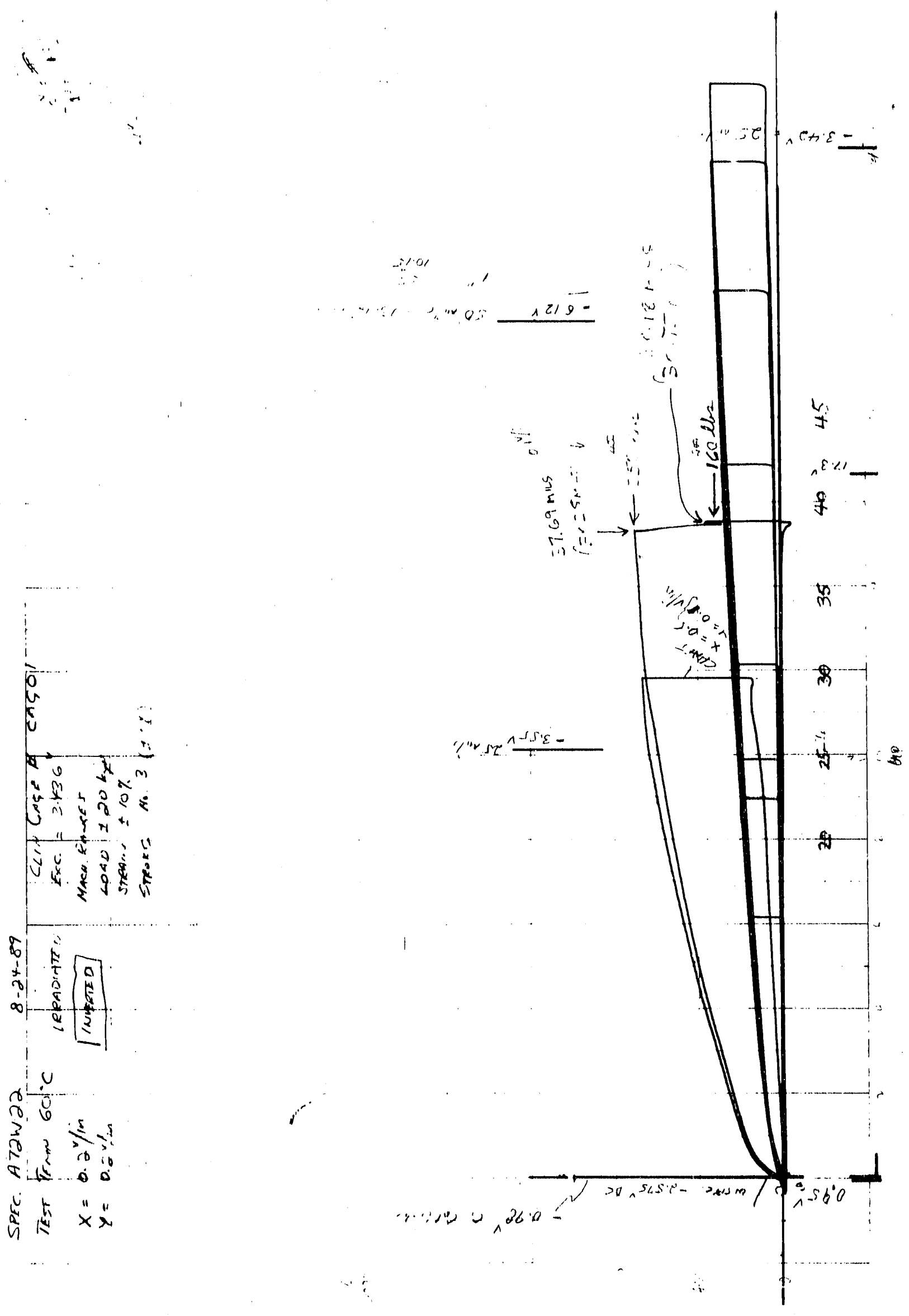


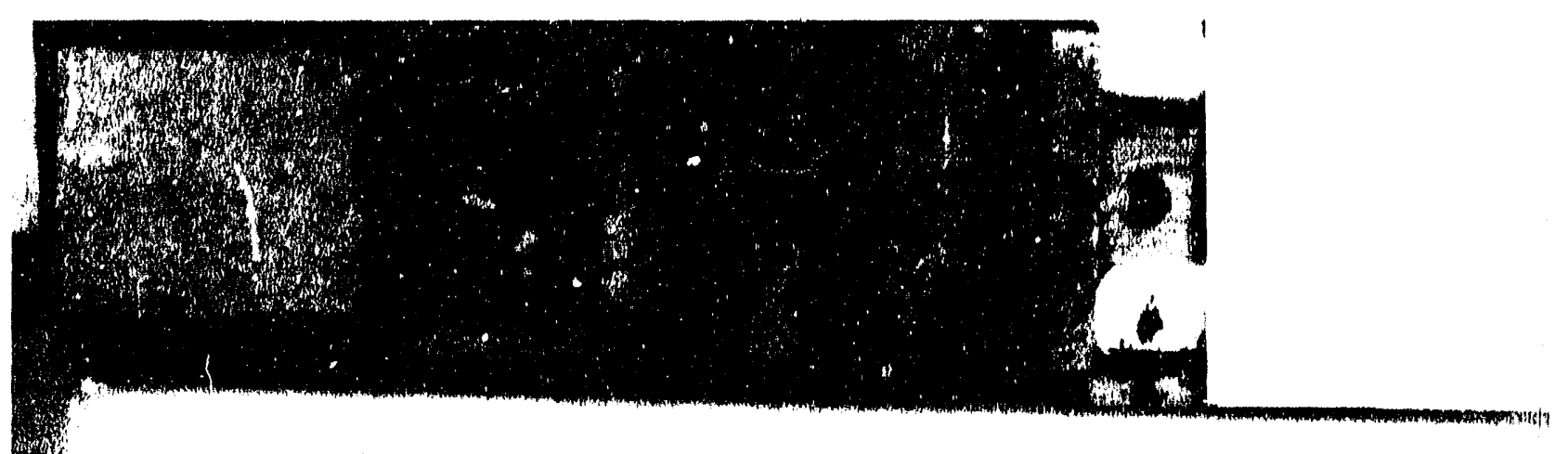

$72 W 23$
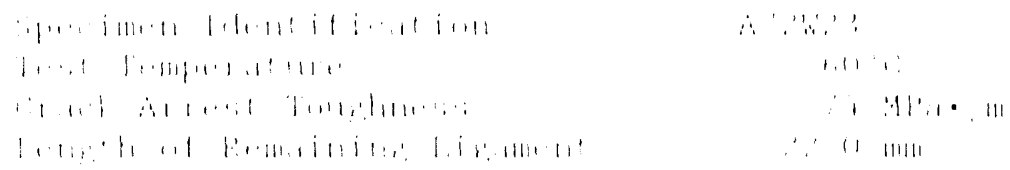


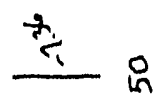

$+$

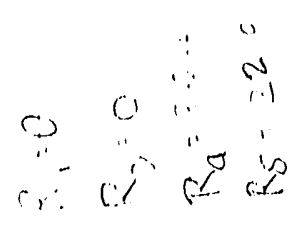

q

$m$

i
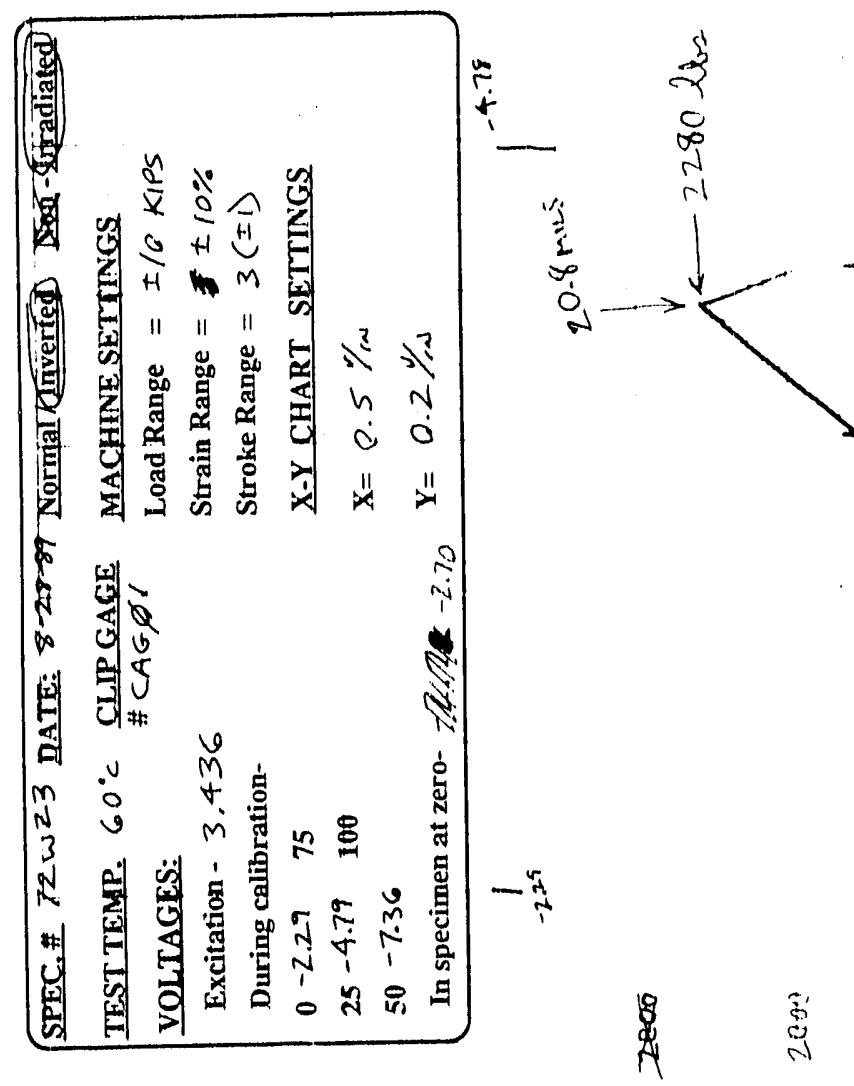


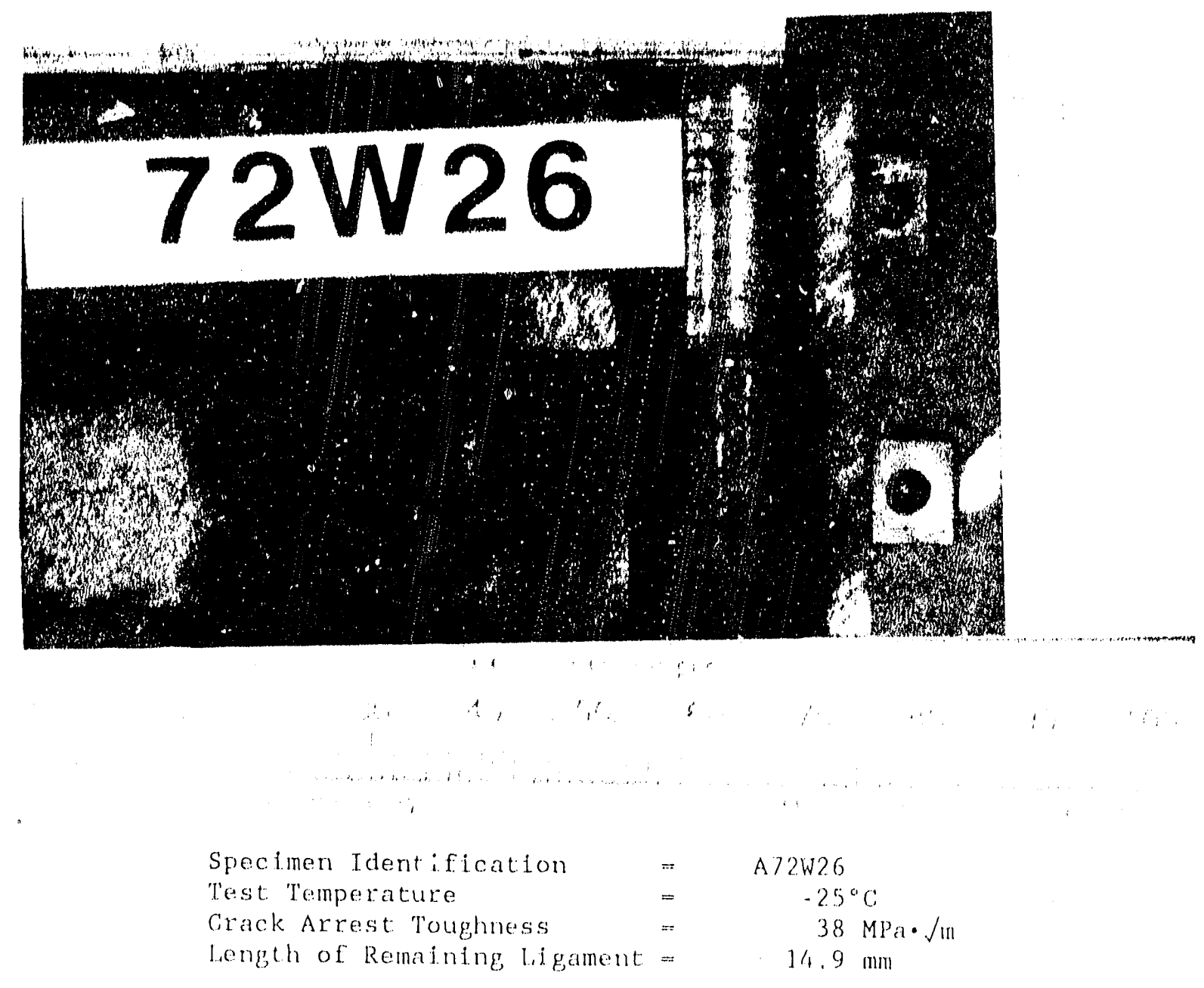




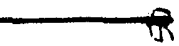

f.

q

है:
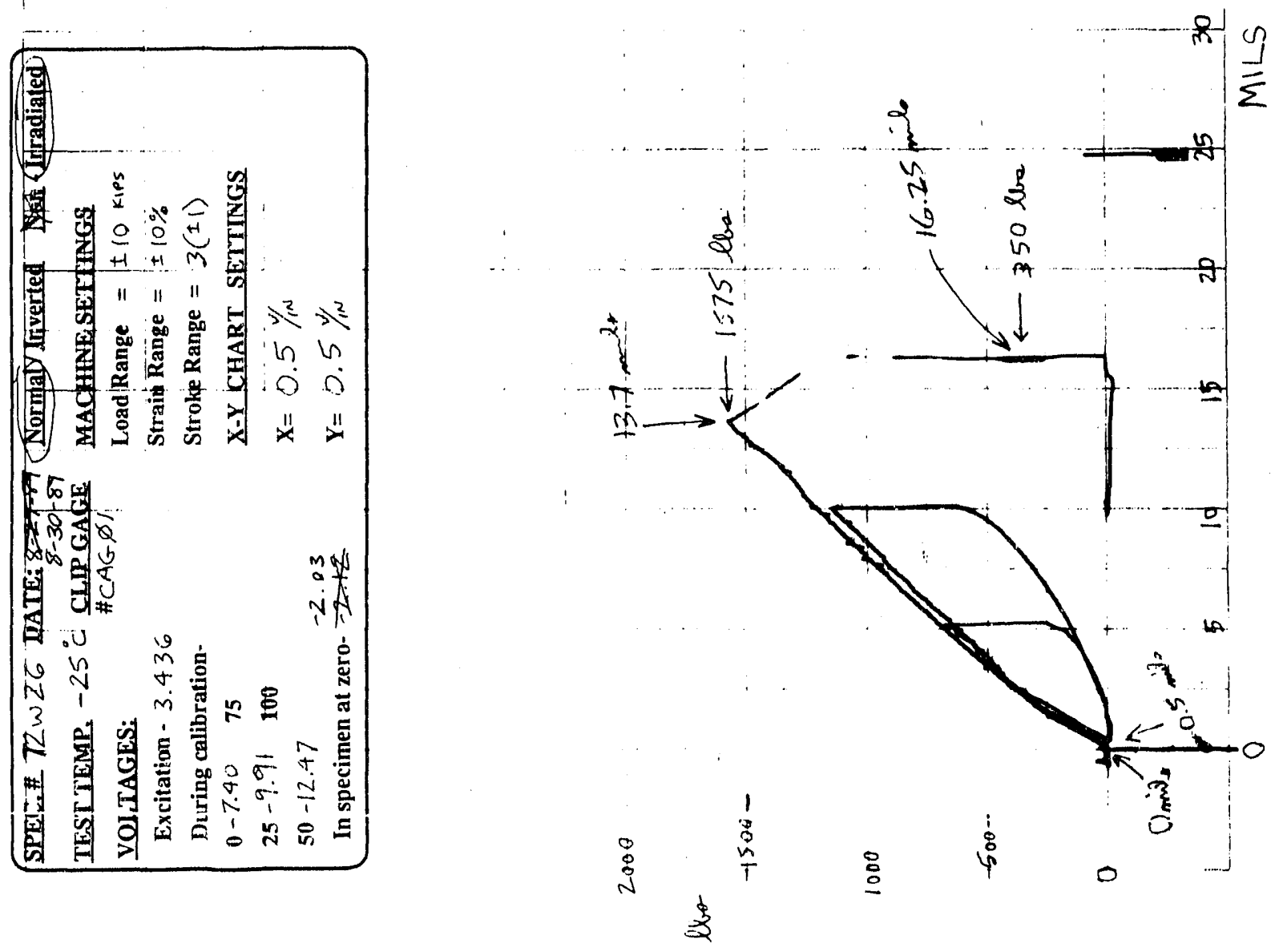


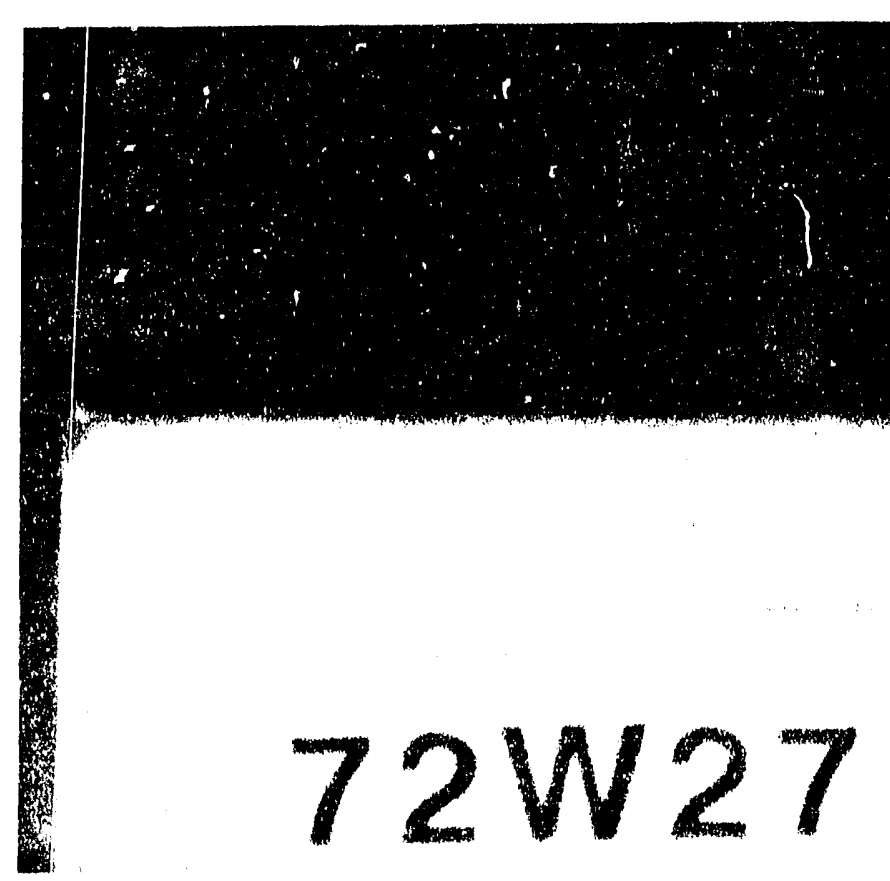

Specimen Ident if icat jon Tesst Temperature

Crack Arrest Toughness:

leng,th of Remaining, Ligrament

Al:W?

$\because 3 " \mathrm{C}$

6) $\mathrm{MH}^{\mathrm{i}} \cdot \sqrt{\mathrm{III}}$

18.3 mant 


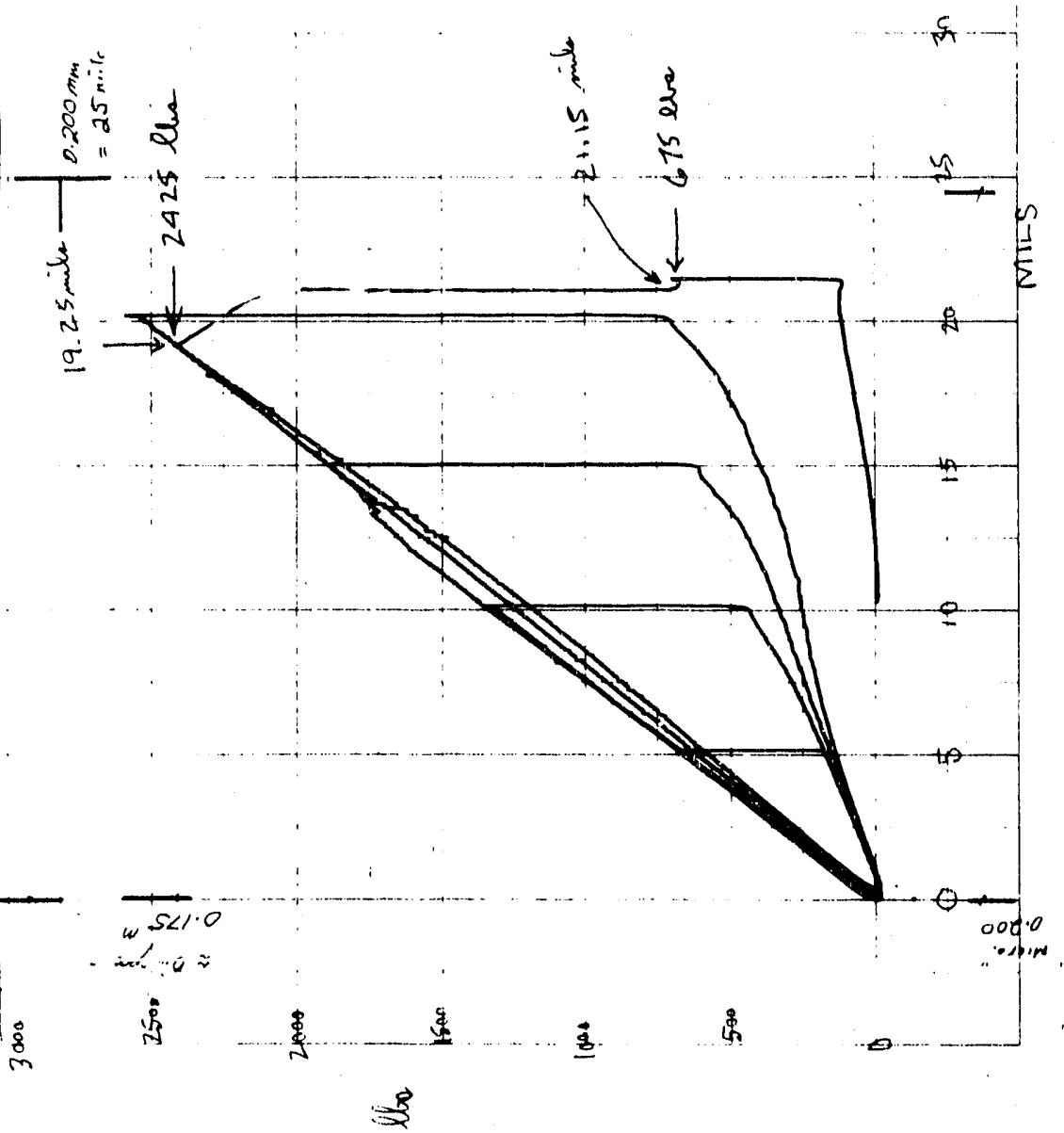




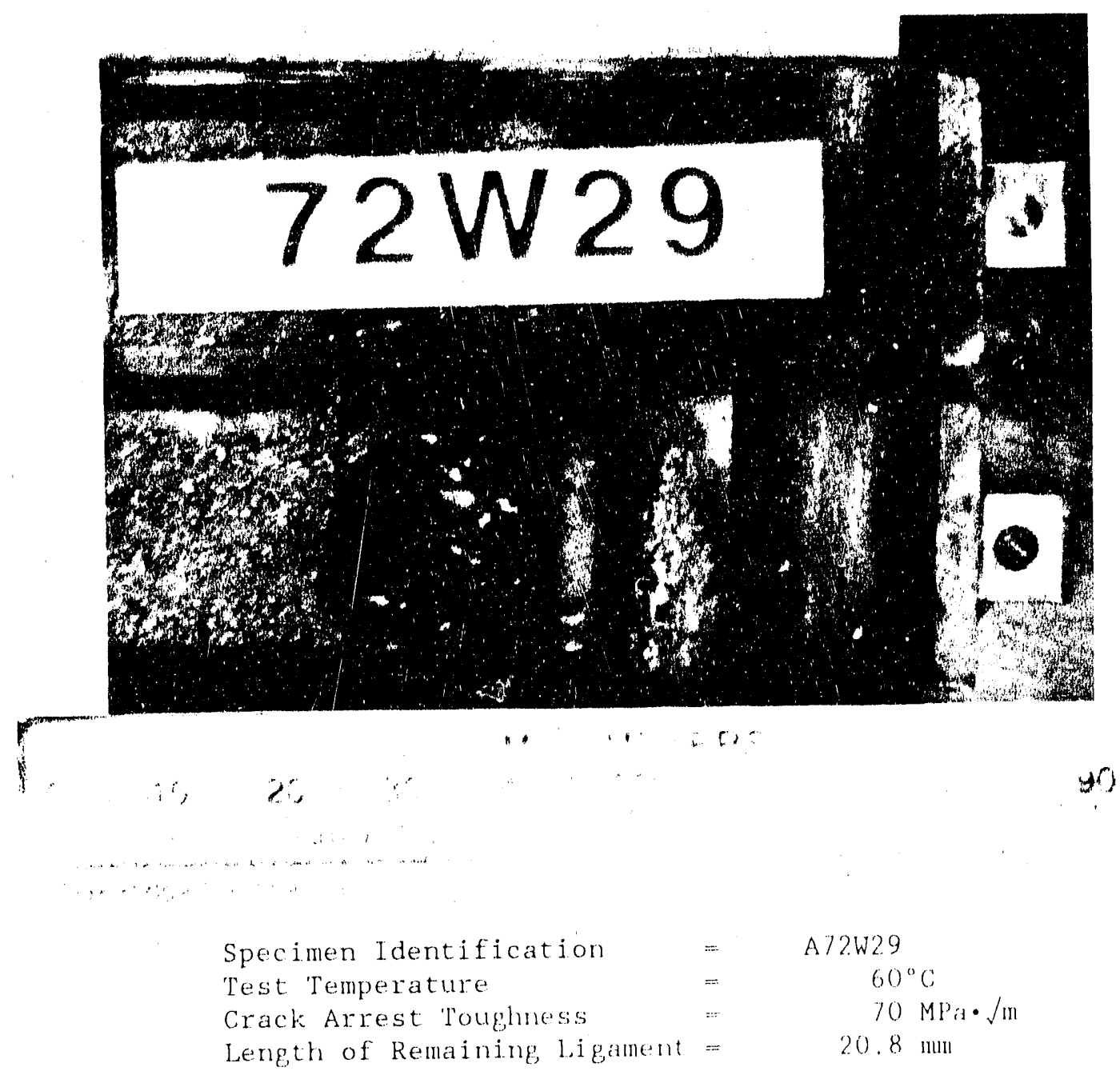


-

$\lg$

ㄱำ

$\frac{w}{m}$

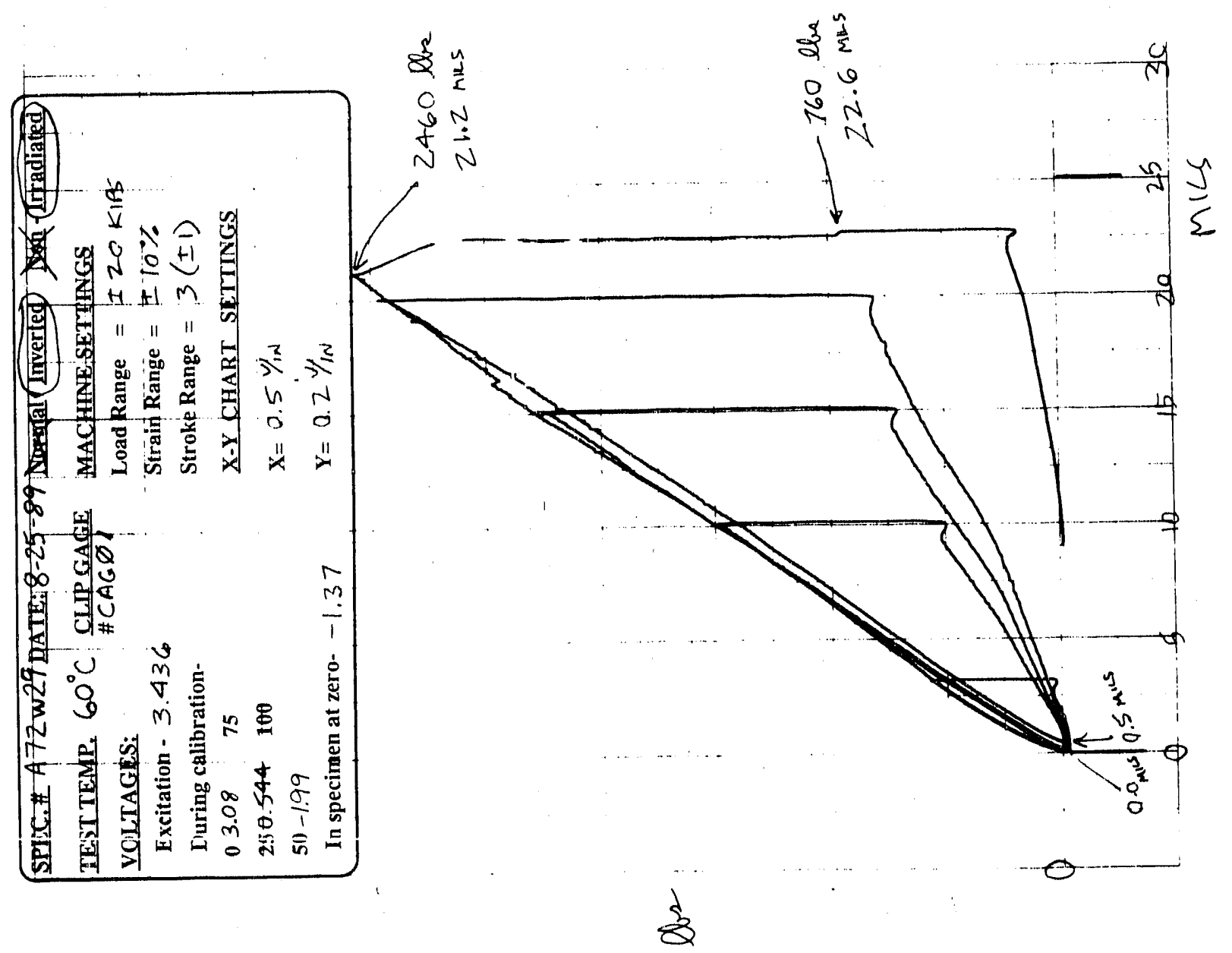




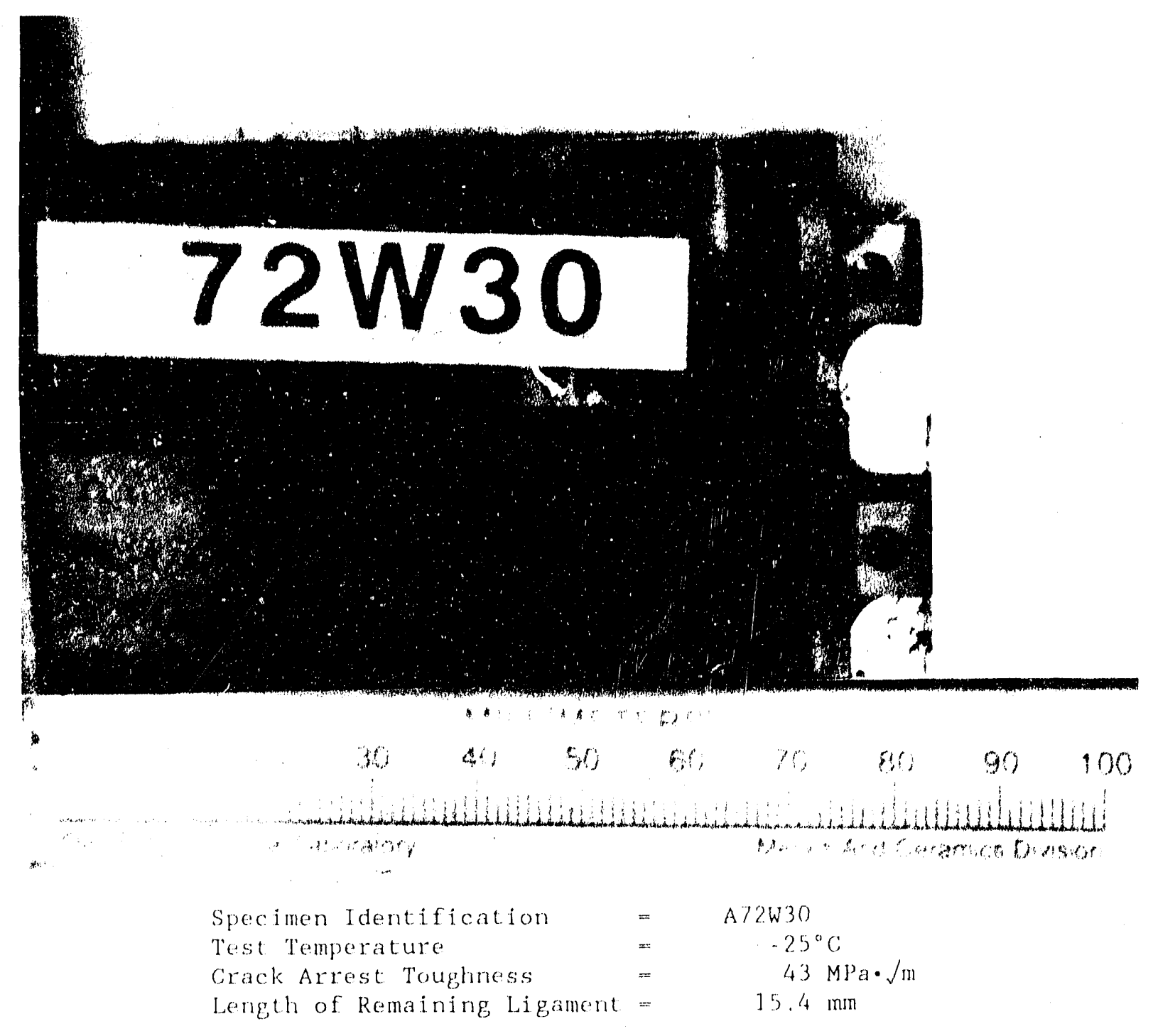



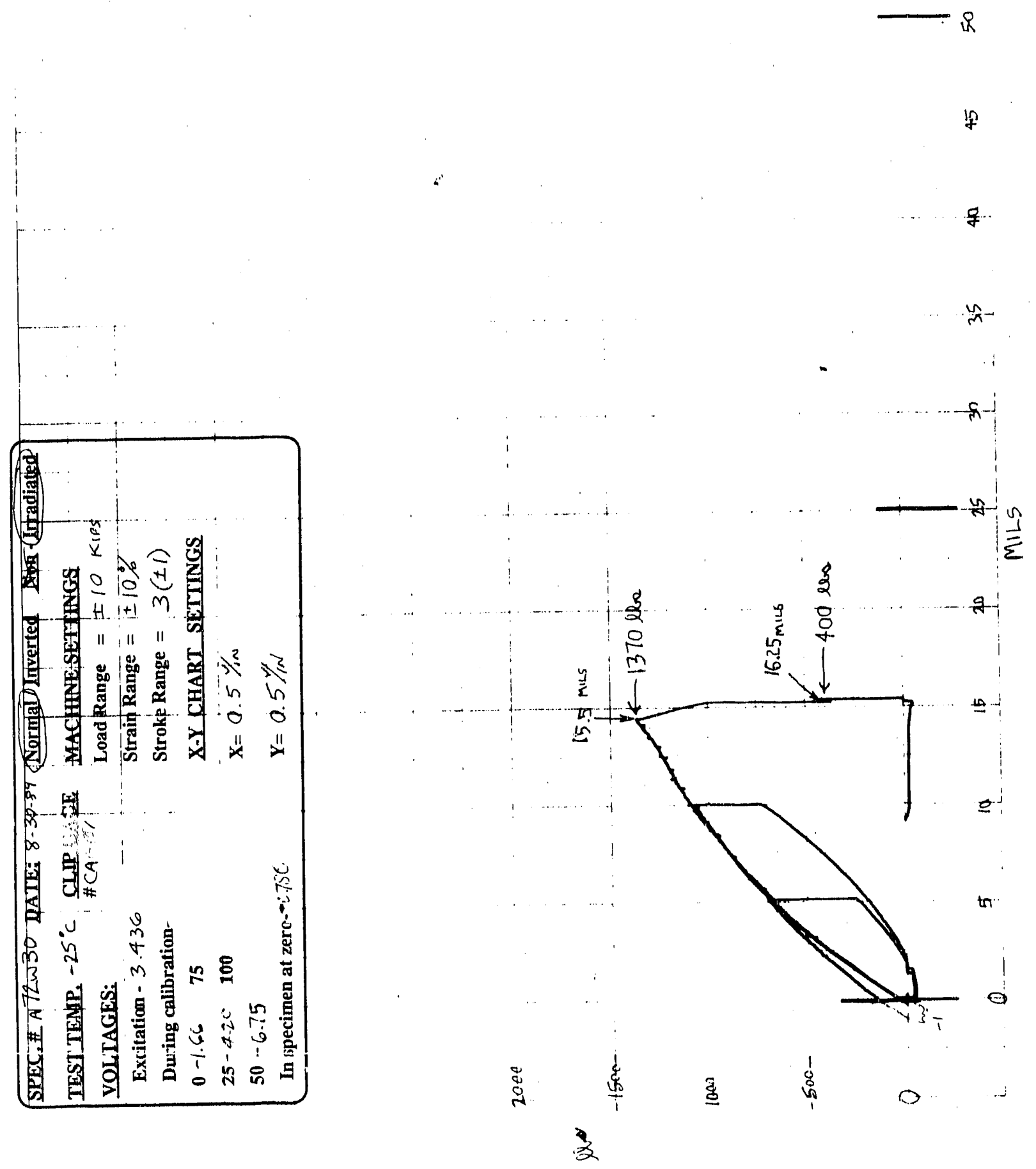


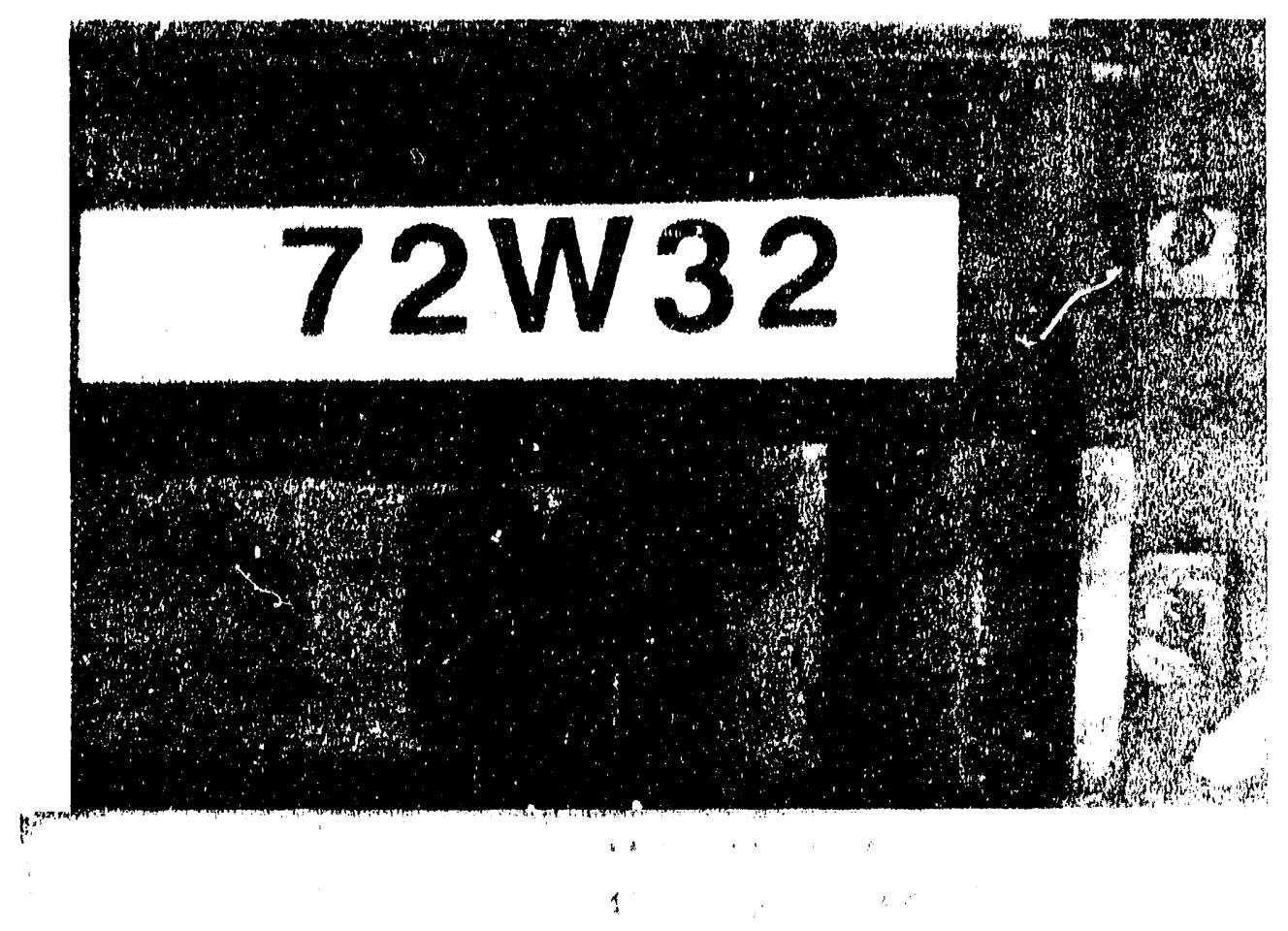

Specimen Identification 'Test 'Temperature

Crack Arrest Toughness

Length of Remaining ligament :
Al? W3?

$3 ? " \mathrm{l}$

(6) $\mathrm{MH}$ (1) / H

?a. \& 


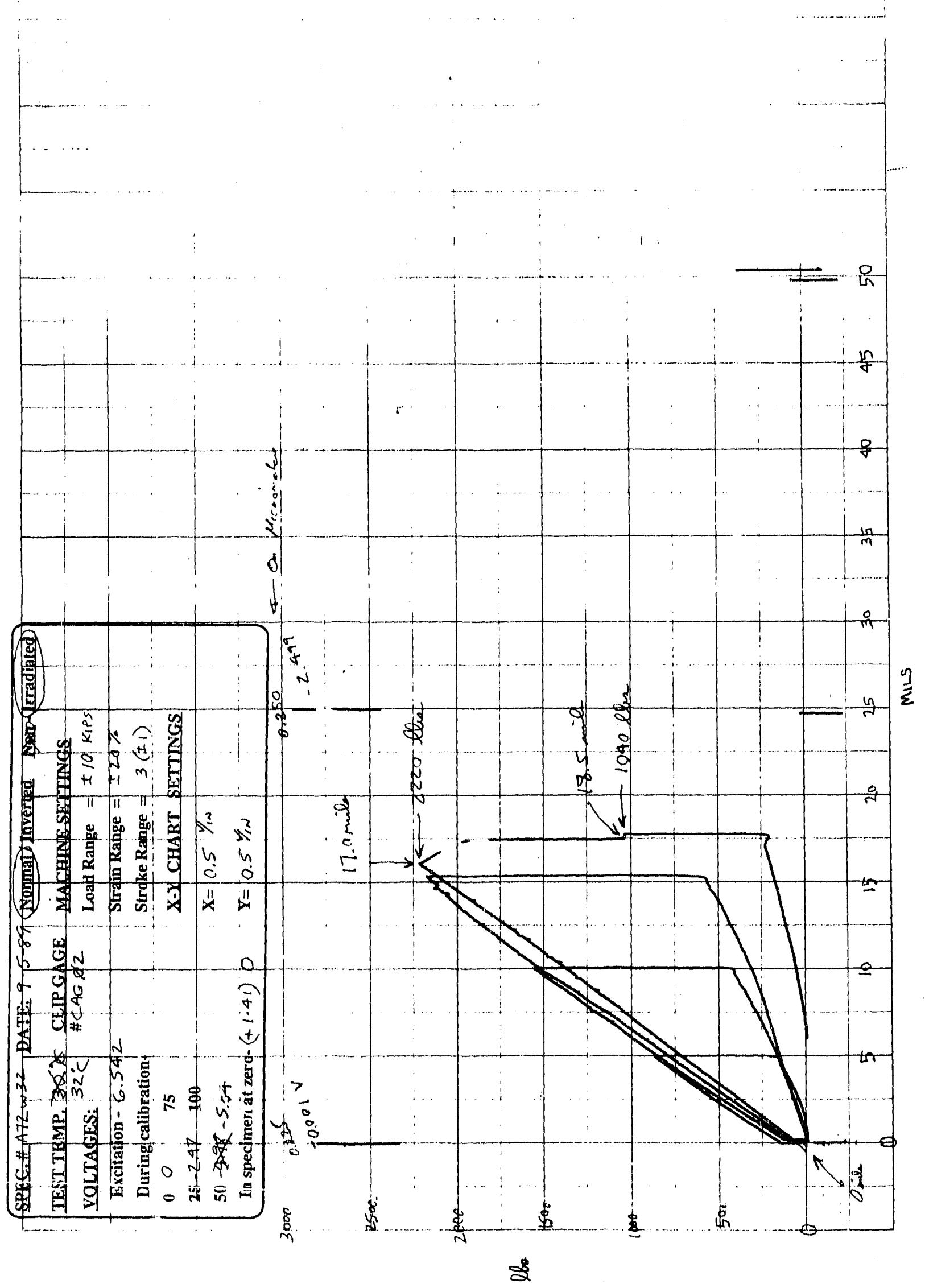




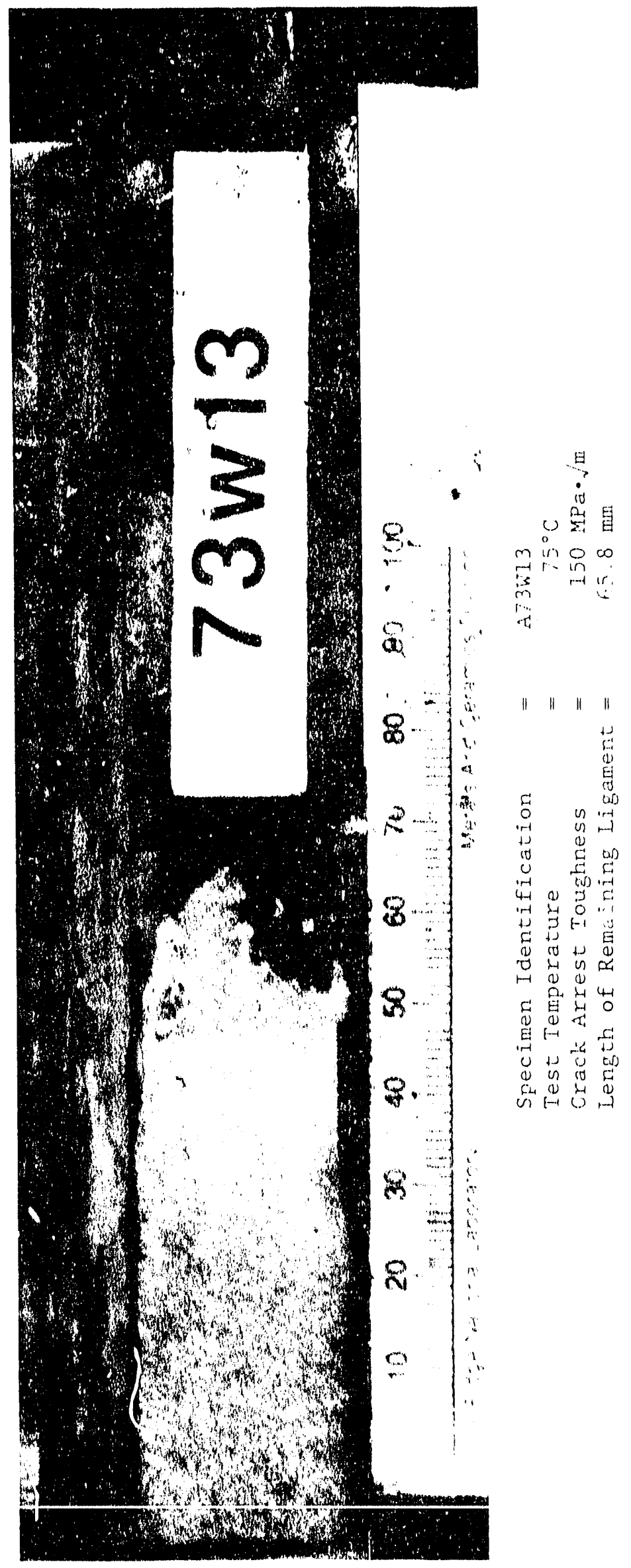




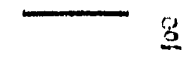
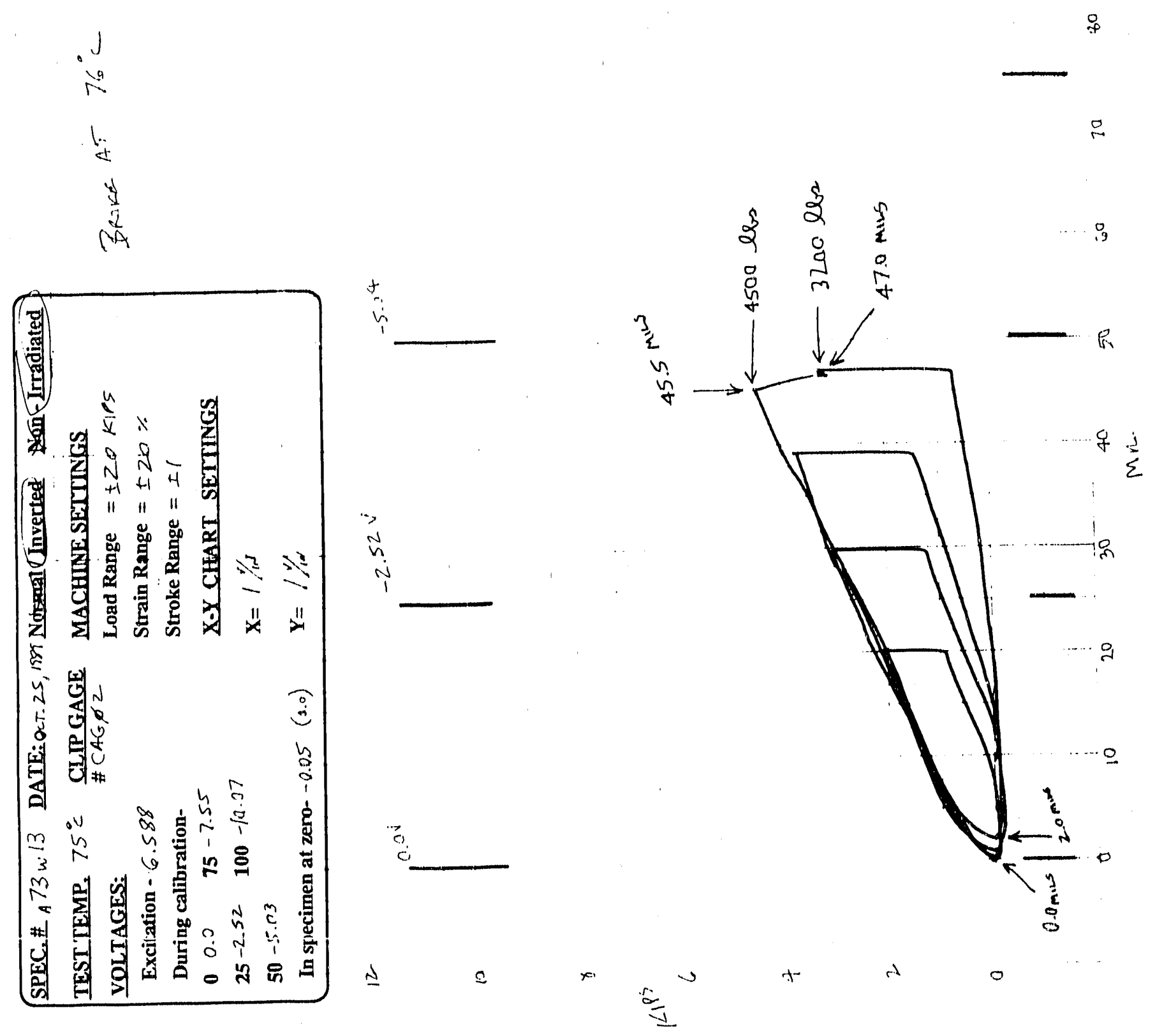

$\pm \quad 0$ 


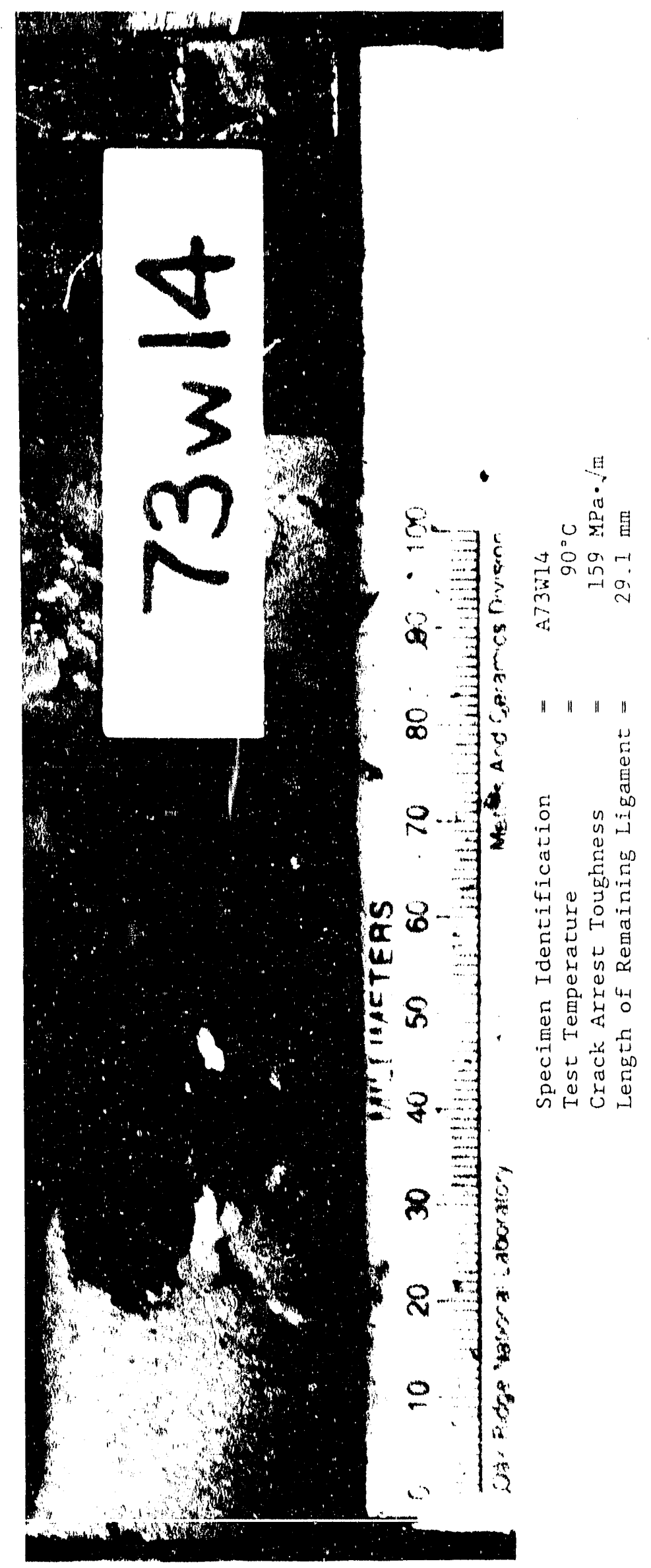




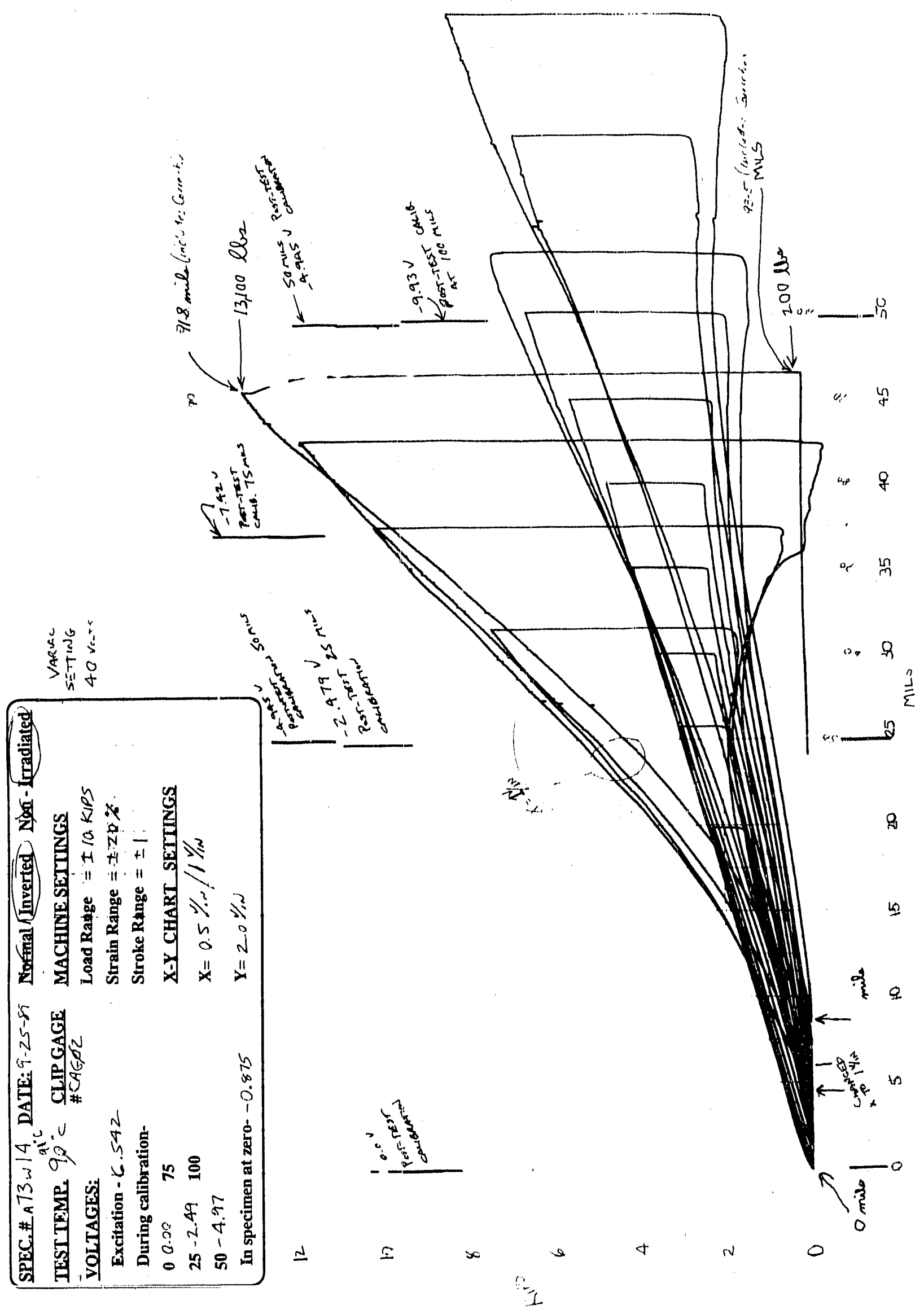



7

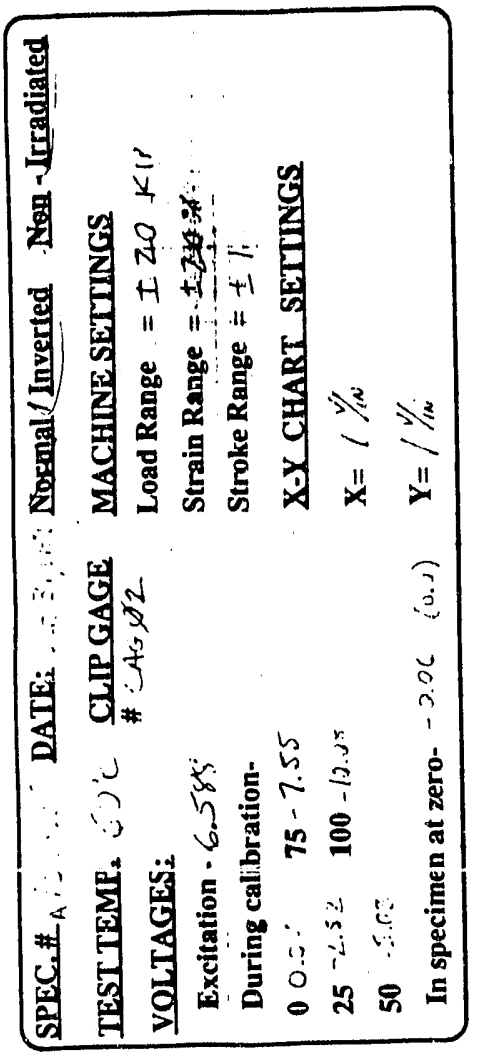<smiles>[Li]</smiles>
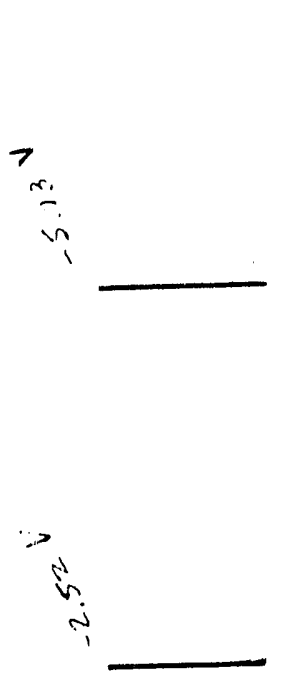


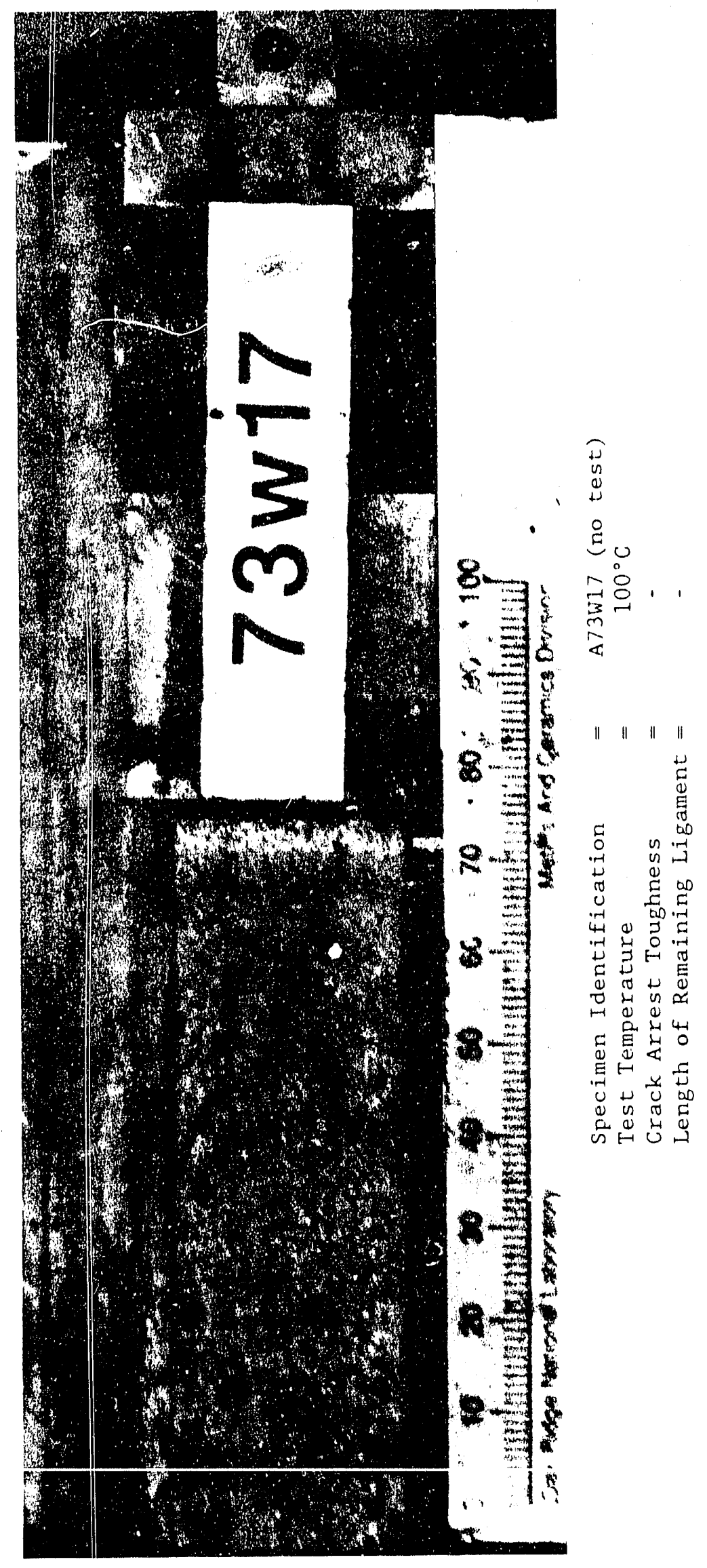




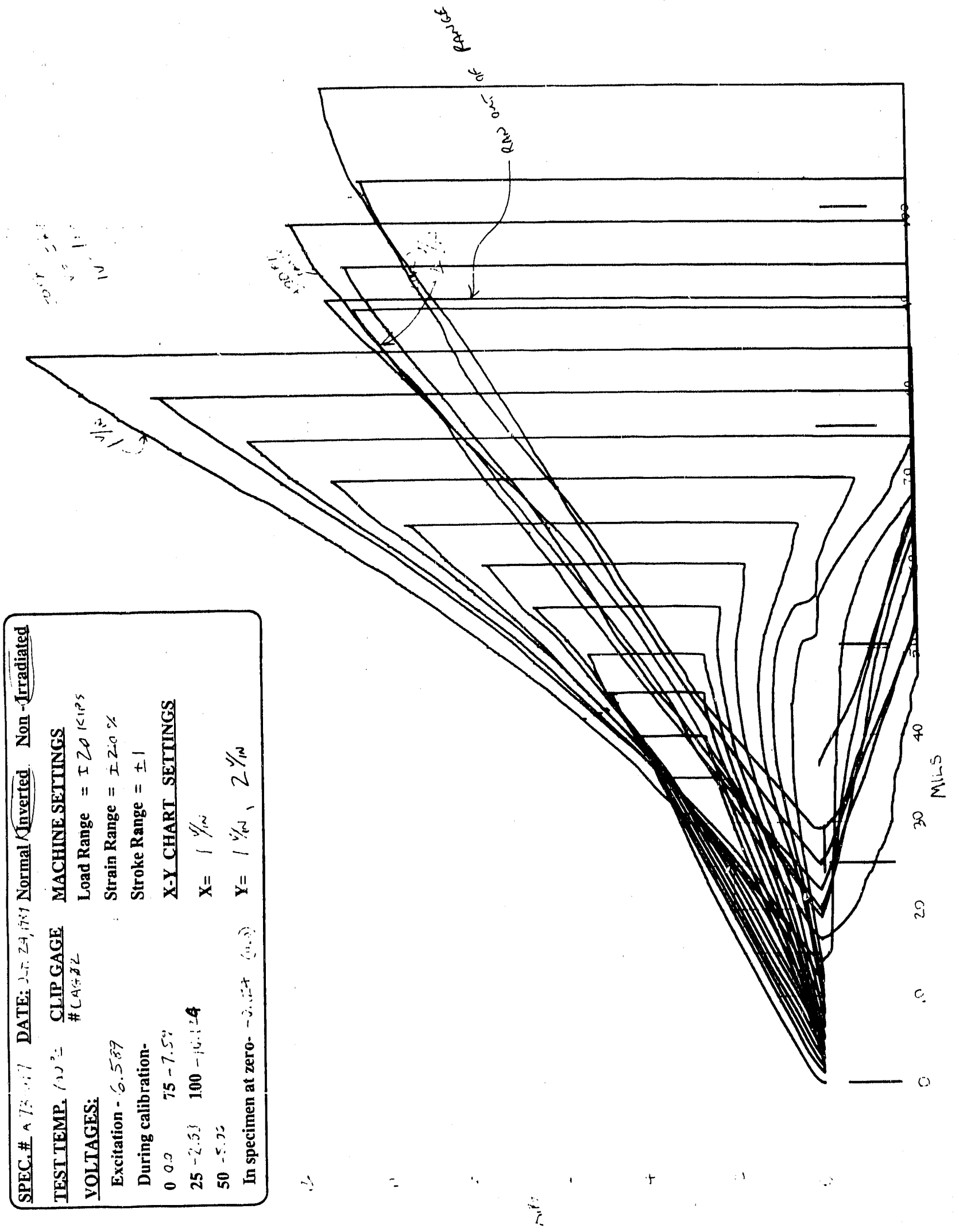




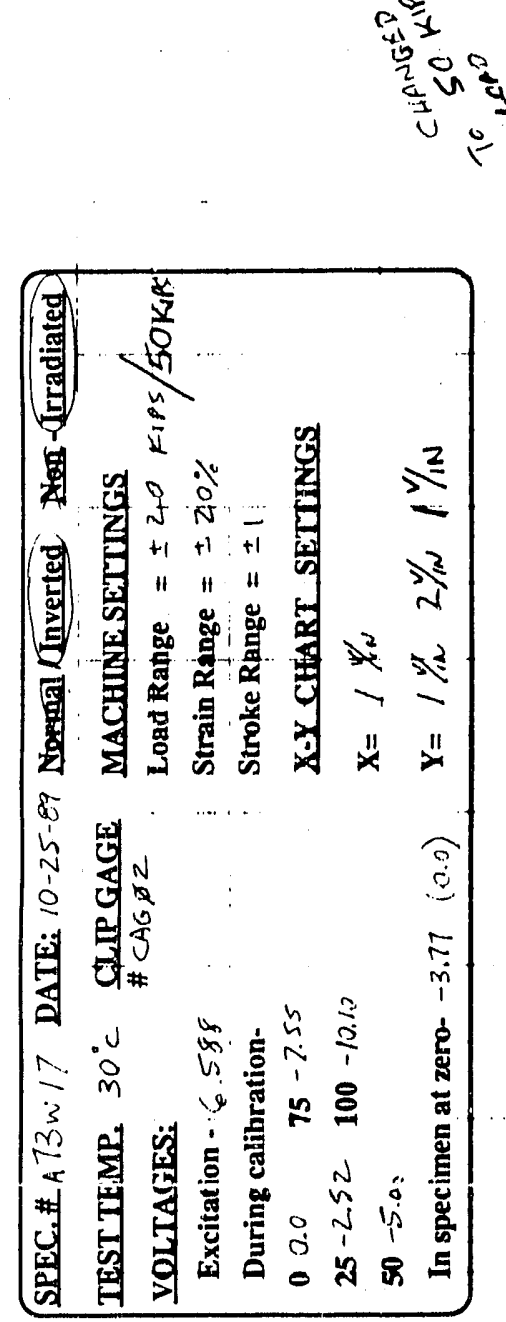

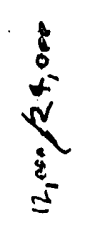
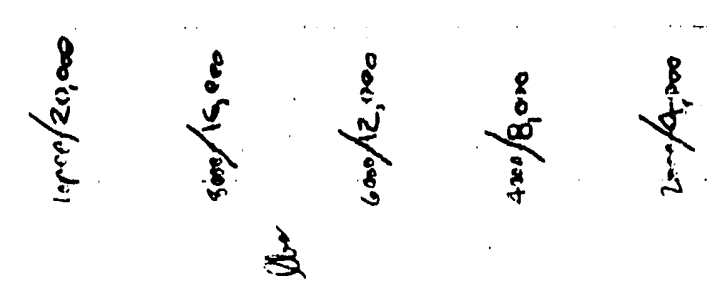


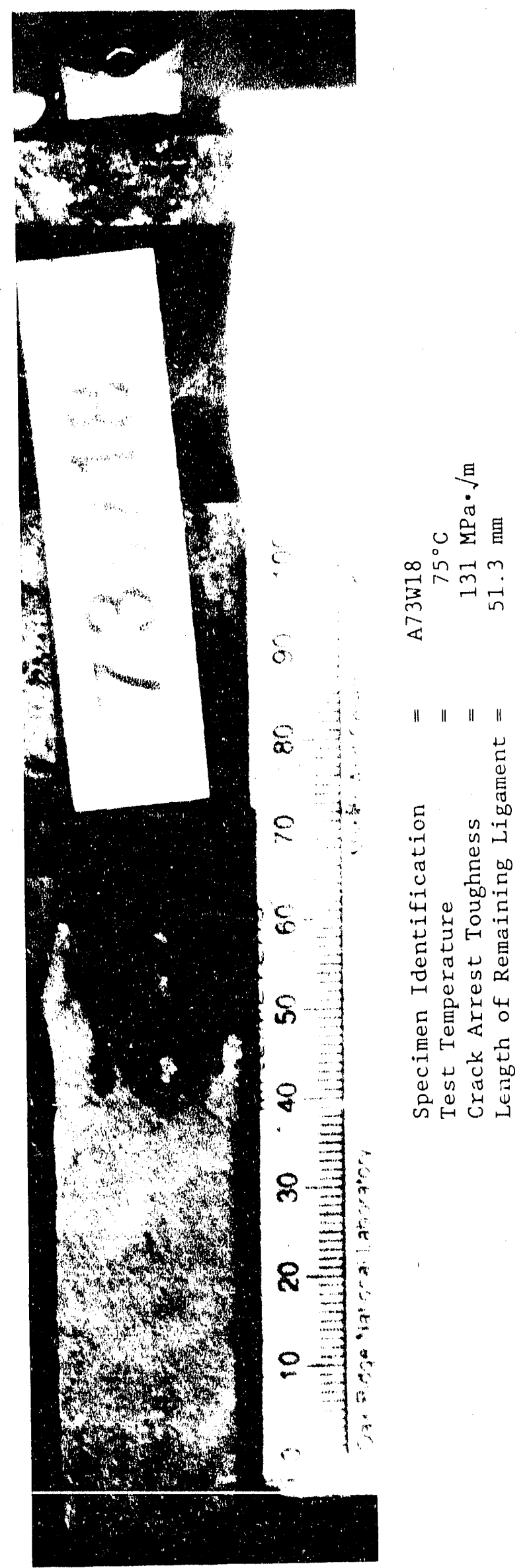




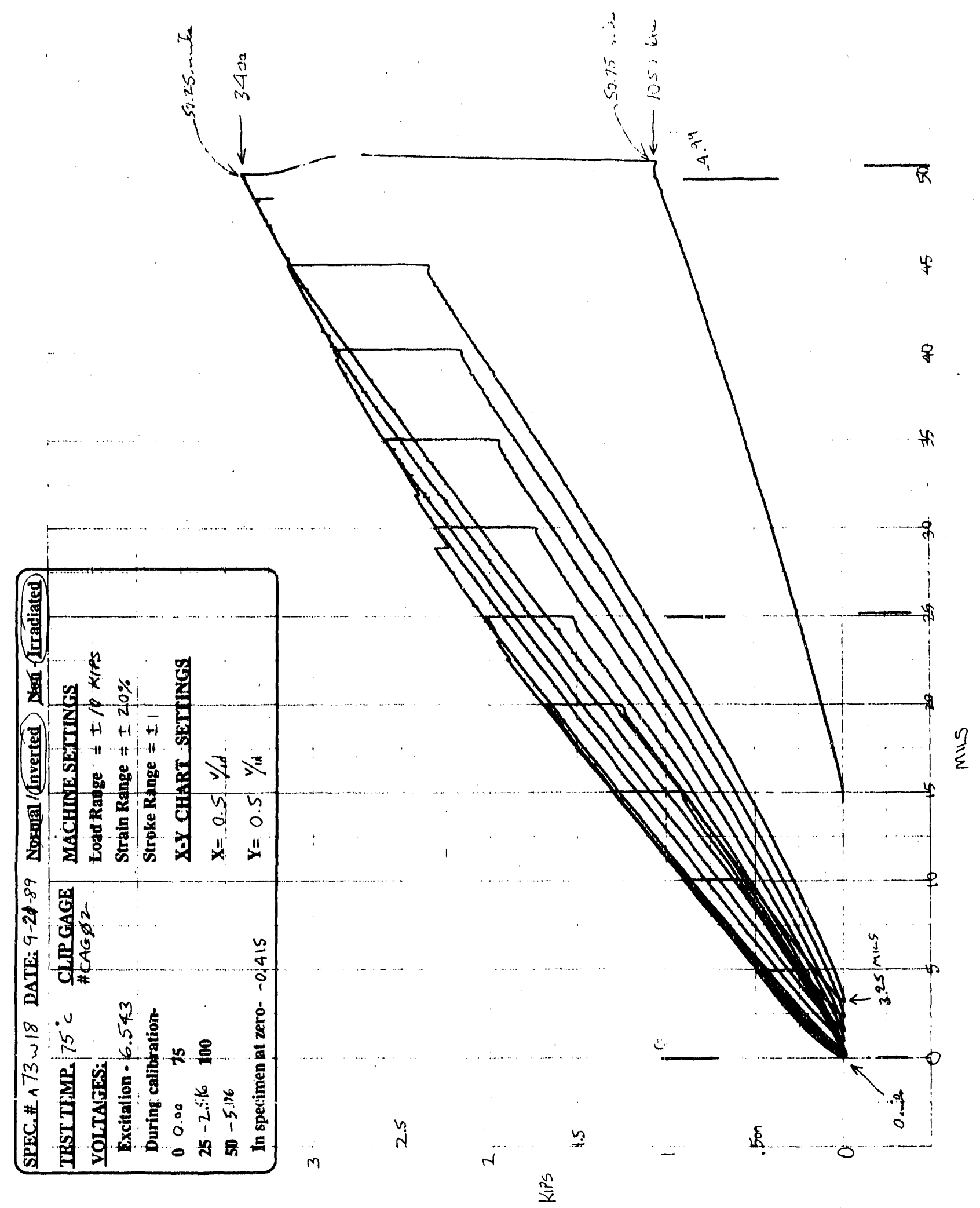




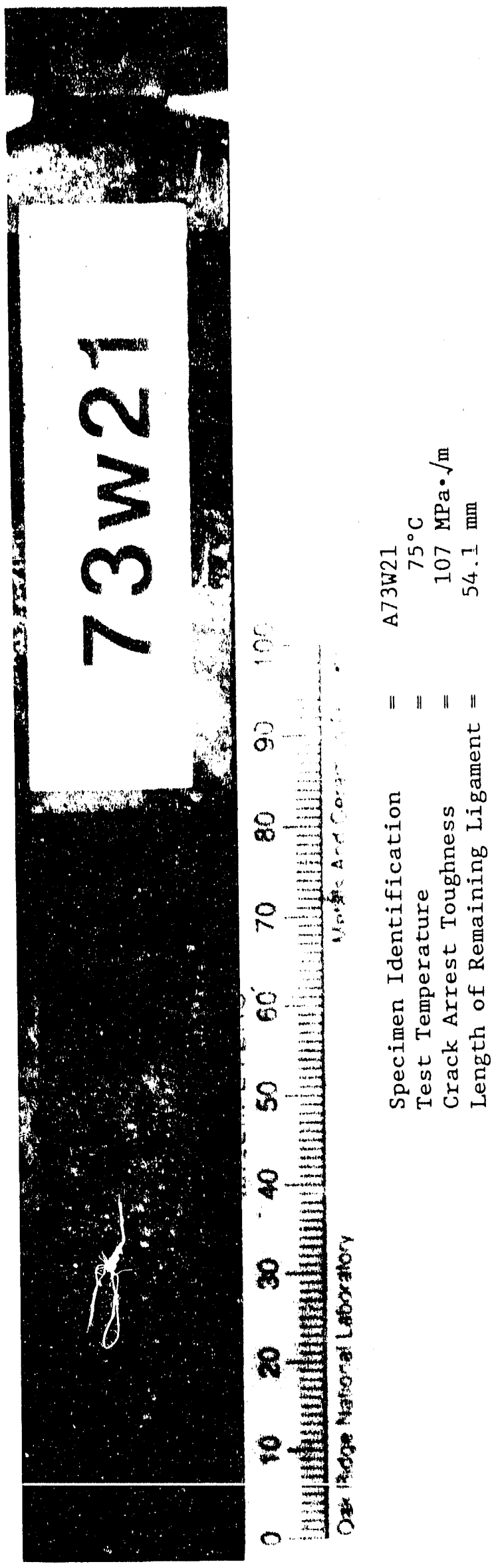




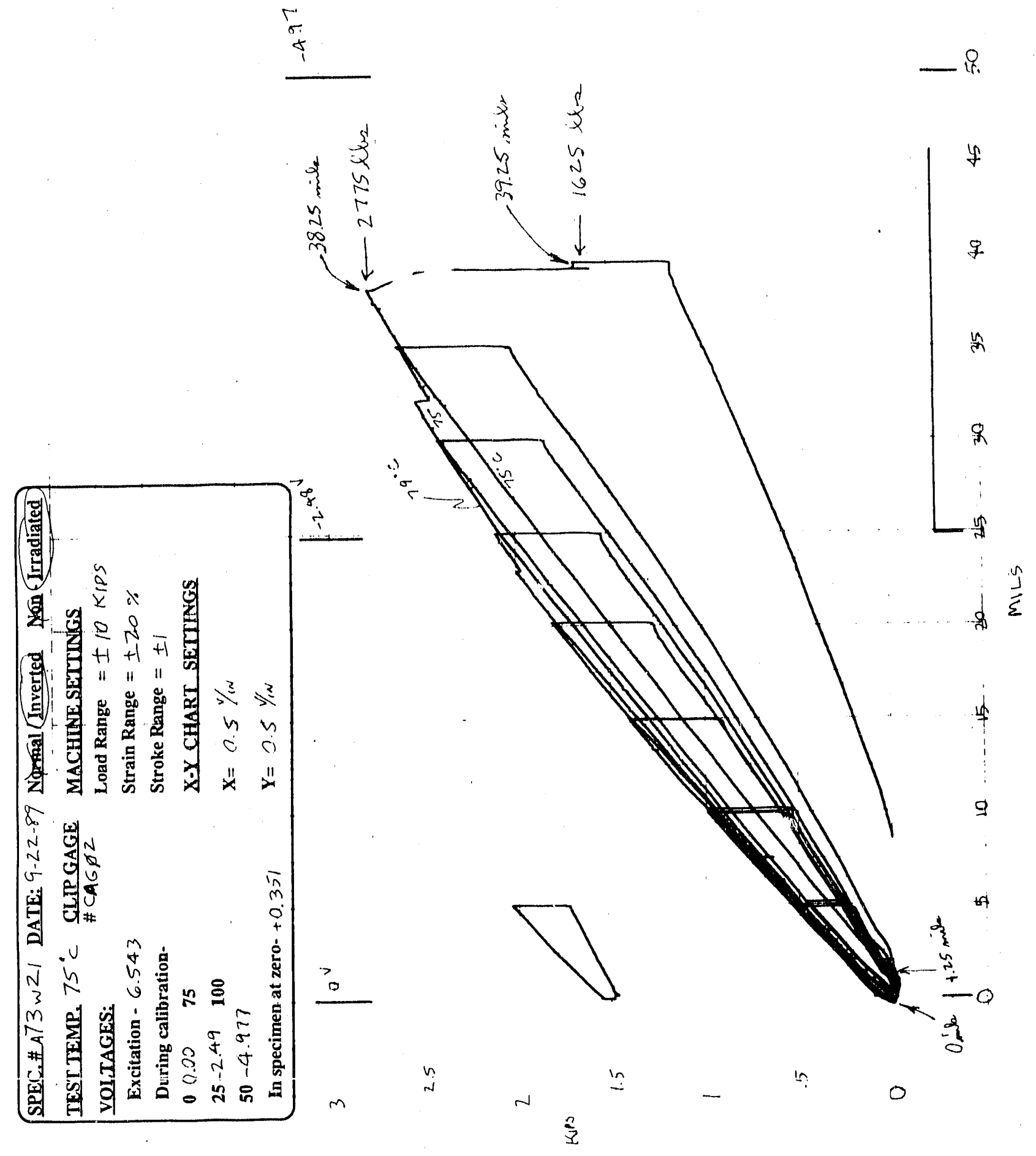




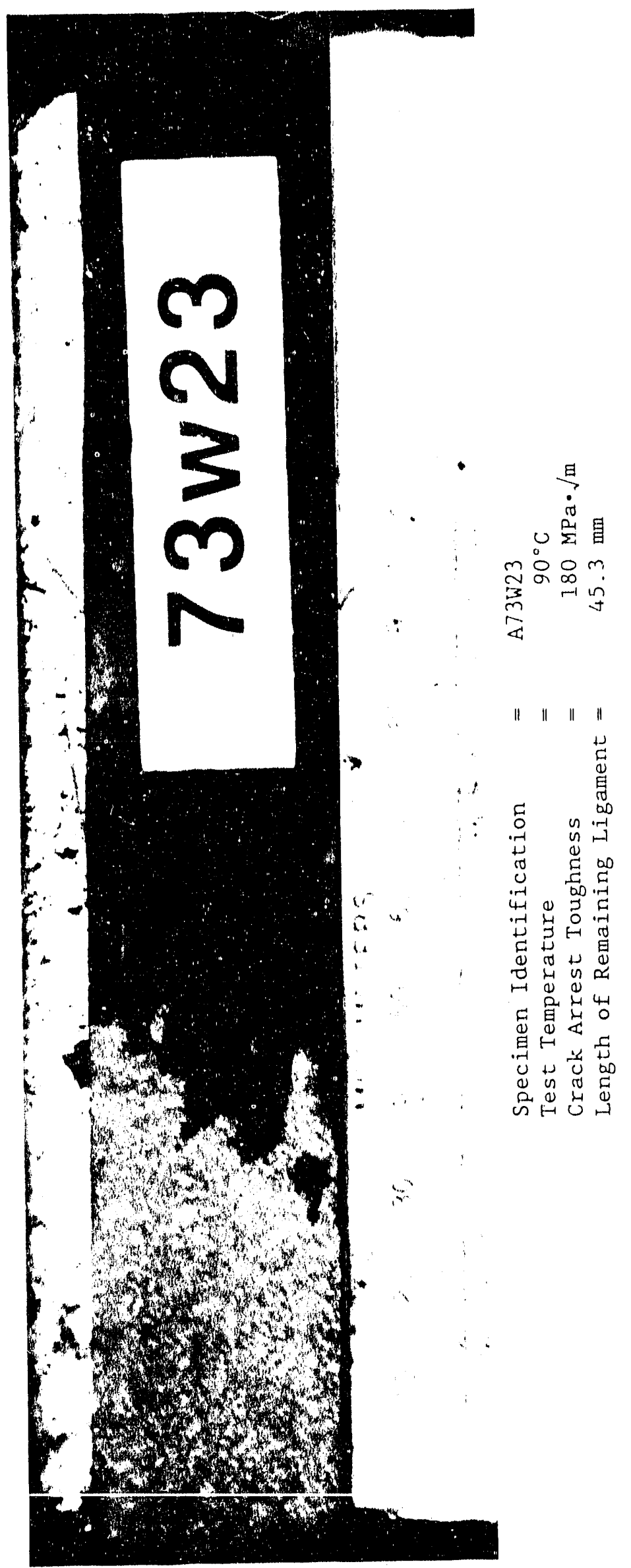




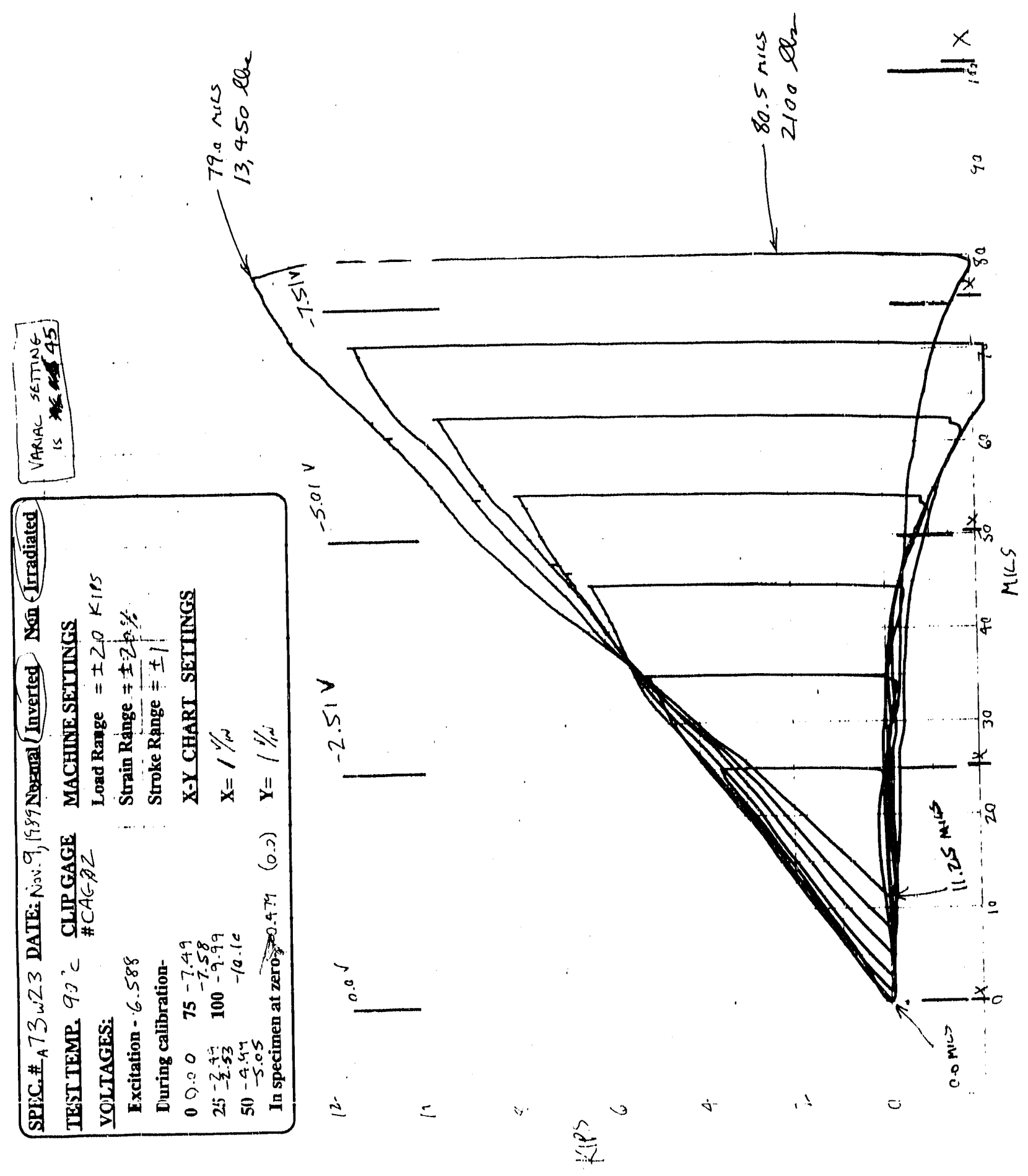




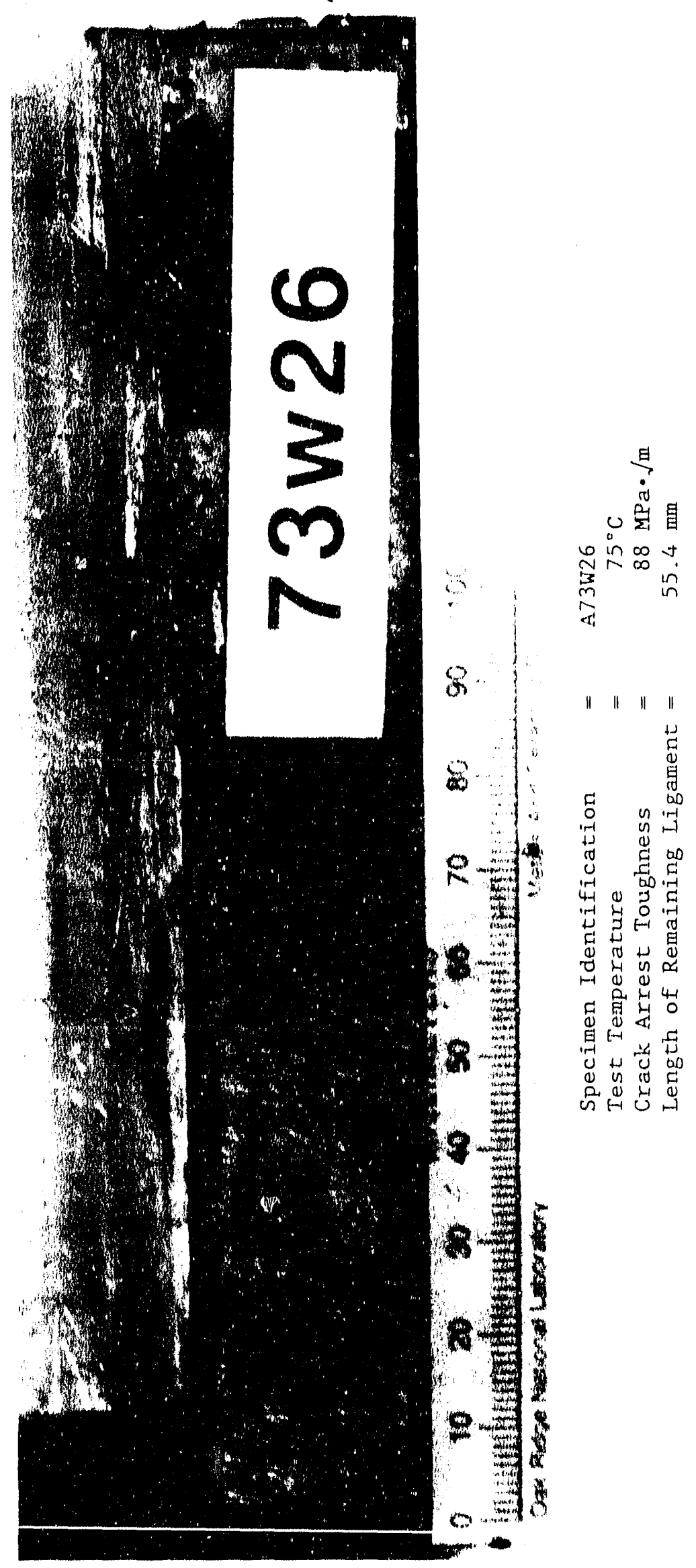



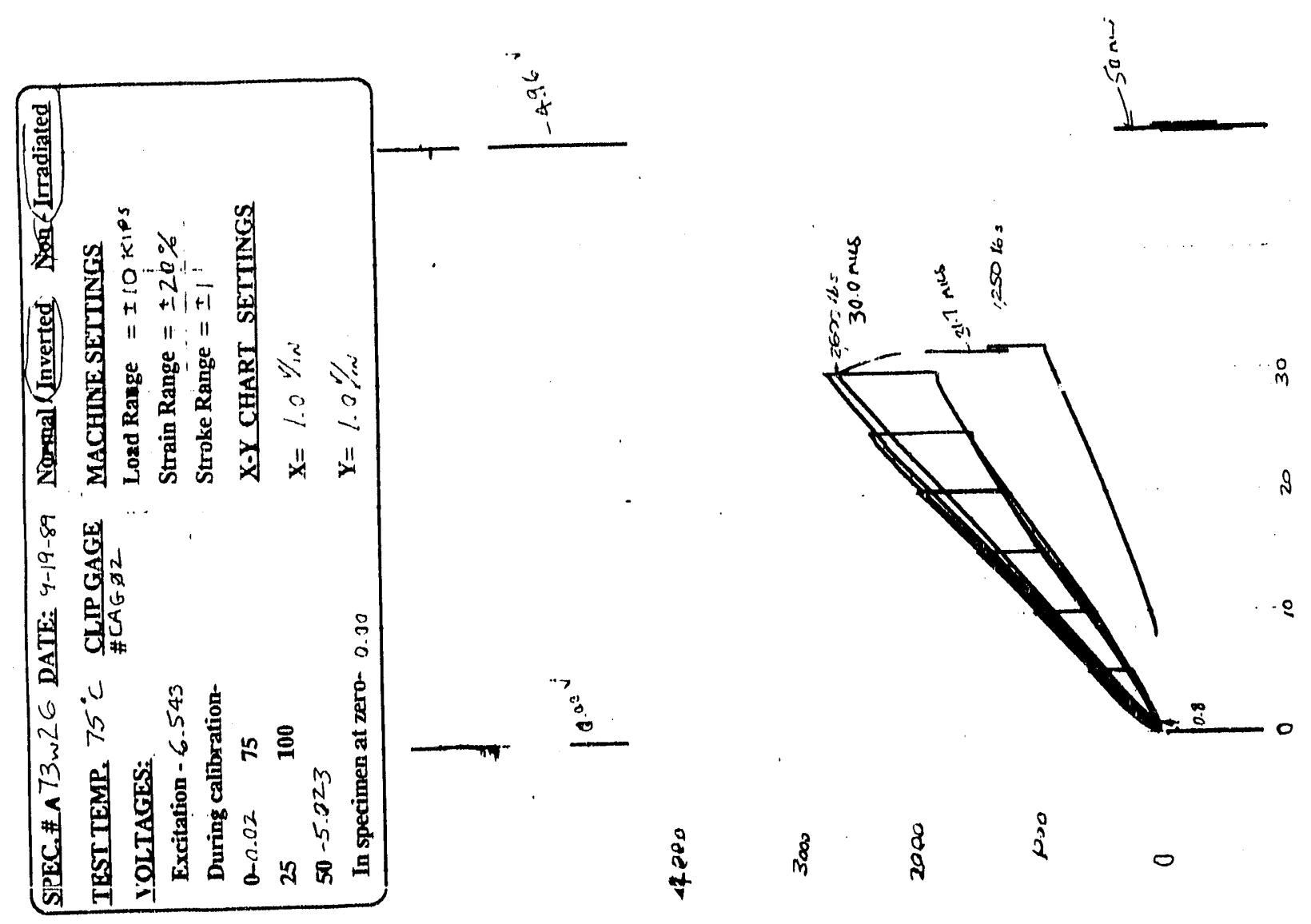


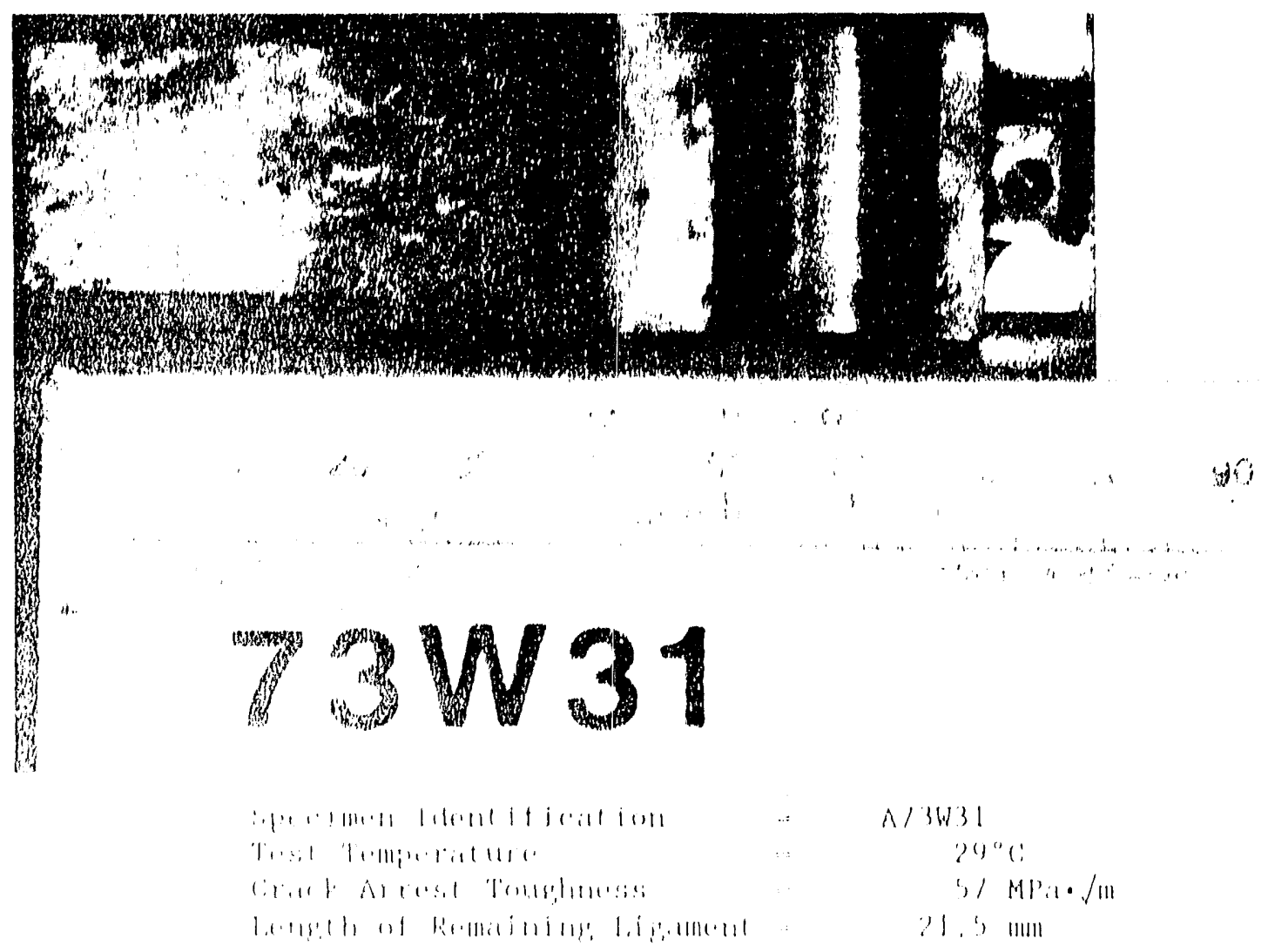




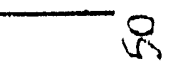

$\stackrel{n}{+}$

$\stackrel{9}{4}$

in

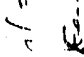

之े.

in

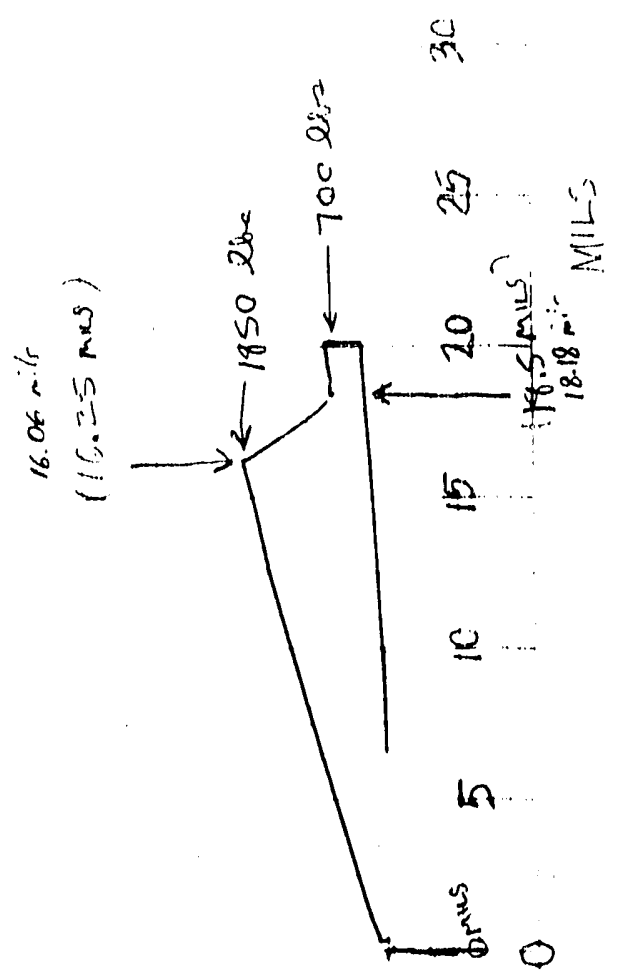

3

h?

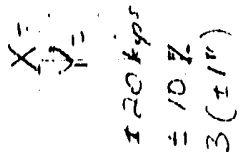

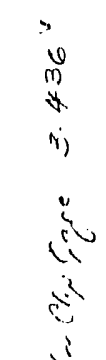

$m$
$m$
0

i)

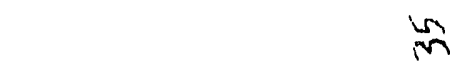

on

sin

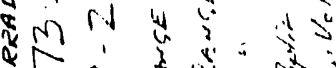

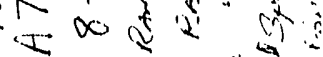

Ui

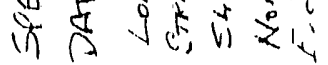

Q

$\infty$

6

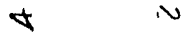




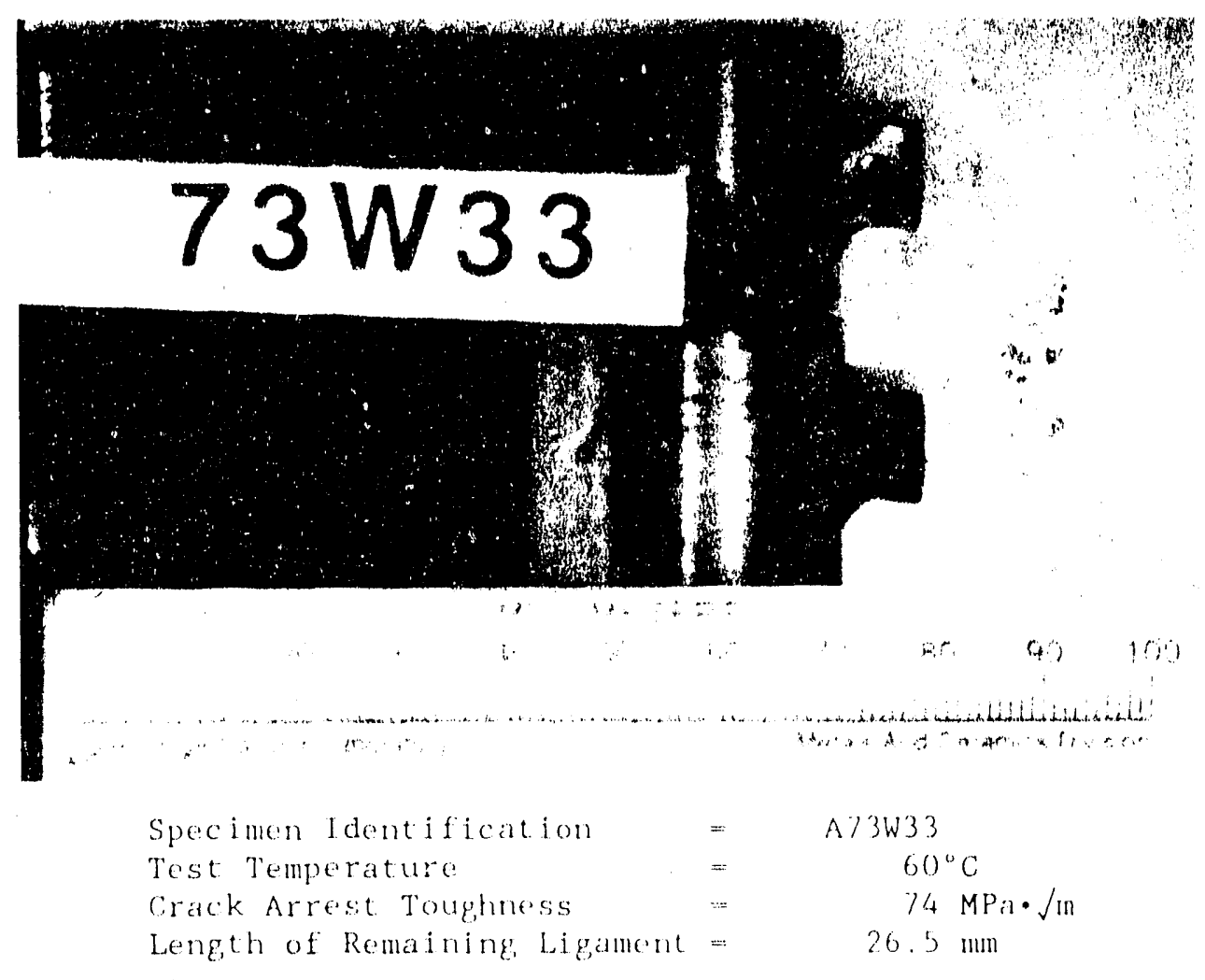


i.

4

운

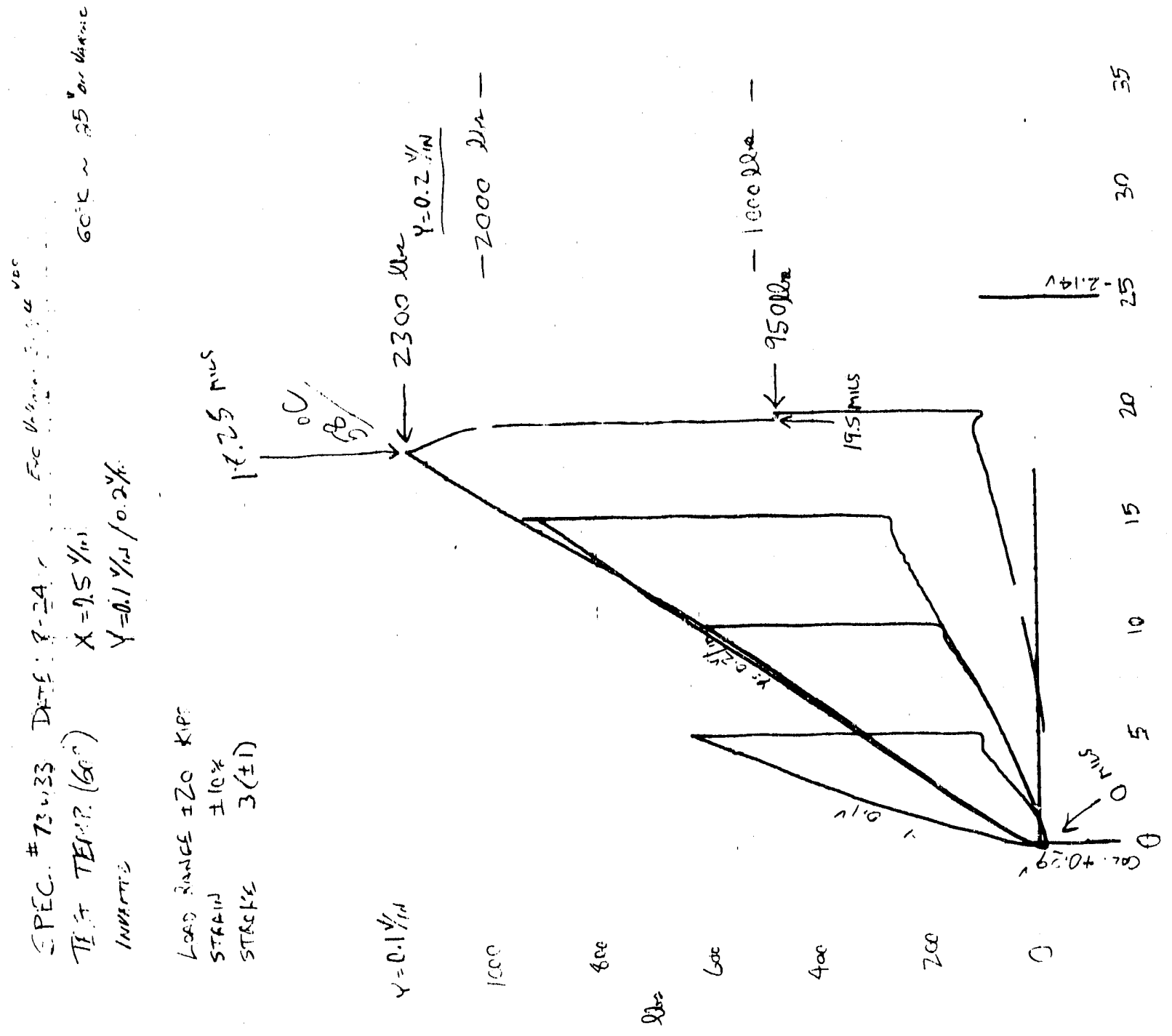




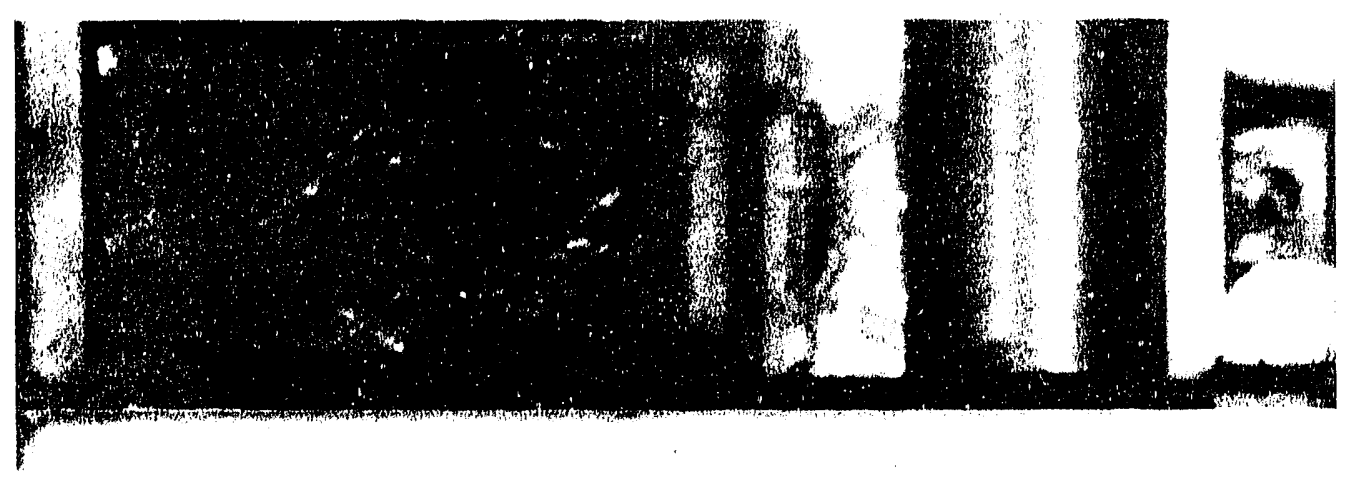

\section{$73 W 34$}

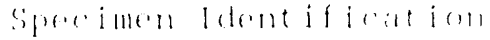

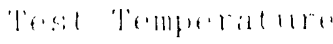

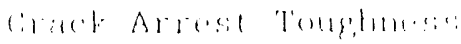

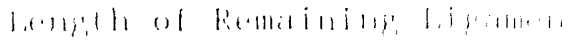

A) $: W: 14$

$91 \% 1:$

i.11 inl 19.11 


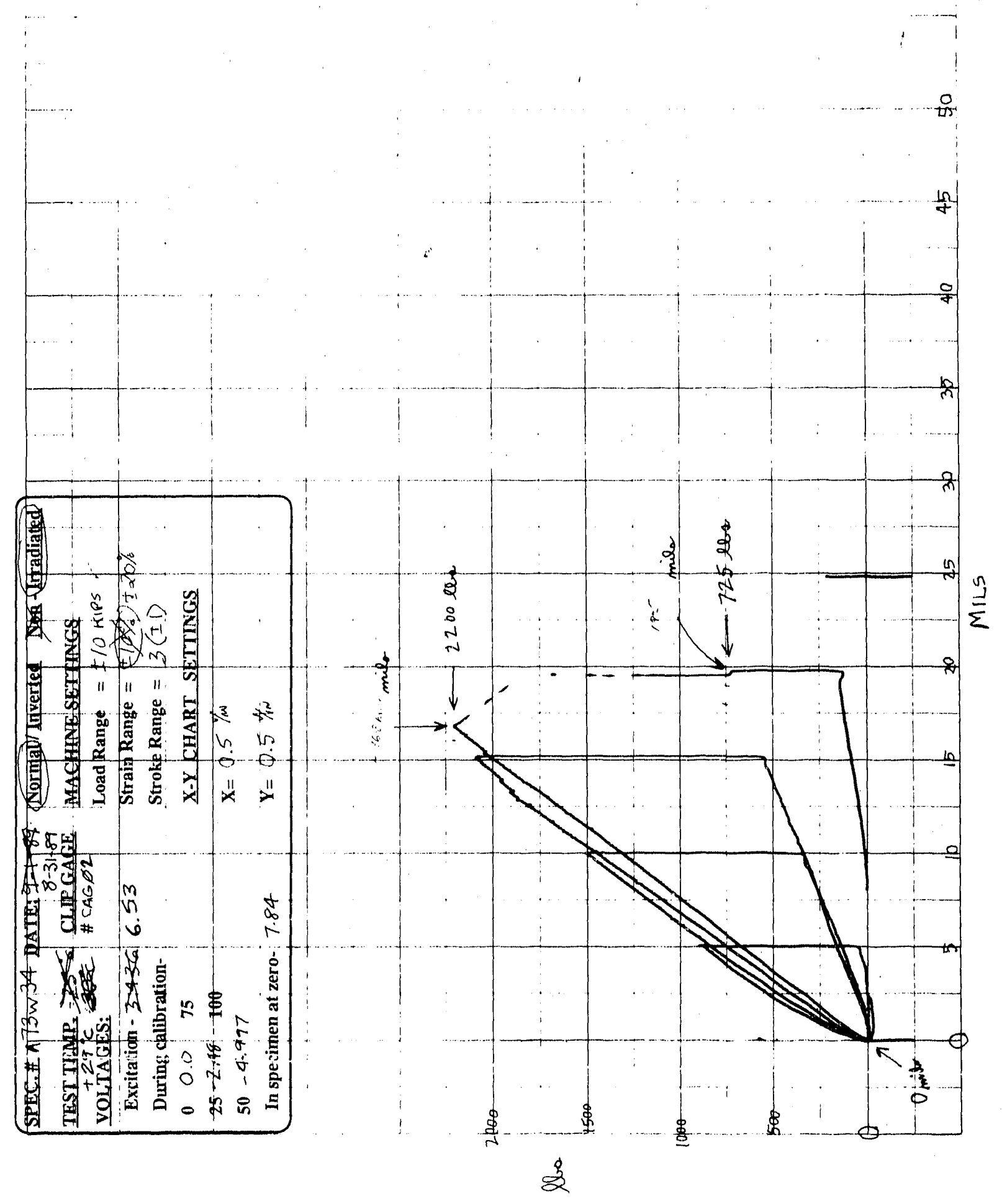




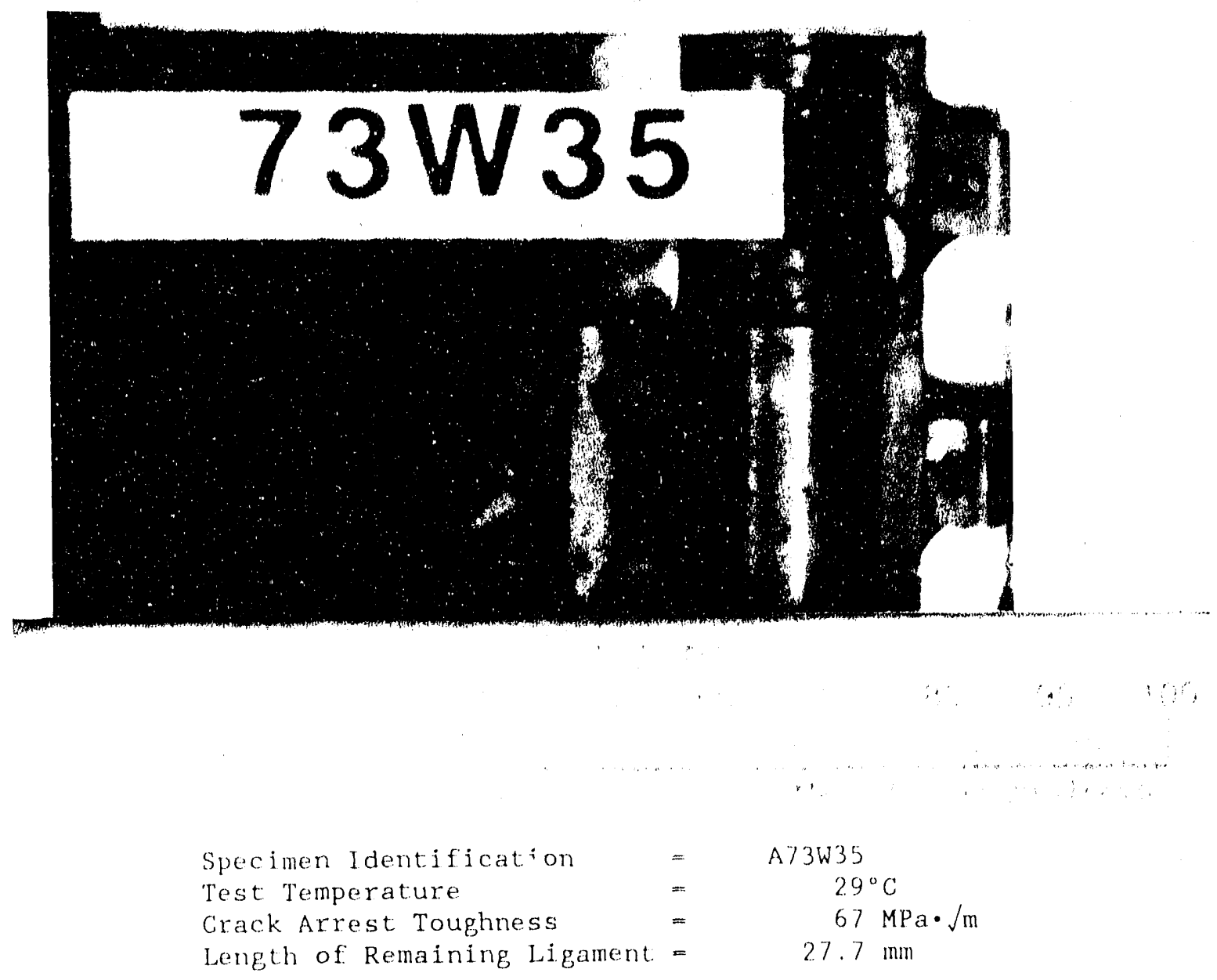


요

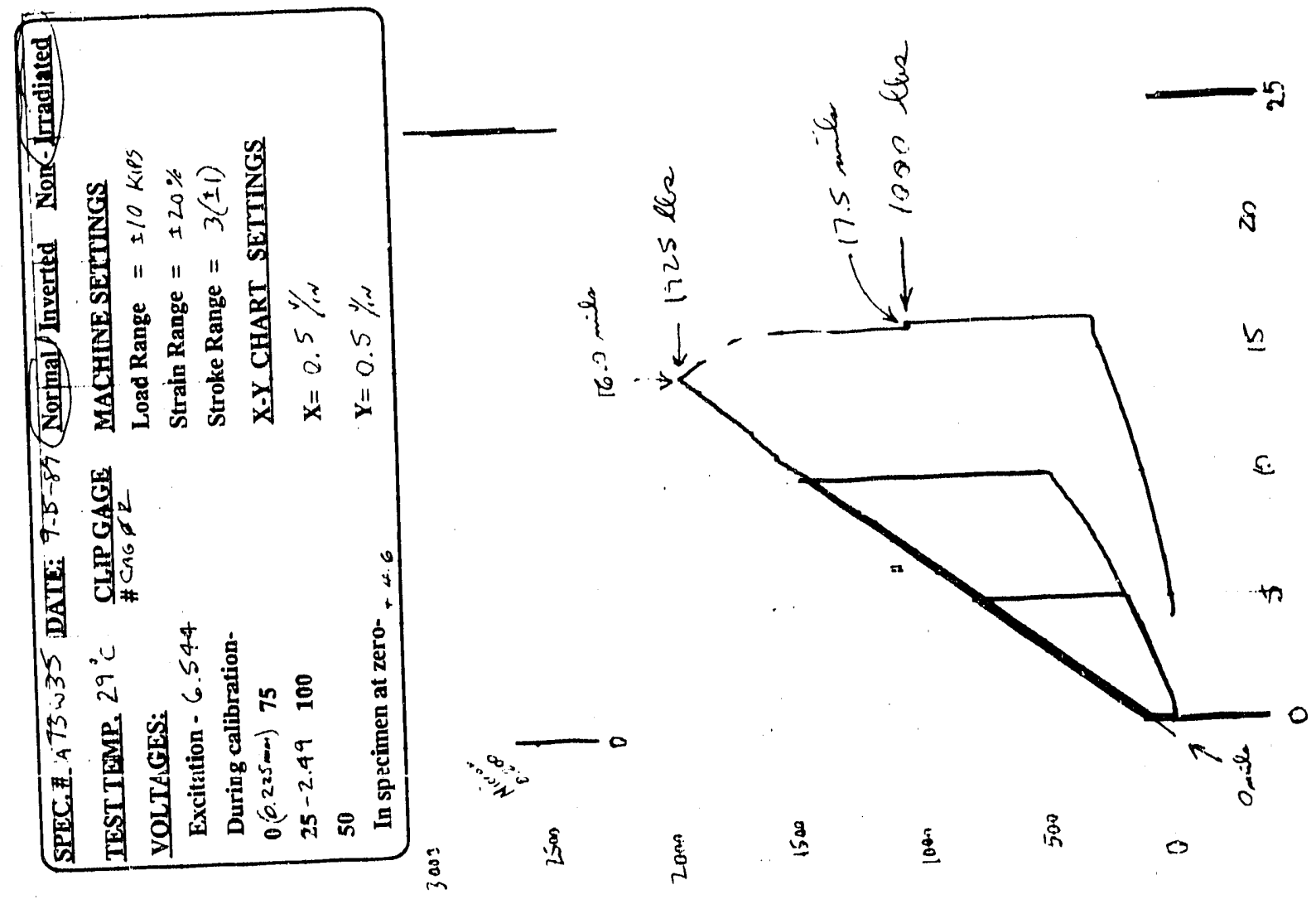




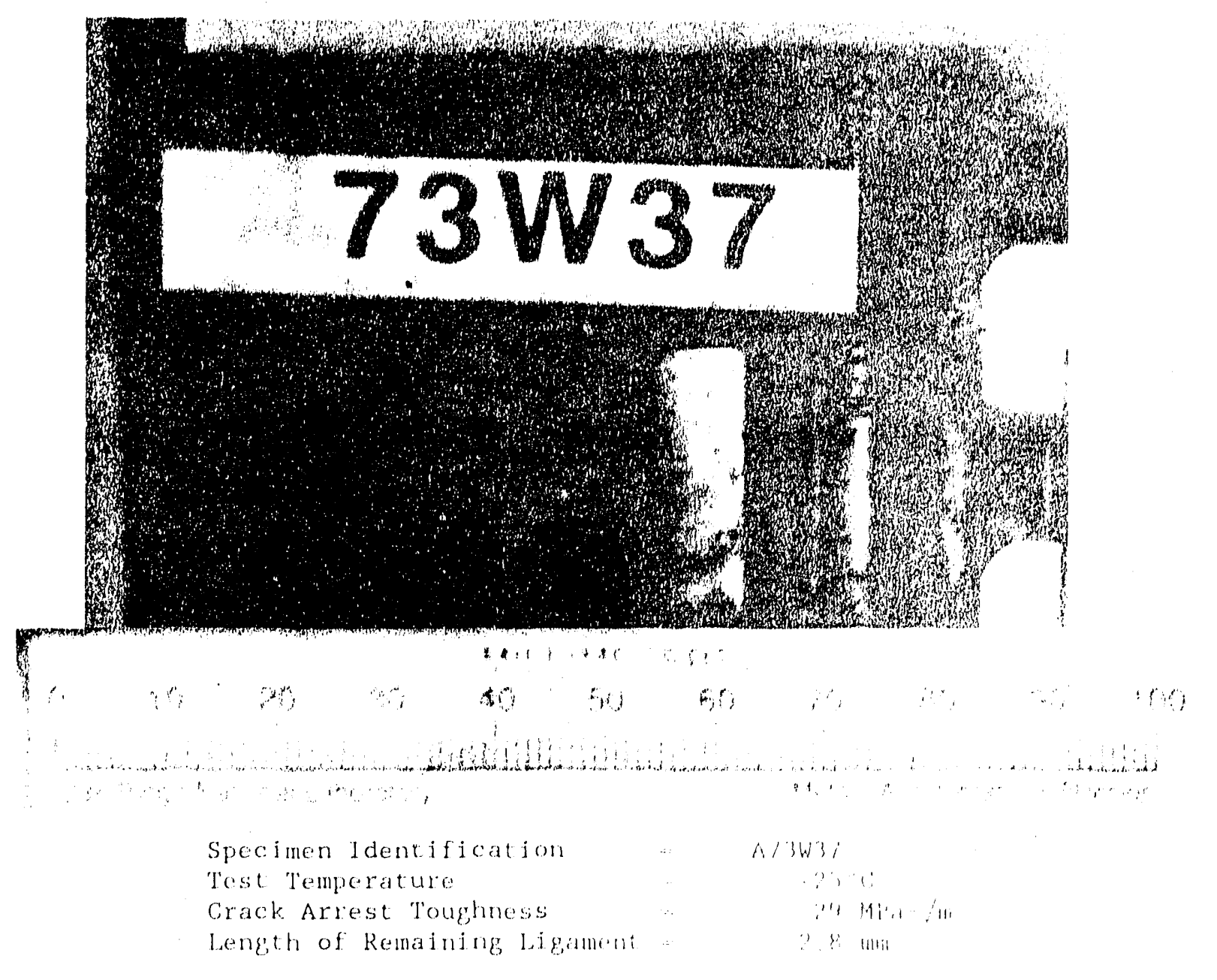



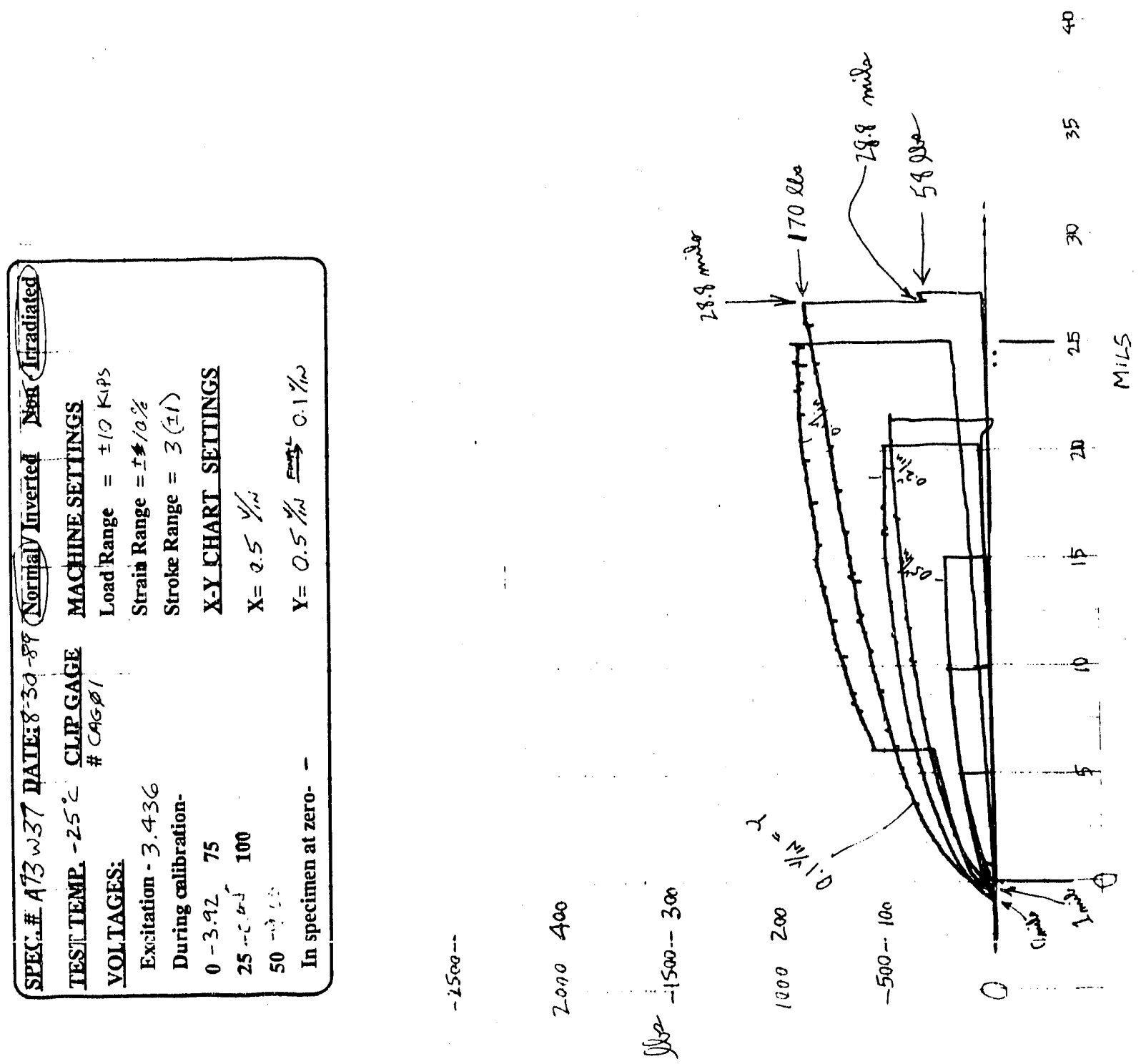


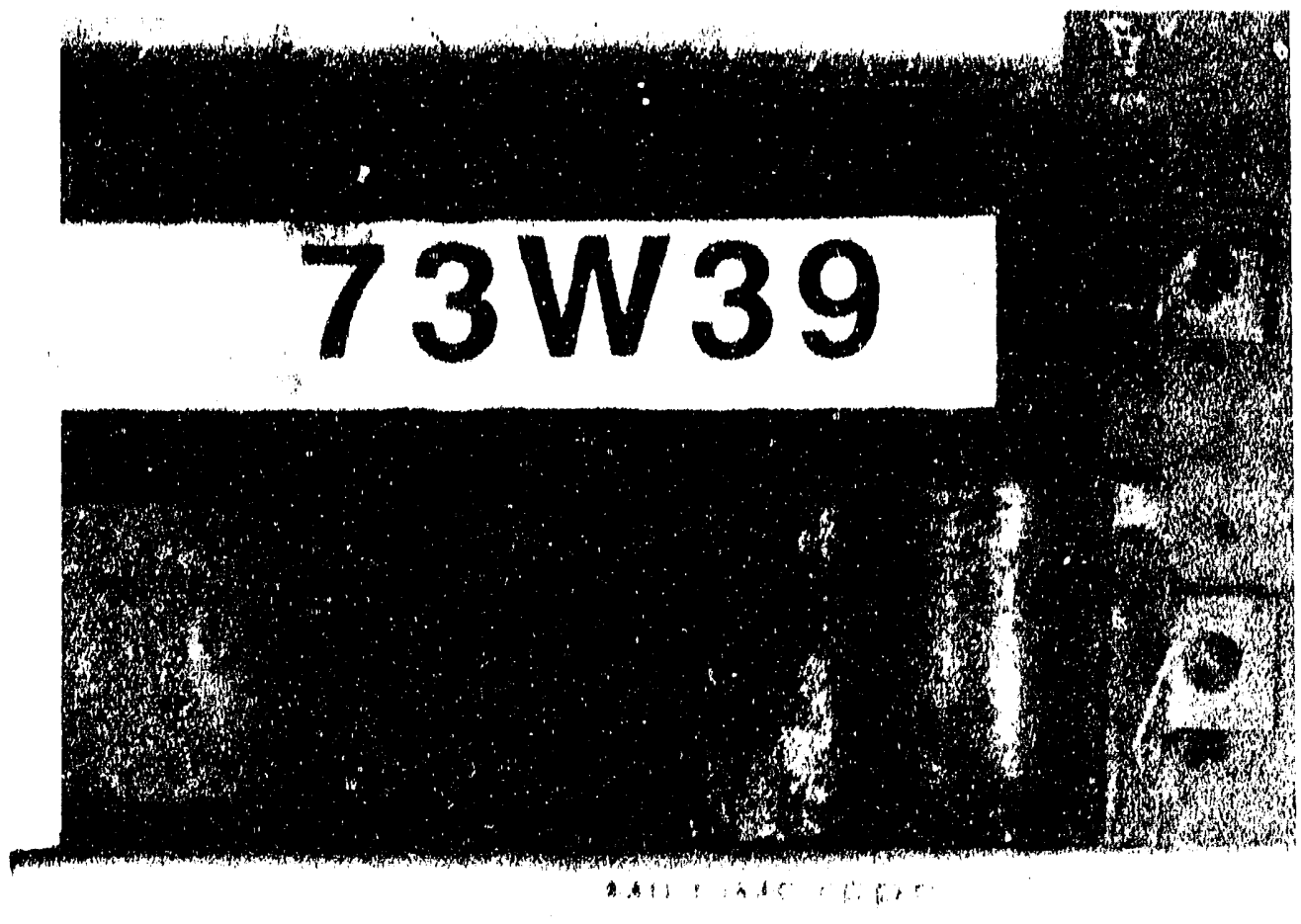

(3)

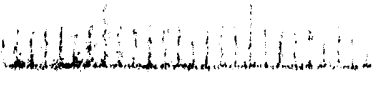

Specimen Ident if icat ion

T'est lemperature

Crack Arrest Toughmess

lang,th of Remaining, l.igrament
$B / 3 W 3$

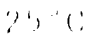

$1411^{\prime} ; 1 \cdot / m$

1/. (1 IIIII) 

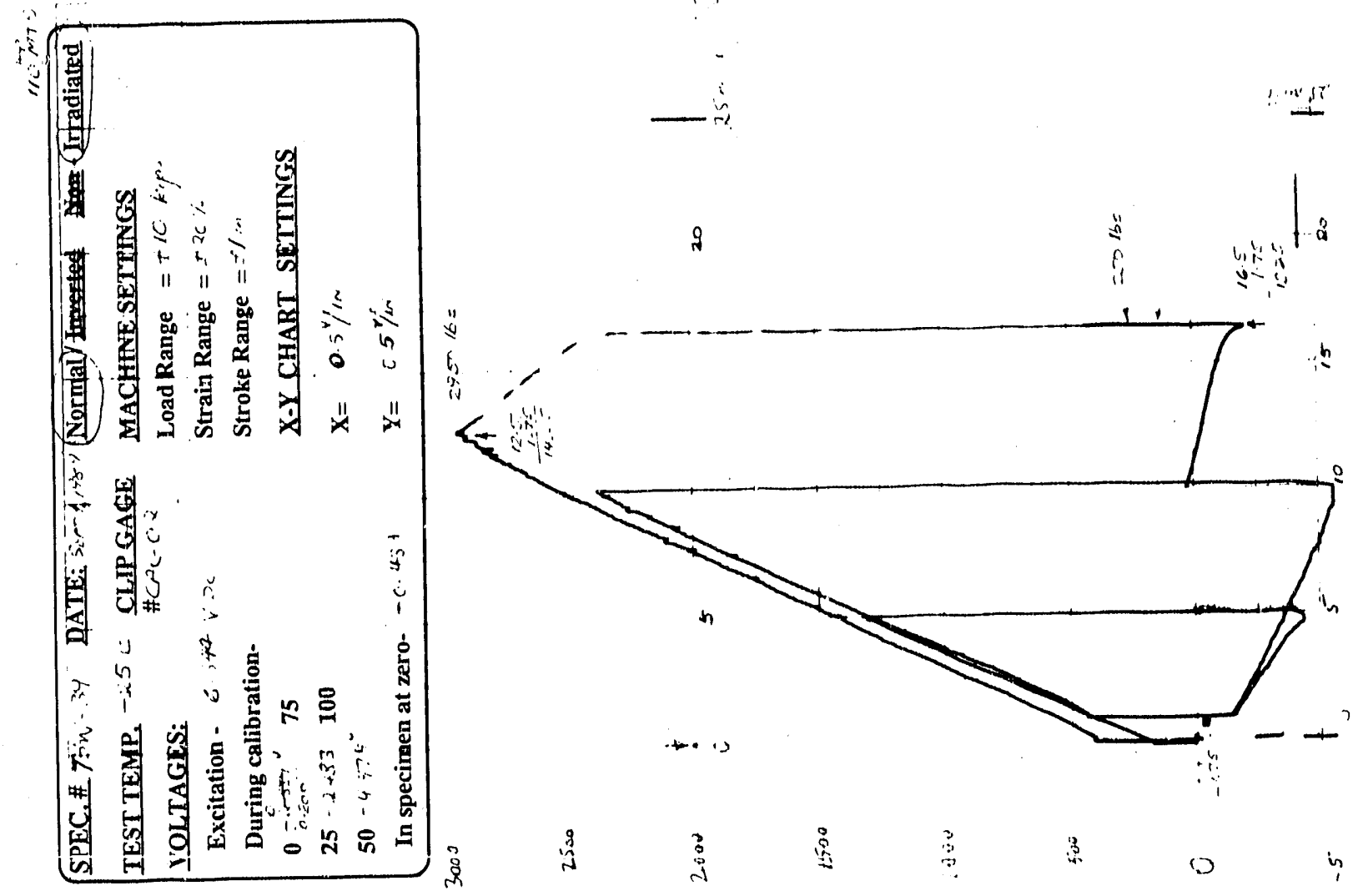


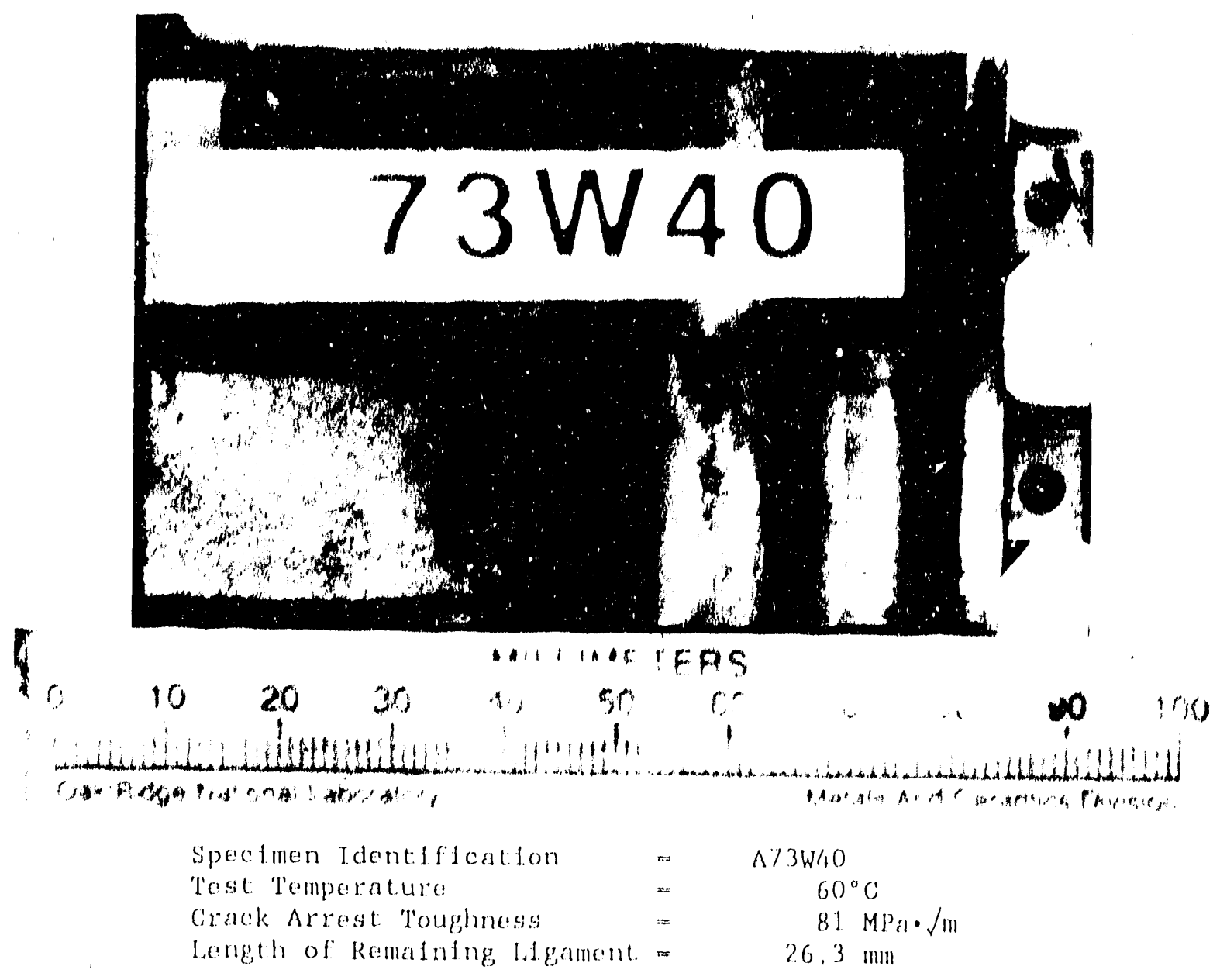




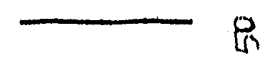

$p$

4

f

네
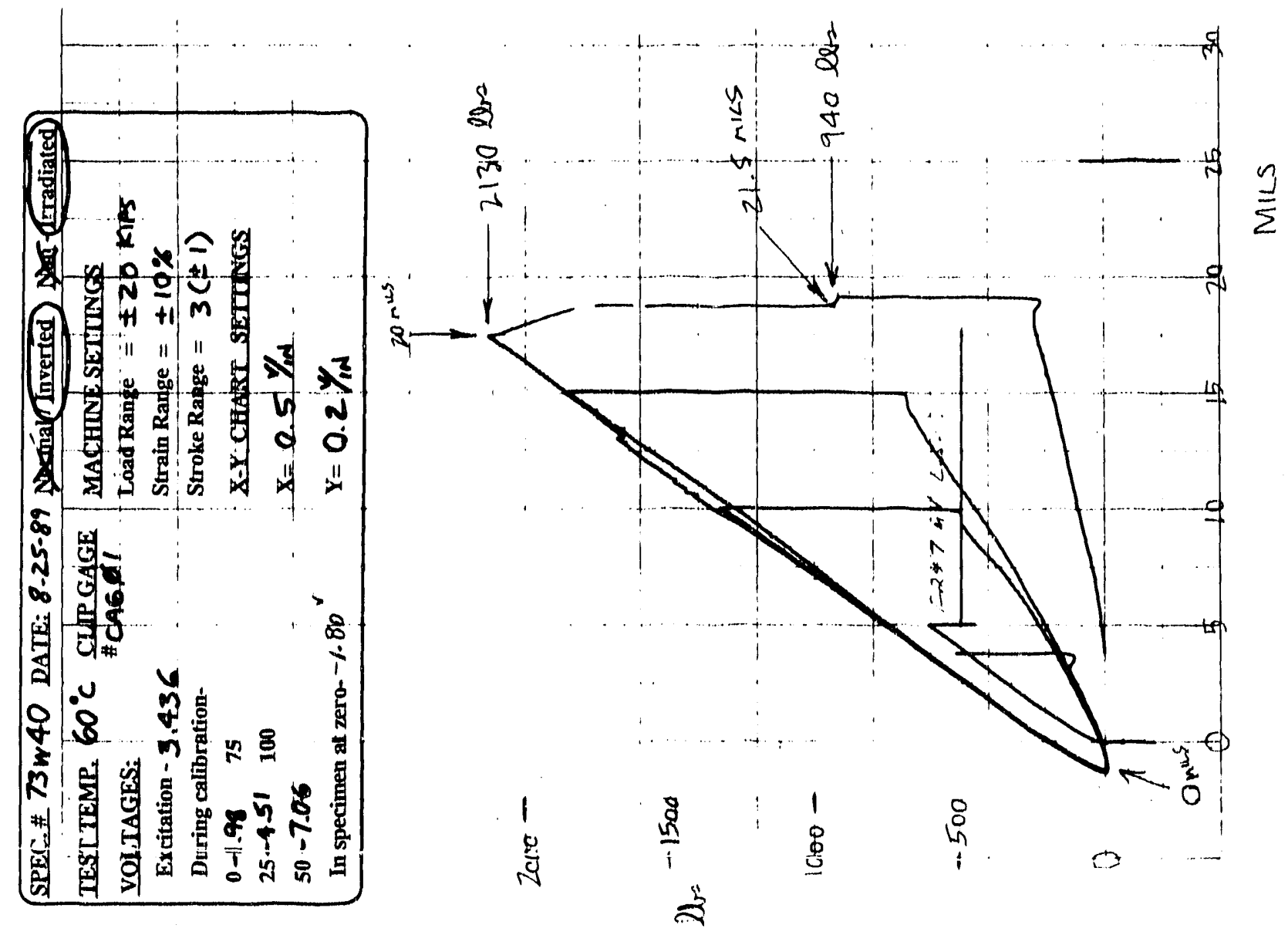


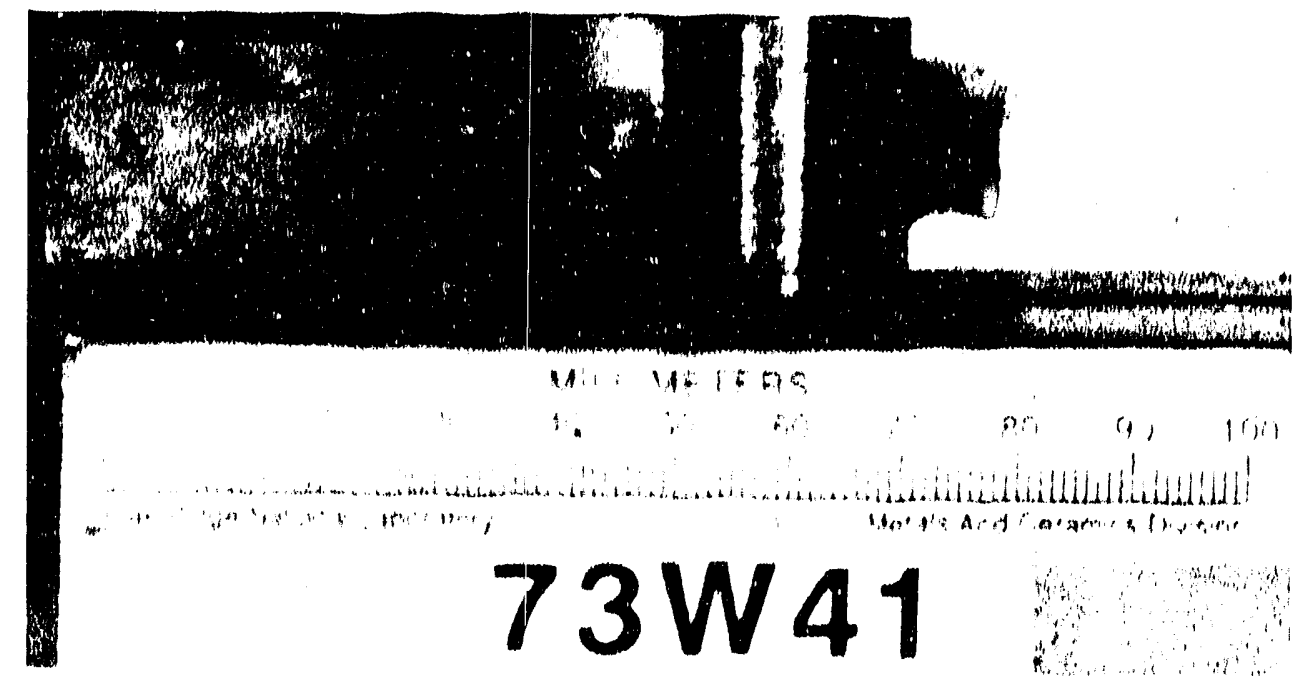

Spectanen ldent fficallon f'rest l'emperature

$\Lambda / 3 W / 4$

crack Arrest toughlonesses

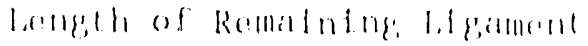
6()$^{\circ} \mathrm{C}:$ 19 $\mathrm{MP}^{\mathrm{a}} \cdot \mathrm{J} \cdot \mathrm{II}$ $30.9 \mathrm{mIn}$ 


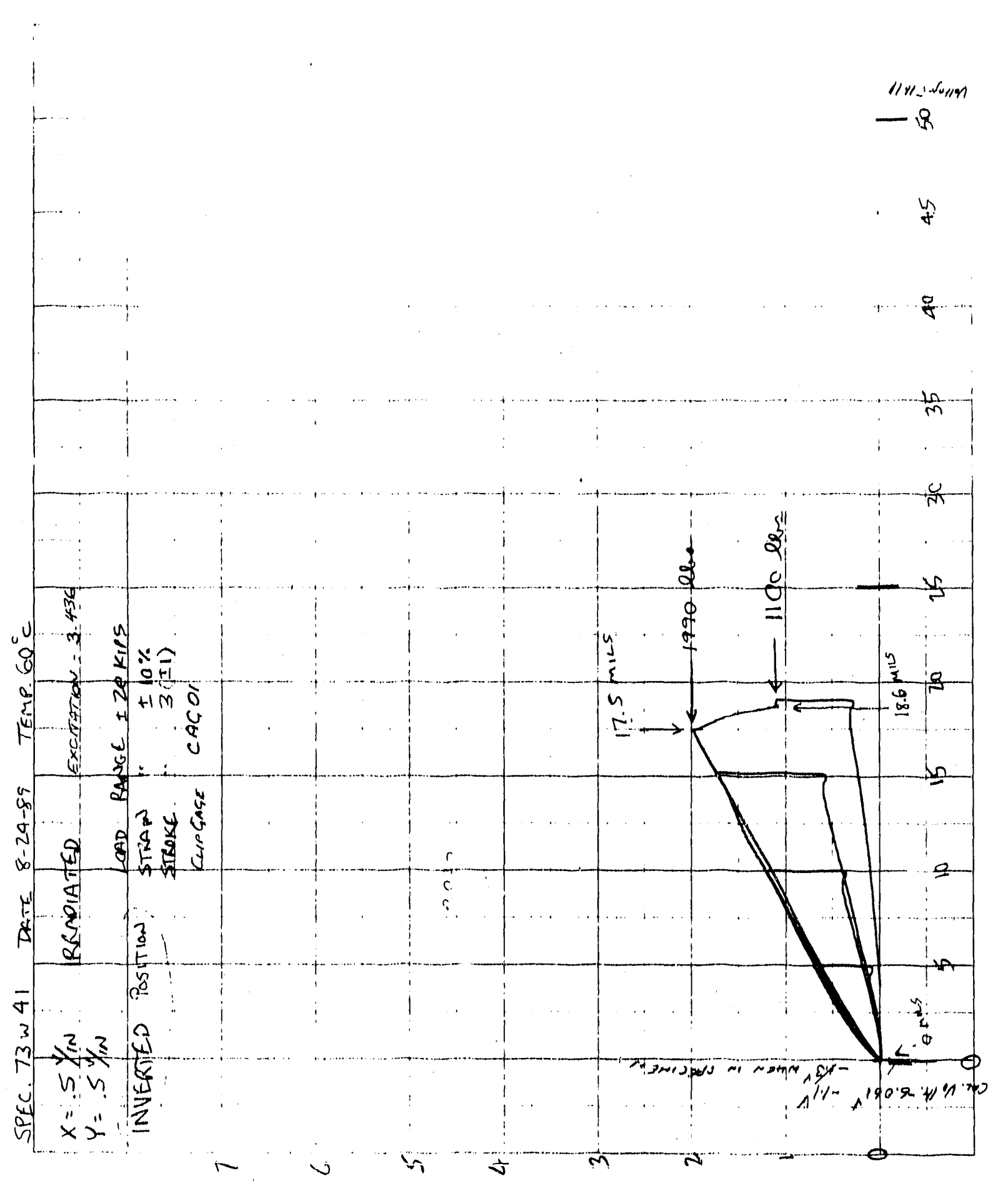




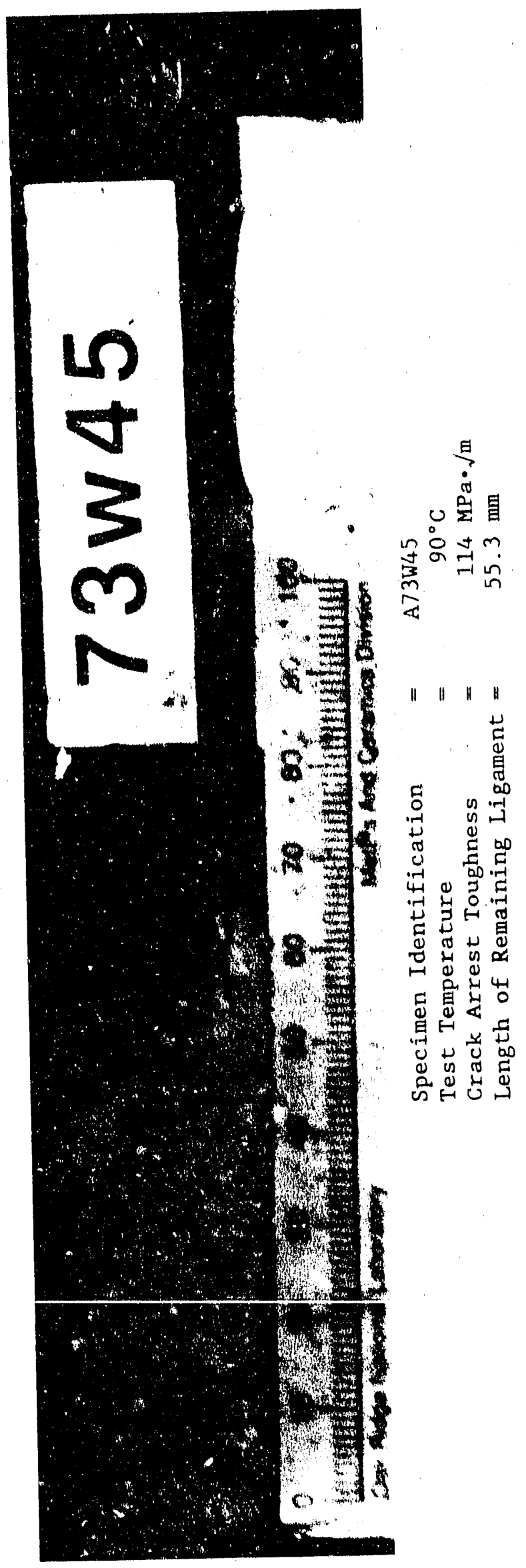




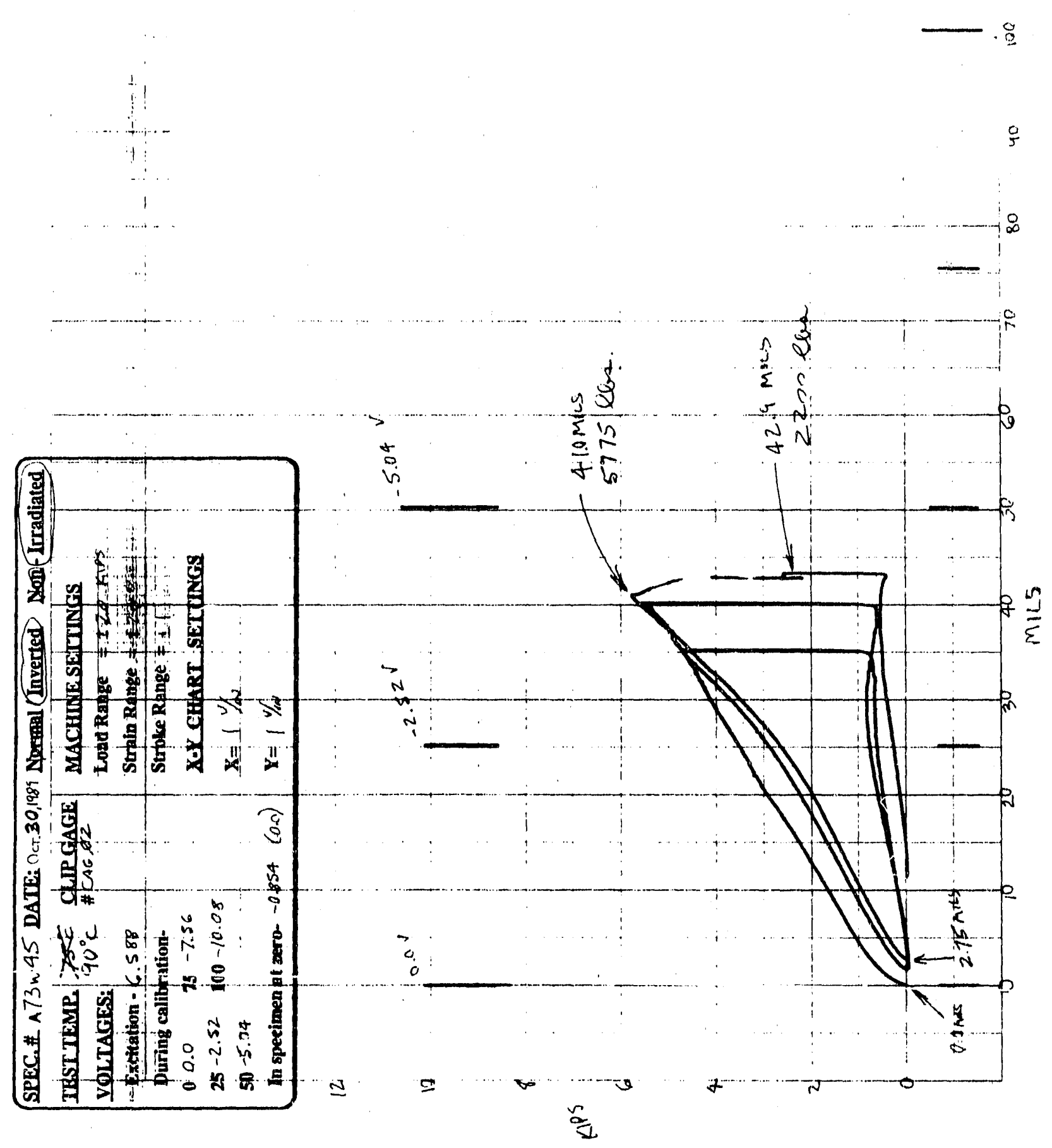




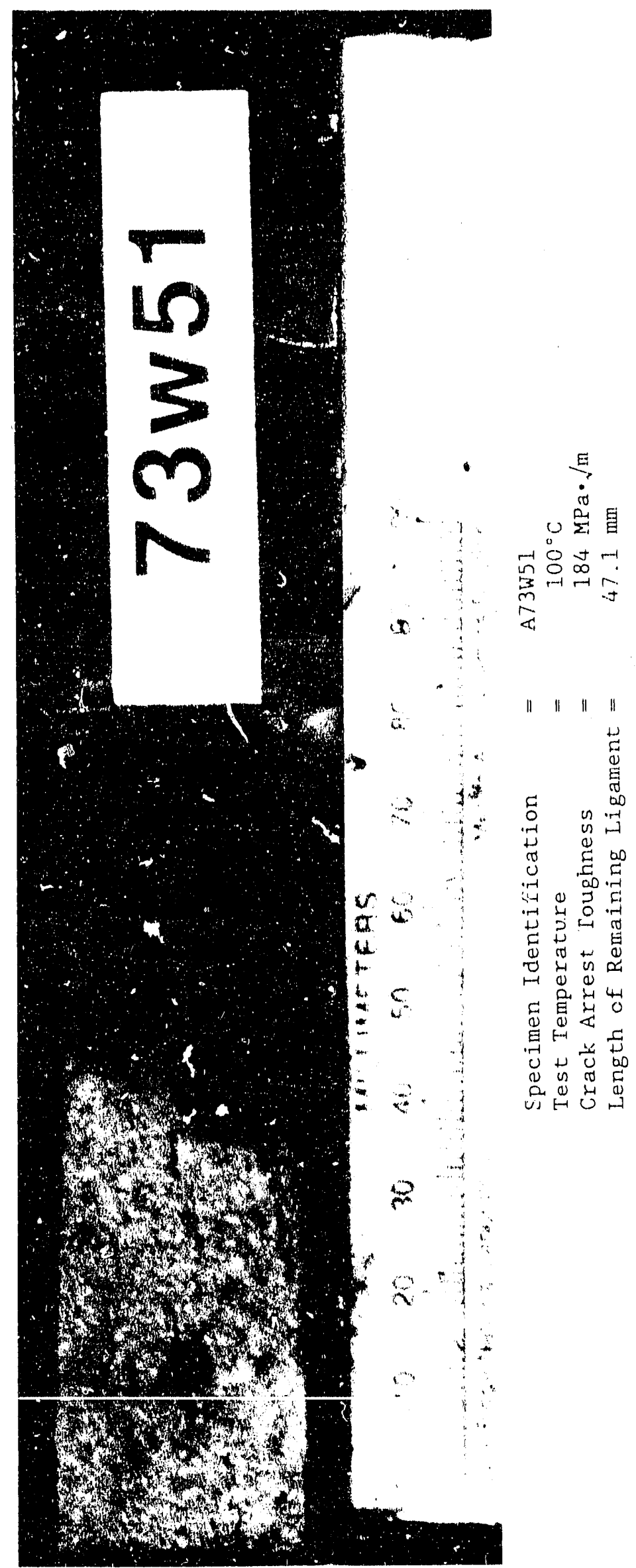




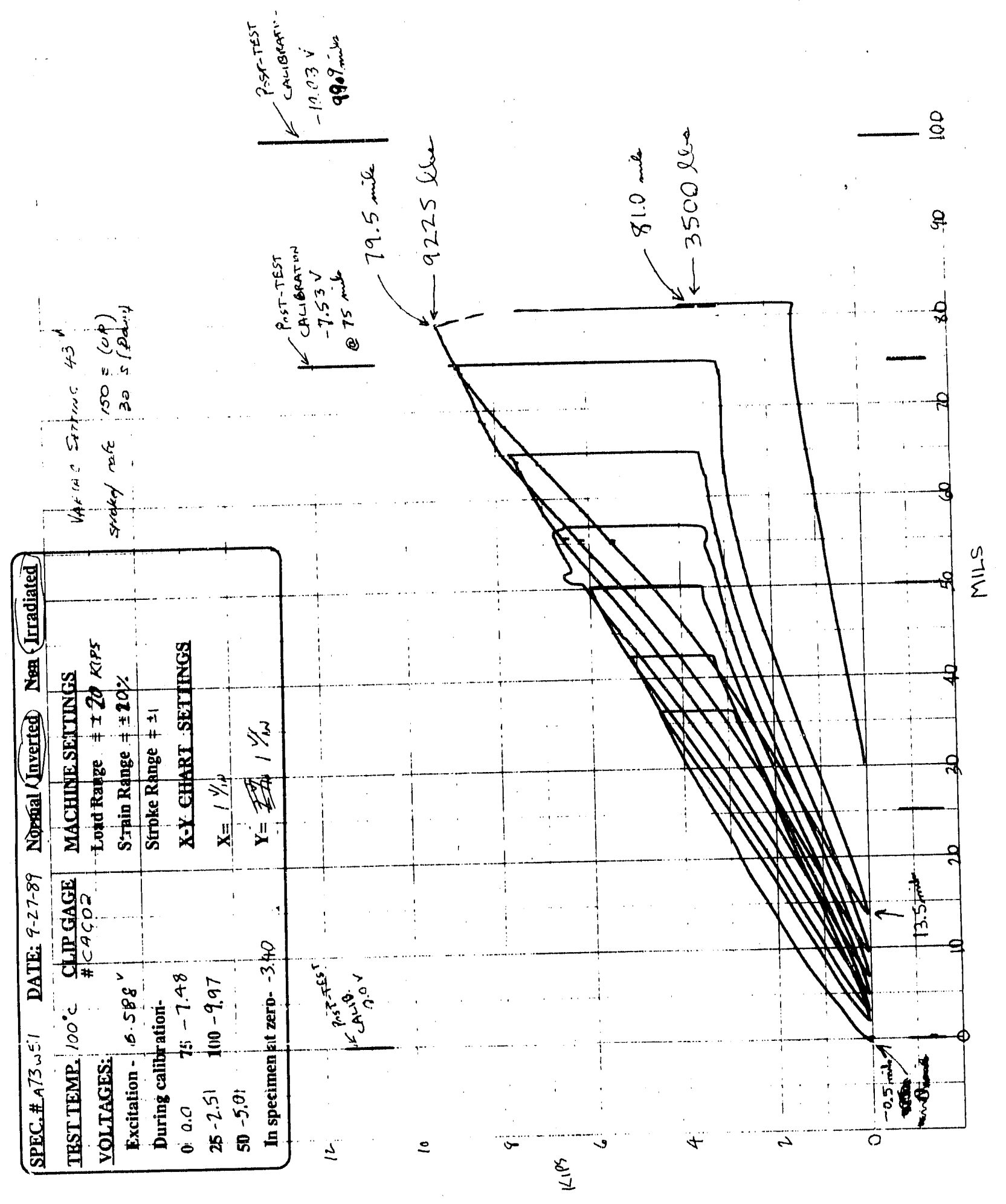



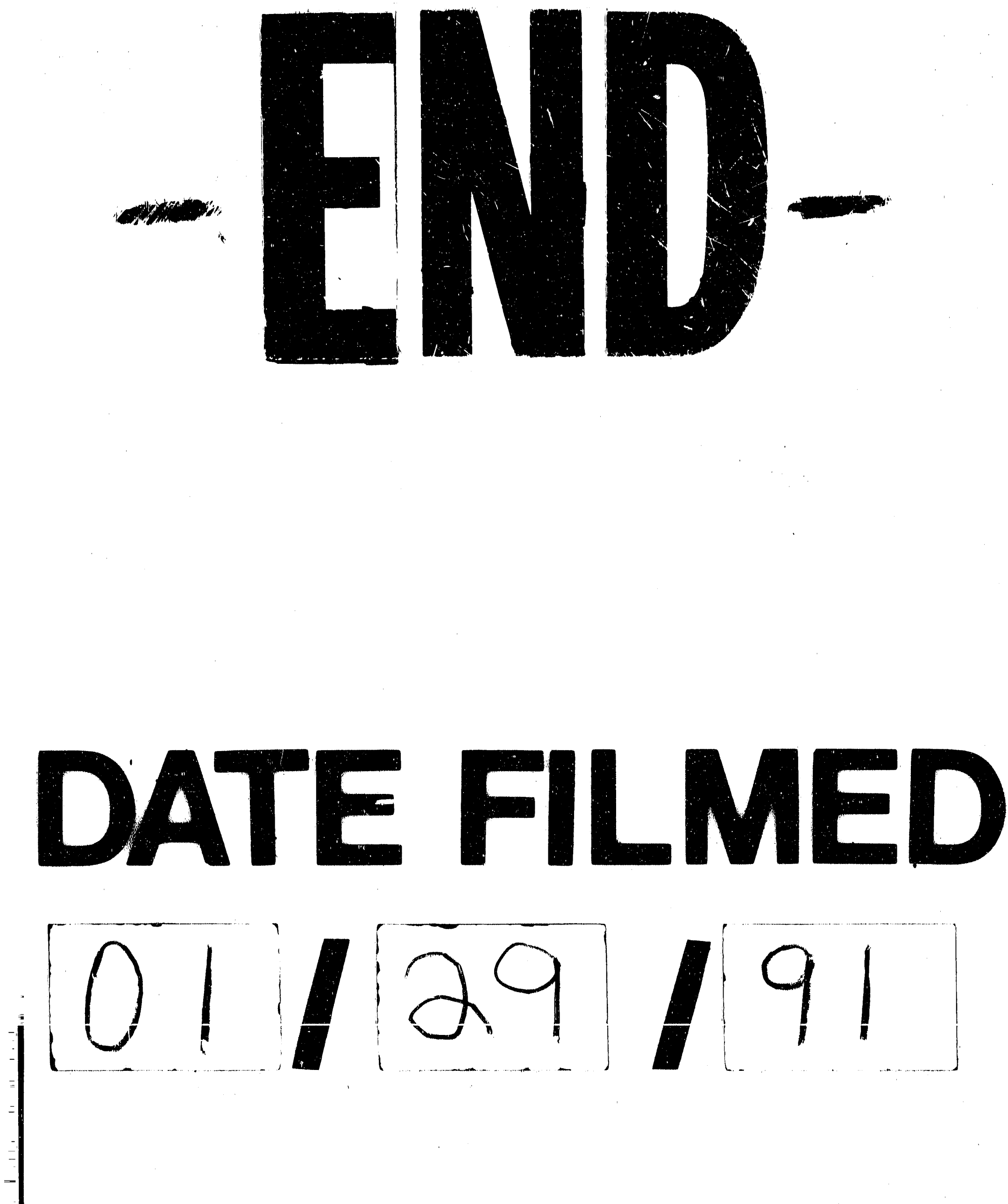
